CARLA CARVALHO ALVES

\title{
FIGURAÇÕES DO MOURO NA LITERATURA PORTUGUESA: O LADO ERRADO DO MARENOSTRO?
}

Tese apresentada para defesa de Doutorado na área de Literatura Portuguesa

Departamento: Letras Clássicas e Vernáculas da Faculdade de Filosofia, Letras e Ciências Humanas da Universidade de São Paulo

Orientador: Paulo Motta Oliveira 
Carla Carvalho Alves

Título: Figurações do mouro na Literatura Portuguesa: o lado errado do marenostro?

Tese apresentada para defesa de Doutorado na área de Literatura Portuguesa Departamento: Letras Clássicas e Vernáculas da Faculdade de Filosofia, Letras e Ciências Humanas da Universidade de São Paulo

Paulo Fernando Motta Oliveira

São Paulo, novembro de 2010. 
Aos meus pais:

Maria Conceição Alves e Carlos Alberto Andrade Alves, pelo amor e apoio incondicionais

Às minhas irmãs:

Andréa e Vera, pela amizade e carinho constantes 
Agradeço imensamente ao prof. Paulo Motta pela presença sempre incentivadora, sábia, tranquila e amiga.

Agradeço, também, outros professores que estiveram presentes em momentos importantes da elaboração dessa tese: Hélder Garmes, Eduardo Vieira Martins, Fátima Bueno, Ernesto Rodrigues.

Meu agradecimento também à profa. Tereza Virgínia, por todos os ensinamentos e incentivo que me ajudaram a chegar até aqui.

Muito, muito, muito obrigada aos meus irmãos, cunhados, cunhadas e sobrinhos queridíssimos, que entenderam minha ausência e me apoiaram tanto durante todo o processo de escrita dessa tese!

E aos amigos do coração, por toda a disponibilidade e carinho: Karla Cipreste, Susana Ventura, Regina Kawamura, Raquel Madanelo e Frederico, Juliana Santos, Adriano Bitencourt, Letícia Taitson, Tárik, Luciene Pavanello, Ana Luísa, Miúcha, Débora Leite, Fátima, Paulo,Antonio Augusto, Eduardo, Alberto, Cibele Lopresti, Fernanda Rmano, Vander, Daiane e Giu, Hélder, Drica, Edineusa, Ju, Marcelo, Ronaldo, Luciene Oliveira. 
Agradeço à FAPESP pela concessão da bolsa de estudo, mantida ao longo de boa parte do doutoramento.

Agradeço também à CAPES pela concessão da bolsa de estudo referente aos últimos meses de realização do doutorado. 
O bárbaro não está no exterior, mas é interno ao movimento de criação e transmissão da cultura, é o que causa horror àquele que contempla o cortejo triunfal dos vencedores pisoteando os corpos dos vencidos e conhece o preço da infâmia de cada monumento da civilização. (Marilena Chaui) 


\section{Resumo}

Percebendo a grande importância do elemento mouro na cultura portuguesa e destacando, ainda, a significância de se introduzir essa alteridade cultural e religiosa para se refletir sobre a imanência cultural, buscamos, nessa tese, analisar as diversas figurações dos mouros em obras literárias canônicas. Abarcamos, para isso, textos ficcionais de cunho histórico, centrando a atenção na obra literária de Alexandre Herculano, mas considerando, também, a origem lendária de tal tema e algumas de suas incidências mais significativas na contemporaneidade. 


\begin{abstract}
Perceiving the great importance of the moor element in Portuguese culture and emphasizing the significance of introducing this cultural and religious alterity in order to reflect about the cultural immanence, we search, in this thesis, to analyze the diverse figurations of the moors in canonical literary works. We used, for that, fictional texts of historical type, focusing the attention in the literary work of Alexandre Herculano, but also considering the legendary origin of this theme and some of its major significant coincidences in the contemporaneity.
\end{abstract}




\section{SUMÁRIO}

INTRODUÇÃO 11

\section{I - REPRESENTAÇÕES DO MOURO EM PORTUGAL: PERSPECTIVAS} HISTÓRICAS, CULTURAIS, RELIGIOSAS E LITERÁRIAS ..........................14

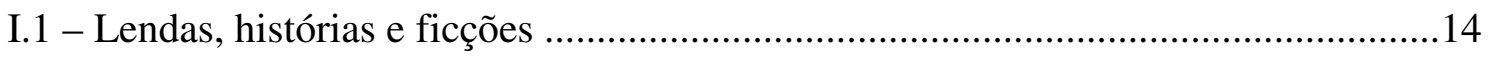

I.2 - Séculos XIX e XX: marcos das representações mouras em Portugal ...................29

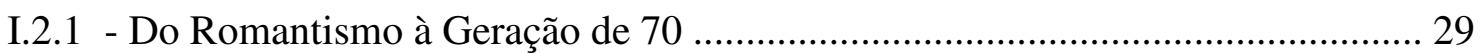

I.2.2 - Aspectos religiosos e civilizacionais: tolerância e conflito .................................34

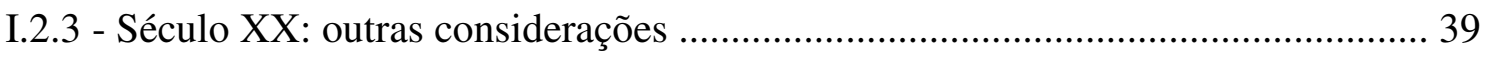

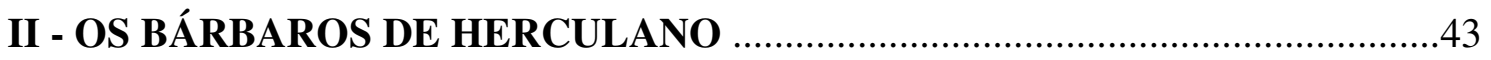

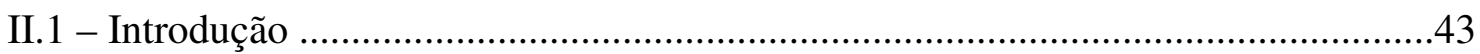

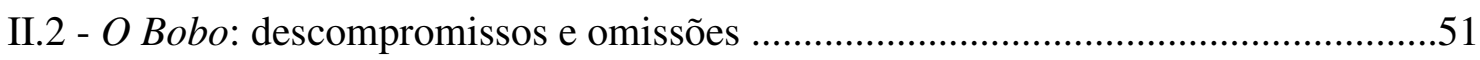

II.3 - Eurico, o presbítero: oposição entre os bárbaros godos e mouros .......................68

II.3.1 - Eurico, o presbítero: a marca de uma geração ...............................................68

II.3.2 - Convergências temáticas: amor, história e guerra em Eurico, o presbítero .......70

II.3.3 - "Destruição de Áuria" e os antecedentes de Eurico ............................................75

II.3.4 - Figurações de mouros e godos em Eurico, o presbítero ....................................80

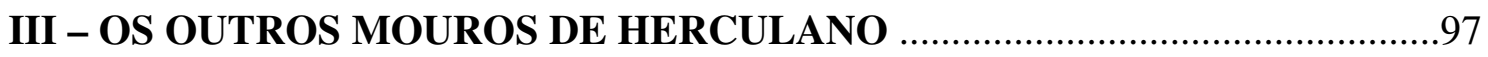

III.1 - O Monge de Cister: um protagonista mouro .......................................................

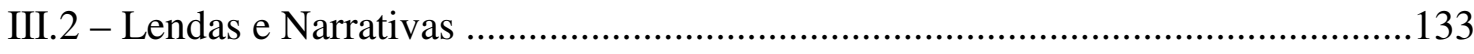


III.2.1 - Introdução 133

III.2.2 - O Bispo Negro 136

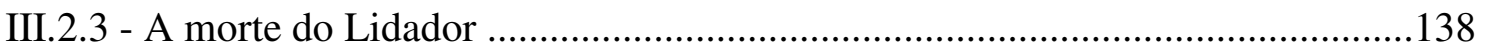

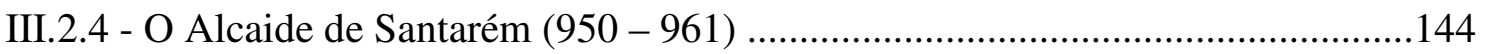

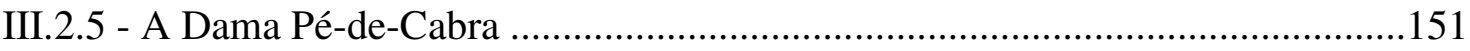

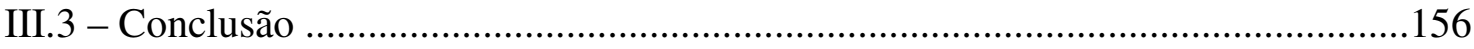

\section{IV - MOUROS E BARBÁRIES NA LITERATURA PORTUGUESA}

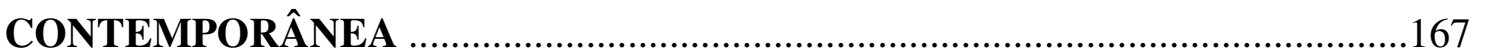

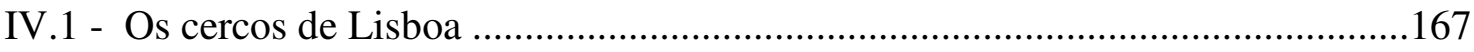

IV.1.1 - Mouros e portugueses: do antagonismo à identificação ................................171

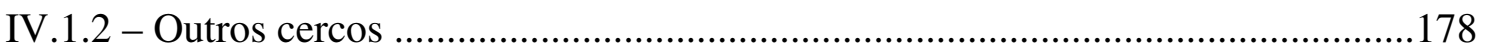

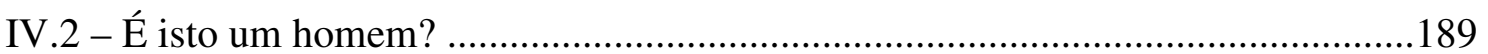

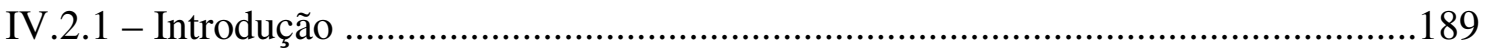

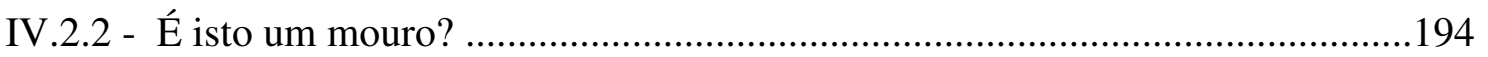

IV.2.3 - A barbárie intrínseca à civilização romana ...................................................202

IV.2.4 - Iunia Cantaber: a ameaça interna .............................................................206

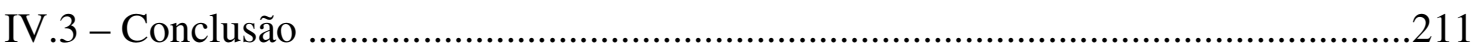

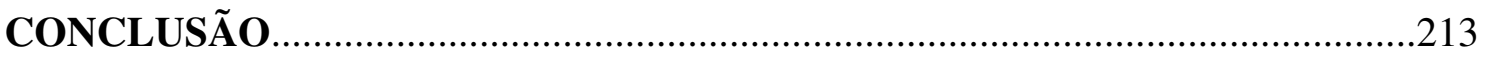

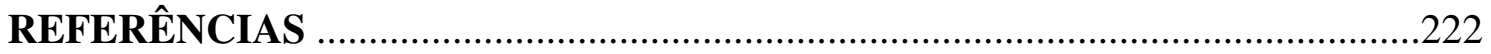

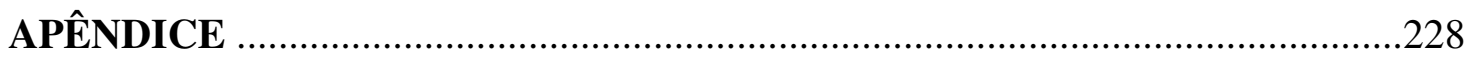

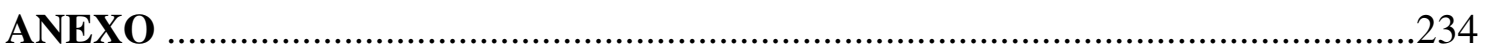




\section{INTRODUÇÃO}

A cultura portuguesa, em suas vertentes folclórica, lendária e literária, contempla, com considerável frequência, a presença moura em Portugal. A forma de abordar o tema, entretanto, apresenta-se, eventualmente, descolada dos fundamentos históricos referentes à ocupação dos mouros. E, mesmo os fatos historiográficos sobre o assunto mostram-se, de modo geral, contraditórios e imprecisos.

A recorrência dessa temática, seguindo contornos ficcionais e folclóricos, parece, assim, compensar uma deficiência factual a respeito dos invasores muçulmanos. E, justamente, devido à autonomia em relação à história e à liberdade imaginativa com a qual se apresenta a figuração do elemento mouro, é que esse conteúdo suscita, também, reflexões sobre a própria cultura portuguesa. Ou seja, utilização simbólica do mouro, designativa de uma alteridade ${ }^{1}$ expressiva e persistente no imaginário português, revela, por conseguinte, as próprias estruturas dessa cultura.

E, deslocando um pouco a discussão, para abordagens mais teóricas sobre o assunto, encontramos em diferentes áreas de atuação, como a filosófica, a sociológica e a histórica, pensadores que apresentam afinidades com essa perspectiva, ressaltando a importância de se introduzir um elemento estrangeiro, "não viciado", representativo de uma alteridade cultural, alheio ao status quo dominante, para se pensar cada umas delas. Em todos eles se coloca a necessidade de se pensar a forma como ocorre a interação

\footnotetext{
1 "Característica do que é do outro. Opõe-se a identidade. [...] Nota: A noção de alteridade é, do ponto de vista lógico, uma relação simétrica e intransitiva [...]. Ela é assim definida como negação pura e simples." (LALANDE, 1999, p.47)
} 
entre duas culturas para que se possa entender melhor cada uma dessas culturas.

Pela impossibilidade de realizar, em uma tese de doutoramento, um levantamento sistemático das obras literárias que tematizam o elemento mouro, buscamos no início do século XIX e final do século XX, períodos de grande ocorrência dos chamados romances históricos, e, também, na época da expansão colonial portuguesa, os textos literários de autores canônicos que abordassem esse tema de forma mais produtiva para o nosso trabalho.

Definimos, como foco principal, obras que abordassem a presença dos mouros na Península Ibérica, e não no ultramar. Para isso abordamos o conjunto da obra ficcional de Alexandre Herculano, relativa ao tema, ou seja, os três romances, quatro dos contos publicados em Lendas e Narrativas, - "O Bispo Negro", "O Alcaide de Santarém”, “A Dama Pé-de-Cabra”, "A morte do Lidador" - além de um quinto texto, compilado posteriormente por Vitorino Nemésio, "Destruição de Áuria". Analisamos, também, dois romances contemporâneos, um de Mário de Carvalho (1994), Um deus passeando pela brisa da tarde, outro de José Saramago, História do cerco de Lisboa (1989).

Assim, iniciando a nossa tese com uma abordagem mais geral referente ao tema, abarcamos, no primeiro capítulo, alguns aspectos históricos, literários e folclóricos que caracterizam a presença moura na Península Ibérica. A seguir, apresentamos análises relativas às obras literárias de Alexandre Herculano. Conforme, explicado, adiante, pareceu-nos mais adequado iniciar tais abordagens com $O$ Bobo. Perfazendo o segundo capítulo, juntamente com tal obra, apresentamos a análise de Eurico, o presbítero. Constituímos, assim, dois parâmetros significativos para se refletir sobre o restante da obra herculaniana. No Capítulo III, apresentamos as análises 
concernentes ao restante da obra literária de Alexandre Herculano, que trata de algum modo da temática moura. Iniciamos o capítulo com $O$ Monge de Cister, por se tratar também de uma narrativa mais longa e, por isso, assemelhar-se mais, do ponto de vista estrutural, a $O$ Bobo e Eurico. A seguir, contemplamos os já referidos textos componentes das Lendas e Narrativas, com exceção de Destruição de Áuria, que, por algumas razões, colocadas no capítulo correspondente, apresenta-se juntamente com Eurico, o presbítero. 


\section{CAPÍTULO I - REPRESENTAÇÕES DO MOURO EM PORTUGAL: PERSPECIVAS HISTÓRICAS, CULTURAIS, RELIGIOSAS E LITERÁRIAS}

\section{I.1 - Lendas, histórias e ficções}

O termo mouro, utilizado em um sentido amplo para definir os invasores muçulmanos da península Ibérica, refere-se, conforme exposto a seguir, a povos de várias origens, mas, sobretudo, aos habitantes islâmicos do norte da África. Conforme anuncia Ana Rita Gaspar Moreira, é possível acompanhar, em diversos autores, “algumas confusões terminológicas" (MOREIRA, 2005, p.78) no que diz respeito à

[...] definição do termo 'mouros', que ora identifica os norte-africanos, sobrepondo-se por vezes com pouca clareza à identificação das populações berberes, ora conserva o âmbito lato que detém no uso comum. (MOREIRA, 2005, p.78)

Em O povo português nos seus costumes, crenças e tradições, Teófilo Braga apresenta uma delimitação mais específica sobre o assunto. Para o autor, os mouros seriam "[...] berberes arabizados, pelo cruzamento, e islamizados, pela conversão" (Braga, 1995, p.281).

Ana Rita Gaspar Moreira relembra, ainda, um excerto da obra, Portugal 
contra os mouros (193-), de David Lopes, no qual o autor admite usar o termo, mouros, de forma pouco precisa, pois, segundo Lopes, essa terminologia foi tomada para designar os habitantes da região da Mauritânia, mas, de fato, o termo referia-se também a outros povos, como os árabes, sírios e persas. E, finalmente, a partir dessas diversas elaborações em torno do termo mouro, a pesquisadora conclui o seguinte:

Mouros são afinal, com alguma consistência, as populações muçulmanas: os dominadores árabes, os berberes islamizados, os muçulmanos que se conservam na península depois da conquista cristã ou os que os navegadores vão reencontrar, a partir do século $\mathrm{XV}$, nas suas expedições em África e na Ásia. (MOREIRA, 2005, p.79)

Mas, há que considerar-se também, conforme ressalta Moreira, que "o termo 'mouros' é ainda frequentemente utilizado como denominador coletivo das populações que se opõem aos reinos cristãos.” (MOREIRA, 2005, p.77). E é, provavelmente, dessa dimensão bélica, que se constituiu, no imaginário Português, uma das principais referências semânticas acerca dos mouros. Conforme ressalta, abaixo, Alexandre Parafita, a formação da nação portuguesa sob o domínio mouro na península terá, certamente, demarcado um sentido de inimizade e antagonismo em relação aos antigos invasores, na memória coletiva do povo:

Obviamente, Portugal, que se formou enquanto nação no seio do domínio muçulmano, não podia furtar-se, no seu inconsciente coletivo, a um imaginário construído sob um caudal denso e organizado de referências à tirania do invasor, cumprindo-se assim o princípio de que a memória coletiva sempre arquiva melhor os atos negativos, devastadores e humilhantes, do que os aspectos positivos, harmoniosos e conciliadores da história. (PARAFITA, 2006, p.23)

Um aspecto inequívoco da influência do contexto bélico, referente ao período de ocupação moura e também da reconquista territorial da península, prevalente ao longo história portuguesa, pode ser identificado na própria bandeira nacional que, 
conforme explica Parafita, “[...] apresenta cinco quinas que representam cinco reis mouros mortos na Batalha de Ourique [...]" (PARAFITA, 2006, p.26). O autor acrescenta, ainda, que os sete castelos componentes da bandeira representariam também “[...] o número de castelos tomados aos mouros por D. Afonso III.” (PARAFITA, 2006, p.26).

Analisando, especificamente, a influência moura na região de Trás-osMontes, em Portugal, Alexandre Parafita apreende duas constatações aparentemente contrastantes: a primeira refere-se às raras menções, no âmbito historiográfico, à presença moura na região; a segunda diz respeito ao abundante número de lendas de mouros mantidas no domínio da tradição oral daquele espaço. Tal desproporção é compreendida, por Parafita, como um mecanismo de compensação do vazio historiográfico pelo preenchimento, de cunho imaginário, através de formas ficcionais e lendárias de expressão oral:

Quanto mais tênues são as referências históricas sobre um determinado fato de contornos marcantes e perversos, mais facilmente o imaginário lhe dá corpo. Assim se explica que no norte interior do País possa haver maior densidade de lendas de mouros do que no sul, onde os muçulmanos tiveram, durante séculos, presença dominante, permanente e generalizada. (PARAFITA, 2006, p.35)

O autor esclarece que, de fato, embora a historiografia não tenha dado conta de tais fatos, há indicadores consistentes da presença e domínio mouros em diversas zonas da região transmontana e que, os muitos flagelos aí ocorridos, como a destruição da Catedral de Santiago de Compostela, teriam encontrado na expressão oral popular uma possibilidade de elaboração para aquelas ações perversas e destrutivas atribuídas aos chamados infiéis. Mas, para além dos fatos específicos relativos à prevalência da dimensão lendária da representação dos mouros na região Norte, há também, no 
contexto nacional português, uma mitificação antagonizada desses povos, condicionada aos mecanismos hitórico-religiosos.

Haveria, assim, principalmente a partir da Reconquista da Península Ibérica, no século VIII, uma demonização dos mouros, que assumiriam uma carga simbólica de absoluto antagonismo nacional e, principalmente, religioso. Parafita chama a atenção para o "quadro de identidade vs. Alteridade" (PARAFITA, 2006, p.44), constituído nesse período: "Daí que, a Reconquista Cristã, iniciada no VIII século, tenha posto o Diabo a encarnar a imagem do "outro", isto é, dos Mouros, e que em muita da sua iconografia estes sejam apresentados com pés de cabra." (PARAFITA, 2006, p.44).

Uma das expressões da atribuição demoníaca aos mouros pode ser verificada em muitas das lendas, oriundas de um contexto medieval, referentes às mouras encantadas. Há uma recorrência de narrativas folclóricas, que conjugam a sensualidade irresistível das mouras e um precioso tesouro por elas guardado, com um fundo maléfico ou demoníaco, do qual fariam parte. Conforme esclarece Alexandre Parafita,

[...] à luz dessa inspiração, construída no contexto de um imaginário medieval, os mouros, com sua riqueza ou com sua sensualidade (corporizada na figura das mouras) produziriam sobre os humanos um efeito tentador, conduzido pelo demônio, cujo objetivo seria atraí-los ao Inferno. (PARAFITA, 2006, p.86)

Parafita ressalta, com base na obra de obra de Adalberto Alves, Portugal: Ecos de um passado Árabe (1999), que mecanismos de atração e repulsa, fascínio e receio, conduzem a relação de alteridade estabelecida entre cristãos e muçulmanos no contexto português. $\mathrm{O}$ autor percebe, da seguinte forma, as intrincadas relações de perigo e fascínio aí implicadas: 
Deste fascínio problemático poderão ter germinado no seio do povo os famosos e inquietantes mitos e lendas de mouros, que, se por um lado, revelam amores sofridos, inviáveis entre cristãos e muçulmanas e vive-versa, por outro, traduzem a perigosidade de um painel de seduções latentes na ilusão de tesouros e de outros encantos que o fenômeno árabe alimenta. (PARAFITA, 2006, p.96)

Gentil Marques ressalta que “[...] foram os Árabes os últimos senhores da Península antes dos cristãos, e os que mais profundas recordações deixaram." (MARQUES, 1999, p.5). Como também afirma Marques, entre tais recordações, a figura da moura encantada seria uma das mais marcantes no imaginário popular, assemelhando-se, por exemplo, às fadas e sereias, pela representatividade e fascínio que elas exercem no contexto lendário ocidental.

Gentil Marques reuniu, no III volume das Lendas de Portugal (MARQUES, 1999) ${ }^{2}$, quarenta e cinco lendas bastante tradicionais, que apresentam os mouros ou mouras como parte significativa de sua temática. Um texto interessante, no que se refere à figura da moura encantada, pode ser aí encontrado, na "Lenda do bolo branco", originária de Silves, no Algarve.

A história narra os fatos ocorridos com Diogo, um trabalhador muito corajoso, ao encontrar a princesa moura encantada, que guardava o tesouro de seu pai, no castelo de Silves. Ele faz um acordo com a moura de levar para ela um bolo bem grande dividido em quatro partes em troca de todo o tesouro do rei. Mas, o pacto previa também que ninguém poderia saber do acordo realizado entre eles, e a mulher de Diogo, intrigada com a atitude estranha do marido, que confeitara tal bolo altas horas da noite, decide parti-lo para ver se havia algo escondido no seu interior. Ao fazer isso ela percebe, horrorizada, que escorria sangue de dentro dele.

\footnotetext{
${ }^{2}$ Apresentamos, no APÊNDICE da tese, algumas sínteses de lendas contidas na obra de Gentil Marques, com intuito de expor temas representativos da tradição de temática moura, aí contidos.
} 
Quando Diogo leva o bolo para a princesa, nota que o cavalo em que ela estava montada tinha uma das patas amputadas e sangrando. Ao cortar o pedaço do bolo sua mulher cortara, na verdade, a perna do animal, no qual a moura pretendia fugir. A princesa moura, então, muito aborrecida com o ocorrido diz que Diogo não cumprira o pacto e que não ganharia o tesouro, mas deu-lhe um cinto para entregar a sua esposa. Diogo descobriu que o cinto era, na verdade, uma lâmina e que se o tivesse dado a sua mulher ela teria sido cortada ao meio. A moura continuou, assim, encantada e presa ao castelo de Silves. (MARQUES, 1999).

Em outras lendas, entretanto, há uma ênfase maior no aspecto sensual e sedutor da moura, exercido, principalmente, sobre os homens cristãos. Na maioria dos casos, a união entre eles é impossível ocorrendo, inclusive, alguma desgraça, como a perdição ou morte do homem seduzido. Mas, em muitas dessas lendas, o principal obstáculo à formação de tal casal encontra-se na figura do pai da moura, representante mais evidente da religiosidade muçulmana, conforme esclarece Parafita:

[...] a figura intransigente e opressora do pai (mouro), como entidade soberana zeladora da idéia anticristã, representa, pela quantidade de incidências, o principal obstáculo a uma relação amorosa entre cristãos e mouros. A sua intervenção vai desde encerrar sua filha 'ao descobrir as suas inclinações amorosas'(em Suçães, Mirandela), até encantá-la em 'bicho horrendo'(no Castelo de Monforte, Chaves) ou numa monstruosa serpente 'com uma grande cabeleira' (no Castelo de Algoso, Vimioso), ou ainda encantá-la e mandar decepar o noivo (na Serra dês. Domingos, Sabrosa). (PARAFITA, 2006, p.87)

Alexandre Parafita diz que, embora a figuração do mouro e da moura ocupe lugares diferentes no imaginário popular, havendo, de maneira geral, “sentimentos de aversão e ódio em relação ao mouro e de complacência e paixão em relação à moura" (PARAFITA, 2006, p.102) ambos apresentariam uma dimensão mítica impregnada de magia e encantamento. O autor rebate, também, as análises que 
estabelecem uma distinção rígida entre as figurações lendárias dos mouros míticos e dos históricos.

De fato, Parafita traça uma linha coerente que relaciona aspectos factuais advindos dos conflitos históricos entre cristãos e muçulmanos com os atributos fantasiosos inerentes ao universo mítico. $\mathrm{O}$ autor chama a atenção, ainda, para o componente ficcional que recairia sobre a própria construção historiográfica, como se pode acompanhar no seguinte excerto:

Quando se reconhece a idéia de 'mouros' como sendo habitantes refugiados em locais inacessíveis, subterrâneos, detentores de poderes exóticos e de imensas riquezas (tesouros), possuidores de mesquitas, mas sobretudo inimigos da fé cristã, não se está, desde logo, a admitir uma clara proximidade, ainda que envolta em uma recreação mítica, com essoutra figura que a história reconhece como os invasores da velha Hispânia, vulgarmente designados também por mouros? E não serão hoje também estes, em face da diluição histórica que sobre eles tem recaído, um produto híbrido da realidade e da mitologia? (PARAFITA, 2006, p.102)

Mas, se ocorre, de fato, uma contaminação entre os aspectos míticos e historiográficos nas representações ficcionais dos mouros, na tradição oral, a expressão escrita da literatura de temática moura, parece, de maneira geral, partir da figuração desse elemento, em sua vertente histórica, para, então, promover uma significação mais simbólica, ou mesmo mítica, associada ao tema. Assim, ao longo do panorama literário português, desde Fernão Mendes Pinto e Luís de Camões, passando pelos romances históricos oitocentistas, chegando até a contemporaneidade, é possível verificar uma gama diversificada de representações de mouros, relacionadas a contextos históricos específicos, mas que alcançam, também, uma dimensão mais abstrata associada a uma alteridade ancestralmente constituída. Relacionado a isso, de alguma forma, percebe-se, ainda, que a figuração do elemento mouro em muitas dessas obras suscita, como 
veremos adiante, reflexões interessantes sobre a própria cultura portuguesa.

Tangenciando tal perspectiva, identifica-se, em alguns casos, a presença moura como uma estrutura mítica autônoma, atuante no contexto cultural e, consequentemente, no discurso literário português, descolada dos fatos históricos oficiais. É o caso, por exemplo, do seguinte excerto da obra de Júlio Dinis: Os Fidalgos da Casa Mourisca (DINIS, 19--), publicada pela primeira vez em (1871). Aqui, o interesse deve-se, justamente, à frustração da expectativa, apresentada pelo título da obra, de uma provável presença de elementos mouros em seu enredo. Mas, a razão do não cumprimento dessa expectativa é já introduzido nos primeiros parágrafos da narrativa, como se pode acompanhar a seguir:

\begin{abstract}
A tradição popular em Portugal, nos assuntos de história pátria, não se remonta do período da dominação árabe nas Espanhas.

Pouco ou nada sabe o povo de celtiberos, de romanos e visigodos. É, porém, entre ele, noção corrente que, em outros tempos, fora este país habitado por mouros, e que só à força de cutiladas e de botes de lança os expulsaram os cristãos para as terras da Mourama. (DINIS, 19--, p.899).
\end{abstract}

Após dissertar sobre vários indícios da memorial presença moura no país, como, "os romances nacionais", que contemplavam as lutas entre os heróicos portugueses e os invasores árabes, os "contos narrados em volta da lareira" sobre as mouras encantadas, os tesouros enterrados por mouros e ainda por encontrar (DINIS, 19--, p.899), o autor, finalmente, explica o aparente descompasso entre o título e o conteúdo do romance: 
Esta mesma noção histórica do povo é que dá lugar a outro frequente fato. Quando, no centro de qualquer aldeia, se eleva um palácio, um solar de família, distinto dos edifícios comuns por uma qualquer particularidade arquitetônica mais saliente, ouvireis no sítio designá-lo por nome de Casa Mourisca, e, se não se guarda aí memória da sua fundação, a crônica lhe assinará infalivelmente, com data, a lendária e misteriosa terra dos mouros. Era o que se sucedia com o solar dos senhores Negrões de Vilar de Corvos, que, em três léguas em redondo, eram conhecidos pelo nome de fidalgos da Casa Mourisca. Não se persuada o leitor de que possuía aquele solar feição pronunciadamente árabe, que justificasse a denominação popular, ou que mãos agarenas houvessem de feito cimentado os alicerces da casa denominada assim. (DINIS, 19--, p.899)

Tal colocação assemelha-se, bastante, ao seguinte comentário elaborado por Leite de Vasconcelos sobre o assunto: "O povo, cuidando que antes dos mouros ninguém existia, serve-se da palavra mouro para designar, não só os monumentos arruinados, mas também os que oferecem uma aparência estranha." (VASCONCELOS, 1999, p.5). É notável, nas duas elaborações, o esvaziamento do caráter factual referente à presença árabe em Portugal e uma arbitrária associação entre os elementos discordantes do padrão cultural comum. É o que se coloca, especificamente, na obra de Júlio Dinis, com associação entre a arquitetura da casa dos senhores Negrões e o universo lendário e exótico criado em torno da ocupação moura nas terras portuguesas.

Pode-se verificar, ainda, pelo menos um caso, em que a utilização simbólica do mouro, designativa da alteridade, contaminou, também, a literatura brasileira. Referimo-nos à obra de José de Alencar, $O$ Guarani. A inserção de uma cantiga referente à relação afetiva entre um mouro e uma cristã, conforme apresentado abaixo, parece-nos, de fato, bastante significativa:

$[\ldots]$

Aos pés daquela a quem ama/Jurou/Ser fiel a sua dama.

A gentil dona e senhora/ Sorriu; / Ai! Que isenta ela não fora!

"Tu és mouro; eu sou cristã." / Falou/ A formosa castelã.

"Mouro, tens o meu amor, / Cristão, / Serás meu nobre senhor."

[...](ALENCAR, 2000, p.289) 
A importância dessa referência deve-se, principalmente, ao contexto retratado nessa obra de Alencar, em que se apresenta a relação entre brancos e índios em um Brasil seiscentista, no qual, surpreendentemente, como em outras obras do autor, o elemento negro é obliterado. Ou seja, a presença do mouro faz-se tão incisiva no imaginário lusófono, como alteridade religiosa e cultural, que, mesmo uma obra canônica, de cunho nacionalista, que elege, apenas, o componente indígena e branco, como fundadores da nacionalidade brasileira, retoma o mouro para metaforizar o índio.

No caso, o índio mencionado na cantiga de Cecília, poderia ser entendido como uma alusão ao personagem Peri, que não se submetera ao cristianismo. Essa analogia simbólica, entre o mouro e o índio, apreendida do texto de Alencar, talvez se tenha viabilizado, justamente, devido ao lugar distanciado e quase mítico assumido pelo elemento indígena na cultura brasileira oitocentista, semelhante ao contexto lendário ocupado pelos mouros no imaginário português.

E, realmente, segundo Boxer, o confronto estabelecido entre portugueses e mouros, no período colonial, parece ter influenciado, posteriormente, as relações dos colonizadores lusitanos com os povos colonizados. Para o autor de As Relações Raciais no Império Colonial Português, o marco inicial da expansão ultramarina, "a captura do forte mouro em Ceuta, 1415" (BOXER, 1967, p.37), foi decisivo na forma como, posteriormente, os portugueses interagiram com os povos submetidos. Daí, talvez, a contiguidade estabelecida entre os mouros, representantes de uma alteridade simbólica para os colonizadores portugueses, com o índio, que assumiria um papel semelhante para os brasileiros.

Os Lusíadas apresentam-se como obra exemplar para se observar esse confronto entre portugueses e mouros no âmbito da expansão. A percepção 
preconceituosa e redutora dos cristãos em relação aos muçulmanos traduz-se aí em expressões pejorativas como, “torpe Ismaelita” (CAMÕES, 19--, p.55), "bárbaro Gentio" (CAMÕES, 19--, p.57), “cães” (CAMÕES, 19--, p.74), "bruta gente” (CAMÕES, 19--, p.76), apenas para citar algumas das formas como são retratados os africanos seguidores de Maomé. Ressaltando, especificamente, esse aspecto contido na obra épica de Camões, António José Saraiva faz o seguinte comentário: “Os Lusíadas exprimem [...] a afetação de um civilizado "ocidental" perante os "bárbaros"." (SARAIVA, 1996, p.98).

Por outro lado, Saraiva destaca a obra de Fernão Mendes Pinto, que, estando também localizada no âmbito da expansão colonial portuguesa, entretanto, relativiza e até mesmo inverte a identificação do povo português com a civilização ${ }^{3}$ e a caracterização bárbara dada aos orientais:

Fernão Mendes Pinto inclina-se até o pólo oposto ao de Camões ao ver nos orientais qualidades de civilização que faziam que em relação a eles os Portugueses fossem os verdadeiros bárbaros. (SARAIVA, 1996, p.98)

Mas, de maneira geral, pode-se dizer que Saraiva identifica em Os Lusíadas uma perspectiva contrária ao padrão corrente, no que se refere à forma como os portugueses se relacionavam com os outros povos, por eles colonizados ou com os quais mantiveram algum tipo de contato. Em uma abordagem semelhante a de Gilberto Freyre (Casa-Grande \& Senzala), o autor de A cultura em Portugal destaca, no comportamento dos portugueses,

\footnotetext{
${ }^{3}$ A noção de civilização será redimensionada ao longo da tese, mas, apresentamos, a seguir, duas definições dicionarizadas do termo, que nos servem como base. "A. Uma civilização é um conjunto complexo de fenômenos sociais, de natureza transmissível, apresentando um caráter religioso, moral, estético, técnico ou científico, e comuns a todas as partes de uma vasta sociedade, ou a várias sociedades em relação. [...] B. A civilização (oposta ao estado selvagem ou à barbárie) é o conjunto das características comuns às civilizações (no sentido A) julgadas mais elevadas, quer dizer, praticamente a da Europa e dos países que a adotaram nos seus traços essenciais." (LALANDE, 1999, p.163)
} 
[...] uma certa liberdade em relação às fronteiras culturais, uma certa promiscuidade entre o Eu e o Outro, uma certa falta de preconceitos culturais, a ausência do sentimento de superioridade que caracteriza, de modo geral, os povos de cultura ocidental. (SARAIVA, 1996, p.98)

Para António José Saraiva, esta seria, ainda, a explicação para o fato de os negros, assim como os judeus e mouros que ficaram em Portugal, terem "desaparecido", para ele, isso "só se explica por terem sido assimilados pela maioria branca" ao invés de se isolarem em ghettos (SARAIVA, 1996, p.98).

Mas, conforme vimos anteriormente, o contexto relativo às relações amorosas entre portugueses e mouros, parece ter constituído elaborações lendárias bastante conflituosas no imaginário lusitano. Em uma perspectiva generalizante, podese dizer que a sedução da mulher moura pelo português é concebida como um evento positivo, um tipo de submissão e conquista, que talvez tenha como fundo uma analogia com a própria conquista territorial.

Por outro lado, a relação amorosa da mulher portuguesa com o mouro é caracterizada, de modo geral, como uma ação imoral, vinculada a um contexto de traição, que culmina, em muitos casos, com uma punição fatal para ambos. Abaixo, um caso bastante paradigmático dessas conturbadas relações amorosas entre muçulmanos e cristãos com os componentes de traição, vingança, poder e submissão aí implicados:

Foi certamente Ramiro que deixou um rasto lendário, recolhido nos livros de linhagens portugueses. Ele, segundo a lenda, matou o rei mouro Gaia, que lhe tinha roubado a mulher; matou também a mulher, que o havia atraiçoado com o mouro, e casou com uma moura chamada Artiga, que no batismo mudou o nome para Aldara. Deste casamento nasceu Albozar, grande conquistador de terra aos Mouros, à volta do Porto e entre o Douro e o Mondego. (SARAIVA, 1996, p.22)

Essa temática foi também desenvolvida por Almeida Garrett, no início de 
suas atividades literárias, com o poema Dona Branca. A obra retrata o rapto de D.Branca pelo chefe mouro Aben-Afan e uma posterior relação afetiva entre eles. Também aqui, ocorre a punição do mouro, Aben-Afan, que ousara se relacionar com uma mulher cristã, sendo morto em um combate com os cristãos. Apresenta-se, ainda, o sofrimento trágico de D. Branca que acaba enlouquecendo após a morte do amante.

O poema recorre, também, a muitos fatos do repertório fabular acerca dos mouros, como o caso de Oriana, uma moura encantada, abarcando, ainda, episódios de magia e ressurreição de mortos, entre outros. Mas, para além, dessa disposição previsível cumprida ao longo do poema, observa-se também uma reflexão sobre o caráter bárbaro dos próprios europeus, como se pode acompanhar, abaixo:

Culpas, Europa, o muçulmano bárbaro?

E os teus cárceres negros e traidores,

Onde à inocência cândida, à piedade

Arma pérfido bonzo o laço astuto, Laço, que, eterno, a vida, os gozos dela, A ventura, o prazer de um nó separa?

Corta sem dó - cruéis! - e até cerceia

O derradeiro bem de um desgraçado,

[...]

[...] - Homem bárbaro,

Ingrato e desleal, qual é o seu crime? (GARRETT, 1963, p.483)

Nessa espécie de digressão, podemos apreender a denúncia de uma prática européia bastante hipócrita, que localiza apenas no muçulmano as características de um comportamento bárbaro. Após descrever atitudes violentas e cruéis praticadas também pelos europeus com as mulheres escravizadas, coloca-se, finalmente, a designação do europeu como o verdadeiro "Homem bárbaro."

Em outra obra de Almeida Garrett, $O$ Arco de Sant'Ana, referente à época de D. Pedro I (século XIV), é na representação dos elementos judaicos que se percebe alguma relevância, mas ocorre aí também, em um ponto específico da narrativa, uma 
referência à participação moura na formação da nacionalidade portuguesa, colocando-a, inclusive, de forma desierarquizada, ao lado do componente judaico e godo. Assim, pode-se acompanhar, na seguinte descrição referente às três personagens, Aninhas, Ester e Gertrudes, uma metáfora às componentes étnicas que teriam constituído Portugal:

Eram três e todas três belas, essas figuras; porém tão diversas uma da outra, que se caracterizavam nelas os três tipos distintos das raças portuguesas que então eram [...] Romano-celta a mais baixa, a mais viva. [...] Mais suave e mais doce a outra, mais alta e menos direita, mais débil e mais feminina toda, denuncia o puro sangue da raça germânica que ou se não misturara com outros, ou por singular capricho da natureza se extremou ao formar desse ente no seio materno. [...] Mas puro, puríssimo sangue da Arábia é a terceira que, através de um véu que lhe cobre o rosto, respira o queimor ardente do deserto, e nas sós formas de seu corpo, no seu jeito, no seu ar, revela todo o oriente e faz perguntar: Será esta Deborah, será Judite, será a mãe dos Macabeus? (GARRETT, s.d., p.173)

Mas, no século XIX, e possivelmente na Literatura Portuguesa, em geral, é Alexandre Herculano o grande depositário da cultura medieval e, com ela, da temática moura. Ao longo de quase toda a sua ficção histórica são notórias as referências à presença moura na Península Ibérica. Tanto em Eurico, o presbítero, como em O Bobo, O Monge de Cister e em vários contos componentes das Lendas e Narrativas os mouros são representados de forma coletiva, nos exércitos muçulmanos, ou individualmente, como personagens secundários (à exceção de "O Alcaide de Santarém"), cuja representação suscita reflexões importantes para se pensar o seu lugar no interior da cultura portuguesa. Na verdade, a própria cultura e o passado histórico portugueses são amplamente referenciados na literatura de Herculano e a figuração do mouro, nesse contexto, parece instigar possibilidades ainda mais abrangentes para se pensar a imanência nacional. 
No seguinte tópico, a partir de considerações de diversos autores, entre os quais, o próprio Alexandre Herculano, abordaremos algumas perspectivas que contemplam, no campo histórico, social e religioso, a presença moura no contexto português. 


\section{I.2 - Séculos XIX e XX: marcos das representações mouras em Portugal}

\section{I.2.1 - Do Romantismo à Geração de 70}

Ana Rita de Pádua Gaspar Moreira (MOREIRA, 2005) destaca a significância da delimitação de pesquisas referentes à presença árabe em Portugal, a partir do século XIX, pois aí, exatamente, teria se constituído um novo sentido para nação, vinculado à noção de povo. Também Alexandre Herculano é, nesse contexto, identificado como uma das figuras determinantes dessa nova concepção nacional em Portugal:

Antes do século XIX, a nação é pensada, segundo José Mattoso, como uma entidade fundada por vontade divina. O século XIX português racionalista, romântico e liberal, desloca o fundamento nacional para o conceito de volksgeist, ou "espírito do povo". A noção de "espírito do povo", introduzida pelos exilados liberais, de entre os quais se destaca Herculano, tenta, na perspectiva de Mattoso, alicerçar a nação num plano natural [...] (MOREIRA, 2005, p.26)

Em Árabes e Nação na periferia da Europa (MOREIRA, 2005), ressaltamse duas temáticas, aparentemente divergentes, que se destacaram no período romântico da história portuguesa: "o desenvolvimento de uma historiografia nacional e 
nacionalista" e "a moda orientalista européia" que, na Península Ibérica, "insistirá na tonalidade arabizada e africanizada daquelas paisagens e da sua história [...]" (MOREIRA, 2005, p.5). De fato, o retorno ao passado medieval, recorrente na primeira metade do XIX, traz em seu cerne, tanto a demanda nacionalista, referente à gênese da nação portuguesa, quanto a ênfase no elemento mouro, presente no interior dessa cultura. Gaspar Moreira destaca ainda, evocando Castelo Branco Chaves, que, no decorrer do século XIX, uma perspectiva de exotização da Península Ibérica, como lugar da superstição, fanatismo religioso e barbárie, encontrou subsídios nas analogias com o Oriente, e, especificamente, na presença moura no passado Ibérico.

Alexandre Herculano é referido na tese de Ana Rita Moreira pelo seu pioneirismo "no tratamento crítico das fontes medievais" (MOREIRA, 2005, p.15), pois, além dos documentos oriundos de fontes cristãs, o autor lançaria mão, também, de fontes árabes, podendo confrontar a diversidade das perspectivas aí apresentadas. A autora identifica, de fato, em Herculano, “[...] a principal referência historiográfica no que respeita ao período medieval e, em concreto, à interpretação do contato entre cristãos e muçulmanos [...]" (MOREIRA, 2005, p.15). Na História de Portugal, de Alexandre Herculano, Moreira percebe a primeira consideração importante ao AlAndaluz, apontando, particularmente, a abordagem da “[...] população moçárabe e a convivência entre mouros e cristãos, antes e depois da Reconquista." (MOREIRA, 2005, p.15).

António Dias Farinha afirma também que, "O período que antecedeu a formação de Portugal no século XII foi conhecido muito imperfeitamente antes dos trabalhos de Herculano." (FARINHA, 1977, p.323). O autor diz, ainda, que embora a História de Portugal seja a principal contribuição de Herculano para o conhecimento 
sobre a presença muçulmana no país, sua obra literária, de forma semelhante, acrescenta elementos significativos sobre o assunto, permitindo, inclusive, que se acompanhe a partir de seus textos literários “a evolução do seu pensamento sobre a civilização árabe." (FARINHA, 1977, p.323)

Farinha chama a atenção, entretanto, para a "dicotomia do estilo herculaniano ao evocar a época muçulmana nas suas várias obras" (FARINHA, 1977, p.326). Segundo o autor, há uma variação entre a apresentação fiel de dados históricos documentados e a busca de nexos coerentes para descrever esses dados, ocorrendo um julgamento pessoal sobre os fatos. E, como resultado disso, Antonio Dias Farinha aponta as "[...] séries de frescos animados umas vezes pela intuição genial sobre a vida dos povos e a ação dos homens mas, outras vezes, por sínteses demasiado breves íamos escrever contraditórias - da exploração histórica a que procedera." (FARINHA, 1977, p.326). E, sobre a apreciação final de Herculano, na parte de sua historiografia concernente aos muçulmanos, Farinha faz ainda a seguinte colocação:

[Herculano] Historiou demoradamente e com o rigor possível a época árabe-muçulmana, acompanhando-a de julgamentos favoráveis, e, quando esperávamos a conclusão lógica desse exame, assistimos a um quase subtraimento do passado sarraceno. Esta falta tem sido ressentida por historiadores atuais que procuram valorar o passado muçulmano na história da civilização portuguesa. (FARINHA, 1977, p.332)

Ana Rita Gaspar Moreira ressalta, no entanto, que foi a partir de Herculano que se passou a modalizar a relação entre portugueses e mouros, atribuindo-se, inclusive, uma superioridade intelectual a estes povos, considerando, também, a partir daí, a convivência pacífica entre eles e a benignidade e respeito dos invasores pelos invadidos: 
[...] parece existir, a partir de Herculano, um esforço de consolidação da idéia de que durante os séculos de presença árabe na Península ocorre algo mais que o combate ininterrupto entre cristãos e mouros. A atenção sobre as populações de moçárabes e berberes permite a elaboração de enunciados alternativos focando um tempo longo de coexistência. A idéia de uma convivência pacífica pode comportar graus ou frequiências diversas, tomar todo o território ou apenas uma parte, mas é, desde Herculano, incontornável. A superioridade, relativa ou absoluta, genuína ou espúria, da civilização invasora, e a enigmática tolerância com que tratam as populações subjugadas são dois outros motivos que se tornam persistentes. (MOREIRA, 2005, p.99)

Mas, além desse ponto diferenciador em relação ao entendimento da presença árabe em Portugal, definida a partir de Herculano, no qual se estabelece uma positivação da relação entre invasores e invadidos, Gaspar Moreira ressalta, entretanto, duas questões ainda persistentes no que se refere ao longínquo confronto entre os dois povos:

A idéia de um fosso cultural entre os invasores e os resistentes das Astúrias, entre a sofisticação árabe e a rusticidade dos godos, parece ficar marcada com nitidez na imaginação dos autores. Não obstante, subsiste, paralelamente, a noção de que existem rivalidades insanáveis a várias ordens - religiosas, civilizacionais, raciais - que impedem a anulação da diferença. (MOREIRA, 2005, p.100)

Ressalta-se, no mesmo âmbito, o princípio do século XIX, a ênfase na delimitação entre norte e sul de Portugal, constituindo-se aí as imagens poéticas do Algarve arábico. Esse fato teria ocorrido paralelamente ao desenvolvimento dos estudos referentes à presença muçulmana na região, conduzidos, principalmente, por Alexandre Herculano e, anos depois, por David Lopes (MOREIRA, 2005, p.33). José Garcia Domingues, no artigo, "Presença árabe no Algarve", percebe também, no contexto especificamente literário português, referente ao Romantismo, o fenômeno da modificação da "arabofobia para uma arabofilia" (DOMINGUES, 1986, p.113). 
Tal modificação é notada ainda, entre diversos outros pesquisadores, por Abdoolkarim Vakil, na obra From the Reconquista to Portugal Islâmico. O autor destaca os seguintes pontos de convergência, que propiciaram a retomada do período medieval e do contexto mourisco, como temáticas recorrentes no romantismo, “[...] a investigação e coleção de romanceiros populares, a emergência do romance histórico como moda literária e o culto romântico do exótico." (VAKIL apud MOREIRA, 2005, p.34).

Mas, esse quadro sofrerá alguns deslocamentos com a passagem da estética e dos ideais próprios do Romantismo para outras disposições culturais, literárias e intelectuais constituídas pela Geração de 70. A dessacralização e desmistificação da origem portuguesa, apresentadas, em 1846, na História de Portugal de Alexandre Herculano, por exemplo, serviriam de mote para que a geração de 70 buscasse as origens étnicas para a nação. Ana Rita Gaspar Moreira faz o seguinte comentário sobre o assunto:

\footnotetext{
A década de 1870 marcará, de acordo com esta perspectiva, o início da procura de antecedentes étnicos para a nação, uma tarefa que se constitui entre os intelectuais portugueses como resposta à insuficiência da tese voluntarista de Herculano. (MOREIRA, 2005, p.29)
}

Gaspar Moreira acrescenta também, aludindo a perspectiva de Abdoolkarim Vakil, que "será apenas com a Geração de 70, com a racialização do debate sobre as origens, que os Mouros e o Islão começam a interessar os intelectuais portugueses" (MOREIRA, 2005, p.34). Assim, o interesse do final do século XIX pelo tema parece, de fato, mais vinculado a uma abordagem científica sobre o assunto, perpassada, certamente, pelos contributos da Antropologia e Arqueologia. Mas, das conclusões de Vakil sobre as obras publicadas nesse período, Ana Rita Gaspar Moreira ressalta, 
entretanto, que, ainda nesse contexto, haveria um vínculo afetivo importante "com o passado islâmico, que os autores relacionam com memórias familiares, no impulso inicial do interesse científico pelo tema”. (MOREIRA, 2005, p.35)

\section{I.2.2 - Aspectos religiosos e civilizacionais: tolerância e conflito}

Ainda dentro do contexto oitocentista, uma questão bastante polêmica

refere-se às diversas formas como os historiadores compreendem e relacionam os fatores religiosos e civilizacionais relativos à presença árabe na península Ibérica. Ana Rita Moreira destaca, entre as múltiplas perspectivas sobre o assunto, apenas uma constante que perpassaria o conjunto das obras por ela analisadas: “[...] $\mathrm{o}$ reconhecimento da inimizade religiosa como conflito essencial" (MOREIRA, 2005, p.119).

Gaspar Moreira verifica, em vários autores oitocentistas, uma depreciação do islamismo, na qual essa religião seria apresentada "como testemunho de inferioridade e decadência civilizacional" (MOREIRA, 2005, p.85). Por outro lado, muitos desses autores identificam no cristianismo um signo de civilização. Entretanto, cristianismo e islamismo teriam uma origem semita comum, o que tornaria problemática a atribuição da absoluta negatividade depositada no islamismo. Para resolver a questão, Oliveira Martins (MARTINS, 1955), por exemplo, dividiria os semitas entre as tribos do norte, associadas aos parâmetros civilizacionais, de onde viriam os cristãos, e as do sul, sempre vinculada à barbárie, de onde se originariam os povos islâmicos. 
Mas, interessa-nos aqui, particularmente, a perspectiva de Alexandre Herculano, divergente de Oliveira Martins, no que diz respeito à responsabilidade étnica dos fatores civilizacionais. Herculano aponta na religião e nas questões morais por ela suscitadas os fatores determinantes da civilização. Assim, o cristianismo não funcionaria como reflexo de determinado grupo étnico, mas, contrariamente, seria a própria especificidade moral da religião que definiria e determinaria o caráter civilizacional dos grupos, como sugere o seguinte excerto:

Já Alexandre Herculano encontrava no islamismo a principal razão da regressão das civilizações orientais, descobrindo aí o valor distinto dos dois monoteísmos para o progresso geral da humanidade. Ao contrário de Oliveira Martins, é no próprio sistema moral, e não na capacidade intrínseca dos povos que o elaboram, que Herculano vai encontrar a imperfeição. Enquanto que o cristianismo se impõe como força pacificadora, constituindo-se desse modo como um instrumento de progresso sobre os povos bárbaros, o islamismo, instigando o fanatismo e a violência, sempre se mostrará "inábil para constituir sociedades regulares e duradouras"; se o primeiro consegue transformar tribos bárbaras em civilizações, o segundo sabe apenas reconduzir estados civilizados à barbárie. (MOREIRA, 2005, p.86-87)

De fato, no que se refere às diferentes considerações dos autores oitocentistas, em geral, a respeito da influência dos componentes étnicos e religiosos sobre os aspectos civilizacionais dos povos, são apontadas, por Ana Rita Moreira, duas distinções fundamentais: "[...] a distinção religiosa, mais antiga e persistente, e a distinção "etnogênica", infundida pelas novas cosmologias raciais." (MOREIRA, 2005, p.87).

A pesquisadora observa, na historiografia de Francisco de Almeida e Araújo (1852), o destaque para uma crescente reavaliação dos invasores muçulmanos pela população peninsular. Gaspar Moreira esclarece que, para o historiador, passada a rivalidade própria da situação de conquista, os peninsulares puderam reconhecer e 
admirar a civilização árabe (MOREIRA, 2005, p.89).

Mas, Ana Rita Moreira defende que, apesar das perspectivas que relativizam a oposição irreconciliável entre os árabes e os habitantes da península, prevaleceu sempre a idéia de inimizade entre essas populações. A pesquisadora toma como exemplo as considerações propostas por Júlio Vilhena (1873, p.129) sobre o assunto: “[...] o ódio contra os mouros atravessa [...] todo o período de contato entre godos e árabes, determinando a inicial ausência de comunicação e as posteriores perseguições religiosas" (VILHENA apud MOREIRA, 2005, p.90). E corroborando, também, essa perspectiva, Gaspar Moreira retoma Alexandre Herculano, que apontaria, conforme foi visto, o islamismo como fator de desordem e obstáculo para a continuidade do processo civilizatório. O seguinte excerto da historiografia de Herculano, nos dá, de fato, a idéia da negatividade contundente como o historiador percebia a religião muçulmana:

O quadro que nos oferece a Espanha repete-se em África, na Ásia, onde quer que os sectários do Profeta levaram a fé muçulmana e a organização que em tal crença se fundava. Era ela, pois, a causa do mal. (HERCULANO apud MOREIRA, 2005, p.90).

Mas, se a questão religiosa é, frequentemente, associada ao caráter civilizacional de uma nação, como se coloca, por exemplo, na Conferência amplamente conhecida, apresentada por Antero de Quental, Causas da decadência dos povos peninsulares, Consiglieri Pedroso (1883, p.58) parece levar ainda mais longe tal proposta. Ana Rita Moreira assinala que, para o autor, a religião seria, não apenas, um "um elemento determinante no movimento da história", mas, também, modificadora “dos fenômenos sociológicos” (MOREIRA, 2005, p.87).

A pesquisadora ressalta, ainda, logo abaixo, um trecho da obra de Pedroso, no qual o autor estabelece uma comparação, um tanto viciosa e caricata, sobre a relação 
entre islamismo, catolicismo e protestantismo com o processo civilizacional:

[...] quem se negará a ver no islamismo a causa dos rápidos progressos, mas também da rápida decadência dos árabes? No protestantismo a causa, ou pelo menos uma das causas da crescente civilização das raças germânicas? No catolicismo ortodoxo e cheio de fanatismo um dos motivos concorrentes, senão o principal, da decadência dos reinos da península? (PEDROSO apud MOREIRA, 2005, p.87)

Curiosamente, Ana Rita Gaspar Moreira encontra, tanto na historiografia de Herculano como na História de Portugal Popular e Ilustrada de Pinheiro Chagas, constatações de uma atitude tolerante dos mouros invasores para com os cristãos. De fato, segundo Alexandre Herculano, os mouros teriam respeitado a crença e também as propriedades e instituições civis dos portugueses. Mais do que isso, Gaspar Moreira salienta que o historiador atribui a benignidade dessa relação, justamente, aos códigos vigentes do islamismo (MOREIRA, 2005, p.91). Por outro lado, a pesquisadora destaca, como fato significativo, que autores nortenhos, nomeadamente Alberto Sampaio e Basílio Teles, restrinjam a tolerância árabe apenas ao sul do país, destacando no norte a crueldade e violência de suas ações.

A autora apresenta, ainda, outra forma de elaboração dos fatos referentes à relação tolerante dos árabes para com os portugueses, durante a ocupação da península, identificada em Oliveira Martins e Correia Barata. Esses autores perceberiam um interesse político e econômico, na atitude amistosa dos muçulmanos, que teria como finalidade consolidar o domínio árabe em Portugal, subjugando mais facilmente a população. Oliveira Martins vai ainda mais longe, observando uma atitude desdenhosa dos invasores, conforme afirma Ana Rita Gaspar Moreira: 
A tolerância árabe é, na perspectiva de Oliveira Martins, para além de interesseira, orgulhosa. Na História da Civilização Ibérica, o autor distingue na amena ocupação muçulmana a condescendência dos vencedores face as populações que consideram intelectualmente inferiores. (MOREIRA, 2005, p.92)

Entretanto, é possível acompanhar, também, entre os autores oitocentistas, algumas apreciações que focalizam, especificamente, o desenvolvimento cultural e material dos povos árabes, no período em que ocuparam a península. Gaspar Moreira encontra nas obras de Teófilo Braga, Pinheiro Chagas, Oliveira Martins e Alexandre Herculano, entre outros, apreciações positivas sobre a civilização árabe que, em alguns momentos, parecem mesmo conflitantes com a perspectiva que apresentam sobre a influência da religião muçulmana no processo civilizatório. Em diversos textos, inclusive, os godos, ou as nações cristãs, de maneira geral, são vistos como civilizacionalmente inferiores aos árabes.

As palavras de Oliveira Martins (1972, p.138), destacadas no texto de Ana Rita Gaspar Moreira, exemplificam bem essa perspectiva. O autor declara que o estado de desenvolvimento cultural árabe seria "de um modo absoluto e independentemente de quaisquer considerações, [...] superior ao das nações cristãs" (MARTINS apud MOREIRA, 2005, p.93). Gaspar Moreira complementa tal proposição afirmando que, de fato, "a superioridade material da civilização árabe é um argumento resistente no discurso sobre a Península Ibérica na Idade Média.” (MOREIRA, 2005, p.93). A pesquisadora destaca, ainda, um excerto da obra de David Lopes (193-, p.6), no qual o autor apresenta o século $\mathrm{X}$ como ponto alto da dominação árabe e assevera que nesse período nenhuma outra civilização lhes era superior em termos e culturais (MOREIRA, 2005, p.93).

Mas é, justamente, em Alexandre Herculano que Ana Rita Gaspar Moreira 
encontra uma relativização desse ponto de vista. Pois, embora o historiador ressalte a superioridade cultural, administrativa e industrial dos árabes, ele adverte que os leoneses "têm uma moral fundada numa religião mais perfeita e melhores instituições políticas, em particular um ideal de liberdade de raiz germânica que contrasta com o despotismo semita" (HERCULANO apud MOREIRA, 2005, p.94)

Já António Dias Farinha também ressalta, com outros argumentos, o modo favorável como Herculano percebe e descreve a expansão árabe no Andaluz: "Salientou a boa administração civil, o sistema de cobrança de impostos e, sobretudo, a tolerância religiosa como explicação desse feliz resultado" (FARINHA, 1977, p.328). E, sobre a problemática consideração religiosa do historiador sobre os muçulmanos, Dias Farinha, como outros críticos, afirma que tal postura advém do fato de Alexandre Herculano não possuir conhecimento muito consistente acerca do islamismo (FARINHA, 1977, p.327).

\section{I.2.3 - Século XX: outras considerações}

Abdoolkarim Vakil demarca, ao longo do século XX, dois momentos da história portuguesa nos quais a temática islâmica se fez presente de forma mais incisiva: o Estado Novo e o pós-25 de abril. No primeiro momento o autor destaca:

[...] a relação inextrincável entre o tema da "Reconquista" e a idéia colonialista sobre a missão civilizadora/cristianizadora de Portugal. O volte face ocorre nos anos 60 com a capitalização do legado islâmico na propaganda luso-tropicalista de um Portugal multi-religioso e multicultural. (VAKIL apud MOREIRA, 2005, p.35)

Já em relação ao contexto português, pós 1974, destacado por Vakil, Ana

Rita Gaspar Moreira assinala que ocorreria aí um "momento de resgate daquele 
passado" que teria sido integrado, de forma intransigente, pela ditadura, ao próprio passado nacional. (MOREIRA, 2005, p.35). De fato, se durante o Estado Novo, a apropriação do legado árabe era revertida em discurso nacionalista e, consequentemente, em propaganda colonialista, o contexto pós-revolução apresentaria uma abordagem menos utilitária e imediatista sobre a herança árabe em Portugal.

Maria Cardeira da Silva destaca, nesse mesmo período, "uma multiplicação das investidas nos estudos e no interesse pela herança árabe, mais visível no âmbito da arqueologia" (SILVA, 2005, p.796). A pesquisadora acrescenta, ainda, que o motivo multiculturalista oitocentista seria aí retomado, mas em uma vertente ideológica diversa, acrescentando, por exemplo, "a ligação mediterrânica". Mas, Cardeira da Silva esclarece que tal interesse seria originado, na verdade, na década de 50, "quando um plano de ocupação científica dos territórios coloniais incentiva os estudos fora do contexto da metrópole, apontando agora não sobre os árabes, mas sobre o Islão" (SILVA, 2005, p.788).

Ana Rita Gaspar Moreira, em uma análise comparativa entre o orientalismo português e aquele apresentado por Edward Said, referente ao contexto francês e inglês, percebe algumas especificidades que tornam as representações dos árabes em Portugal um pouco deslocadas da forma como aqueles países entendem e representam o oriente. Uma das principais conclusões de Gaspar Moreira, sobre o arabismo português no século $\mathrm{XX}$, refere-se ao seu retorno ao âmbito nacional sob a forma de um discurso identitário:

[...] o suporte da sua esforçada sobrevivência através do século XX é fundamentalmente a elaboração de um discurso identitário sobre a nação que se desdobra na história medieval e na história da expansão. (MOREIRA, 2005, p.37). 
Gaspar Moreira referindo-se a essa atitude como "interesse autocêntrico do arabismo português" encontra aí uma divergência com a proposta européia mais canônica, que exotiza o elemento mouro. Maria Cardeira da Silva aponta, também, o "projeto identitário nacional, expresso na procura da etnogênese da nação" como principal razão para que, desde Herculano, se traga à baila, de forma apenas figurativa, o elemento árabe (SILVA, 2005, p.784).

Ana Rita Moreira ressalta, em uma linha de raciocínio semelhante, que o arabismo português ou a imagem orientalizada de Portugal é, de maneira geral, circunscrita a um espaço específico correspondente à região do Alentejo e Algarve, "sacrificando uma parte do seu território à imagem arcaizada do Oriente" (MOREIRA, 2005, p.37).

E, por fim, a pesquisadora afirma que a herança árabe, em Portugal, é positivada na medida em que “[...] é tomada como razão da predisposição "solar", "aberta e comunicativa" da cultura portuguesa", um capital diplomático na afirmação de Portugal como mediador privilegiado entre o Norte e o Sul [...]" (MOREIRA, 2005, p.37).

Percebe-se, assim, que, ao longo do século XX, ocorreram algumas variações nas formas como o legado árabe foi abordado nos âmbitos científicos, acadêmicos e até mesmo políticos, em Portugal. Se o Estado Novo se apropriou dessa herança como lastro para manutenção dos interesses colonialistas, foi também a partir desse período, particularmente da década de 50 em diante, que o Islão, ou a presença dos árabes no ultramar, tornou-se foco de interesse. Depois da Revolução de 25 de abril o interesse propagandístico e utilitário pelo tema se desfaz, mas prossegue-se aí, de forma diversa e atualizada, o interesse multiculturalista herdado do século XIX. 
Entretanto, como foi visto, ainda, perpassa todo esse trajeto uma outra perspectiva notada, também, desde o Romantismo, que compreende o legado árabe de forma autocentrada, como parte um projeto identitário nacional.

Encerramos esse tópico com uma reflexão de Alexandre Parafita sobre a relação de alteridade e identidade estabelecida entre mouros e portugueses. $\mathrm{O}$ autor elabora uma argumentação que, embora generalizante, nos parece bastante apropriada àquela percepção apontada acima referente à especificidade de um arabismo autocêntrico no contexto português:

[...] através do Outro se de fine o Eu. O Outro dá nos forma, dá-nos dimensão. Os critérios definidores daquele que identificamos como o Outro vêm afirmar e robustecer os critérios com os quais nos definimos e projetamos, num quadro dualista que opõe as noções de identidade e alteridade. Por isso, o Outro é, inevitavelmente, um filho bastardo do nosso etnocentrismo. (PARAFITA, 2006, p.129) 


\title{
CAPÍTULO II - OS BÁRBAROS DE HERCULANO
}

\section{II.1 - Introdução}

\begin{abstract}
Alexandre Herculano, considerado, juntamente com Almeida Garrett, iniciador e expoente do Romantismo em Portugal, tem, não apenas, sua obra amplamente referenciada nos estudos literários relativos ao século XIX, como também sua atuação pública e suas concepções ideológicas e políticas, analisadas como fatores determinantes para a configuração cultural e histórica dessa época. Pode-se acompanhar, por exemplo, na seguinte colocação de Eduardo Lourenço, o destaque dado à influência de Herculano no Romantismo português:
\end{abstract}

[...] graças aos criadores do nosso Romantismo, Almeida Garrett e Alexandre Herculano, essa época sem precedentes na nossa história e por via de conseqüência, na nossa cultura foi pensada $\mathrm{e}$ admiravelmente pensada, de acordo com as necessidades e urgências profundas do país, como nunca mais o será. À sua maneira, poeticamente um, ideológica e filosoficamente outro, Almeida Garrett e Alexandre Herculano refundaram Portugal, reenquadrando, repensando e remitificando o nosso imaginário cultural. (LOURENÇO, 1999, p.104)

Como se vê, Lourenço encontra em Herculano e Garrett os avatares de uma reformulação cultural portuguesa, iniciada no Romantismo. Nota-se, ainda, que o grande destaque dado a Herculano refere-se mais a sua contribuição ideológica e 
filosófica do que, propriamente, à literária. Muitos outros críticos, de forma ainda mais incisiva que Lourenço, adotam, também, a expressiva figura pública de Alexandre Herculano - apreendida tanto em suas ações, como, principalmente, em seus textos de cunho político-ideológico, publicados em jornais e revistas -, como principal parâmetro para a compreensão e análise da participação do autor no Romantismo português.

Ocorre, então, que apesar de toda a visibilidade de que goza Alexandre Herculano, a crítica literária em torno de seu trabalho parece um tanto contaminada, ou mesmo limitada, por aspectos extrínsecos a sua obra, tendo como consequência a omissão de elementos literários, incompatíveis com determinadas expectativas ideológicas que se tem do autor. Assim, a caracterização sisuda, moralista e modelar que perpassa a apreciação de Herculano, como homem público, reflete-se diretamente na recepção de seus textos literários. No seguinte excerto, em que Margarida Cardoso faz ressonância às palavras de José-Augusto França, fica evidente essa confluência estabelecida entre o autor e sua obra:

Como diz José-Augusto França, 'a antinomia salta aos olhos' quando a par da graça e da ironia de Garrett colocamos o vulto severo [de Herculano] e o pessimismo, ora sarcástico, ora liricamente sombrio, deste 'homem consciência', erigido num quase 'herói mítico do liberalismo português'. (CARDOSO, 2003, p.141)

A História da Literatura Portuguesa de Teófilo Braga, publicada pela primeira vez em 1870, cronologicamente próxima, portanto, do Romantismo, apresenta, ainda mais radicalmente, a relação entre esse "herói mítico do liberalismo português" e sua produção literária. Braga dedica uma extensa parte de sua História a Alexandre Herculano, abarcando sua produção literária, histórica, jornalística, e dando, também, grande destaque à sua atuação pública. Embora seja uma importante referência para o estudo do Romantismo português - sendo por isso retomada ao longo desse trabalho - , 
a obra de Teófilo Braga, entretanto, retrata Herculano de forma bastante tendenciosa. Apontando o escritor como o grande símbolo intelectual português de todos os tempos e ressaltando a absoluta confiança nele investida por toda uma geração, Braga declara sua frustração pelo não cumprimento das inúmeras expectativas que lhe teriam sido depositadas, como se pode observar no seguinte trecho:

Em que serviu Herculano a sociedade portuguesa, que tanto precisava de impulso para se reorganizar desde que entrou no regime do parlamentarismo? Revocou-a ao seu passado, falou-lhes dos frades, falou-lhes das resistências heróicas contra os mouros da fronteira, falou-lhe do cavalheirismo dos capitães da África, enfim, inspirou-lhe o patriotismo negativo, que arredava o espírito público da corrente de idéias modernas. Em vez de proclamar a necessidade do conhecimento da renovação filosófica que se operava na Europa em 1832, esterilizou-nos na contemplação de um cristianismo pessoal, meio poético, meio heterodoxo [...]. Chegou a ter o máximo de poder espiritual sobre a nação portuguesa, mas não soube usá-lo para dirigir uma época. (BRAGA, s.d., p.288)

Esse tom de desencanto e contrariedade prevalece em quase todo o texto de Teófilo Braga, tornando sua crítica à obra de Herculano contaminada pela decepção em relação ao homem público. Causa estranhamento, também, o fato de Braga, em uma obra que se destina ao estudo da história da literatura portuguesa, debruçar-se com tanta acuidade sobre os textos históricos de Alexandre Herculano e apresentar em uma perspectiva tão apressada sua produção literária. O privilégio dos elementos históricos da obra de Herculano, possivelmente, deveu-se ao fato de esse material prestar-se mais facilmente às críticas progressistas de Teófilo Braga. Ou seja, o passado medieval, retratado por Alexandre Herculano em sua História de Portugal - mas, também, em diversos textos literários - constituía-se, exatamente, daqueles elementos apontados por Braga como detonadores de um "patriotismo negativo".

Pelo menos uma dessas críticas, apontadas pelo autor em relação à 
historiografia de Herculano, foi refutada por Hernâni Cidade, que chama a atenção para o fato de que o crítico, ao censurar o curto período histórico retratado por Herculano até Afonso III -, tenha sustentado suas denúncias em fontes questionáveis, pois Hammer e Dozy, assim como Thierry, apontados por Braga como fontes seguras para Herculano, publicaram suas obras após a edição do I volume da História de Portugal (CIDADE, 1947, 112).

Mas, para além das discordâncias, entre o positivismo de Teófilo Braga e a historiografia e literatura romântica de temática medieval de Herculano, que, certamente, levaram a uma análise viciada da obra do escritor, uma questão ainda mais grave nos chamou a atenção: a absoluta ausência de qualquer referência a $O$ Bobo na História da Literatura Portuguesa de Braga. Se, como dissemos, os textos literários de Herculano parecem ser menos retratados que sua História, vários poemas e, principalmente, os romances, ou novelas, de cunho histórico ganham alguma visibilidade, na medida em que abordam temas e ideologias confrontados por Teófilo Braga. E, com menor destaque, ou simplesmente em breves menções, todo o restante da obra literária do autor, excetuando-se $O$ Bobo, é referido na História da Literatura de Braga.

A estranheza do fato, entretanto, conjuga-se com diversos outros casos de omissões em relação a essa obra de Alexandre Herculano. Como vimos, a recepção das obras literárias do autor encontra-se muitas vezes reduzida às expectativas públicas que se tem desse "homem-consciência". Mas, a exemplo do que foi visto na História da Literatura Portuguesa de Teófilo Braga, o que nos parece o caso mais evidente da análise tendenciosa e lacunar prestada a sua obra pode ser verificado nas escassas e incompletas apreciações de $O$ Bobo. Publicada primeiramente nas páginas de $O$ 
Panorama, em 1843, essa obra contou, durante a vida do escritor, apenas com uma edição brasileira em volume, não autorizada, de 1866. Esse fato, talvez, possa explicar parcialmente a ausência de referências a $O$ Bobo por Teófilo Braga. Mas, ainda assim, sabendo-se da repercussão positiva causada pela obra, na época de sua publicação em periódico, 1843, contando, posteriormente, até mesmo com uma contrafação brasileira, essa ausência causa, de fato, alguma perplexidade.

Somente em 1878 foi, então, publicada uma edição póstuma, que estaria sendo revisada por Herculano no final de sua vida. Considerando-se a imediata aceitação pública que teve $O$ Bobo e, ainda, que outras obras do autor, também publicadas na revista $O$ Panorama, foram rapidamente editadas em volume, é bastante intrigante a aparente negligência editorial em relação à obra. No texto, "Alexandre Herculano: malhas da história, armadilhas da ficção", Paulo Motta Oliveira (OLIVEIRA, 2000) chama a atenção para esse estranho fato e, também, para a ausência de referências à inusitada trajetória editorial de $O B o b o$, tanto nos dicionários literários, como em histórias da literatura. A inexistente problematização sobre a questão editorial já parece sugerir um descaso referente à própria obra.

Mas, se, de maneira geral, o conjunto da obra de Herculano teve um considerável acolhimento pela crítica, a deficiente recepção de $O$ Bobo, talvez, possa ser entendida pelas dissensões entre essa obra e alguns parâmetros designados para descrever a produção literária, histórica e jornalística do autor. Como foi visto anteriormente, a análise literária de suas obras não puderam se furtar à forte personalidade pública desse "homem legendário" (BRAGA, s.d., p.162), que, conforme ressalta, abaixo, Eduardo Lourenço, conquistou uma dimensão histórica, atuando diretamente na reformulação da nacionalidade portuguesa: 
Almeida Garrett e Alexandre Herculano foram dois admiráveis indivíduos. Tão indivíduos que cada um deles traçou um novo Portugal a sua imagem. Embora não se contradizendo, essas imagens reestruturaram, pela primeira vez, o imaginário português, fora do cânone - ou cânones - do nosso ideário nacional [...] (LOURENÇO, 1999, p.107)

Algumas questões apresentadas em $O$ Bobo parecem-nos, mesmo, incompatíveis com essa dimensão mítica atribuída a Alexandre Herculano, e com todo o peso ideológico, político e exemplar, comumente, confiado ao conjunto de sua obra. Distinguimos como ponto de maior atrito, entre as expectativas mais tradicionais relativas ao autor, e a narrativa de $O$ Bobo, a irreverência e ironia determinantes de um descompromisso histórico revelado ao longo do texto. Reforçando o impacto do descomprometimento moralizante ou didático, que apresenta-se em diversos aspectos da narrativa, como veremos a seguir, a obra retrata justamente um momento crucial da história de Portugal, como destaca, abaixo, Paulo Motta Oliveira, comparando-a com outros textos do autor:

Mas, em $O$ Bobo, temos uma diferença importante, que provocará alguns desdobramentos significativos: não estamos diante de uma região periférica, mas no próprio epicentro de uma crise que terá, como conseqüência, a batalha de $S$. Mamede e a futura criação de Portugal enquanto reino independente. E será justamente a gestação do reino de Portugal um dos temas centrais deste romance [...] (OLIVEIRA, 2000, p.142)

A importância histórica atribuída a esse período poderia, também, ser verificada na própria forma como Herculano e outros historiadores oitocentistas identificam aí a verdadeira gênese nacional. De fato, Alexandre Herculano, além de refutar a continuidade entre os antigos Lusitanos e os portugueses, aponta na Idade Média, mas especificamente no século XII, o início da nação portuguesa: "A vida nacional começa no século XII. Portugal é, nas palavras de Herculano, uma "nação 
inteiramente moderna". (MOREIRA, 2005, p.48). Também Oliveira Martins, na mesma linha de Alexandre Herculano, acredita que Portugal não teve uma "base etnogênica" e, para além dos latinos, celtas, lusitanos e moçárabes, a nação portuguesa teria se iniciado no século XII com os portugueses. (MARTINS apud MOREIRA, 2005, p.50).

Mas, se como foi visto, diversos indícios confluem para o desacordo entre a narrativa tão peculiar de $O$ Bobo e a crítica estabelecida em torno de seu autor, há, ainda, um fator incisivo para conformação de tal situação: a concentração da crítica e do público leitor em torno de Eurico, o presbítero. De fato, como veremos adiante, essa obra de Herculano absorveu de tal forma as atenções, desde o contexto de sua publicação até hoje, que a recepção de todo o restante de sua obra literária passou a ter em Eurico um parâmetro incontornável.

Por considerarmos um tanto viciosa grande parte da apreciação crítica assim constituída, e com intuito de realizarmos análises mais imanentes relativas à figuração do mouro, paralelamente aos aspectos estruturais e conteudísticos, em cada uma das narrativas históricas abarcadas nessa pesquisa, decidimos iniciar nossa abordagem à obra herculaniana, exatamente, com $O$ Bobo. A luz dessa narrativa pouco explorada e que traz questões bastante instigantes, como veremos a seguir, pretendemos revisar algumas perspectivas já cristalizadas, especialmente aquela que prescreve a exemplaridade do passado medieval, constituída pelo modelo heróico atribuído à conjunção entre o indivíduo e a nação.

Assim, no seguinte tópico, buscaremos analisar essa narrativa, abrangendo seus aspectos estruturais e temáticos, com intuito de traçar uma relação, entre o elemento mouro aí retratado e os demais componentes da obra. Em seguida, analisaremos os outros dois romances do autor e em seguida alguns contos de Lendas $e$ 
Narrativas, que contemplam a temática moura.

Salientamos, finalmente, que o nosso objetivo não implica a substituição de um paradigma crítico generalizante por outro, extraído da narrativa de $O$ Bobo. O que pretendemos, de fato, é, considerando especificamente a figuração do mouro, analisar questões importantes das ficções históricas de Alexandre Herculano, que haviam sido negligenciadas por não se adequarem a determinados padrões críticos. Para isso, contaremos com um parâmetro crítico inovador, que será melhor definido no seguinte tópico, pela análise de $O$ Bobo, o qual se distancia da perspectiva laudatória geralmente identificada em Eurico. 


\section{II.2 - O Bobo: descompromissos e omissões}

Conforme sintetiza António José Barreiros, a ação narrativa de $O$ Bobo abrange dois contextos, um político, outro amoroso, que acabam por se entrelaçar:

A trama do romance é constituída pelas dissensões entre D. Afonso Henriques e sua mãe e passa-se no Castelo de Guimarães, na primeira metade do século XII. Paralelamente a este enredo de caráter político e guerreiro, desenrola-se uma intriga amorosa que tem por centro o coração de uma jovem fidalga [Dulce], vassala de D. Teresa. (BARREIROS, 1989, p.85)

D. Teresa, filha de Afonso VI, rei de Leão e Castela, e viúva de D. Henrique, depois de envolver-se com Fernando Peres, o Conde de Trava, entra em conflito com seu filho, D. Afonso Henriques, culminando na Batalha de São Mamede. Paralelamente a isso, constitui-se uma trama amorosa envolvendo a filha adotiva de D. Teresa, Dulce, Egas Moniz Coelho, partidário de Afonso Henriques e Garcia Bermudes, amigo de Fernando Peres, ambos apaixonados pela nobre órfã, adotada pela infanta. É patente, desde o início, o amor de Dulce por Egas Moniz, enquanto por Garcia Bermudes ela sente apenas um carinho fraterno. O Conde de Trava, entretanto, força a moça a casar-se contra a vontade com Bermudes, sem que ele próprio saiba da chantagem a que foi submetida Dulce. Como em outras obras de Herculano, esse intrincado triângulo amoroso tem um final bastante nefasto.

Enquanto isso, a disputa política entre mãe e filho, ou, mais propriamente, entre D. Afonso Henriques e Fernando Peres, permeada por conchavos, traições e planos engenhosos, ganha uma personagem ficcional bastante irreverente, cuja associação à causa do infante se dá apenas por conta de uma vingança pessoal: “[...] o truão D. Bibas -, que odeia o Conde de Trava e os seus partidários, porque deles 
recebera humilhações afrontosas, depois de ter gozado de favor na corte de D. Henrique." (CARDOSO, 2003, p.180). De fato, conforme salienta Margarida Cardoso, justificando-se o título da obra, o bobo, está realmente no centro da trama política e também daquele contexto amoroso, apresentado acima (CARDOSO, 2003, p.180). E, realmente, os conflitos entre as duas facções - a dos seguidores de D. Afonso Henriques, que contava com Egas Moniz e Gonçalo Mendes da Maia, entre outros, e a de Fernando Peres, que tinha entre os muitos sectários, Garcia Bermudes - foram acompanhados e até mesmo conduzidos pela presença furtiva de D. Bibas, conforme descreve abaixo, Margarida Cardoso:

\begin{abstract}
Naturalmente partidário do Infante, o truão habita, no castelo, um antro onde achara uma esquecida passagem para o exterior; e, sumido por cantos e escuridões, surpreende conversas, penetra em segredos. É o que o torna capaz de resolver situações-chave do romance: conhecedor do regresso de Egas, da aproximação do exército do Infante, das preocupações de Gonçalo Mendes da Maia e da cilada que Fernando Peres lhe prepara (dando a Garcia Bermudes a ordem de encerrar as portas de Guimarães para que guerreiro tão valoroso não pudesse ir, com as suas gentes, reunir-se ao Infante), D. Bibas utiliza a passagem secreta da sua toca para se vingar do Conde de Trava, obviando-lhe todos os planos: promove a saída de Gonçalo Mendes e dos seus, liberta Egas da masmorra onde Fernando Peres o encerra à espera da forca, [...] faz penetrar no interior do castelo as tropas do Lidador, já no decurso da decisiva batalha entre mãe e filho. (CARDOSO, 2003, 180)
\end{abstract}

Da mesma forma, a intriga amorosa, tem também a intervenção do truão, que coloca-se, desde o início da narrativa, ao lado de Dulce e Egas, promovendo ainda o embate entre Egas Moniz e Garcia Bermudes, na batalha de S. Mamede, conforme se pode, novamente, acompanhar pelas palavras esclarecedoras de Margarida Cardoso: 
Convencendo Egas e evadir-se do cárcere para se dar ao prazer da vingança (o jovem soubera ter Dulce desposado Garcia Bermudes, porque Fernando Peres enganosamente lhe prometera, sob tal condição, a vida do trovador), o truão fica também ligado ao desenlace trágico da história amorosa, pois dá azo a que Egas e o aragonês se confrontem, durante a batalha de S. Mamede, num feroz duelo que aquele vence, matando o rival. No mosteiro para onde é levado o cadáver de Garcia, Dulce morre de angústia não resistindo ao escárnio de Egas, à ira com que ele recusa perdoar ao aragonês o mal causado (mal involuntário, porque o nobre Garcia Bermudes só aceitara desposar Dulce depois de julgar, por artes de Fernando Peres, que a jovem anuíra sem contrições ao matrimônio) e à profissão monástica do cavaleiro-trovador; três dias depois, o noviço aparece morto sobre a sepultura da jovem, deixando a lousa coberta de trovas. (CARDOSO, 2003, p.181)

Assim, o importante recorte histórico abarcado em $O$ Bobo, no qual se situa a origem da nação portuguesa, será conjugado com uma trama ficcional composta por personagens complexas e ambíguas que ultrapassam limitações didáticas e maniqueístas. Considerando-se uma polaridade inicial, estabelecida entre o Conde de Trava e D. Teresa, por um lado, e Afonso Henriques, por outro, na qual se poderia antever uma dicotomia entre os interesses asturo-leoneses e aqueles, especificamente, portugueses, torna-se impossível, entretanto, determinar uma identificação absoluta entre a causa portuguesa e um padrão heróico de comportamento. Da mesma forma, o partido de D. Teresa não pode, também, alinhar-se, de forma muito simplista, apenas com as ações indignas, como veremos adiante.

Margarida Cardoso, em uma análise breve, mas bastante interessante, sobre a obra, alude também algumas das diversas variáveis que concorrem para que a narrativa ocupe um lugar de destaque na produção de Herculano, acentuando, particularmente, as divergências em relação a Eurico, como se pode acompanhar abaixo: 
[...] a ação de $O$ Bobo é [...] complexa, suscitando, ao invés do que acontece em Eurico, uma variada gama de tons, que vai da concreteza descritiva (o Castelo de Guimarães, o ambiente de um sarau, o cenário de uma masmorra são cuidadosamente reconstituídos, com recurso a um léxico referente a "coisas" antigas) à solenidade melodramática [...], à vivacidade coloquial [...] e mesmo à trivialidade galhofeira. Com esta polivalência estilística do romance, pedida pela representação de matéria ora elevada, ora "vulgar", se coaduna a freqüente irrupção pessoalizada de um Narrador que interpela o Leitor, acentuando paralelos entre passado e presente e brincando muitas vezes com a própria construção da narrativa. (CARDOSO, 2003, p.181)

A ausência de uma perspectiva laudatória no tratamento desse importante marco histórico da nacionalidade portuguesa já foi apontada por Teófilo Braga na própria forma como Herculano retrata o fato em sua História de Portugal:

Assim para Herculano, a desmembração de Portugal da unidade momentânea asturo-leonesa é incompreensível, porque ora a atribui ao conde D.Henrique, aos planos superiores com que defende D.Teresa pela perspicácia política, e a seu filho D. Afonso Henriques, ora crê nas forças imanentes ao próprio condado, que motivaram a sua desmembração. (BRAGA, s.d., p.238)

Se, como vimos acima, Braga critica Herculano por não compreender

claramente o fato histórico referente à desmembração portuguesa, acusando o historiador de apontar aleatoriamente os protagonistas desse evento, podemos acompanhar, abaixo, nas palavras do próprio Herculano sobre o assunto, uma versão um pouco divergente do que foi constatado por Teófilo Braga:

[...] o pensamento de desmembração e independência, que é visível existia já nos ânimos de Henrique e da sua viúva e que veio a realizarse completamente no tempo de Affonso Henriques, é um pensamento comum ao chefe do estado e aos membros dele, sendo talvez os atos dos príncipes ainda mais o resultado da influência do espírito público do que a manifestação espontânea da própria ambição. Os documentos dos primeiros anos em que regeu Portugal Afonso Henriques, concordes com os da época de D.Theresa, tendem a confirmar esta suspeita. (HERCULANO, sd, p.73) 
A argumentação de Alexandre Herculano não parece refletir uma incompreensão sobre tal questão, e sim, um ponto de vista, bastante consciente, a partir do qual o historiador conclui que não houve uma única personalidade responsável pela desmembração portuguesa, mas um encadeamento de fatores e vontades que culminaram com o fato. Como se pode notar, Herculano atribui a realização do evento, tanto ao conde Henrique, como à D. Teresa, ao infante Afonso Henriques e, ainda mais, à "influência do espírito público".

Ressaltando, então, o paralelismo entre a postura de Alexandre Herculano como historiador e aquela apresentada como ficcionista de $O B o b o$, no que se refere à batalha, ou aos antecedentes da batalha, de S. Mamede, poderíamos ir mais longe, e identificar em D. Bibas uma personificação daquele "espírito público" de que fala o autor em sua História de Portugal. Paulo Franchetti já havia destacado a função alegórica, também apontada por outros autores, que estaria por trás do bufão de Herculano:

É também, como já se notou, uma representação do povo oprimido pelo despotismo feudal, que o autor apresenta exercendo a vingança por anos e anos de opressão em uma ação plena de conseqüências políticas para a nação portuguesa. (FRANCHETTI, 1997, p.6)

Atentamos, mais uma vez, para o caráter irreverente dessa obra de Alexandre Herculano, que destituindo o passado português de uma fundamentação heróica, deposita na criação ficcional de um bobo da corte, que poderia representar o próprio povo oprimido, a responsabilidade pela origem da nação portuguesa. Se analisarmos a bizarra caracterização de D. Bibas, “[...] um vulto de pouco mais de quatro pés de altura; feio como um judeu; barrigudo como o cônego de Toledo; imundo como a consciência do célebre arcebispo de Gelmires; e insolente como um vilão de 
beetria." (HERCULANO, 1997, p.23), fica ainda mais evidente a predominância do tom sarcástico da obra em detrimento das poucas considerações reverentes ao fato histórico retratado. Pode-se até mesmo depreender-se da narrativa de $O$ Bobo que, através da vingança do truão, a independência de Portugal teria se dado por influência de belzebu, conforme sugere o seguinte trecho:

Mas como vingar-se? Ignorava-o. Juraria, contudo, que Belzebu lhe dizia ao ouvido: 'Pensa bem; que hás de atinar com o caminho que buscas'. Quem deixou de achar meios neste mundo para satisfazer paixões más? (HERCULANO, 1997, p.102).

Percebemos, assim, uma grande discrepância entre o padrão moralizante, heróico, cristão e exemplar como a crítica costuma definir a ambientação histórica medieval das narrativas de Herculano, e a prevalência de uma atitude anárquica, descomprometida com ideologias, religiões e mesmo com a própria história, observada na narrativa de $O$ Bobo.

Mas, até mesmo parte da crítica, que parece ter uma leitura mais criteriosa dessa desconcertante obra de Alexandre Herculano, deixa-se levar, em alguns momentos, por generalizações redutoras, que eliminam aspectos essenciais da narrativa. João Gaspar Simões, por exemplo, embora refira-se a $O$ Bobo como uma obra-prima, acrescentando ainda: “Tal como está, $O$ Bobo é o nosso romance histórico mais perfeito [...]" (SIMÕES, 1969, p.36), ao referir-se a diversas obras de Herculano, entre as quais $O$ Bobo, faz a seguinte colocação:

Nestas obras o elemento histórico funde-se com o elemento romanesco propriamente dito, e este sacrifica ao folhetinesco o psicológico. Em obediente ao imperativo do folhetim, as personagens ou amam ou odeiam, ou são covardes ou heróicas, ou atraiçoam ou sacrificam-se. De uma só peça e de um só parecer, a rigidez moral é o seu traço dominante. (SIMÕES, 1969, p.32) 
Concordando com Simões no que diz respeito ao notável valor de $O$ Bobo, discordamos, entretanto, em relação àquilo que nos parece um dos traços mais significativos para a apreciação dessa obra: a ambiguidade das personagens. É, exatamente, na quebra da perspectiva maniqueísta, descrita acima por Simões, que distinguimos a complexidade de algumas personagens, caracterizadas por uma gama de nuances que lhes conferem um impressionante grau de humanidade.

Um dos exemplos dessa heterogeneidade de caracteres pode ser verificado na forma como é apresentada a mãe de D. Afonso Henriques, D. Teresa. Comparamos, abaixo, o retrato absolutamente horrendo como a infanta é pintada por Luís de Camões, com os contrastes de uma personalidade forte, arguta, mas, ao mesmo tempo, frágil e submissa, traçados por Herculano:

De Guimarães o campo se tingia Co sangue próprio da intestina guerra, Onde a mãe, que tão pouco o parecia, A seu filho negava o amor e a terra. Co ele posta em campo já se via; E não vê a soberba o muito que erra Contra Deus, contra o maternal amor; Mas nela o sensual era maior. Ó Progne crua, ó mágica Medeia, Se em vossos próprios filhos vos vingais Da maldade dos pais, da culpa alheia, Olhai que inda Teresa peca mais! Incontinência má, cobiça feia, São as causas deste erro principais: Cila, por hua, mata o velho pai; Esta, por ambas, contra o filho vai.

(CAMÕES, 19--, p.118 - 119)

Nota-se que, para Camões, a infanta, destituída de qualquer sentimento materno, seria pior, mesmo, que Medéia, mulher que matou os próprios filhos para vingar-se do adultério de seu marido. Alexandre Herculano, entretanto, adivinha por trás da infâmia da amante de Fernando Peres o sofrimento da mãe de Afonso Henriques. D. 
Teresa é representada por Herculano sob pelo menos três perspectivas distintas: como uma mulher forte, astuta e de ânimo viril (HERCULANO, 1997, p.17); como a esposa submissa de Fernando Peres, e, ainda, como mãe legítima de Afonso Henriques e adotiva de Dulce, pelos quais nutre um sincero afeto materno. Tal sentimento, evidenciado, ainda mais, em sua relação com a herdeira dos Bravais, é limitado, entretanto, pela forte influência do conde de Trava sobre a infanta.

Seguem-se algumas situações conflituosas determinantes das ambiguidades percebidas nessa personagem. O seguinte comentário destaca, exatamente, o sentimento genuíno da infanta por Dulce e, por outro lado, a relação perniciosa com Fernando Peres, que compromete a manutenção daquele afeto maternal: "Dolorosa era a situação de D. Theresa. Amava sinceramente Dulce; mas entre ela e o conde havia laços que não podia, que não quisera quebrar.” (HERCULANO, 1997, p.93). Nas citações, abaixo, são também apresentados os conflitos oriundos dos impulsos maternais, passionais e autoritários, confluentes na composição dessa complexa personagem:

D. Theresa, que desde a partida de seu filho se mostrara triste, abatida e irresoluta, parecia nesta noite reassumir toda a sua antiga energia. No seu rosto, banhado de uma alegria um tanto forçada, conhecia-selhe o desejo de que lhe cressem o ânimo tranqüilo ao aproximar da procela. (HERCULANO, 1997, p.81)

[...] D. Theresa esqueceu-se de que era mãe, esqueceu-se da altivez e dureza de Fernando Peres, para se lembrar só de que era amante e rainha, e de que mais de uma vez o som da sua voz tinha bastado a infundir ousadia invencível no ânimo de seus guerreiros. (HERCULANO, 1997, p.147)

Refletindo as diversas paixões que alimentam seu ânimo, as atitudes da infanta também oscilam, ao longo da narrativa, impedindo uma delimitação simplista do caráter da personagem. Observa-se, então, a impossibilidade de associar-se, de forma 
imediata, aquela que seria a antagonista da causa portuguesa, a uma configuração totalmente maléfica de comportamento.

Um personagem, apenas, aparenta assumir, plenamente, o papel de vilão do conflito apresentado em $O$ Bobo: Fernando Peres, o conde de Trava. A culpabilidade da rainha, pelas atitudes contrárias ao seu próprio filho, parece deslocar-se para a inesgotável conta de vilezas praticadas pelo conde, que, como vimos, exerce grande influência sobre suas decisões.

Por outro lado, a incipiente dicotomia entre bem e mal, que teria em Fernando Peres a personificação deste segundo pólo, desorganiza-se, rapidamente, quando consideramos a figura de Garcia Bermudes, o melhor amigo do Conde. O caráter corajoso, nobre e generoso como é descrito Bermudes, ao longo de toda a narrativa, é exemplificado, principalmente, em sua negação de submeter Dulce, a mulher que amava, a casar-se com ele contra vontade. Realmente, se um tênue delineamento entre bem e mal, distingue o partido dos seguidores de Afonso Henriques daqueles que apóiam o conde de Trava, verifica-se, entretanto, que a exaltação das características morais de Garcia Bermudes faz com que o personagem se acomode mal ao pólo antagonista da trama.

Ocorre, inclusive, uma complicação no final da narrativa, em que se percebe que, para Dulce, a atitude de Garcia Bermudes teria sido mais honrosa que a de Egas Moniz, cavalheiro amado por ela, e que, em uma visada mais generalizante, poderia ser entendido como o herói da narrativa. Dulce, ao saber que Egas matara Bermudes, que era, então, seu marido, e ainda, de forma cruel e sarcástica, apresentava-lhe o corpo, lhe dirige as seguintes palavras: 
Turbaste essa imagem com o lodo de um assassínio: com a tua primeira covardia. Posso agora morrer. Só te peço que te afastes para te eu não ouvir nem ver... Deixa-me expirar abraçada com a memória do passado, com a lembrança do nosso amor inocente; deixa-me até o fim amar o meu Egas; deixa-me esquecer de ti, que não és já ele! (HERCULANO, 1997, p.151)

Assim, o inusitado triângulo amoroso formado por Dulce, Egas Moniz e Garcia Bermudes, constituído de ambiguidades de sentimentos e de uma relativa equivalência moral entre os envolvidos, impede uma solução óbvia para a justa determinação de um par romântico. João Gaspar Simões também atenta para a questão, destacando a complexidade de sentimentos de Dulce em relação a Egas Moniz e a Bermudes:

[...] Dulce, a mais humana das criações femininas de Herculano. Ao pé dela, Hermengarda empalidece. Nesta, a paixão é metafísica, simbólica. Naquela há realidade, há força humana. Dir-se-á que ama dois homens ao mesmo tempo, e que a um, Egas Moniz Coelho, sacrificaria o outro, se não tivesse de sacrificar os dois - Garcia Bermudes e Egas Moniz Coelho - à morte que a reclamava virgem e pura. Assim o exigia a medida ideal do romance histórico, que resistia ainda às solicitações do real, escopo último da literatura de ficção dos tempos modernos. (SIMÕES, 1969, p.37)

Além de toda a sutileza das nuances e contradições que envolvem os personagens, promovendo um grau de complicação inesperado para a trama narrativa, outro fato concorre para a diluição da organização maniqueísta da obra: o modo como são retratados os mouros. A figuração desses elementos ocorre aqui, geralmente, de duas formas: de maneira individualizada, através dos personagens mouros, Abul-Hassan e Martim Eicha, e, também, em referências pouco precisas à coletividade muçulmana, seja nas terras portuguesas ou no ultramar. Neste caso, funcionando quase como um pano de fundo, são aludidas, entre outros temas, as lutas entre cristãos e muçulmanos, mas apenas como parte da composição do cenário medieval referente ao XII século. Um 
dos exemplos desse tipo de referência pode ser acompanhado na seguinte citação:

Era principalmente nos assédios, quer defendendo-se, quer acometendo, que os árabes conheciam todo o preço da própria superioridade intelectual. As suas máquinas de guerra, mais perfeitas que as dos nazarenos, não só pela melhor combinação das forças mecânicas, como pela maior variedade de engenhos e invenções, davam-lhe notáveis vantagens sobre a grosseira tática dos seus adversários. (HERCULANO, 1997, p.20)

Tal descrição que expressa o reconhecimento pela tecnologia de guerra dos árabes como sendo bem superior a dos cristãos, falando-se inclusive de uma "superioridade intelectual" daqueles, não é um caso isolado na narrativa de $O$ Bobo. Da mesma forma, apresentam-se, também, outras referências elogiosas aos povos árabes, particularmente no que diz respeito ao seu conhecimento sobre agricultura, como em determinado trecho no qual se descreve "um terrado coberto de flores e arbustos viçosos", que seria mantido, nas palavras do narrador, graças a "um desses engenhos árabes, que ainda hoje cobrem o solo da Península e fertilizam as nossas veigas e pomares [...]” (HERCULANO, 1997, p.59).

Mas, há ainda algumas alusões aos combates entre cristãos e muçulmanos na Palestina, uma das quais retrata, por exemplo, a amizade selada, nesse contexto, entre Garcia Bermudes e Fernando Peres: "Garcia salvara o conde em certo recontro [...] da multidão de sarracenos que o cercavam. Desde então, companheiros de perigos e deleites, nunca mais se haviam separado. Era uma dessas fraternidades de armas [...]" (HERCULANO, 1997, p.48). Também, ao final da narrativa, uma referência ao destino de Gonçalo Mendes da Maia poderia exemplificar as diversas alusões à heroicidade dos cavaleiros cristãos, como Egas Moniz entre outros, obtida pelas vitórias nas lutas contra ou mouros: "Gonçalo Mendes tornou-se cada vez mais famoso por inauditas façanhas contra a mourisma [...]" (HERCULANO, 1997, p.152). 
Já a seguinte citação apresenta uma das referências mais incisivas, apresentadas na narrativa, no que concerne à injusta relação entre cristãos e mouros. Herculano dá voz a um muçulmano, Abul-Hassan, personagem secundário, responsável pelo jardim pênsil do palácio ${ }^{4}$, que, em um discurso bastante coerente dirigido a Egas Moniz, acusa os excessos de violência e a falta de justificativa racional daqueles que, em nome do cristianismo, vão para África "caçar mouros”, cometendo grandes atrocidades:

Posto que o ódio contra os meus irmãos - respondeu sorrindo o árabe - vos levasse tão longe para lhes derramar o sangue, como se vos não bastasse o dos muslins da Espanha, nem por isso vos perdi a afeição, porque sei por experiência que ao menos não seríeis cruel para com os vencidos, como são quase todos os guerreiros cristãos. (HERCULANO, 1997, p.71)

$\mathrm{Na}$ verdade, Abul-Hassan, se alinharia, indiretamente, a causa de Afonso Henriques, devido a uma relação antiga que mantinha com Egas Moniz. Mas, embora ele chegue a viabilizar o plano dos seguidores do príncipe, promovendo o acesso ao castelo, da mesma forma que, em tempos remotos, ele favorecia os encontros entre Dulce e Egas Moniz, sua motivação, entretanto, aparente ser, principalmente, financeira. Outro personagem de origem árabe tem, também, uma representação bastante interessante, pontuada, de forma irregular, ao longo da narrativa: o cônego de Lamego, Martim Eicha, tornado o capelão de D. Teresa. Filho de um muçulmano, váli de Lamego, Martim Eicha, da mesma forma que seu pai, converte-se ao cristianismo. As referências a esse personagem são, desde a sua introdução, um tanto irônicas, como se pode acompanhar no seguinte excerto:

\footnotetext{
4 “Abul-Hassan, cativo em uma arrancada, obtivera pela sua ciência agronômica não só um tratamento menos duro do que era usual entre os cristãos para com os servos, mas até por fim a liberdade, e com a liberdade um cargo que se casava com a sua educação e hábitos - o de jardineiro do horto pênsil." (HERCULANO, 1997, p.72)
} 
[...] como em todas as opiniões desse mundo os renegados são os mais fervorosos na sua nova crença, achara ele em consciência que para se mundificar das torpezas do islamismo devia abraçar a pura vida do sacerdócio. (HERCULANO, 1997, p.35)

E, se como vimos anteriormente, as alusões, apresentadas pelo narrador, à coletividade árabe, são geralmente positivas, enfatizando-se, inclusive, sua "superioridade intelectual", é justamente na fala desse mouro convertido ao cristianismo, que se pode acompanhar a expressão de desprezo pelos mouros, habitantes da África, e, principalmente, pelo islamismo. Tal situação evidencia-se no seguinte excerto, em que Martim Eicha, dirigindo-se a Gonçalo Mendes da Maia, critica as ações de Afonso Henriques contra a própria mãe e, também, contra o Conde de Trava, defendo que ao invés de tais procedimentos o Infante deveria combater os "malditos ismaelitas" na África e na região sul do país:

É lástima: é na verdade lástima! Não me sofre o ânimo ver assim um moço ambicioso e louco desacatar com armas rebeldes sua mãe, sua senhora. Largo campo à cobiça de honra e domínios, se pretende ganhar nome e poder, se lhe abre em terras de infiéis. Se tem sede de sangue, derrame o sangue dos malditos ismaelitas, moabitas e agarenos. Os campos do sul aí estão patentes à ambição dos ousados. Que vão devastar as searas dos mouros, derrubar as suas povoações e castelos, incendiar-lhes as mesquitas, onde diariamente se repetem as blasfêmias, torpezas e imundícies do abominável Alcorão. (HERCULANO, 1997, p.38)

Mas, o narrador revela, ainda, em um tom realmente sarcástico, a adequação de Martim Eicha para a função de capelão de D. Teresa. Conforme exposto ironicamente na narrativa, o cônego de Lamego entendia o Evangelho como um “palimpsesto do Alcorão" (HERCULANO, 1997, p.35), e aceitaria, sem restrições, a relação amorosa entre D. Teresa e Fernando Peres: 
A bela infanta de Portugal chamou-o à corte, apenas dela saiu desgostoso o arcebispo de Braga, cujo caráter austero malsofria os amores de Fernando Peres e de D. Theresa. Martim Eicha era o homem talhado para o caso. (HERCULANO, 1997, p.35).

Além da moralidade religiosa um tanto flexível e da atitude, extremamente, preconceituosa em relação aos muçulmanos, Martim Eicha apresenta, também, atitudes cruéis em relação a D. Bibas. Quando o bufão é açoitado pelos donzéis do Conde Fernando Peres e ele, então, recorre ao cônego de Lamego, solicitando sua intervenção, este responde da seguinte forma:

- Filho - respondeu Martim Eicha, fazendo um ademã entre hipócrita e de escárnio -, o castigo é muitas vezes caminho para o arrependimento. Resigna-te, meu filho. Se nisso não houvera vanglória, dir-te-ia que no sofrimento de injúrias podias aprender de mim a ser resignado. (HERCULANO, 1997, p.63)

O personagem segue sem grande destaque na narrativa, mas colocando-se sempre ao lado de D. Teresa e Fernando Peres, e, ao final da história, quando se descreve o destino dos personagens principais, já no penúltimo parágrafo, faz-se o seguinte comentário sobre o que teria, então, ocorrido com Martim Eicha:

O reverendo Martim Eicha voltou para a sé de Lamego, porque ninguém mais fez caso dele na corte, nem para bem, nem para mal. Lá comeu, bebeu, dormiu, rezou - umas vezes pelo Alcorão, outras pelo breviário. (HERCULANO, 1997, p.152)

Assim, seguindo o tom descomprometido da narrativa, também esse personagem, sem ideologia, religião ou moral, chega ao final da trama, da mesma forma como foi introduzido: alheio a qualquer princípio valorativo. Mas, cotejando a seguinte concepção extraída de $O$ Bobo, e que poderia também ser emblemática do pensamento herculaniano, com a caracterização desse personagem, parece-nos resultar daí um desacordo: 
Quando cumpria aplicar uma designação que representasse o habitante da parte da península livre do jugo do Islão, só uma havia: christianus. $\mathrm{O}$ epíteto que indicava a crença representava a nacionalidade. $\mathrm{E}$ assim cada catedral, cada paróquia, cada mosteiro, cada simples ascetério era um anel da cadeia moral que ligava o todo, na falta de um forte nexo político. (HERCULANO, 1997, p.15)

A postura aí apresentada por Herculano, que poderia, também, ser endossada, posteriormente, pela sua historiografia, como já foi apontado por diversos críticos, na qual a identificação de nacionalidade ou região seria apagada em nome da designação religiosa, não parece adequada à constituição do personagem fíctício, Martim Eicha. Assim como o irmão de Abul-Hassan, também um árabe convertido ao cristianismo, personagem inexpressivo, sequer nomeado, mas denominado insistentemente como tornadiço ou "árabe-cristão" (HERCULANO, 1997, p.105), Eicha é, também, demarcado, de forma incisiva, pela sua origem moura. A conversão ao cristianismo, que na verdade acontecera já com o seu pai, a atuação religiosa, como cônego e capelão, e, até mesmo, a aversão ao islamismo, não imunizaram o personagem de uma caracterização sempre imbuída do passado mouro. Nesse caso, também, como já foi visto, a conversão ao cristianismo não resultou em nenhum comprometimento moral ou religioso para o personagem.

Curiosamente, então, embora a narrativa apresente um reconhecimento pelo valor da cultura árabe, mais especificamente no que diz respeito ao conhecimento de técnicas agrícolas e, também, a sua engenhosidade bélica, sugerindo até uma superioridade intelectual em relação aos cristãos, apreende-se daí uma demarcação tão rígida entre mouros e portugueses que nem mesmo a conversão religiosa pode atenuar. Se o reconhecimento intelectual pelos povos de origem árabe é consonante com a perspectiva apresentada por Herculano em sua historiografia, como já visto anteriormente, a questão religiosa, nesse caso, entretanto, parece um tanto divergente. 
Como dissemos anteriormente, a partir de textos do próprio Alexandre Herculano e das críticas de Ana Rita Gaspar Moreira, entre outros autores, a religião, e não a etnia, seria, para o historiador, determinante tanto da moralidade quanto da civilização. Mas, pelo menos nos personagens convertidos da narrativa de $O$ Bobo, mais especificamente em Martim Eicha, a origem étnica prevalece sobre a conversão cristã. Assim, poderíamos apreender daí, a expressão, ainda que ficcional, de uma contundente delimitação étnica e não apenas religiosa.

Um outro aspecto de $O$ Bobo que corrobora o que temos discutido aqui sobre o descomprometimento dessa obra ante quaisquer valores rígidos de pensamento, diz respeito ao descaso e ironia em relação à verdade histórica. Não apenas um personagem cômico, o bufão, constitui-se como grande responsável pela origem da nação portuguesa, conforme destacado acima; mas, ainda, a história de Portugal, ou a história em si, é apresentada como estrutura lacunar, passível de preenchimentos fictícios, completamente arbitrários em relação aos fatos reais. Paulo Motta Oliveira destaca, abaixo, a importância e as implicações dessa questão para Alexandre Herculano, em sua função de autor da História de Portugal, obra que teria seu primeiro volume editado três anos após a publicação de $O$ Bobo:

Se a história é apenas uma recuperação parcial, se essa recuperação pode trazer uma face falsa do passado, podemos entender o quanto esse romance poderia ser perturbador. Afinal, Portugal poderia ter surgido não por grandes feitos, mas graças à vingança de um reles bobo. (OLIVEIRA, 2000, p.149)

Concluímos, desse modo, que a ausência de uma motivação didática e de um modelo heróico que sustentasse a origem portuguesa, assim como, a ambiguidade e sutileza com que foram retratados os personagens reais e fictícios e o questionamento relativo à própria veracidade da história, provocaram uma grande cisão entre $O$ Bobo e 
os aparatos críticos que descrevem, de maneira geral, a obra de Alexandre Herculano. Entendemos essas circunstâncias como determinantes das diversas formas de omissões a que tem sido submetida essa obra, desde o seu obscuro trajeto editorial. Fica ainda uma questão: seria, de fato, $O$ Bobo tão díspar em relação ao restante das produções literárias de Herculano, ou, de alguma forma, as outras obras do autor, por se prestarem mais facilmente às expectativas já estabelecidas pela crítica, não teriam sido compreendidas, de forma parcial, ficando ignorados os aspectos complicadores e disformes em relação a uma determinada padronagem? 


\section{II.3 - Eurico, o presbítero: oposição entre os bárbaros godos e}

\section{mouros}

\section{II.3.1 - Eurico, o presbítero: a marca de uma geração}

O alcance de público e o reconhecimento de Eurico, o presbítero poderiam ser atestados pelas inúmeras reedições da obra e pela influência declarada que exerceu em autores posteriores. Além de ser, sem dúvida, o texto literário mais conhecido de Alexandre Herculano, diz-se que sua popularidade encontra parâmetro equivalente, na Literatura Portuguesa, apenas na obra épica de Luís de Camões: “[...] obra mais célebre de Herculano, tendo obtido cerca de 50 edições, caso único juntamente com $O s$ Lusíadas de Camões" (BEIRANTE; CUSTÓDIO, 1977, p.6).

Em 1843, alguns extratos de Eurico foram já publicados em O Panorama e também na Revista Universal Lisbonense, e, em 1844, a obra foi editada em volume. A sua primeira crítica seria feita apenas em janeiro de 1845, por António Feliciano de Castilho, com expressão, de maneira geral, elogiosa, mas acrescida de algumas restrições. Nas palavras de Vitorino Nemésio, Castilho considera Eurico um livro "belo, mas moralmente perigoso" (NEMÉSIO, 1979, p.XXXIX). Entre outras razões, é provavelmente devido ao que se considerava ser uma perniciosa influência exercida nos jovens escritores, que o próprio Herculano, em 1875, ao comentar uma edição espanhola de Eurico faz a seguinte autocrítica, expressando algum desgosto pela obra: 
[...] de todos os meus filhos literários foi este sempre, apesar de primogênito, aquele a quem tenho tido menos afeto, porque lhe conheço os defeitos, e não o suponho inocente em certas más tendências que às vezes se revelam no estilo de alguns escritos de moços literatos. (HERCULANO apud FERREIRA, 1971, p.92)

O autor não revela exatamente quais seriam esses defeitos, mas uma hipótese a ser considerada diz respeito ao pessimismo que contagiará a literatura portuguesa, especialmente no que se refere ao plano estético do chamado ultraromantismo, conforme salienta abaixo Alberto Ferreira:

\begin{abstract}
Algumas das idéias-sentimentos expressas por Herculano terão funda repercussão estética do "segundo" romantismo. A representação simbólica de Eurico, poeta presbítero e poeta soldado, será a chave da geração de poetas que no ano de 1844 vão exprimir a sua mundivivência. O "triste vácuo da soledade do coração" atingirá mais ou menos a todos, e todos, mais ou menos, serão sensíveis ao "horrível espetáculo duma nação cadáver" [...] a arte nacional, após a frustração revolucionária de 1834 , e sobretudo depois da derrota de 1846-47, afundar-se-á no atoleiro do pessimismo amassado por Herculano e bem patente já n'A Harpa do Crente e n'A voz do Profeta. Mas são os poemas em prosa de Eurico que definem, no plano prático, as opções do chamado ultra-romantismo. (FERREIRA, 1971, p.92 - 93)
\end{abstract}

Vitorino Nemésio traduz, de forma precisa, na seguinte frase, a inexorável influência que, positiva e negativamente, tal obra de Alexandre Herculano exerceu sobre os intelectuais de sua época: "Formara-se, digamos assim, o "complexo de Eurico’, uma espécie de andaço da alma" (NEMÉSIO, 1979, p.LII). O que poderia ser complementado com as palavras de Júlio César Machado, retomadas, a seguir, por Margarida Cardoso: “[...] disse Júlio César Machado, na década ultra-romântica de 60, que Eurico não teve 'admiradores', mas “fanáticos”” (CARDOSO, 2003, p.178 - 179).

Poucos anos depois, entretanto, quando a chamada "geração de 70" apresenta uma perspectiva diversa sobre a literatura, ocorre uma inversão de tal receptividade, obsessiva e laudatória, prevalecendo uma sensação de incômodo pelo 
caráter “débil, sentimental e enfático" (NEMÉSIO, 1979, p.LIV) da obra. E, conforme esclarece Vitorino Nemésio, acontece um descompasso entre a apreciação da figura pública de Herculano, principalmente por Antero de Quental e Oliveira Martins, e "o silêncio elegante e irônico" (NEMÉSIO, 1979, p.LV) que Eça de Queirós, entre outros, guardariam sobre Eurico. E, uma crítica mais exaltada e ferrenha, pode ser encontrada em Teófilo Braga, mas Nemésio denuncia aí uma “opinião [...] viciada pela sua posição acrimoniosa e ressentida contra Herculano" (NEMÉSIO, 1979, p.LV).

\section{II.3.2 - Convergências temáticas: amor, história e guerra em}

\section{Eurico, o presbitero}

A dificuldade de análise da obra literária mais conhecida de Herculano inicia-se, entretanto, pela indefinição de seus aspectos formais, implicando em uma nomenclatura sempre problemática, a saber: romance histórico, novela, poema em prosa, entre outros. O próprio Alexandre Herculano, na primeira nota colocada em um texto introdutório à narrativa de Eurico, assume a dificuldade classificatória para essa obra:

\footnotetext{
Sou eu o primeiro que não sei classificar este livro; nem isso me aflige demasiado. Sem ambicionar para ele a qualificação de poema em prosa - que não o é por certo - também vejo, como todos hão de ver, que não é um romance histórico, ao menos conforme o criou o modelo e a desesperação de todos os romancistas, o imortal Scott." (HERCULANO, 1996, p.11).
}

João Gaspar Simões, por outro lado, localiza nessa indefinição exatamente o valor de originalidade da obra, salientando a autonomia do texto em relação aos 
modelos preestabelecidos:

Em verdade, ao contrário do que Herculano pensava, a sua 'crônicapoema' viria a constituir a prova real de seu talento de ficcionista, ou antes, do seu talento de poeta da história. Ao escrever o Eurico, escrevia uma das páginas mais originais da nossa novelística de todos os tempos. Fora dos moldes do romance histórico? Fora dos moldes do romance tout court. Mais perto da ficção que do poema, realmente, mas ficção-poema ainda, valha a verdade. (SIMÕES, 1969, p.32)

Embora divergindo de muitos críticos, a defesa de João Gaspar Simões da forma ficcional da obra, em detrimento (mas não recusa) da forma poema, nos parece acertada. Ainda que o todo da narrativa apresente um tom poético, os poemas, de fato, são uma parte menor inserida no texto, por isso nos parece bastante adequada a utilização do termo ficção-poema. Outras expressões, entretanto, como narrativa, narrativa-histórica ou texto ficcional, utilizados por outros críticos para referenciar a obra, nos parecem corretos, pois se não evidenciam a forma poética contida em partes do texto, também não excluem aspectos poéticos presentes ao longo de toda a narrativa.

Atentamos, finalmente, para as diversas ações e também descrições de caráter historiográfico, que perpassam grande parte da obra e acentuariam também sua feição de prosa. Maria de Fátima Albuquerque, por exemplo, destaca o aspecto excessivamente descritivo do texto de Herculano, dizendo que o autor "atinge a minúcia e, muitas vezes, excesso" (ALBUQUERQUE, 1999, p.70). A autora cita como exemplo o Capítulo I de Eurico, o presbítero, intitulado "Os Visigodos", em que se faz uma longa apresentação da História visigótica, nos seus aspectos de ascensão e queda”. (ALBUQUERQUE, 1999, p.70).

Mas, retomando a questão referente aos excessos sentimentais do romantismo, que tanto incomodaram a geração de Eça, Antero e Oliveira Martins, podem ser verificadas, de fato, expressões paradigmáticas de tais situações, no seguinte 
excerto, que traduz, com bastante precisão, a trama amorosa contida em Eurico, o presbitero:

\begin{abstract}
A ação, que tem como herói o gardingo-presbítero Eurico, passa-se no crepúsculo da civilização visigoda na Península Ibérica. No fundo, é uma biografia heróica dum cavaleiro apaixonado por Hermengarda, mas cujo amor se não consuma por oposição daquele que não chegaria a ser seu sogro. Eurico, num ato de impulsividade despeitada, fez-se sacerdote católico. Porém nunca conseguiu esquecer aquela que fora o sonho de sua juventude. Acontecimentos funestos para o domínio visigótico na Ibéria puseram Eurico em contato direto com Hermengarda, em circunstancias de todo dramáticas: ela, caída em poder do emir árabe vencedor dos cristãos, é salva in extremis pelo heróico Cavaleiro Negro que era, nem mais nem menos, o próprio Eurico. Naquele fim de mundo, nada nem ninguém poderiam impedir que Eurico casasse com Hermengarda. Contudo, o celibato eclesiástico de Eurico inibia-o de fazê-lo, daí a loucura de Hermengarda e o combate suicida em que Eurico voluntariamente entra. (BEIRANTE; CUSTÓDIO, 1977, p.6)
\end{abstract}

Conforme afirmamos, o trecho acima descreve a trama de Eurico, privilegiando principalmente o ponto de vista amoroso aí contido, mas há ainda um contexto histórico bastante importante, que retrata a invasão da Península Ibérica pelos muçulmanos vindos da África, no início do VIII século e a consequente queda do império gótico. José-Augusto França destaca nesse âmbito "um fundo de acontecimentos, cortado por batalhas, alianças, traições, vinganças bárbaras [...]" (FRANÇA, 1993, p.133).

De fato, a ação narrativa inclui todos esses elementos ao retratar a disputa territorial entre árabes e godos. No início da trama, Eurico surpreende uma conversa “[...] entre o chefe árabe Táriq e um conde cristão traidor [Juliano] que tinha o governo de Septum. [...] consumava-se aí a traição dos que abriam as portas do Estreito aos inimigos das Espanhas.” (NEMÉSIO, 1979, p.IX). As palavras de Vitorino Nemésio, que mimetizam o tom narrativo da obra herculaniana, ressaltam ainda, nessa mesma cena, a presença do bispo católico Opas que, traiçoeiramente, também, estaria no 
comando dos árabes de Híspalis. Eurico, então, escreve a Teodemiro, seu antigo irmão de armas, e atual Duque de Córdoba, contando o ocorrido e alertando para a fragilidade do reinado de Roderico: "Que Teodemiro velasse, Roderico é rei fraco;” (NEMÉSIO, 1979, p.IX).

Conforme esperado, consuma-se, assim, a batalha entre godos e mouros, mas ao lado desses participavam, também, alguns cristãos traidores: Sisebuto, Ebas, Juliano e Opas. Apesar da corajosa e heróica participação do Cavaleiro Negro, que na verdade seria o próprio Eurico, os visigodos são vencidos: "Em vão o Cavaleiro Negro surge como um corisco: só terá tempo de abrir uma grande clareira nas linhas, increpar Roderico, vê-lo morrer, perder-se de Teodemiro e atirar-se à linfa de Chryssus." [NEMÉSIO, 1979, p.X]. E, com a morte de Roderico, Teodemiro é eleito seu sucessor.

Posteriormente a esses fatos que desencadearam a queda da monarquia visigótica na Espanha, ocorre o rapto de Hermengarda pelos árabes e sua dramática e surpreendente salvação por Eurico, conforme descrito acima. Os dois refugiam-se, juntamente com os outros godos participantes da ação, na caverna de Pelágio, irmão de Hermengarda e duque de Cantábria. Depois de revelado o segredo do sacerdócio de Eurico, o gardingo vai novamente ao encontro dos árabes.

Nesse momento, já ao final da narrativa, é apontado o início da reação cristã contra os muçulmanos: "A ventura das armas muçulmanas tinha chegado ao apogeu, e a sua declinação começava, finalmente. E na verdade, a ira celeste contra os godos parecia estar satisfeita." (HERCULANO, 1996, p.138). Tem início, então, a batalha de Cangas e Onis, protagonizada por Pelágio e o grupo de godos que junto com ele constituíram a resistência cristã nas Astúrias. O narrador ressalta, abaixo, a importância dessa batalha como ponto inicial para a reconquista cristã da península: 
Os que têm lido a história daquela época sabem que a batalha de Cangas de Onis foi o primeiro elo dessa cadeia de combates que, prolongando-se através de quase oito séculos, fez recuar o Alcorão para as praias da África e restituir ao evangelho esta boa terra de Espanha, terra mais que nenhuma de mártires. (HERCULANO, 1996, p.138)

Narra-se finalmente a morte de Eurico. Afastando-se do campo de batalha com os dois traidores da causa cristã, Juliano e Opas, e também com mouro Muguite, Amir da cavalaria árabe, o presbítero revela sua identidade e inicia-se um confronto entre eles, conforme descrito a seguir: "Um contra três! - Era um combate calado e temeroso. O cavaleiro da cruz parecia desprezar Muguite: os seus golpes retiniam só nas armaduras dos dois godos. Primeiro o velho Opas, depois Juliano caíram." (HERCULANO, 1996, p.140). A seguir Eurico se desfaz das próprias armas permitindo ser morto por Muguite:

Muguite, cego de cólera, vibrara a espada: o crânio do seu adversário rangeu, e um jorro de sangue salpicou as faces do sarraceno. Como tomba o abeto solitário da encosta ao passar o furacão, assim o guerreiro misterioso do Críssus caía para não mais se erguer!... (HERCULANO, 1996, p.140)

É interessante como as duas perspectivas, a amorosa e a histórica, ou bélica, tão distintas, descrevem de forma coerente o enredo da obra, mas é exatamente da interseção entre os dois eixos que se pode melhor compreender a pertinência de Eurico ao modelo tipicamente romântico de junção entre indivíduo e nação, conforme assinala abaixo, Ofélia Paiva Monteiro, sobre esse período:

Com nova acuidade se atenta, com efeito, na inter-relação indivíduo/meio, que pressupõe a de indivíduo/nação, e, tanto no plano individual como no plano nacional, luta-se pela conquista da identidade, entendendo-se que o indivíduo só a atingirá no contexto da sua nação e que esta só a alcançará, por sua vez, com indivíduos a quem der condições de realização pessoal [...]. (MONTEIRO in CASTRO, 2003, p.21) 
É também Ofélia Monteiro quem, em outro artigo referente à obra herculaniana, chama a atenção para um conto que teria dado origem à trama de Eurico: “Destruição de Áuria”. Também aí, a pesquisadora destaca o paralelismo entre o protagonista e a nação, atentando ainda para outras similaridades determinantes da consistente relação entre as duas obras. No seguinte tópico, abordaremos algumas questões referentes à temática desse conto, cotejando-o com o enredo de Eurico, no que se refere à figuração do mouro e outras questões tangentes a essa. Posteriormente, então, partindo dos subsídios extraídos desse confronto, prosseguiremos a análise relativa à narrativa de Eurico enfatizando o conflito entre cristãos e muçulmanos.

\section{II.3.3 - "Destruição de Áuria" e os antecedentes de Eurico}

"Destruição de Áuria" é um conto pouco conhecido de Alexandre Herculano, que foi publicado em 1838, no periódico $O$ Panorama, sem a assinatura do autor. Apenas em volume mais recente das obras completas de Herculano, organizado por Vitorino Nemésio, em 1970, o texto foi compilado, juntamente com outras narrativas inéditas, também extraídas d'O Panorama. Ofélia Paiva Monteiro, inclusive, com finalidade de comprovar a autoria do conto, elabora um artigo comparando-o a Eurico, o presbítero e definindo, de fato, a semelhança estilística e temática entre as duas narrativas. E é, justamente, o confronto entre mouros e godos, o que primeiramente chama a atenção da pesquisadora, em sua argumentação referente à similaridade entre as obras, como se pode verificar, a seguir: 
O tinir das armas godas e árabes acompanha, como no romance [Eurico], todo o entrecho da novela, insuflando-lhe um ar épico, avolumado de desgraça. Efetivamente, o rasto dos Muçulmanos é o da ruína e do sangue [...] (MONTEIRO, 1973, p.7).

As comparações entre o conto e Eurico são, mesmo, inevitáveis e vão bem além do período histórico retratado. Também Vitorino Nemésio elabora o seguinte parecer sobre as narrativas, destacando a própria forma como são constituídos os personagens e as ações. Nemésio enfatiza, ainda, a diferenciação entre a autoria experiente de Eurico e a prática literária incipiente, observada em "Destruição de Áuria":

\footnotetext{
"Destruição de Áuria" é um impressivo quadro da queda da Espanha visigótica, tocado da mesma mão que, aqui tateando, no Eurico modula a larga orquestração da passagem do Sália, as proezas sem par do Cavaleiro Negro. As astúcias varonis da heroína, doseando cruelmente as reações de gentileza à cegueira amorosa do infiel para salvar o seu príncipe, afinam pelo melhor tom do patético absoluto em romantismo [...] (NEMÉSIO, 1974, p.XVIII)
}

Ambientada, também, no VIII século, a narrativa de "Destruição de Áuria" retrata a tomada da cidade, denominada Áuria, pelos mouros, e o desafortunado destino amoroso de Afonso e Elfrida. Verifica-se que tanto o contexto amoroso quanto o histórico, contemplados na narrativa, confluem com os motivos abordados em Eurico, parecendo-nos, de fato, bastante profícuo o cotejamento das duas narrativas. Diferentemente de Eurico, contudo, a trama de "Destruição de Áuria" é bastante simples e pouco pródiga na constituição de personagens e na complexidade temática.

Como dissemos, o conto contempla, inicialmente, a tomada de Áuria, localizada na região da Galiza, pelos mouros, apresentando-se, posteriormente, o par amoroso, Elfrida e Afonso. Há, entretanto, uma evidente desproporção entre a questão bélica retratada no início do texto e as ações da heroína, capturada pelos mouros, que 
vem a ocupar, depois, uma grande parte da narrativa. A tomada de Áuria e sua destruição ocupam apenas o contexto inicial, e a partir de determinado momento acompanham-se somente os fatos relativos ao cativeiro de Elfrida e as suas ações para tentar se libertar. Estranhamente, nem mesmo ao final da trama, apresenta-se uma amarração adequada ao contexto inicial da narrativa. Ocorre aí, unicamente, uma breve referência ao destino de Afonso e da cidade de Áuria:

Ai! Ela não sabia que Afonso era vivo; nem ele os atos heróicos do inextinguível amor de Elfrida. Os plainos de Áuria não tinham sido para Afonso o leito de morte. Exaurido de forças, caíra entre o montão de mortos e moribundos; mas enfim despertou do seu desmaio e pôde salvar-se. Brevemente souberam os Mouros, à própria custa, que ainda vivia! Mas onde estava ele nesta noite medonha, em que Elfrida fugia sozinha do campo de infiéis? (HERCULANO, 1973, p.29)

Após esse comentário volta-se, novamente, para a ação de Elfrida, e, em uma quebra com o tom mais realista, mantido até então na narrativa, descreve-se, com contornos fantásticos, a sua alienação, desvario e, finalmente, morte. O conto é finalizado com o seguinte excerto, no qual sugere-se, até mesmo, a transformação da protagonista em uma "alma errante".:

E ainda agora, muitas vezes, ao anoitecer, segundo dizem os crédulos camponeses, a alma errante de Elfrida anda pelas planícies de Áuria. Também os velhos contam haverem visto o seu espectro nas noites de alguns invernos, que já lá vão há muito, e que as mesmas criancinhas se arrepiavam, ao ouvir nas horas da modorra ou seus altos clamores de aflição. Agouro de mau fado é o escutar os sons inarticulados das almas errantes: assim, quando ressoa a voz noturna da dona de Áuria, todas as raparigas do vale rezam e fazem promessas aos santos da sua maior devoção. (HERCULANO, 1973, p.30)

No que se refere, especificamente, ao combate entre godos e mouros, conforme já colocado, há uma concentração em torno do assunto, apenas, na primeira metade da narrativa. A relação conflituosa entre os povos é apresentada em uma 
estruturação dicotômica, na qual são enfatizados os valores heróicos dos godos em oposição às desonras e vilezas destacadas no comportamento dos mouros. Assim, a corajosa resistência dos godos, na defesa das terras da Espanha, em sua luta contra os chamados infiéis, é comumente ressaltada no texto, conforme, também, exemplificado na citação disposta abaixo:

[...] o império godo não baqueou com ignomínia: não herdaram os filhos da Espanha nenhuma herança de opróbrio. [...] Os exércitos godos não fugiram; foram passados à espada e totalmente aniquilados; mas deixando repassadas de sangue mourisco as veigas do meio-dia [...] (HERCULANO, 1973, p.24)

E, se como dissemos, os mouros são retratados como antagonistas cruéis, sem escrúpulos e valores morais, a religião muçulmana é apontada como principal responsável por tais atitudes, como se pode verificar, por exemplo, no seguinte fragmento: "O árabe fero e o incansável sarraceno se haviam ligado com os desumanos filhos da África. A mesma crença os tinha fraternizado; o mesmo espírito de uma religião feroz, e de uma ambição desvairada, os havia tornado conquistadores." (HERCULANO, 1973, p.23).

A diferença religiosa parece, de fato, constituir um fator historicamente determinante da inimizade entre godos e mouros, sendo a disputa entre eles muitas vezes entendida, antes de tudo, como um conflito de cunho religioso. Ana Rita Gaspar Moreira diz que, diversamente da dificuldade em se determinar a identidade dos povos peninsulares, “[...] a identificação dos invasores mouros é [...] relativamente inequívoca" (MOREIRA, 2005, p.77). E a pesquisadora destaca, justamente, a diferença religiosa como fator definitivo para explicar a aversão suscitada por esses povos, conforme exposto em sua argumentação, disposta a seguir: 
Os invasores são globalmente identificados como povos de raça e religião diferente. A estas "mútuas repugnâncias" acresce, após a conquista, a que é, segundo Herculano, usualmente provocada pela "sujeição de povos conquistados". Entre estas múltiplas aversões, realmente, a mais referida - e aquela à qual é concedida maior relevância - é a diferença religiosa. Alberto Sampaio identifica os povos invasores como "inimigos de raça, de costumes e sobretudo de religião, diferentes." Similarmente, Pinheiro Chagas elege, entre outros motivos, a "inimizade religiosa" como o conflito essencial que subsiste "à convivência e à assimilação social"[...] (MOREIRA, 2005, p.77)

Desse modo, percebemos que, em ressonância com a perspectiva de autores oitocentistas, o conto de Herculano, apresenta uma oposição bastante incisiva entre os invasores mouros e os godos, habitantes da Espanha, enfatizando, principalmente, a aversão religiosa entre cristãos e muçulmanos, também destacada pelos historiadores portugueses do XIX.

A seguir, aproveitando, algumas questões aqui colocadas, referentes à representação dos mouros e godos no conto "Destruição de Áuria", retomaremos a análise de Eurico, considerando, também, mais especificamente, a figuração desses povos na constituição narrativa. Se Vitorino Nemésio e Ofélia Paiva Monteiro percebem naquele conto uma matriz inicial a partir da qual poderia ter sido desenvolvida a história do presbítero ${ }^{5}$, veremos, entretanto, no seguinte tópico, que o romance contempla deslocamentos na forma de abordagem tanto dos mouros quanto dos godos.

\footnotetext{
5 “[...] todos os vocábulos expressivos de "Destruição de Áuria" como todas as imagens e metáforas, são frequentes em Herculano, particularmente no Eurico; [...] as notas [...] mostrarão quanto, naquele romance, se encontram passos que são meros desenvolvimentos de expressões contidas na "Destruição de Áuria”, ou de lances e atitudes aí romanescamente já criados.” (MONTEIRO, 1973, p.21)
} 


\section{II.3.4 - Figurações de mouros e godos em Eurico, o presbítero}

Conforme exposto anteriormente, alternando-se entre o paralelismo e a convergência, o mote da impossibilidade de realização amorosa entre Eurico e Hermengarda é acompanhado pelo contexto da disputa territorial entre cristãos e muçulmanos. A relação entre os dois povos é apresentada, inicialmente, de forma polarizada. Enquanto os muçulmanos são, de fato, contemplados como invasores, os visigodos que, há bastante tempo, haviam se instalado na Espanha, são apresentados como os antigos e legítimos conquistadores da Península. Conforme informa o narrador, a ocupação germânica e, especialmente, a tribo visigótica encontra-se, no momento, completamente integrada aos romanos que antes dominavam o espaço ibérico:

Desde essa época, a distinção das duas raças, a conquistadora ou goda e a romana ou conquistada, quase desaparecera, e os homens do norte haviam-se confundido juridicamente com os do meio-dia em uma só nação, para cuja grandeza contribuíra aquela com as virtudes ásperas da Germânia, esta com as tradições da cultura e polícia romanas. (HERCULANO, p.13 - 14, 1996)

Importa enfatizar ainda, o fato informado no início do relato, de que os godos haviam aí se fixado e adotado a religião cristã, há mais de um século. Pode notarse então que, embora fossem, anteriormente, invasores da península, eles são agora designados como os detentores dos valores associados à nacionalidade e ao cristianismo. Da pesquisa de Ana Rita Gaspar Moreira referente à própria historiografia de Alexandre Herculano é possível depreender uma perspectiva que poderia respaldar tais fatos apresentados na narrativa de Eurico: 
As invasões bárbaras provocariam uma nova cisão, mas a linha que dividira por largo tempo a população hispano-romana submetida e os visigodos conquistadores fora, com o tempo, diluída. Romanos e Godos partilhavam agora um direito único, instituições e crenças comuns. Comparada com a comunicação entre as sociedades cristã e muçulmana, a "incorporação" romano-goda teria sido mais "completa", pela ausência de reação dos vencidos, pela identidade de crença, e porque os godos estavam já parcialmente romanizados (MOREIRA, 2005, p.64).

Mas, a consagração dos godos, também em um âmbito mais geral, se faz tão evidente que, Friedrich Nietzsche, na Genealogia da moral, define, através de uma breve pesquisa histórica e etimológica, a associação entre o conceito de "bom" e uma linhagem considerada divina, guerreira e aristocrática: os godos. Assim, para se revisar a atual oposição, entre as concepções de "bom" e "mau", o filólogo retoma a nobreza e aristocracia de tempos remotos para localizar, nesse contexto, a gênese do termo "bom" associada ao "espiritualmente bem nascido, espiritualmente privilegiado" em oposição ao "ruim" que seria o plebeu (NIETZSCHE, 2005, p.21). Nietzsche recupera a própria etimologia da palavra "bom", tomando bonus do latim como o guerreiro, gut do alemão como homem de linhagem divina e, ainda, goten como referência aos godos: o "alemão Gut [bom]: não significaria 'o divino' [göttlichen Geschlechts]? E não seria idêntico ao nome do povo (originalmente da nobreza), os godos [Goten]?” (NIETZSCHE, 2005, p.23).

Dessa forma, em um contexto mais abrangente, nota-se que, a presença dos godos na constituição de algumas nações européias é tão significativamente vinculada aos signos de heroicidade e nobreza que até mesmo Nietzsche, para fundamentar teses de cunho filosófico, encontra na nobreza gótica um parâmetro importante. Verifica-se assim, de fato, o lugar privilegiado ocupado por esses povos no âmbito histórico, mas, principalmente, no imaginário coletivo europeu, como destaca, também, o próprio autor 
de Eurico que, na introdução à obra, atenta para "[...] majestade escultural que conserva sempre a raça visigótica [...]" (HERCULANO, 1996, p.11).

Retomando, também, a representação do elemento romano na narrativa de Eurico, encontramos uma caracterização corrupta e decadente atribuída a esses povos. E, mesmo que os habitantes da península sejam designados, de maneira geral, apenas por godos, destaca-se a prevalência de caracteres romanos, como fator determinante da decadência moral entre eles. Assim, os godos, cuja origem bárbara é exaltada pelo narrador, como "as virtudes ásperas da Germânia" (HERCULANO, 1996, p.14) apresentam-se contaminados pelos costumes imorais e corruptos dos romanos decadentes, aos quais subjugaram, como se pode acompanhar, no seguinte excerto extraído da narrativa de Eurico:

A civilização [romana], porém, que suavizou a rudeza dos bárbaros era uma civilização velha e corrupta. Por alguns bens que produziu para aqueles homens primitivos, trouxe-lhes o pior dos males, a perversão moral. A monarquia visigótica procurou imitar o luxo do império que morrera e que ela substituíra. Toletum quis ser a imagem de Roma ou de Constantinopla. (HERCULANO, 1996, p.14)

Apreende-se deste fragmento e de considerações anteriormente feitas à obra, não apenas, a responsabilização dos romanos pela falibilidade moral identificada nos godos, como, aparentemente, também, a minimização da importância do cristianismo, conforme também veremos adiante. Relembrando, ainda, a forma sempre elogiosa como os godos são retratados, em "Destruição de Áuria", fica mais evidente a caracterização decadente desses elementos em Eurico. Assim, diversamente de uma perspectiva generalizante, acatada inclusive por Nietzsche, e pelo próprio Herculano em tal conto, na qual são identificados, nas tribos visigóticas, signos de vitalidade, coragem e heroísmo, extraídos exatamente de sua caracterização bárbara, em Eurico, acompanha- 
se a representação da decadência goda associada à herança civilizatória romana.

Mas, se em diversos autores, a decadência é entendida como o esgotamento de determinada civilização, em outros, como Friedrich Nietzsche, há uma associação imediata entre o vetor civilizacional e os signos de decadência. E, prosseguindo aquela linha de raciocínio desenvolvida pelo filósofo e filólogo alemão, na qual o conceito moral de "bom" teria sido extraído da mesma etimologia de "godo", destaca-se, entretanto, em um dado contexto histórico, uma inversão das polaridades anteriormente estabelecidas. Seria, então, constituída a oposição entre o "bom", pobre e débil, e o "mau", forte e poderoso, com evidente privilégio moral do bom sobre o mau, em substituição àquela conformação anterior que associava o "bom" ao nobre, em oposição ao ruim, que seria o simples ou fraco. A partir de então, o cristianismo torna-se a principal referência para a discussão nietzscheana sobre a questão moral. Para o filólogo alemão, o cristianismo corresponderia à completa apatia e alienação da vontade, favorecendo, assim, a formação do homem domesticado, sem vontade própria, educado apenas para obedecer. Os instintos naturais, definidores da própria natureza humana, seriam condenados em nome de um ascetismo artificial, gerando, inclusive, a desnaturalização do homem.

Embora um pouco posterior a Herculano e atuando em um âmbito bastante diverso, a evocação de Nietzsche nos interessa aqui por tornar mais profícuas algumas questões vagamente apresentadas na narrativa de Eurico, o presbítero. Assim, temos, a princípio, como intersecção entre a perspectiva apresentada nessa obra literária e os argumentos nietzscheanos aqui destacados, o elogio do bárbaro em detrimento do civilizado, que, em ambos os casos, seria análogo ao decadente.

De fato, como vimos acima, o termo "bárbaro" para Nietzsche corresponde 
ao que não é domesticado e, portanto, decadente, ao ser da vontade e dos instintos. E o elogio do "bárbaro", em Eurico, se alinha também a essa perspectiva da não domesticidade, da prevalência do instinto em detrimento da razão, chegando ao elogio do selvagem. Mas, se a civilização romana é apresentada como decadente, e parte dos godos parece, nesse momento, também corrompida, a narrativa evidencia em outros elementos, alheios à decadência civilizacional e, aparentemente também, ao cristianismo, o vigor e vitalidade de um grupo que, na barbárie de seus costumes e isolamento, se manteve imune aos males da civilização:

Os montanheses do Hermínio na Lusitânia, aborígenes, talvez, daquele país, os quais, na época das invasões germânicas, bem como já na da conquista romana, a custo haviam submetido o colo ao jugo de estranhos, e os vascônios, habitadores selvagens das cordilheiras dos Pirineus, constituíam com os servos um grosso de gente a que hoje chamaríamos a infantaria do exército. [...]. Requeimados pelo sol ardente do estio ou pelo vento gelado dos invernos rigorosos das serranias, incapazes de reconhecer a ordem e a disciplina, estes homens rudes combatiam meio nus e desprezavam todas as precauções de guerra. $\mathrm{O}$ seu grito de acometer era um rugido de tigre. Vencidos, nunca lhes ouvia pedir compaixão; porque, vencedores, não havia a esperar deles misericórdia. (HERCULANO, 1996, p.54)

Há, realmente, afinidades contundentes entre o elogio do bárbaro em

Alexandre Herculano, ou mais propriamente em Eurico, o presbítero, e a concepção nietzscheana de uma barbárie vitalizante, anterior à decadência civilizacional, histórica e mataforicamente apontada, na Genealogia da moral, na constituição do

[...] animal de rapina, a magnífica besta loura que vagueia ávida de espólios e vitórias; de quando em quando este cerne oculto necessita desafogo, o animal tem que sair fora, tem que voltar à selva [...] (NIETZSCHE, 2005, p.32).

A questão religiosa, entretanto, parece acomodar-se mal à intersecção aqui destacada entre algumas concepções do filósofo alemão e a narrativa herculaniana. Pois, 
se Friedrich Nietzsche aponta, claramente, no cristianismo uma das principais causas da decadência moral, a narrativa de Eurico, entretanto, é permeada de referências elogiosas e apologéticas a essa religião. Mas, se tal diferença parece constituir uma cisão entre as duas perspectivas, sob a luz da argumentação nietzscheana, entretanto, poderíamos entrever a possibilidade de revisar os contornos da representação do cristianismo na obra mais celebrada de Alexandre Herculano.

Importa, também, recordar que na narrativa de $O$ Bobo, por exemplo, ocorre, em diversos níveis, a dessacralização da origem da nação portuguesa. Mas, especialmente, na figuração de Martim Eicha, o mouro convertido ao cristianismo, para o qual a religião não acrescentou nenhum benefício moral, pode-se identificar uma perspectiva que minimizaria o alcance benéfico dessa religião. Assim, tomando também esse precedente, faz-se necessário questionar se as concepções tão afinadas, referentes à decadência civilizacional em Friedrich Nietzsche e Alexandre Herculano, seriam, mesmo, absolutamente divergentes no que concerne ao cristianismo na narrativa de Eurico, o presbítero.

Há pelo menos alguns indícios que viabilizam a aproximação entre o cristianismo e a decadência em Eurico. Conforme explicitado na narrativa, a corrupção incidida entre os godos atingira também o próprio clero (HERCULANO, 1996, p.14). E, um dos principais elementos responsáveis pela traição ao império visigótico é o bispo Opas, que, passando para o lado dos árabes, constitui uma das principais figuras do exército muçulmano. Ao final da narrativa, inclusive, quando Eurico participa do embate, já descrito acima, contra o bispo Opas, Juliano, o conde cristão governante de Septum, e o mouro Muguite, os seus alvos mortais são, de fato, os dois cristãos traidores. E é pelas mãos de um mouro que o presbítero se deixa vencer, entregando-se 
à morte.

Mas, especificamente, no protagonista, Eurico, encontrar-se-ia, de fato, o paradigma do herói cristão incorruptível. Conforme declara Capelo Pereira sobre o personagem, configura-se, realmente, no presbítero de Cartéia um “[...] ser de exceção, profeta inspirado movido pelo culto do amor da pátria [...] profundamente crítico da sociedade degenerada de que se afasta, privilegiando a solidão e o ermo [...]" (PEREIRA, 1997, p.226). E, ainda que seja godo, tendo, portanto, uma origem "bárbara", os atributos destacados nesse personagem têm, de modo geral, o cariz civilizatório, como também o afirma Vitorino Nemésio:

Se Eurico é melancólico e desesperado [...] não é selvagem, senão tiufado, gardingo e padre - três vezes civilizado. [...] se Eurico foge ao convívio dos homens, [...] não aspira a um regresso à natureza. Não é rousseauniano; a exaltação do seu eu é religiosa e moral. (NEMÉSIO, 1979, p.XXV).

No entanto, aquele que consegue, assim, conjugar positivamente civilização, moral e cristianismo, é justamente, também, o personagem cujo destino individual apresenta maior falibilidade. Acontece que a narrativa de Eurico, do mesmo modo que a de $O$ Monge de Cister, teria, a princípio, o propósito de questionar o celibato clerical. E se, conforme argumenta José-Augusto França, a centralidade da "vida solitária do monge" acaba sendo uma questão secundária (FRANÇA, 1993, p.132) da trama, a equivocada opção sacerdotal de Eurico é patente. Assim, se não diretamente o cristianismo, mas a sua função religiosa e a moralidade aí imposta, cuja principal consequência é o impedimento da realização amorosa, constituem as questões determinantes para que o herói presbítero cumpra o destino fatal.

França traduz bem o que consideramos ser a falência do protagonista, apresentada já no início da narrativa: “[...] as meditações de um sacerdote infeliz 
torturado pelo desespero, a raiva e o ciúme no seu eremitério à beira mar, e o encontro impossível com uma mulher, perdida dez anos atrás.” (FRANÇA, 1993, p.132). Dessa forma, como subterfúgio para infelicidade amorosa, Eurico abraça radicalmente o cristianismo, tornando-se monge e, ironicamente, por isso mesmo, fica impedido, posteriormente, de casar-se com Hermengarda. Ao fim dessa sequência de eventos desafortunados, evidencia-se o colapso do herói: ele entrega-se ao inimigo, sem nenhuma resistência, para ser morto.

Desse modo, parece claro que o conflito geral apresentado na narrativa, entre o cristianismo e o islamismo, implicaria outras relações nem sempre dicotômicas. E, se na polaridade referente aos godos, apresenta-se uma confluência entre cristianismo, civilização, decadência e barbárie, no contexto relativo aos mouros as condições são também ambíguas, como veremos a seguir.

O que se coloca, primeiramente, de forma inequívoca, na narrativa, é a caracterização depreciativa dos muçulmanos. Na voz do heróico protagonista, por exemplo, acompanha-se, conforme exposto a seguir, a condenação contundente dos árabes:

Os árabes! - eis o único grito que o interrompe; e esta palavra é maldita é como a peste quando passa: seguem-na o susto e o desacordo. A vileza do coração humano surge após ela em toda a hediondez do seu aspecto. O terror acabou com os mais santos afetos e, até, com o amor filial e paterno. Cada qual busca salvar-se a si próprio. Os netos dos nobres godos converteram-se em um bando desprezível de covardes e egoístas. (HERCULANO, 1996, p.39).

Observa-se que, além da caracterização negativa dos mouros, a citação apresenta também uma nova relação de causalidade entre a invasão árabe e a decadência goda. A infâmia dos godos é aqui, se não justificada, pelo menos extraída, justamente, da presença dos mouros na Península. O deslocamento contido nessa perspectiva talvez 
possa ser explicado pelo fato de ser Eurico quem a apresenta, não sendo necessariamente representativa da concepção geral contida na narrativa, no que se refere à relação entre a presença dos árabes e a corrupção dos godos. Como vimos, a voz narrativa atribui tal condição à decadência moral dos romanos que teria contaminado os godos, depois de um período de convivência entre os povos.

Mas, também, pela voz de outra personagem bastante fidedigna, Hermengarda, constitui-se uma argumentação referente à imoralidade dos árabes, que poderia ser paradigmática da perspectiva geral apresentada na narrativa: “[...] a infâmia tem sido escrita por eles na fronte das famílias mais ilustres da Espanha: o cutelo ou a prostituição é o que os árabes oferecem à inocência." (HERCULANO, 1996, p.79). Tais dizeres fazem parte de um diálogo entre Hermengarda e Cremilde, em um dos episódios mais comentados de Eurico, referente à invasão do Mosteiro da Virgem Dolorosa pelos árabes, que intentavam levar as freiras para os seus haréns.

Cremilde, a abadessa do Mosteiro, sacrifica, então, cada uma das freiras, que preferem tal destino em detrimento da vida que levariam como escravas dos muçulmanos. Em nota, o próprio autor faz um comentário sobre a veracidade dos fatos aí descritos. Observa-se, pela seguinte expressão utilizada, “[...] sensualidade brutal dos árabes" (HERCULANO, 1996, p.81), que também ele parece compartilhar de certa expectativa caricatural em relação aos muçulmanos:

O fato narrado neste capítulo é histórico. O lugar da cena e a época é que são inventados. Foram as monjas de Nossa Senhora do Vale, junto de Ecija, que em tempos posteriores, praticaram este feito heróico, para se esquivarem à sensualidade brutal dos árabes. (HERCULANO, 1996, p.81).

De fato, em uma apreciação geral da obra, o que se destaca de forma bastante evidente é a caracterização negativa dos árabes, suas atitudes imorais, 
relacionadas com a permissividade atribuída ao próprio islamismo. Mas, para além dessa perspectiva mais óbvia, referente à condenação geral dos mouros, que, realmente, perpassa quase toda a narrativa, ocorrem também oscilações na representação desses povos, relativizando, a nosso ver, o seu antagonismo. Um dos atenuantes da figuração antagônica dos árabes pode ser verificado, exatamente, nas descrições de algumas batalhas, nas quais apresenta-se uma equivalência entre o exército muçulmano e o cristão, sobressaindo-se, eventualmente, apenas, a heroicidade de Eurico. Parece prevalecer, nesses casos, uma proporcionalidade entre o número de guerreiros godos e mouros, observando-se até mesmo naquilo que a guerra teria de mais violento e arrasador uma equivalência entre os dois exércitos:

Cada cavaleiro árabe travou-se com um cavaleiro godo, e os dois contendores esquecem-se de tudo quanto os rodeia [...]. Firmes, os guerreiros cristãos vibram a pesada acha de armas que tomaram dos francos [...]. Estes [os árabes] [...] volteiam em roda dos adversários, e, quase ao mesmo tempo, os acometem por um e outro lado, tão rápido é o seu perpassar. Nesta luta de força e destreza, ora o duro neto dos visigodos, deslumbrado pelo incessante dos golpes, esvaído pelas muitas feridas, sufocado pelo peso da armadura, vacila e cai como pinheiro gigante; ora o ligeiro Agareno vê coriscar em alto o franquisque e logo o sente, se ainda sente, embargar-lhe o ultimo grito na garganta [...]. Assim, os centros dos dois exércitos semelham o tigre e o leão no circo, abraçados, despedaçando-se, estorcendo-se enovelados, sem que seja possível prever o desfecho da luta [...] (HERCULANO, 1996, p.56)

A narrativa aponta, ainda, um paralelismo entre os africanos participantes do exército muçulmano e os lusitanos do lado cristão. Aos “[...] montanheses do Hermínio na Lusitânia, aborígenes, talvez [...], [que] desprezavam todas as precauções da guerra [...]” (HERCULANO, 1996, p.54), conforme já foi citado acima, são contrapostos os africanos que lutavam junto com os árabes do lado muçulmano: 
Os esquadrões árabes eram a flor do exército de Tárique; mas a catadura selvagem dos africanos seus aliados, neófitos do islamismo, produzia, porventura, mais temor do que o aspecto deles. Torvos e ferozes eram o gesto e os meneios destes homens sem disciplina, cujas paixões se lhes pintavam nos rostos tostados e rugosos, nos olhos banhados de fel e orlados de sangue, e de cuja bruteza e miséria davam testemunho os manguais que lhes serviam de armas (armas terríveis, com que abolavam os elmos mais reforçados) e a hediondez dos seus albornozes pardos [...] (HERCULANO, 1996, p.53)

Comentando, exatamente, este contexto de Eurico, o presbítero, no qual é retratado o confronto entre mouros e iberos na Batalha de Guadalete, Ana Rita Gaspar Moreira faz a seguinte colocação:

Para além da distribuição de povos distintos pelas fileiras da batalha, Herculano faz aqui realçar a hierarquia civilizacional que se sobrepõe à luta principal e une os dois lados do combate. Em contraste com a superioridade material e moral dos chefes militares, a soldadesca é, em ambos os exércitos, "bárbara" e "selvagem". (MOREIRA, 2005, p.65).

Nesse caso, a diferença étnica parece ser suplantada pela ênfase em um tipo de estratificação social próprio dos campos de batalha. Desloca-se, assim, a divergência primordial entre cristãos e muçulmanos, para outro tipo de segmentação praticada de forma equivalente entre os dois exércitos, constituindo-se afinal um paralelismo entre eles. Já no seguinte excerto, referente à mesma obra de Alexandre Herculano, Ana Rita Moreira destaca, de fato, o enfoque relativo ao confronto constituído pela divergência entre europeus e islâmicos:

Mas na primeira batalha entre peninsulares e invasores é a "muralha de ferro [...] entre o Islamismo e a Europa" que identifica a fronteira identitária, ainda que se confunda - ou sobretudo porque se confundem -, na intensidade e na natureza, os respectivos gritos de guerra. (MOREIRA, 2005, p.65)

Conforme sugerido por Gaspar Moreira, pode-se, realmente, identificar, na 
narrativa de Eurico, perspectivas distintas de se retratar o conflito entre mouros e iberos, ora desconsiderando a questão da etnia em favor de elementos extrínsecos, aparentemente mais significativos, ora tomando, de fato, a diferença, entre europeus e muçulmanos, como condição antagônica absoluta. Mas, em ambos os casos, permanece, no mínimo, uma equivalência bélica entre os dois exércitos.

Outro aspecto do conflito, no qual, surpreendentemente, é possível também verificar um paralelismo entre os opositores, pode ser identificado na própria motivação religiosa tomada como causa e finalidade imperativa para as ações tanto dos mouros quanto dos godos. Enquanto os godos dizem, "Cristo e avante" (HERCULANO, 1996, p.55), Tárique anuncia: “Allah hu Acbar", "Deus só é grande” (HERCULANO, 1996, p.55), conforme tradução do próprio autor. De fato, o chefe árabe, Tárik, em conversa com o traidor godo, Juliano, defende com argumentos religiosos a tomada da Península, como exposto nas seguintes citações, extraídas de tal diálogo: "Vi em sonhos o profeta de Deus, que me disse: - 'a Espanha curvar-se-á ao Alcorão' - e Maomé não mente!’ (HERCULANO, 1996, p.41). E, um pouco adiante, o líder mouro prossegue sua argumentação, da seguinte forma: "Bem sei que não podes compreender o que é a fé viva de um muçulmano na proteção de Deus: mas seria eu réu do inferno, se duvidasse um instante das promessas do Profeta." (HERCULANO, 1996, p.41).

Assim, da mesma forma que, ao longo de toda a narrativa, apresenta-se a defesa do cristianismo pelos iberos, também, na argumentação do chefe muçulmano, Tárik, encontra-se uma proposição consistente que endossa o islamismo. Há, portanto, uma justificativa religiosa, coerentemente elaborada, constitutiva de uma motivação imperativa, que poderia, mesmo, sob determinada perspectiva, validar as ações dos invasores mouros. 
Destacamos a relevância de tais circunstâncias na narrativa de Eurico, pois, a figuração negativa do bispo Opas e de outros religiosos católicos ou, mesmo, a falência do presbítero Eurico, estariam limitadas, em todo caso, ao âmbito anti-clerical, mas a viabilização do discurso legítimo e coerente de um muçulmano, defendendo a sua fé, abre a possibilidade do reconhecimento da religiosidade islâmica. Dessa forma, se o tom geral da narrativa contém o privilégio evidente da religião cristã, em algumas situações, pontuadas ao longo da obra, abre-se a possibilidade do questionamento e relativização de tal hegemonia religiosa. E, se cotejarmos, especificamente, o comportamento dos godos traidores com aquele apresentado pelos mouros, distinguiremos circunstâncias que indiciam, inclusive, a preeminência dos valores muçulmanos. Um exemplo incisivo de tal situação pode ser acompanhado quando o próprio xeque árabe, Abdulaziz, ao presenciar a cena de um banquete entre os cristãos, demonstra desprezo pelo comportamento dos godos traidores, participantes de seu exército, que seriam incapazes de compreender os preceitos do Alcorão:

Vede os nazarenos malditos - dizia Abdulaziz em voz baixa ao xeque Abdalá, olhando de através para os godos. - $\mathrm{O}$ amor da embriaguez nunca os deixará ver a luz que mana das páginas do divino Alcorão. Para eles o fruto da vida será sempre a ponte estreita, da qual, ao passarem na morte, se despenharão no inferno. (HERCULANO, 1996, p.94)

Abdulaziz apresenta, evidentemente, o ponto-de-vista comprometido com o islamismo, mas o seu discurso parece bastante genuíno, constituindo-se, inclusive, como prolongamento de uma perspectiva semelhante, apresentada pelo próprio narrador, que pouco antes fizera os seguintes comentários sobre a mesma cena: "Aqueles homens perdidos, rodeando esse montão de abominações, ainda embriagavam-se, bebendo pelos vasos sagrados, e escarneciam blasfemos a crença da 
sua infância no meio da hedionda hebriedade.” (HERCULANO, 1996, p.93)

Percebemos, assim, que o conflito geral apresentado na narrativa de Eurico, e amplamente divulgado pela crítica referente à obra, entre os valores heróicos dos cristãos e a imoralidade e vileza dos muçulmanos, abarca em seu interior outras nuances que desarticulam a caracterização dicotômica mais evidente. O cristianismo, claramente associado aos parâmetros civilizacionais, parece, também, habilmente relacionado aos signos de decadência. Por outro lado, alguns discursos pontuais, dissidentes do eixo principal da narrativa, promovem a legitimação da religiosidade e dos valores islâmicos. Mas, para além do plano geral referido e das pequenas, mas incisivas, rasuras que comprometem a sua integridade, há ainda uma conformação interessante que, embora pouco destacada, parece constituir o sentido mais abrangente de articulação entre cristãos e muçulmanos na narrativa de Eurico. Referimo-nos à idéia apresentada em alguns pontos do texto de que os árabes atuariam como instrumento divino para castigar a corrupção disseminada entre os godos, conforme sugere o seguinte fragmento, encontrado já no início da obra:

Contam-se coisas incríveis desses povos que assolam a África, chamados os árabes, e que, em nome de uma crença nova, pretendem apagar na terra os vestígios da cruz. Quem sabe se aos árabes foi confiado o castigo dessa nação corrupta. (HERCULANO, 1996, p.37)

O que, acima, é suposto ganha maior consistência ao longo da narrativa e, em determinado momento, aponta-se, de fato, o chefe muçulmano Tárique como um enviado divino, cuja missão seria aniquilar o poderio godo: "Tárique era o anjo exterminador mandado por Deus às Espanhas, e a sua espada o raio despedido do céu para fulminar o império dos godos." (HERCULANO, 1996, p.50). Nesse caso, a função antagônica parece ser deslocada dos muçulmanos para os godos decadentes, já que os 
primeiros, de alguma forma, cumprem os propósitos divinos para os quais foram designados.

Embora, nas expressões, de cunho figurativo, destacadas acima, não haja uma afirmação categórica de que a tomada da Espanha pelos muçulmanos tenha sido realizada devido à punição de cunho místico, em alguns trechos da obra fica evidente, no mínimo, que essas circunstâncias fariam parte de um plano divino: "Deus contara os dias do império de Leovigildo, e o sol do último deles era o que descia já para o ocidente!" (HERCULANO, 1996, p.63). E a idéia de punição divina, insinuada ao longo da narrativa, é reforçada em seu final, quando os árabes já dominaram, de fato, grande parte do território da Espanha, e anuncia-se um novo ponto de inflexão para a disputa: "A ventura das armas muçulmanas tinha chegado ao apogeu, e a sua declinação começava finalmente. E na verdade, a ira celeste contra os godos parecia dever estar satisfeita.” (HERCULANO, 1996, p.137)

Luís Alexandre Rodrigues Sobreira refletindo sobre o conjunto da obra romanesca de Herculano argumenta, de forma bastante lúcida e precisa, que o autor privilegia "os momentos de crise, em que se registra o fim de uma ordem antiga e a passagem a um novo estágio. As causas da transição são, na sua perspectiva, endógenas, não meramente conjunturais." (SOBREIRA, 1998, p.98). E, especificamente, com relação a Eurico, Rodrigues Sobreira ressalta que "é a podridão da sociedade visigótica que determina e possibilita a invasão árabe [...]" (SOBREIRA, 1998, p.98). De fato, não apenas a invasão, mas o sucesso do domínio muçulmano sobre a Espanha é justificado na narrativa de Eurico, principalmente, pela ajuda dos godos ao exército árabe.

Mas, a figuração do mouro como instrumento de um plano divino cristão para expurgar o império godo decadente não reforçaria também essa endogenia? A 
ênfase permaneceria, assim, no domínio cristão, a motivação inicial e a finalidade de tal projeto estariam voltadas para a assepsia da corrupção e decadência herdada dos romanos para, então, se renovar o cristianismo na Península Ibérica. Conforme ressaltado em citação anterior, ao final da narrativa, é já prenunciado o declínio do império muçulmano, antecipando-se a seguir, como disposto na citação abaixo, a retomada da Espanha pelos cristãos, restabelecendo-se aí, portanto, o enfoque endógeno:

Os que têm lido a história daquela época sabem que a batalha de Cangas de Onis foi o primeiro elo dessa cadeia de combates que, prolongando-se através de quase oito séculos, fez recuar o Alcorão para as praias da África e restituir ao evangelho esta boa terra de Espanha, terra, mais que nenhuma, de mártires. (HERCULANO, 1996, p.138)

Como visto, além da primeira expressão antagônica entre mouros e godos, ao longo da narrativa, acompanha-se, ainda, uma oscilação nas formas de caracterização de cada um desses povos. As circunstâncias definidoras das relações entre uns e outros parece dar o tom da diversidade como são figurados em cada contexto. Quando descritos os conflitos bélicos, apresenta-se, geralmente, uma equivalência referente à destreza, valentia e coragem dos dois exércitos, anunciando-se também, de maneira geral, uma equiparação numérica entre os seus membros e, ainda, uma similaridade entre os componentes dos diversos níveis hierárquicos aí presentes. Por outro lado, com relação aos valores morais, há um evidente privilégio dos estatutos cristãos em comparação com os muçulmanos, destacando-se, principalmente, a imoralidade dos árabes traduzida por seus excessos sexuais. Mas, nesse âmbito, coloca-se, ainda, um importante complicador, os godos traidores, que, embora tenham aderido ao exército muçulmano, permanecem cristãos, têm atitudes reprováveis até mesmo pelos árabes. 
Promove-se, assim, uma relativização da religiosidade e valores cristãos, associados à corrupção e decadência, e também islâmicos, que chegam a alcançar determinado nível de coerência e legitimidade. E, como já apontamos, os godos traidores poderiam, de fato, ser considerados os verdadeiros antagonistas, por serem responsabilizados pela decadência dos costumes e pela própria perda da península para os árabes.

Mas, há que se ressaltar, principalmente, a figuração do mouro como instrumento do castigo divino à decadência moral dos habitantes da Espanha. Tal configuração implica, realmente, outro comprometimento de sua representação como antagonistas, tornando-os parte de um plano que tem em sua origem e fim, os povos cristãos. Os muçulmanos atuam, assim, como instrumentos provisórios de um projeto alheio a sua religião, tendo função meramente utilitária, e sendo, nesse sentido reificados. Dessa forma, para além das ressalvas e das diversas dobras que comprometem uma expressão simplesmente dicotômica da relação entre mouros e godos, pode-se inferir, da narrativa de Eurico, a ênfase em uma problematização endógena ao próprio cristianismo, mas que abarca, com alguma complexidade, o instrumento mourisco aí representado em seu poderio bélico, nos seus costumes e religiosidade. 


\section{CAPÍTULO III - OS OUTROS MOUROS DE HERCULANO}

\section{III.1 - O Monge de Cister: um protagonista mouro}

Embora date de 1848 a publicação, em volume, de $O$ Monge de Cister, boa parte da obra teria sido elaborada por volta de 1840 , sendo alguns de seus extratos ${ }^{6}$ publicados na revista $O$ Panorama, em 1841. O próprio Herculano, em nota final, explica que a lacuna existente entre a elaboração parcial do romance e sua finalização e publicação deveu-se, primeiramente, às "circunstâncias [...] que baldearam o autor no charco da vida pública" (HERCULANO, p.687, 1959).

Alexandre Herculano também atribui o adiamento à necessidade imperativa de escrever a História de Portugal, conforme explicado na declaração a seguir, colocada em terceira pessoa: "A cruz que o Senhor lhe impôs foi a monomania de escrever a história dessa terra com lealdade e consciência." (HERCULANO, p.687, 1959). Mas, como já foi mencionado em tópico anterior, a recepção da obra historiográfica de Herculano foi extremamente problemática devido, principalmente, à forma desmistificada como foi apresentada a batalha de Ourique.

Prosseguindo, então, sua explicação, o autor lamenta-se dramaticamente pelo ocorrido: “Acusavam-no, caluniavam-no santamente, chamavam-lhe maniqueu, iconoclasta, luterano; proclamavam-no traidor à pátria.” (HERCULANO, p.687, 1959).

\footnotetext{
$6 \quad$ “Antes do aparecimento, em 1848, dos dois volumes d'O Monge de Cister (...), vieram a lume n'O Panorama, quinto volume, referente ao ano de 1841, os três primeiros capítulos do romance (...)" (NEMÉSIO, 1977, p.XXV)
} 
E, depois de expor longamente a forma injusta como foi acolhida sua historiografia, revela que foi exatamente como reação ao lamentável episódio que ele decidiu retomar a elaboração de $O$ Monge de Cister:

Depois ergueu-se e prosseguiu avante resignado. Todavia, ao longo da agra senda que conduz ao seu calvário (porque o calvário já era a dezoito séculos a recompensa dos que falam a verdade), ia ruminando como remiria o escândalo que dera ao próximo. Tanto ruminou, que lhe veio uma idéia bendita. (HERCULANO, p.688, 1959)

A idéia, como ele declara logo adiante, era, obviamente, a complementação e publicação de $O$ Monge. Importa enfatizar aqui que a finalização do romance foi assim realizada em um momento de grande ressentimento e frustração do autor pela incompreensão e crítica dirigidas a sua exaustiva empreitada historiográfica. Inclusive, com relação a isso, Vitorino Nemésio, em sua introdução à obra, relembra os ditos de Teixeira de Queirós sobre o assunto:

Teixeira de Queirós (Bento Moreno), cuja ótica de escritor naturalista confere certa isenção ao seu julgamento benévolo sobre $O$ Monge de Cister, descobre-lhe, pela data da composição coincidente com a chamada polêmica de Ourique, uma intenção circunstancial: " $O$ Monge é pois, na sua nova forma, obra de combate". (NEMÉSIO, 1977, p.XIV)

Além das circunstâncias adversas que marcaram a constituição final do romance, lembramos, também, que boa parte do intervalo entre o momento inicial de sua elaboração e a data da publicação fora ocupado com a pesquisa e produção de uma extensa obra historiográfica.

Ainda que as declarações de Alexandre Herculano não possam, em si, esclarecer a complexa elaboração de $O$ Monge de Cister, nelas encontramos, todavia, indícios que corroboram e, mesmo, subsidiam algumas significações que pudemos 
depreender desse texto literário. Conforme tentaremos expor com maior rigor a seguir, a narrativa de $O$ Monge guarda especificidades, em seu enredo e estrutura, que a distinguem bastante de Eurico, o presbitero e também de $O$ Bobo. E, relacionado a esse fato, a figuração do mouro alcança aí contornos bem próprios.

A grande extensão da obra, publicada inicialmente em dois volumes, já demarca uma diferença patente em relação a todo o restante da produção literária do autor. E sua dimensão se traduz, também, em uma multiplicidade de acontecimentos, fatos e personagens que aparentam, eventualmente, ter apenas vínculos tênues com o desenrolar geral da narrativa. Além disso, o próprio discurso narrativo oferece variações que apresentam tanto uma expressão grandiloquente e dramática, quanto digressões irônicas sobre fatos banais, ou mesmo, um formato rígido e descritivo referente aos fatos historiográficos.

Sabe-se, entretanto, que a heterogeneidade de estilos e caracteres é atributo próprio do Romantismo, o qual, diversamente do padrão clássico, pode acolher, por exemplo, tragicidade e comicidade, simultaneamente, conforme, ressalta, abaixo, Ofélia Paiva Monteiro:

[...] os românticos se entregam, contra a norma clássica da homogeneidade estilística, à conciliação estética de "contrários" (nobre e vulgar, trágico e cômico, lírico e sarcástico), em nome da necessidade de dar expressões às antinomias que em si mesmos e na sociedade descobrem, e que, no seu gosto pelo original e na sua valorização do imaginário, cultivam freqüentemente o bizarro, $o$ grotesco e o excessivo. (MONTEIRO, 2003, p.22)

E, embora outras obras de Herculano, como O Bobo e Eurico, apresentem várias características consideradas românticas, parece-nos que principalmente, em $O$ Monge de Cister, se cumpre, de fato, a permissividade estilística apontada acima. No entanto, essa distinção em relação aos outros textos literários nos parece melhor 
justificada pela duplicidade da expressão autoral da narrativa de $O$ Monge, constituída em dois momentos diversos, 1840 e 1848, do que por alguma proposta estética deliberadamente adotada pelo autor. Essa perspectiva aparenta-nos ser mais coerente, por percebermos ao longo da narrativa um predomínio maior da dispersão - do discurso, dos caracteres e do enredo -, do que propriamente de uma multiplicidade esteticamente elaborada. Como veremos adiante, alguns personagens e situações se apresentam um pouco deslocados do fio condutor da narrativa. Mas, o aspecto que nos parece mais notável nesse sentido é mesmo a descontinuidade discursiva. Além da abundante presença de textos com fundo historiográfico, eventualmente desvinculados da trama ficcional, em alguns casos, chega a ocorrer um desacordo entre a ação das personagens e os fatos históricos descritos.

De fato, uma questão realmente importante a ser considerada na estruturação tão peculiar da obra é o espaço reservado para os elementos historiográficos. Já no prefácio, Alexandre Herculano justifica que o mote do romance viera-lhe através da observação da decadência dos monumentos arquitetônicos de Lisboa:

Foi uma dessas meditações artísticas que gerou o pensamento deste livro, o transmitir aos vindouros alguns fragmentos do passado. Um dia em que atravessava da Lisboa árabe para a Lisboa romana, da Alfama para o Castelo [...] (HERCULANO, p.451, 1959)

O texto serviria para resgatar um passado em ruínas representado pelo descaso em que se encontravam os marcos arquitetônicos da cidade de Lisboa. Herculano profere, nesse texto introdutório, um discurso bastante exaltado contra o progresso e a ilustração, responsáveis pela destruição do legado arquitetônico português: 
Com a rapidez da cólera ou da peste corre por todos os ângulos de Portugal e encasa-se em todos os povoados uma cousa hedionda e torpe que, inimiga do passado e do futuro, se chama ilustração [...] (HERCULANO, p.451, 1959)

Observa-se, porém, que, apesar de constar, com alguma frequência, na narrativa de $O$ Monge, descrições arquitetônicas referentes à Lisboa, particularmente das regiões do Rossio, Castelo e, principalmente, Alfama, a contextualização e as explicações dos fatos históricos e da estrutura social da época ganham enfoque ainda maior.

M. Fátima Albuquerque, no texto, “A obra novelística de Alexandre Herculano: da verdade histórica à poesia romântica", chama a atenção para a desproporção do componente historiográfico presente, de maneira geral, na obra literária herculaniana quando comparada às obras de Scott e Victor Hugo. Albuquerque ressalta ainda que, a "paixão descritiva pela História" (ALBUQUERQUE, 1999, p.70) é uma especificidade da obra de Herculano, diferindo-a do padrão geral apresentado em outros textos inseridos na categoria do romance histórico oitocentista, que longe dos detalhamentos históricos pretendiam apenas uma "simples observação do real pitoresco" (ALBUQUERQUE, 1999, p.70).

Mas mais do que isso: esta minúcia histórica vai mesmo contra uma das técnicas mais desenvolvidas pelo gênero supracitado, já que as narrativas se deviam desenvolver, articulando momentos capitais da ação, reduzindo a descrição à cor local, atribuindo-lhe função de cenário. (ALBUQUERQUE, 1999, p.70)

E, ainda mais do que em Eurico e $O$ Bobo as descrições dos monumentos arquitetônicos e históricos, como também os fatos historiográficos referentes ao quadro social da época, ocupam, em $O$ Monge de Cister, uma parcela bastante extensa texto. A 
peculiaridade da questão assenta-se sobre o fato de que essa narrativa não tem como foco nenhum um grande evento histórico, como a disputa territorial com os árabes, em Eurico, ou a fundação da nacionalidade portuguesa, pelas lutas entre Afonso Henriques e o conde de Trava, em $O$ Bobo. A proposta do romance, declarada inclusive por Herculano, é a descrição do quadro social português da época de D. João I.

Ana Cristina Correia Gil define da seguinte forma tal contexto referido em O Monge de Cister:

[...] o palco da ação é a corte de D. João I, onde se desenrolam os conflitos e intrigas que envolvem as diferentes classes sociais: nobreza, clero, burguesia e povo. Também aqui (como em $O$ Bobo) o que está em causa é a garantia da independência nacional, ameaçada pela nobreza partidária de Castela, o que é acrescido por um paralelo entre o passado e o presente, o século XIX de Herculano, dilacerado pela guerra civil e pela opressão. (GIL, 1999, p.79)

Comentaremos a seguir algumas situações que pontuam o desenvolvimento da ação narrativa, seguindo a ordenação, nem sempre disposta de forma cronológica, que se apresenta na obra. Tentaremos recuperar também, além do contexto factual, um pouco do próprio estilo apresentado no texto literário, através da introdução de algumas citações e comentários.

No início do enredo, um cavaleiro desconhecido, que depois seria identificado como Vasco, o protagonista da narrativa, se apresenta a Frei Lourenço e tem com ele uma longa conversa da qual só se comenta a despedida:

O que aí se passou ninguém soube; mas notou o porteiro que, quando o mancebo saiu, o velho veio acompanhá-lo, e que tanto o desconhecido como Frei Lourenço tinham as faces banhadas em lágrimas. (HERCULANO, p.455, 1959).

Depois de um ano, o mesmo cavaleiro volta a procurar o Frei, agora vestido 
como monge cisterciense, pertencente, portanto, à ordem de São Bernardo. Identificado nesse momento como Vasco, o monge abraça Frei Lourenço. Descreve-se aí o choro aflito de Vasco adiantando-se todo o conflito e a tormenta que acompanharão o personagem:

[...] Frei Lourenço, que breve sentiu as suas lágrimas (de Vasco) ardentes e abundantes transpassarem-lhe a grosseira estamenha do escapulário e da túnica e umedecerem-lhe o peito. [...] No coração de Fr. Vasco estavam ainda todas as paixões do século, tumultuosas, férvidas, corrosivas [...] (HERCULANO, p.456, 1959).

Sabe-se, então, que, durante este ano que decorreu, Vasco passou pelo noviciado, aconselhado por seu confessor a procurar o claustro, "como remédio único ao mal que o roia" (HERCULANO, p.456, 1959). Frei Lourenço pede que Vasco conte novamente os sofrimentos ocorridos em seu passado, como medida terapêutica para se livrar da dor.

Assim, pela voz dramática e sofrida do protagonista, se esclarecem os episódios ocorridos até então, e que constituem o motivo para o subsequente desenrolar da narrativa. Vasco teria lutado contra os castelhanos, há três anos, em Aljubarrota, ao lado de Mem Rodrigues para livrar a "[...] terra da pátria do estranho domínio [...]" (HERCULANO, p.457, 1959). Durante esse tempo, os pensamentos do cavaleiro se concentravam na certeza de reencontrar sua irmã Beatriz, seu velho pai, Vasqueanes, e sua amada, Leonor. Mas, ao voltar pra casa, Vasco descobre que seu pai morreu de desgosto ao saber que Beatriz fugira com um cavaleiro desconhecido, D. Vivaldo, que havia abrigado em sua própria casa. Ele fica sabendo, ainda, que sua noiva Leonor, embora tivesse concedido-lhe a mão, havia se casado com Lopo Mendes, por ser ele mais rico e importante que Vasco. E, como consequência de todas essas desgraças, Brites, a criada que era como uma mãe para ele e Beatriz, havia enlouquecido. 
Finalmente, o monge cisterciense conta que seu pai morrera pedindo que ele se vingasse daqueles que desonraram sua família. Obstinado com a idéia da vingança, Vasco parte, então, em busca de D. Vivaldo e Lopo Mendes.

Embora seu primeiro alvo fosse o sedutor de sua irmã, D. Vivaldo, ele acaba encontrando anteriormente, ao acaso, Lopo Mendes. Lopo recusa-se a participar de um duelo com Vasco e pede que lhe diga o nome, provavelmente, tendo em vista suas atitudes vis, para mandar algum algoz cuidar do assunto em seu lugar. Mas, depois de uma verdadeira caçada de Vasco a Lopo Mendes, o filho de Vasqueanes mata o sedutor de Leonor com dois golpes de punhal.

A narrativa retorna, então, ao ponto inicial, quando Vasco, já tornado monge, se encontra com Frei Lourenço e este lhe pede que conte o seu desgraçado percurso. O monge de Cister parece demonstrar agora um sofrimento ainda mais intenso e um grande remorso que, entretanto, não o fizeram desistir de concluir sua vingança. Fr. Lourenço tenta, então, dissuadi-lo de suas intenções. Ocorre aí uma interessante intervenção do narrador que, na mesma linha de Rousseau, contrapõe o indivíduo, Vasco, à sociedade. A argumentação propõe a defesa do monge como uma vítima do contexto social:

Também nós [o narrador] não protrairemos por mais tempo essa cena de luta moral, em que o virtuoso velho [Frei Lourenço] trabalhava por salvar um desgraçado [Vasco], que nascera bom e honesto, e que a sociedade fizera culpado. Mentirosa, corrupta e má, a vida social, cheia de erros, preocupações e vícios, danada nas instituições e nas leis, nas crenças e nos costumes, educa as gerações e os indivíduos, legando-lhes largo cabedal de perdição [...] vulto hediondo e informe chamado sociedade, para o qual não há, nem lei, nem punições, nem algozes. Semelhante ao nosso, semelhante aos que hão de vir era o século XIV; e Fr. Vasco, lançado na carreira do crime pelo pundonor de cavaleiro e de nobre, pela exageração de fortes paixões, era uma vítima das idéias de seu tempo, como tantos o são das do nosso. (HERCULANO, p.473, 1959). 
Alberto Ferreira, na obra, Perspectiva do romantismo português (1834 1865), disserta, entre outros assuntos, sobre a influência de Rousseau no Romantismo português. A afinidade de Alexandre Herculano com o filósofo iluminista, precursor do Romantismo, pode ser identificada, de maneira geral, pela forma como Rousseau se contrapõe à civilização em favor do humano individual:

[...] Rousseau, sem dúvida nenhuma um iluminista, revolta-se contra as razões da civilização, ou seja, da sociedade instalada pela monarquia feudal, despedaçando a ordem exterior existente em favor do sentimento íntimo, do instinto e da afetividade como bases originárias do que de mais sincero, espontâneo e natural exista no comportamento ou mesmo no ser humano. (FERREIRA, 1971, p.15)

Mas, retomando a situação em que se encontravam os dois religiosos, podese constatar que Fr. Lourenço consegue convencer Vasco a deixar de lado sua vingança. O monge dedica-se, então, com todo o afinco aos propósitos religiosos. Entretanto, como veremos a seguir, novos fatos acabarão por determinar outra guinada na instável pacificação das angústias de Fr. Vasco.

A nova etapa inicia-se quando um mouro procura Fr. Lourenço, pedindo-lhe que ouça a confissão de uma cristã que estava abrigada em sua casa. Quando se encontra com a cristã, na praia do Restêlo, onde ficava a casa do mouro, Fr. Lourenço descobre que ela era a irmã desonrada de Vasco, Beatriz. O frei providencia, então, para que ela tenha uma nova morada e também uma acompanhante: tia Domingas. Essa personagem já havia sido anteriormente apresentada, quando foi descrita uma festa popular ocorrida no Restêlo, em situação indigna, envolvida em intrigas e fofocas. O caráter pouco íntegro da beata, já exposto nesse contexto, é agora novamente ressaltado em uma insinuação irônica, quando o religioso entrega-lhe uma quantia para que tome conta de Beatriz: “[...] tia Domingas [...], cujos escrúpulos tinham sido completamente 
removidos com a vista da bolsa recheada de excelentes dobras e meias dobras Del Rei D. Pedro [...]". (HERCULANO, p.487, 1959).

Depois de contar a Vasco, quem era, de fato, a moça que pedira a confissão, mais uma vez, Fr. Lourenço precisa convencer o monge cisterciense de não proceder sua vingança contra a própria irmã. $\mathrm{O}$ frade usa para isso o seguinte argumento: "Se o fizeres [perdoar Beatriz], o Senhor se amerceará de ti: o teu amor criminoso extinguirse-á: os teus sonhos e remorsos desvanecer-se-ão [...] perdão!” (HERCULANO, p.488, 1959).

Fr. Lourenço, juntamente com Vasco, procura, então, o abade de Alcobaça, D. João d'Ornelas, e pede-lhe que interceda junto ao rei para que D. Vivaldo, cujo nome verdadeiro é D. Fernando Afonso, seja legalmente punido por ter desonrado e posteriormente abandonado Beatriz. $\mathrm{O}$ abade, que a princípio se mostra indiferente ao problema, quando descobre quem era o raptor da irmã de Vasco, toma interesse súbito pelo caso. No capítulo anterior, intitulado "O Abade de Alcobaça", este importante personagem, extraído dos fatos oficiais da História portuguesa, é apresentado nesse contexto narrativo, em uma descrição bastante detalhada que conjuga o seu desempenho histórico com um julgamento subjetivo e, em boa medida, fictício, de sua personalidade, como se pode verificar, por exemplo, no seguinte excerto:

Elevado a tal grau de poderio e dotado de caráter violento, ambicioso, altivo para com os grandes, opressor para com os pequenos, D. João d'Ornelas chegara a obter a triste distinção de ser temido e odiado em geral por pequenos e grandes, principalmente por vassalos do mosteiro, que vexava sem piedade. (HERCULANO, p.488, 1959)

É interessante notar que, contrariamente aos preceitos do romance histórico oitocentista, nessa obra de Herculano, um personagem bastante destacado da História oficial atua também como figura importante da trama narrativa, desempenhando o papel 
de vilão, e atuando como um dos principais responsáveis pelos descaminhos do protagonista, Vasco.

Mas, retomando a sequência narrativa, após o encontro entre os três religiosos, Fr. Lourenço pede a D. João d'Ornelas que tome conta de Vasco, pois ele apresenta-se ainda transtornado com os acontecimentos. Quando fica a sós com o monge, o Abade de Alcobaça, em uma conversa ardilosa, na qual avalia as verdadeiras intenções de Vasco, revela a ele o ódio que também nutre em relação a Fernando Afonso. Descreve-se então, de forma um tanto dramática e aterrorizante, o pacto de ódio e vingança estabelecido entre o Abade e Fr. Vasco:

Com as faces incendiadas e os olhos banhados em alegria feroz, os dois monges, conversando assim juntos à luz avermelhada das tochas com que se alumiava esta cena, formavam um quadro semelhante àquelas visões fantásticas, repugnantes e dolorosas, que passam em nossa alma, quando por noite de febre nos aperta o coração longo e aflitivo pesadelo. (HERCULANO, p.502, 1959)

D. João d'Ornelas leva Vasco à Tavolagem do Besteiro, na qual, entre outros cavalheiros, encontrava-se Fernando Afonso. O abade e o sedutor da irmã de Vasco trocam diversas provocações, e, após essa cena tensa, em que uma vez mais os intensos sentimentos de vingança de Vasco são ressaltados, o capítulo justaposto, "Doctor Mater-Gala", apresenta com ironia aguda, o personagem Mem Bugalho, que também estava presente na tavolagem. A descrição física de Mater-Gala inicia-se da seguinte forma:

Prima facie, dir-se-ia que era um cepo d'açougue, equilibrado por mecanismo oculto sobre duas achas de pinho, e servindo de pedestal a uma abóbora moganga para cima da qual se houvesse atirado ao desdém a cabeleira ruça e cerdosa de um desembargador da antiga Mesa da Consciência ou da Casa da Suplicação. Esta cousa com pretensões de figura humana vinha ensacada em um gibão de engrês preto [...] (HERCULANO, p.517, 1959). 
E a apresentação do personagem continua nesse tom, hora escrachado, ora elegante, prosseguindo em uma longa preleção referente à patética transformação elaborada por Mem Bugalho de seu codinome Pataburro em Matter-Galla-DictusAsinipes. E para concluir o assunto, o narrador, envolvendo-se em um diálogo direto com o leitor, no qual evoca com desprezo bem-humorado os críticos portugueses, faz a seguinte colocação:

Se o leitor achar um pouco estranhas estas particularidades biográficas do licenciado Mater-Galla-Dictus-Asinipes ou Mem Bugalho Pataburro, dir-lhe-emos que redondamente se engana. Se o apresentássemos em público sem dar explicações acerca de seu nome, aparentemente extravagante, saltavam-nos todos os críticos de fôlego curto e letras rabudas que há nesta bem-aventurada terra de Portugal; e nós respeitamos sobremodo os ditos críticos; porque de mais ciência, tato e agudeza não cremos que se achem em todo o mundo, sem excetuar o reino de Pegu, a Polinésia e a Cafraria. (HERCULANO, 1959, p.517).

A presença do personagem na trama prolonga-se, ainda, em uma cena ao mesmo tempo divertida, triste e patética, na qual as ilusões de grandeza de Mem Bugalho são totalmente desfeitas ao se evidenciar o desprezo dos cavaleiros presentes na tavolagem que o trataram como uma figura ridícula e risível. Acentua-se, também nessa cena, a corrupção, os mecanismos ilícitos e acordos interesseiros que predominavam entre os nobres. Depois de retirar-se, revoltado com a humilhação sofrida, Mem Bugalho é procurado por Vasco, a mando de D. João d'Ornelas. Entre os três cavaleiros estabelece-se agora, também, um pacto de vingança.

Nota-se, na cuidadosa apresentação do personagem Mater-Galla-DictusAsinipes, que ganha inclusive um capítulo inteiro dedicado a ele, o cuidado com os detalhes narrativos e o gosto pela elaboração discursiva. Teófilo Braga, entretanto, faz a seguinte observação sobre o personagem de Herculano: "O Mater-Galla ou o doutor 
Pataburro, d'O Monge de Cister, é a amostra do esforço violento do espírito de Herculano para ter graça.” (BRAGA, p.219, 1977). Mas, como já foi visto anteriormente, as críticas de Braga à obra de Herculano mostram-se, com frequência, bastante injustas, ou conforme descreve B. Capelo Pereira, o crítico "num ressentimento faccioso, envereda mesmo pela calúnia" (PEREIRA, 1997, p.222)

Retomando, então, os fatos componentes da trama narrativa, um acontecimento importante, ocorrido pouco depois do episódio da Tavolagem do Besteiro determina, certamente, o modo como o destino de Vasco se encaminha. Referimo-nos a saída de cena de Fr. Lourenço. Notando a influência benévola e pacificadora que ele tinha sobre Vasco, D. João d'Ornelas trata de separá-los, enviando “[...] o Mestre da Teologia por visitador aos mosteiros de Carquere e Bouro, sob o pretexto de que a vida monástica aí corria soltamente fora dos preceitos austeros da regra de S. Bernardo. O monge obedecera.” (HERCULANO, 1959, p.542).

Vasco, entretanto, mesmo sem a presença benfeitora de Fr. Lourenço, deixase comover pelo sofrimento de sua irmã Beatriz e decide tentar obter a oficialização do casamento entre o camareiro do rei, Fernando Afonso, e a sua irmã. No seguinte trecho o monge explica à Beatriz o seu intento de solucionar de forma pacífica a situação de desonra em que se encontrava sua família:

Era sangue o que devia remir a sedução; mas o sangue que lava a beta negra traçada na fronte golfa para o coração do assassino e assinalalho com outra beta mais cruel e mais negra, que pouco a pouco se vai irradiando e o devora. Poupemos o sangue e tentemos ainda!... Fernando salvará a tua honra, a honra de nosso pai e a minha própria, se é coisa em que deva pesar quem traja em vida mortalha. [...] Que te diga diante do mundo - "tu és minha mulher" - e que depois te abandone, te deteste. Que te importa ou que me importa? (HERCULANO, 1959, p.553)

Mas, o plano de Vasco para atrair Fernando Afonso, para sua casa acaba 
ocasionando a morte de tia Domingas. A ajudante de Beatriz, incumbida de se aproximar do o camareiro do rei durante a procissão de Corpus Christie e atraí-lo para a casa em que se encontravam Vasco e sua irmã, acaba tendo com ele um encontro tumultuado, no qual ela é pisoteada é morta pela mula, na qual estava montado Fernando Afonso: "Esmagada debaixo dos pés da mula arquejava apenas, e o sangue rebentava-lhe em fio da boca, dos olhos e dos ouvidos." (HERCULANO, 1959, p.601).

Com a morte de tia Domingas, o plano inicial de Vasco fracassa, e Beatriz, que se encontrava bastante adoentada, consegue persuadi-lo a jurar que perdoaria as ofensas de Fernando Afonso, acreditando assim salvar a alma de seu irmão. Pouco depois da promessa feita a contragosto por Vasco, Beatriz falece.

O monge, então, entra em estado de completo desespero e revolta. D. João d'Ornelas aproveitando-se da desesperação ainda mais aguda em que se encontrava Vasco e sentindo que ele vacila, entre a vontade de vingança e o compromisso do perdão de Fernando Afonso, lhe revela outro fato que sabia ser absolutamente doloroso para Vasco: a atual amante de Fernando Afonso, por quem ele deixara Beatriz, era Leonor, a mulher amada por Vasco e que traíra casando-se com outro.

Essa informação foi obtida pelo abade de Alcobaça através do mouro Alé, que tempos antes ele conseguira introduzir na corte de D. João I, para “[...] exercer o cargo que deixara vago o falecido bobo e jogral de D. Fernando e de D. João I, o célebre Anequim.” (HERCULANO, 1959, p.604). Evidentemente, a intenção real de D. João d'Ornelas era, de fato, tomar conhecimento, através de Alé, do que acontecia no paço real, principalmente no que se referia a Fernando Afonso e sua misteriosa amante.

O fato novo deixa Vasco ainda mais perturbado e transtornado de ódio, permitindo que o abade de Alcobaça passe a conduzir a seu modo a vingança contra o 
amante de Leonor. O seguinte excerto traduz bem o descontrole do monge, que em uma cena violenta atira o próprio crucifixo da cama de sua irmã:

Fr. Vasco estendeu devagarinho a mão, pegou no pé da cruz e, girando com ela em volta, como o fundibulário com a funda de que vai despedir a pedra, arremessou-a para longe. Os fragmentos da lâmpada voaram em rachas com multiplicado tinir, a imagem da Virgem rolou em pedaços do seu pedestal, e o crucifixo bateu na parede com um som embaçado. (HERCULANO, 1959, p.634)

Seguindo, então, o plano arquitetado por Joao d'Ornelas, Vasco comparece ao sarau realizado no paço real e fazendo-se o centro das atenções cai de joelhos diante do rei D. João I pedindo justiça. O monarca em atitude generosa e complacente decide ouvir a denúncia do monge. Assim, diante do Mestre d'Avis e de todos os presentes no sarau, Vasco conta todas as desgraças acontecidas com ele e com sua família desde o retorno de Aljubarrota, revelando também, a participação criminosa do camareiro preferido do rei, Fernando Afonso, em tais episódios. Desconsertado pela situação, D. João I diz que antes de tudo era preciso comprovar a culpa do camareiro, o que se dá, de outro modo, logo em seguida, com a intervenção já planejada de Alé.

O mouro, instruído por D. João d'Ornelas, atrai o rei e todo o seu séquito para os aposentos pertencentes às damas da corte, com a denúncia de que um estranho adentrara o espaço reservado. O estranho que era, evidentemente, Fernando Afonso foi então flagrado e condenado a morte. Com grande pesar, devido ao forte laço de amizade que os unia, o Mestre d'Avis, entretanto, cumpre o decreto esperado para tal caso pronunciando as seguintes palavras: "Mandai levar este homem aos sótãos de alcáçova. Depois, um poste sobre uma pilha de lenha no rossio de Valverde pronto ao romper d'alva. Perecerá pelo fogo o servo que afrontou seu senhor..." (HERCULANO, 1959, p.658). 
Mas, prosseguindo o plano ainda mais maquiavélico que o Abade de Alcobaça traçara com Vasco, o criminoso fora retirado da prisão e levado para a Igreja onde se encontrava o corpo de Beatriz. Em um episódio bastante sombrio Vasco faz com que o antigo amante da irmã confesse os delitos cometidos, mas o fato de Fernando Afonso recusar-se a falar de Leonor e, novamente, ofender a honra de Beatriz, deixa o monge cisterciense ainda mais enraivecido, o que pode ser verificado nas seguintes palavras proferidas por ele:

Hei de lançar-te deste asilo, como uma coisa torpe e imunda. Hei de entregar-te aos que te espreitam, semelhantes aos monteiros que aguardam o javali na clareira das brenhas. Hei de acompanhar-te ao cadafalso, oferecendo-te em voz alta as consolações da religião e insultando-te em voz baixa. Com a mordaça na boca, amarrado ao poste, quando o fogo se te enredar nas roupas, quando as carnes se te despregarem dos ossos, e os ossos te estalarem como um toro incendido, ouvir-me-ás amaldiçoar-te... Moribundo, desesperado, estorceres-te na derradeira agonia, soltando a suprema blasfêmia, ajudar-te-ei com as minhas maldiçoes a dar a alma aos Demônios. (HERCULANO, 1959, p.672)

E, de fato, tal ameaça se cumpre. Sendo designado para acompanhar o condenado, Vasco pode realizar o último, e talvez mais vil, ato de sua vingança. E, no Capítulo XXX, posposto à conclusão, apresentam-se a morte do monge cisterciense, a confissão feita ao atual Pároco de sua aldeia natal e a proibição de seu sepultamento nas terras da igreja. Ao final desse capítulo, é descrito, também, o retorno de Fr. Lourenço a sua terra. Depois de ler uma carta, que teria sido escrita por Vasco, o Mestre de Teologia passa a apresentar o comportamento entristecido e estranho, conforme descrito no último parágrafo da narrativa: 
Uma cousa notável foi que Fr. Lourenço não tornou a rir em dias de sua vida. Quando, ao chegar à Estudaria, tinha recebido a notícia do singular desaparecimento de Fr. Vasco, o Mestre de Teologia protestara que ele saberia descobrir se o moço frade era morto ou onde parava. Vãos protestos! Nunca mais em tal falou; nunca mais, até, proferiu o nome do pobre monge; e se aludiam a ele, mudava de conversação, ou retirava-se. Fosse efeito da idade, fosse por estar gasto de longos trabalhos mentais, o espírito do Bacharel decaiu rapidamente. Consumia horas e dias a passear sozinho na crasta, e a sua mania era repetir muitas vezes a sentença do Evangelho: "Se não perdoardes, também Deus vos não perdoará.” (HERCULANO, 1959, p.686)

Destacamos, assim, os principais eventos componentes da trama narrativa, mas importa ressaltar, ainda, algumas peculiaridades do estilo com o qual foi elaborado O Monge de Cister. Conforme se pode depreender, parcialmente, das citações dispostas acima, a obra apresenta uma confluência de padrões que lhe conferem tanto a feição austera e grandiosa, impregnada de metáforas exaltadas, como um aspecto mais irreverente e coloquial, no qual prevalece o tom irônico.

Exemplo significativo da conjunção de tais estilos pode ser verificado na justaposição de uma longa digressão referente ao valor majestoso de Lisboa seguida da abordagem direta do leitor em um diálogo jocoso. A digressão contempla uma metáfora da cidade como a filha inocente e preferida do rei D. Fernando, que enriquece nos séculos XV e, principalmente, XVI, alcançando o seu auge, mas perdendo depois disso todas as virtudes e valores. Concluindo de forma amarga a longa divagação, o narrador evoca a época de D. João I. Destacando aí um exemplo a ser seguido pelo futuro, mas já prevendo o desprezo do leitor por tal monarca faz a seguinte colocação:

D. João I?! Ora essa - exclamará algum dos nossos leitores. - Deixainos com D. João I! Pobre bruto, que não sabia nem conhecia nada: nem os falanstérios nem os charutos de Havana; nem a mnemotécnica nem a pirotécnica; nem o sistema eleitoral nem as pílulas de família; (HERCULANO, p.476, 1959). 
$\mathrm{E}$, encerrando esse trecho, com ironia semelhante àquela tão celebrada tempos depois em Machado de Assis, o narrador lança ao leitor a seguinte réplica para o imaginado diálogo: "Tens razão, leitor. Fecha o livro que não é para ti." (HERCULANO, 1959, p.476).

Em O Monge de Cister, notamos, mais uma vez, um deslocamento considerável em relação aos valores exemplares e heróicos comumente atribuídos à obra herculaniana. Conforme já foi prenunciado no tópico referente a Eurico, observamos que os críticos, não raro, destacam a correspondência entre o herói e a nação na ficção histórica de Alexandre Herculano. Um exemplo disso pode ser constatado nas seguintes palavras de Helena Carvalhão Buescu, que aborda, também, a representatividade do herói e os ideais coletivos encerrados em sua figura, sempre destacada em relação ao grupo a que pertence:

[...] o entendimento da Nação enquanto ser dinâmico, dotado de uma energia vital e transformadora, capaz de se assumir e afirmar. [...] criando uma narrativa cuja ação apresente um herói que simbolicamente constitua a representação de um ideal de grupo e que, ao mesmo tempo, reivindique para si a defesa intransigente dos princípios da liberdade. É este o princípio norteador da narrativa histórica que Alexandre Herculano, inspirado nos modelos de Dumas mas sobretudo Walter Scott, vai modelando nos vários contos e nos vários romances que publica. [...] É neste quadro que o romance histórico aparece a Herculano [...] como campo privilegiado para a execução narrativa de pressupostos ideológicos e estéticos de que o Romantismo nasce e a partir dos quais se desenvolve: pelo que permite de concentração do fluxo e da tensão narrativa em torno de um sujeito, individualidade capaz de se demarcar em relação a outros através de instrumentos que facilitam a sua oposição, a sua luta e, consequentemente, a sua marginalização e solidão; mas também pelo que permite de identificação do destino pessoal e do destino nacional - e isto porque, sendo herói, ou seja, "marcado", o seu destino é inegavelmente público, extraordinário, e portador inequívoco de uma carga simbólica; [...] (BUESCU, 2005, p. 151-152)

Mas, aceitando tal hipótese referente à representatividade nacional através da figura do herói, em $O$ Monge de Cister, pensamos qual seria, então, a caracterização 
nacional contemplada por Vasco. E, antes disso, quais seriam, de fato, os valores heróicos inerentes a esse personagem. Como foi visto, o monge cisterciense, além de caracterizado pela valentia, coragem, integridade e pelas ações honrosas em relação a sua pátria, ao seu pai e irmã, apresenta ainda um lado bastante soturno resultante das terríveis perdas e desilusões sofridas. Mas, também em Eurico, o herói paradigma da geração romântica, está presente essa sombra de amargura, melancolia e instintos bárbaros, que parecem bem traduzidos em sua alcunha de Cavaleiro Negro.

Há, entretanto, um aspecto que diferencia nitidamente a heroicidade terrível e grandiosa do presbítero, dos excessos violentos praticados por Vasco. A partir de determinado momento da narrativa, quando sua irmã, Beatriz, morre, - e D. João d'Ornelas, em uma longa argumentação, na qual expõe, entre outras coisas, a relação entre Leonor e Fernando Afonso, convence Vasco a perpetrar sua vingança - o monge parece, finalmente, ultrapassar o limite do que seria nobre e aceitável, apesar de violento, e passa a atuar de maneira infame.

Lembramos que em sua última conversa com Beatriz, mesmo depois de já ter, há algum tempo, assassinado Lopo Mendes, a auto-imagem de Vasco conservava, ainda, traços de honradez: "Oh, eu que fui nobre, que fui cavaleiro; eu que jamais cometi feito vil, que nunca nos combates voltei as costas [...]" (HERCULANO, p.620, 1959). Se os títulos de nobre e cavaleiro pertencem já ao passado, fica claro, entretanto, que Vasco considerava-se, de alguma forma, honrado, pois nunca chegara a ser vil.

Pouco mais adiante, outro excerto corrobora, também, a preservação do caráter religioso de Vasco, o que neste contexto representa, evidentemente, uma característica bastante positiva: "Apesar dos seus desvarios, Vasco nunca deixara inteiramente de crer na misericórdia de Deus." (HERCULANO, 1959, p.624). Essas 
colocações parecem, de fato, demarcar um momento crucial da trajetória do protagonista, no qual, para lá das oscilações morais, em que se preservava, entretanto, um vestígio de honradez, ele alcança, agora, o âmbito da vileza.

Mas, é também um fator importante e, de certa forma, atenuante desse contexto, a atuação incisiva de D. João d'Ornelas na transformação sofrida por Vasco. As estratégias de convencimento e a argumentação coerente do Abade de Alcobaça evidenciam a manipulação sofrida pelo monge e, por isso, ele seria também, em alguma medida, vitimizado.

Conforme exposto anteriormente, na linha rousseauniana, perpetrada algumas vezes por Herculano, o indivíduo pode ser compreendido como vítima da sociedade e, nesse caso, D. João d'Ornelas parece, realmente, representar a sociedade hipócrita e corrupta, e, considerando sua função religiosa, isso poderia ser estendido também como crítica ao âmbito da igreja.

Ana Cristina Correia Gil, como muitos outros autores, destaca a função didática e pedagógica dessa obra de Alexandre Herculano, na qual se buscaria “[...] dignificar e celebrar as origens da nação portuguesa e, a par desta exaltação do passado, apontar os erros do presente." (GIL, 1999, p.78). Sobre a relação entre passado e presente para Herculano, Gil declara ainda o seguinte: “O romance histórico e a arte em geral estão, em Herculano, ao serviço da pedagogia da nação, pondo a nu a apatia e a decadência do tempo presente por comparação com o vigor e a glória passados." (GIL, 1999, p.78). Correia Gil vê em Afonso Henriques e D. João I, personagens de $O$ Bobo e de $O$ Monge de Cister, respectivamente, exemplos da função didática patente nas obras herculanianas. Segundo Gil, essas 
[...] figuras exemplares da História de Portugal [...] não são apresentadas como personagens centrais do enredo, de acordo com o que exige o romance histórico no caso de personagens históricas, mas cuja apresentação é feita de modo a surgirem enaltecidas e enquanto símbolos da defesa da unidade nacional, bem como da independência política." (GIL, 1999, p.79)

A autora destaca, ainda, a dimensão negativa dos personagens antagônicos

nessas obras, que assumiriam uma caracterização perversa e antinacionalista:

[...] as personagens que ameaçam o espaço nacional têm em ambos os romances uma forte carga negativa, criando o autor uma cosmovisão muito própria, marcada por um quase maniqueísmo: os "bons", os patriotas, contra os traidores da nação. (GIL, 1999, p.79)

Mas, Correia Gil, que anteriormente destacara o maniqueísmo presente em O Monge de Cister, reconhece que nessa obra não há uma polarização entre portugueses e castelhanos, "[...] uma vez que tudo se desenrola no seio da sociedade portuguesa" (GIL, 1999, p.81). Para ela, o inimigo estaria situado no seio da própria sociedade portuguesa, e seria constituído, principalmente, pela nobreza:

No entanto, a nobreza é apresentada como uma classe traidora, acusada ao longo da obra, sobretudo por João das Regras, seu inimigo por excelência, de combater por Castela [...], ao mesmo tempo que vive na devassidão e no luxo, oprimindo o povo, de quem exige impostos indiscriminadamente e sendo insolente para com o rei. Assim, é esta classe que representa a ameaça que paira sobre a independência do país e Fernando Afonso, o camareiro-menor de D. João I, é o seu representante, caracterizado de modo muito pejorativo: sedutor inveterado e de caráter dissimulado, leva uma vida dupla, aparentando ser virtuoso e dedicado e sendo, de fato, vicioso e dissoluto [...]" (GIL, 1999, p.81).

Correia Gil percebe também, com muita argúcia, a presença de uma personagem, como ela mesma diz, "muito secundária que só surge numa cena" (GIL, 1999, p.82), João Rodrigues de Sá, que representaria a voz dissonante no contexto vicioso e corrupto da nobreza: "perante as ações ilegais da sua classe, ele é o nobre 
honrado a quem envergonham as desonestidades dos seus iguais" (GIL, 1999, p.82). A autora acrescenta a esse fato outras situações e personagens que representariam, ao mesmo tempo, a virtude e o vício, concluindo daí que tanto a nobreza, quanto o clero e a burguesia estariam representados em um "retrato heterogêneo" (GIL, 1999, p.82) e que apenas “D. João I e o povo" sairiam "ilesos da crítica do narrador" (GIL, 1999, p.83).

A nossa percepção sobre o quadro social apresentado na novela de Herculano, entretanto, diverge em alguns pontos da perspectiva de Ana Cristina Correia Gil. Mais do que o maniqueísmo e a heterogeneidade dos personagens destacados pela pesquisadora, percebemos a grande predominância de uma caracterização negativa tanto do clero, quanto da nobreza, da burguesia e, em alguma medida também, do povo. As únicas exceções, a nosso ver, seriam Fr. Lourenço, que é rapidamente retirado do enredo, e José Rodrigues de Sá, que tem uma participação instantânea e poderia, mesmo, passar desapercebido na grande extensão narrativa. Já D. João I tem uma caracterização que tende a ser positiva, mas não chega a realizar nenhuma ação verdadeiramente grandiosa ou heróica.

E o tom sutilmente irônico, inesperado para a narrativa de Herculano, parece ter causado também um equívoco; Correia Gil vê em João das Regras um personagem com características dúbias, pois, em suas palavras: "O narrador oscila de opinião perante esta personagem: tanto o apelida de "santo e pacato homem", como diz ter o coração "frio e árido" [...]”(GIL, 1999, p.83). E, dessa forma, Gil aponta na burguesia, através de João das Regras, também uma ambiguidade de caráter. Mas, entendemos que o apelido, "santo e pacato homem", expressa, na verdade, uma grande ironia, também utilizada pelo narrador em diversos outros momentos, ao empregar designações elogiosas, para fazer significar exatamente o contrário. 
Já no que se refere à representação do povo na narrativa, parece-nos prevalecer uma expressão de condescendência. Apesar da caracterização depreciativa e algumas vezes grotesca das classes populares, os defeitos que lhe cabem aparentam ser menos significativos que os da nobreza, clero e burguesia, como, por exemplo, as intrigas, ambição, inveja e fofocas. Entre os populares poder-se-ia, também, considerar o mouro Alé e a moura Zilá, que, embora referidos em situações burlescas, não chegam a praticar ações verdadeiramente reprováveis. A sensação de "imunidade" em relação ao povo, talvez, se dê pela ausência de um discurso do narrador que, de fato, o condene, como ocorre comumente com as outras classes.

E, finalmente, com relação ao protagonista que, para Correia Gil e outros críticos, representaria, no conjunto da obra de Herculano, o paradigma do Bem, associando-se, ainda, à heroicidade do passado nacional, identificamos, entretanto, um deslocamento irreversível para o âmbito do aviltamento. A prova final se dá quando o padre da aldeia natal de Vasco, devido à grave heresia por ele cometida e confessada, declara que o Monge cisterciense já não poderia ser enterrado nas terras da igreja.

É interessante notar que entre os três protagonistas, dos três romances históricos de Herculano, Vasco é o único que ultrapassa, de fato, o limite do aceitável. Se Eurico contém um lado sombrio e D. Bibas aparenta estar além de qualquer restrição moral, é apenas Vasco que, pertencendo a um contexto valorativo definido, extrapola, realmente, seu padrão de conduta. E é, portanto, bastante significativo, que seja ele, também, o único protagonista de tais narrativas, caracterizado com traços mouros, pois, conforme veremos adiante, logo no início do texto literário, diz-se o seguinte sobre o Monge: “[...] nessas veias corria o sangue de um árabe.” (HERCULANO, 1959, p.454).

Da mesma forma que esse herói "falha", a nação por ele representada 
aparenta, também, falhar. E tal contexto parece, realmente, não poder sustentar expressões de heroicidade ou paradigmas morais e nacionais a serem seguidos, revelando apenas sintomas de desencantamento por uma ordem injusta, na qual prevalece a mentira, corrupção e ambição. Assim, entendemos que a relação entre o passado retratado em $O$ Monge de Cister e o presente de sua enunciação sugere mais um vínculo de espelhamento do que a oposição apontada por Ana Cristina Correia Gil e pela grande maioria dos críticos, que enxergam no passado heróico abordado por Herculano um exemplo para o presente em decadência.

Mas, como veremos a seguir, tanto o herói falido, como a nação decadente, por ele representada, apresentam em sua composição uma faceta mourisca. Já no início da narrativa há uma alusão a presença da etnia árabe como contributo formador dos portugueses, quando se comenta as feições do protagonista, Vasco. Conforme já mencionado, após descrever sua aparência, identificando-lhe a tez morena, o narrador faz a seguinte constatação: "No rosto do mancebo estava escrito o nome da sua terra natal: era um filho das Espanhas: a cor, o gesto, o olhar, tudo dizia que aí dentro havia o espírito de um godo e, ao mesmo tempo, que nessas veias corria o sangue de um árabe." (HERCULANO, 1959, p.454)

Diversamente da temática de Eurico, o conflito histórico, aludido em $O$ Monge de Cister, refere-se à luta entre portugueses e castelhanos em Aljubarrota e não mais à disputa territorial com os árabes. Também aqui podemos perceber que os opositores da nação, agora os castelhanos, são tomados na construção narrativa como elemento de comparação e analogia com os antagonistas, no caso abaixo, os inimigos de Vasco, como se pode acompanhar na voz do próprio protagonista: 
A minha boa espada tinha de ir bater sobre uma cabeça criminosa, como maldição paterna lançada do leito da morte; como os pelouros desses trons ruidosos com que os castelhanos rareavam nossas alas em Aljubarrota, sem haver arnês que lhes resistisse, elmo que, ao perpassar deles, não voasse em rachas com o crânio de seu dono. Qual devia ser a primeira? Hesitei. Lembrei-me da palavra que me legara meu pai: procurei o sedutor de Beatriz. (HERCULANO, 1959, p.465)

Da mesma forma, as outras referências aos castelhanos ocorrem sem maiores considerações valorativas ou morais, diversamente do que acontece em Eurico, nas várias menções aos costumes torpes dos mouros infiéis. Aqui, além da Batalha de Aljubarrota já ter acontecido - no início da narrativa, Vasco acaba de retornar da batalha -, a crítica, no que concerne à disputa com os castelhanos, recai sobre os nobres portugueses que oscilaram e muitas vezes apoiaram Castela. Ana Cristina Gil chama a atenção para esse fato acrescentando uma explicação bastante coerente para tal:

Enquanto que em $O$ bobo o sentido patriótico leva Herculano a opor as virtudes dos portugueses aos defeitos dos castelhanos, em $O$ monge de Cister esta dicotomia não é possível, uma vez que tudo se desenrola no seio da sociedade portuguesa. No entanto, a nobreza é apresentada como uma classe traidora, acusada ao longo da obra, sobretudo por João das Regras, seu inimigo por excelência, de combater por Castela [...] ao mesmo tempo que vive na devassidão e no luxo, oprimindo o povo, de quem exige impostos indiscriminadamente e sendo insolente para com o rei. Assim, é esta classe que representa a ameaça que paira sobre a independência do país e Fernando Afonso, o camareiro menor de D. João I, é o seu representante, caracterizado de modo muito pejorativo [...] (GIL, 1999, p.81)

Dessa forma, sendo o conflito referente à questão nacional, ocorrido entre portugueses e castelhanos, e, de modo ainda mais significativo, ficando no interior da própria sociedade portuguesa, mais especificamente com a nobreza, a responsabilização pela decadência e corrupção nacionais, a figuração dos mouros nessa obra coloca-se, de fato, fora do plano antagônico principal. Conforme veremos adiante, a presença moura no romance se dá, principalmente, através de alusões às comunidades mouriscas 
pertencentes às classes populares, de algumas poucas referências arquitetônicas, componentes da ambientação de fundo, e, de forma particularizada, dos personagens mouros Alé e Zilá.

A primeira referência, de fato, a um personagem designado como mouro, ocorre quando Vasco, ao iniciar a busca pelos traidores de sua família, depara-se com uma cena bizarra envolvendo o truão mouro, Alé. O truão, que a princípio divertia um grupo de pessoas, em uma pequena apresentação de pantomimas e cantigas, é repentinamente atacado por dois cavaleiros ao aperceberem-se de que ele era mouro. Ao ser chamado de cão pelos dois atacantes o truão replica com a seguinte frase: "A maldição do Profeta caia sobre vós, infiéis!” (HERCULANO, 1959, p.466). E essa declaração fez com que as outras pessoas se revoltassem e também o atacassem, jogando pedras e xingando o truão: "Perro, por que não fugiste? - gritavam uns." (HERCULANO, 1959, p.466).

Vasco, ao presenciar a cena, é acometido por um inesperado compadecimento em relação ao mouro, o qual ele mesmo elabora da seguinte forma:

Um ano antes teria rido, como os mais, da desventura daquele mesquinho; mas tudo em mim estava mudado. Acreditareis, virtuoso Fr. Lourenço, que eu, cavaleiro de Cristo, tive dó de um mouro e amaldiçoei os dois nobres?

Vis sandeus, - disse em voz baixa - deixam passar os poderosos que oprimem, e escarnecem do agravado, porque é um pobre mouro! Porventura essa reflexão nascia de que eu também era opresso. Também cavaleiros haviam me calcado como ao pobre maninelo. (HERCULANO, 1959, p.466)

Percebe-se, assim, já nesse ponto, uma perspectiva diferente de $O$ Bobo, mas principalmente de Eurico, no que se refere à figuração do mouro. Além do contexto histórico não contemplar a época da invasão árabe, coloca-se, já no início da narrativa, uma correspondência entre o protagonista e os mouros. Primeiramente pelo narrador, 
que chama atenção para herança moura presente em sua constituição e depois pelo próprio Vasco, que se compadece e identifica-se com o truão Alé, pela situação opressora vivenciada por ambos.

E, o que ocorre a seguir reforça a afinidade, aí indiciada: Vasco fica sabendo que um dos cavaleiros que iniciou as agressões ao truão era Lopo Mendes, aquele que havia lhe tomado, de forma desonrosa, a noiva. Quando Vasco encaminha uma carta a Lopo, convocando-o para um duelo, ele recebe como resposta o seguinte bilhete: "Quem quer que sejas, vilão, põe aí o teu nome, para que te faça açoitar como a um mouro perro e fugidiço." (HERCULANO, 1959, p.466). Mais uma vez a identificação de Vasco com um mouro é reforçada, agora, pela carta afrontosa enviada por Lopo, que utiliza a expressão "mouro perro e fugidiço" para comunicar o absoluto desprezo sentido pelo cavaleiro que o desafiara para o duelo. Embora o termo seja usado para expressar um xingamento, o autor da afronta é um dos antagonistas da trama, o que desautoriza, em parte, o insulto.

Mas, parece ainda mais significativo para se perceber a forma como Herculano situa o mouro nesse contexto histórico, referente à sociedade portuguesa da época de D. João I, o que ocorre em dois excertos consecutivos da narrativa. O primeiro, quando o mouro, Alé, procura Fr. Lourenço para que este ouça a confissão de Beatriz. Na sua ausência, Alé é recebido por Fr. Julião, o porteiro que, tratando sempre o visitante de modo sarcástico, despede-se dele da seguinte forma: "Dize a quem te mandou que confie na nossa caridade. E tu vai-te com Alá... (que é o Diabo: acrescentou Fr. Julião em voz baixa, e benzendo-se - assim Deus me perdoe...)." (HERCULANO, 1959, p.477). Aqui, evidencia-se uma concepção bastante comum nas lendas referentes aos mouros, na qual se associam características diabólicas ao 
Islamismo.

Como dizíamos, outro excerto, aí justaposto, complementa, de forma significativa, a perspectivação da presença moura nesse contexto. Agora, em um discurso com fundo claramente factual e historiográfico, o narrador disserta sobre a pacífica convivência entre mouros, cristãos e judeus nessa época. Tomando como mote o fato do visitante mouro habitar a aldeia do Restêlo, elabora-se um animado discurso exaltando a pacífica convivência entre esses três povos, na Península Ibérica do final do século XIV:

\begin{abstract}
A aldeia do Restêlo, situada a uma légua de Lisboa, [...] era no XIV século habitada em grande parte por mouros forros que nos arredores granjeavam algumas hortas e pomares [...] ou por pescadores que daí saiam em seus batéis a pescar no Tejo. Grande parte destes pescadores eram também mouros, ou livres ou escravos. Restêlo, como quase todas as aldeias das cercanias de Lisboa, ainda quase que parecia uma terra muçulmana no fim do século XIV; ainda então avultava entre a raça goda e a cristã a raça africano-árabe. Até esta época, ou antes até quase o fim do século seguinte, as Espanhas ofereciam um fenômeno único, talvez, na história: o de três povos, sectários de três religiões inimigas, vivendo juntos e cada qual adorando Deus a seu modo, sem que por isso viessem às mãos, apesar de todas essas crenças serem persuasões profundas e por conseqüência exclusivas. As três religiões eram o Cristianismo, o Islamismo e o Judaísmo: o primeiro dominante, o segundo tolerado e o terceiro consentido. Nobres, cavaleiros e o grosso dos burgueses pertenciam ao primeiro, os homens de trabalho, em boa parte, ao segundo, os mercadores, em grande número, ao terceiro. E acima do Evangelho e da Tora e do Alcorão, havia um livro que fazia o que nunca souberam fazer os comentadores de cada um deles; um livro que os conciliava. Este livro era a lei. A lei protegia os diversos cultos nacionais, sem que, todavia, compreendesse inteiramente a tolerância como nós hoje a compreendemos. (HERCULANO, 1959, p.478)
\end{abstract}

Depois dessa longa digressão o narrador retoma, em uma transição abrupta, o contexto referente à viagem ao Restêlo dos dois monges: "Desta tolerância político religiosa era prova o que sucedia em Restêlo quando Fr. Lourenço e Fr. Vasco aí chegaram.” (HERCULANO, 1959, p.478). A justaposição dos trechos tão díspares, um 
de caráter histórico, resguardando-se evidentemente o componente ficcional aí admitido, bastante longo e descritivo, outro propriamente fictício, constituinte do desencadeamento narrativo, conciso e direto, causa algum estranhamento. A estrutura faz pensar o papel da história e da ficção na obra de Herculano e em como seria constituída a relação de causalidade entre essas componentes.

As duas situações consecutivas, destacadas na narrativa, poderiam representar um paradigma seguido ao longo de todo o texto: por um lado, o narrador, muitas vezes assemelhado ao historiador Herculano, exalta a pacífica convivência dos mouros com os cristãos e judeus, por outro, a ação dos personagens explicita a atmosfera de intrigas e preconceitos reinante entre esse povos. O que pode parecer contraditório, entretanto, torna-se coerente na seguinte tentativa de síntese feita pelo narrador:

Todavia não se creia que os legisladores ou o povo eram tíbios na fé. Como religionário, o cristão detestava ou antes desprezava o mouro e o judeu; como cidadão, vivia e tratava com ele. Nas leis relativas a essas duas raças réprobas não há uma só palavra que revele hesitação ou indiferença religiosa; mas vê-se que à sua promulgação presidiu a sabedoria. $\mathrm{O}$ fanatismo cego, bruto e feroz veio-nos com as primeiras luzes de uma falsa civilização, nos fins do século $\mathrm{XV}$, e progrediu com ela por todo o XVI. Dantes a raça cristã tinha a consciência de uma grande superioridade religiosa e fazia-a valer na legislação; mas não confundia a crueldade com as distinções que nascem da diferença entre o superior e o inferior. (HERCULANO, 1959, p.478)

Enfim, há, sem dúvida, um elogio dos aspectos legislativos que promovem e viabilizam a tolerância entre os cidadãos judeus, cristãos e muçulmanos. Mas, outro fato inequívoco aí colocado é a prevalência do desprezo e ódio dos cristãos pelos seguidores dessas outras religiões. As últimas frases parecem revelar a crença do próprio narrador na superioridade do que ele chama de "raça cristã". Destacamos, abaixo, outro segmento desse texto, no qual o narrador, valendo-se de argumentos retirados de fatos 
historiográficos, questiona as motivações que levariam os legisladores a concederem tais benefícios aos seguidores do Islamismo.

\begin{abstract}
Nenhuma admiração deve, talvez, causar esta proteção relativamente ao Judaísmo; porque a favor desta crença falavam as riquezas dos seus sectários; mas o que em verdade espanta é a tolerância, quase diríamos o favor, que achava no ânimo dos legisladores o Islamismo. A maioria dos mouros era escrava e pobre, e além disso, eles tinham sido, havia apenas dois séculos, inimigos armados, adversários duros e senhores das terras que ora cultivavam servos. Ainda, além disso, um reino mourisco subsistia em Espanha - Granada - Granada, mãe de valentes soldados e donde podia partir o raio que derribasse mais de uma cruz levantada sobre mesquita convertida em catedral; e todavia estes homens achavam amparo nas leis dos seus vencedores. Por algumas destas leis, feitas na primeira metade do século XV, chegaram a ficar sujeitos a graves penas aqueles que ousavam ofender esses desgraçados na única herança que lhes restava, a religião de seus pais. (HERCULANO, 1959, p.478)
\end{abstract}

Ainda que sem condições de verificar os fatos históricos que poderiam subsidiar o relato acima, por não ser esse o objetivo da tese e pela dificuldade que os próprios historiadores encontram em retratar a presença moura em Portugal nesse período, podemos, entretanto, aventar algumas significações concluídas da própria elaboração narrativa. Nota-se que a permanência e a aceitação dos mouros em Portugal são explicadas unicamente como um favor dos legisladores católicos sem se considerar o que nos parece um fato irrefutável: a necessidade ainda que seja da mão de obra desses povos. A ausência de explicação lógica para o fato induziria a uma justificativa pautada apenas pela condescendência dos legisladores e, por conseguinte, do Cristianismo em relação aos mouros.

Mas, poderíamos antever também, nesse trecho, o que parece ser uma angústia legítima do historiador Herculano, aqui atuando como narrador, pela impossibilidade de conjugar de forma silogística os dados históricos recolhidos. De fato, o autor confessa na nota posposta à narrativa de $O$ Monge a dificuldade em elaborar a 
extensa pesquisa documental e as contradições factuais aí encontradas:

Perder a paciência e a vista sobre os gastos e difíceis caracteres dos documentos; devorar páginas insulsas e não raro inúteis, de bacamartões pesados; aforoar crônicas; ter de apurar muitas vezes de centenares de sucessos contraditórios, e na aparência indiferentes, os sucessos capitais da história [...] (HERCULANO, 1959, p.478)

Seja pela abundância documental, muitas vezes contendo fatos incongruentes, seja pela extensão da própria obra narrativa que, como vimos, abarca situações aparentemente independentes, que não se conformam bem em uma unidade, ou ainda, pela distância temporal entre os dois momentos de elaboração da obra, 1839/1840 e 1847/1848, algumas discordâncias factuais são realmente percebidas no interior da narrativa.

António Dias Farinha ressalta, por exemplo, uma contradição encontrada na descrição dos mouros, situada logo no início do texto. O pesquisador confronta o seguinte trecho da obra, "A maioria dos mouros era escrava e pobre [...]" (HERCULANO, 1959, p.477), com outro, colocado pouco a frente, relativo às celebrações e festas mouriscas e judaicas, nas quais se podia apreciar a situação abastada desses povos: “[...] da maior abastança em que mouros e judeus viviam, por serem, regularmente falando, mais sóbrios, laboriosos e econômicos que eles, bons discípulos do Evangelho." (HERCULANO, 1959, p.479). Farinha destaca a divergência referente à situação de pobreza dos mouros no primeiro fragmento e o privilégio econômico desses povos no segundo. O autor acrescenta ainda que tal disparidade refletiria a própria ambiguidade presente em Alexandre Herculano, ao desempenhar o papel de escritor e de historiador.

Farinha apresenta ainda uma posição que, embora corrobore outras opiniões sobre o assunto, nos parece um pouco problemática. Referimo-nos àquela distinção, já 
mencionada, entre uma postura mais correta de Herculano em sua obra historiográfica em oposição ao viés tendencioso da obra literária. Sobre isso, Farinha diz o seguinte:

\begin{abstract}
A impressão colhida por Herculano (historiador) sobre o impacto da presença árabe na Península Ibérica é de geral harmonia entre os novos conquistadores e a população dominada. Parece-nos, no entanto, que as opiniões de Herculano-historiador e de Herculanonovelista divergem curiosamente e situam-se no centro do debate que não podemos iludir acerca dos componentes culturais na nação portuguesa. (FARINHA, 1977, p.332).
\end{abstract}

Como se pode notar, a situação descrita acima refere-se à época do domínio árabe em Portugal, bem anterior, portanto, ao XIV século abordado em $O$ Monge de Cister. Mas esse contraste apontado entre o Herculano historiador e o ficcionista serve ainda ao pesquisador como argumento para tentar explicar aquela contradição referente à figuração dos mouros apontada nessa obra anteriormente. E, a justificativa de António Dias Farinha para a cisão sofrida no conjunto da obra de Alexandre Herculano é a seguinte:

O escritor de ficção histórica deixou conduzir-se pela religiosidade pessoal integrada no Cristianismo numa época (meados do século $\mathrm{XIX)} \mathrm{em} \mathrm{que} \mathrm{as} \mathrm{barreiras} \mathrm{entre} \mathrm{as} \mathrm{duas} \mathrm{religiões} \mathrm{eram} \mathrm{ainda} \mathrm{imensas} \mathrm{e}$ pela necessidade de criar um quadro de dramatismo intenso que assegurasse o interesse pelo desenrolar da ação. (FARINHA, 1977, p.334)

Entendemos, todavia, que o que conduz não apenas Farinha, mas diversos outros críticos da obra de Herculano, a esse ponto de vista, que nos parece equivocado, é o fato de tomarem uma leitura reducionista de Eurico como paradigma para se pensar o conjunto da obra literária do autor. Conforme já foi enfatizado no tópico anterior, referente a $O$ Bobo, e também agora na análise de $O$ Monge de Cister, há uma especificidade não apenas temática, mas, também, estilística em cada uma dessas obras, 
o que determina, consequentemente, figurações diversas do elemento mouro em cada um dos textos. Assim, apesar de nos abstermos de analisar a obra historiográfica de Alexandre Herculano, podemos dizer que a bibliografia especificamente literária do autor é bastante variável no que se refere à figuração do mouro e, portanto, não é possível tomá-la como um parâmetro de comparação homogêneo e regular.

De qualquer forma, é importante ressaltar que António Dias Farinha percebe em $O$ Monge de Cister, uma obra que traz referências significativas à presença moura em Portugal, fazendo alusões à ambientação, aos costumes e cultura árabes presentes no romance. O pesquisador, entretanto, não se ocupa do tratamento individual dos personagens, deixando ainda de mencionar fatos importantes da trama narrativa, o que, a nosso ver, conduziria a uma perspectiva bem mais reveladora da forma como Herculano retratou o mouro em sua obra ficcional.

Uma das personagens mouras apresentada na obra, por exemplo, tem uma contribuição apenas acessória para a trama narrativa. A figuração de Zilá, a filha de Muça, entretanto, é bastante interessante, na medida em que poderia representar reminiscências das lendas referentes às mouras encantadas. Sua principal representação se dá no Capítulo IV, intitulado "A Festa da Maia”, no qual é retratada uma comemoração popular, de origem pagã, das maias, em homenagem à chegada da primavera, realizada, nesse caso, pela comunidade mourisca da Aldeia do Restêlo, onde, de fato, habitavam muitos "[...] mouros forros que nos arredores grangeavam algumas hortas e pomares, de que ajudavam a abastecer a cidade, ou por pescadores que daí saíam em seus batéis a pescar no Tejo.” (HERCULANO, 1959, p.477).

Zilá, adornada de flores, fazia o papel principal na comemoração popular. Inicialmente, a moura é destacada por sua beleza e elegância, despertando grande 
incômodo em tia Domingas e Marta. As duas beatas referem-se a ela como, "negregada cadela" e "perra" (HERCULANO, 1959, 479). Sabe-se, entretanto, logo a seguir, que tia Domingas tivera um passado bastante obscuro, no qual figuraria uma longa relação com um clérigo.

A moura Zilá passa a ser vista não apenas como vítima da maledicência das beatas, mas também do assédio de Rui Casco. E o narrador, que antes se referia a ela como "uma sultana" que naquele momento "não trocaria [...] a sua glória pela sorte da esposa querida do profeta" (HERCULANO, 1959, 481), apresenta, então, de forma metafórica, o sofrimento do qual padecia Zilá por ter sido vendida a Rui Casco sendo obrigada, então, a submeter-se a ele:

Mas a filha de Muça era apenas uma planta de oásis açoitada pelo sopro do Simum. Em um dia sereno erguia a fronte, como quando pura vicejava no princípio do existir. Mas a seiva da vida estava contaminada: o bafo impudico do homem é também como o Simum. Flor de inocência por onde ele passou não erguerá a fronte mais que um dia. Depois vem logo o pender e o murchar. Há aí então alguém cujos olhos ela contente? Não. Só o vento do deserto virá ainda uma e outra vez afagá-la com abraço infernal, até que lhe disperse a última folhinha, como o algoz espalha ao longe o último punhado das cinzas de um justiçado. A flor que ainda erguia a fronte era Zilá, a maia do Restêlo; mas Rui Casco era o Simum do deserto. (HERCULANO, $1959,481)$

Em um trecho posterior, quando é retratada a Procissão de Corpus, na qual tia Domingas tentaria, inutilmente, executar o plano traçado por Vasco, a beata é surpreendida por Rui Casco que procura desesperadamente Zilá. Nesse excerto fica mais evidente a grande atração que Zilá exercia sobre o almuinheiro, presentificando-se pela voz do próprio narrador o espelhamento entre a filha de Muça e as mouras lendárias: “[...] Rui, a quem a esperança de descobrir a sua moura encantada varrera da memória a procissão, a almuinha e a multa municipal [...]" (HERCULANO, 1959, 
p.595).

$\mathrm{Na}$ maioria das lendas de mouras encantadas, essas figuras mitológicas exercem uma atração irresistível sobre os homens, muitas das vezes cristãos, mas em algumas narrativas também elas são submetidas e escravizadas por seus amantes. Em Zilá podemos perceber a conjunção das duas situações, mas, sem dúvida, ocorre uma ênfase no sofrimento da moura que ainda muito jovem foi vendida a um cristão, Rui Casco, perdendo assim sua liberdade e juventude.

Conforme já abordado parcialmente, o personagem mouro, Alé, por exemplo, tem uma participação bem mais significativa na trama de $O$ Monge de Cister. Como foi visto, ele funciona em uma ocasião específica, inclusive, como um parâmetro para o espelhamento do protagonista, acentuando, assim, o componente mouro referenciado no perfil de Vasco. Além disso, é Alé quem encontra e salva Beatriz, quando ela é abandonada por Fernando Afonso.

Da mesma forma que o truão, D. Bibas, entretanto, o caráter de Alé é pouco preciso. As ações dele em relação à irmã de Vasco são, de fato, benéficas e irrepreensíveis, mas, pelo modo como isso é apresentado na narrativa, parece ter sido, exatamente, o sentimento do mouro por Beatriz que desencadeou no truão a tomada de uma conduta mais apropriada moralmente. Por outro lado, o impulso inicial de compaixão e solidariedade do mouro em relação à irmã de Vasco é atribuído, de fato, aos próprios preceitos do islamismo, como se pode acompanhar, abaixo, no excerto que contém a explicação de Alé a Fr. Lourenço sobre tal evento:

A minha lei, Padre cristão, obriga-me a socorrer o desventurado: obedeci à lei. [...] Pensei então que corria grande risco em a [Beatriz] conservar em casa: mas também pensei no que reza o livro do Profeta, e disse comigo: - Que importa no mundo a vida de um pobre truão, quando há que escolher entre essa vida e obedecer a Alá? (HERCULANO, 1959, p.485) 
A resposta de Fr. Lourenço, personagem absolutamente íntegra e confiável, representa, em certa medida, determinada perspectiva presente ao longo da narrativa, no que se refere à figuração dos mouros. Ele diz o seguinte: "Amaste Deus e o teu próximo: foste mais cristão que a maior parte dos que se gloriam de tal nome. Caridade, e só caridade é a crença de Jesus. Ele te alumiará; porque deste testemunho dele, não por palavras, mas por obra." (HERCULANO, 1959, p.485). Entre os diversos sentidos implicados nessa fala, há uma expressão condescendente, que anula a religiosidade de Alé, e percebe, entretanto, a sua revelia, valores e atitudes cristãos. Da mesma forma que os pecadilhos do povo aparentam ser perdoados pelo narrador, também o mouro Alé, ignorante e ingênuo, como o restante do povo, é também ressalvado por Fr. Lourenço. Posteriormente, quando o truão começa a ser manipulado por D. João d'Ornelas e passa, também, a agir em função de uma vingança pessoal contra Fernando Afonso, tal perspectiva parece tornar-se ainda mais evidente.

Assim, embora seja claramente importante a ação heróica inicial do mouro e, ainda mais significante que isso, a atribuição de sua atitude aos princípios propostos pela religião muçulmana, parece ocorrer um apagamento de sua dimensão religiosa islâmica em favor da sua condição popular e truanesca. De fato, a ênfase aparenta recair mais no cotidiano popularesco de Alé e na sua participação como truão da corte de D. João I do que nas especificidades étnica e religiosa que poderiam definir sua condição moura. E, nessa situação, assim como ocorre com o grupo popular no qual é diluído, o truão mouro é representado de forma ambígua, com uma caracterização moral flexível, mas prevalecendo, afinal, uma perspectiva narrativa positiva e complacente em ralação a ele. 


\section{III.2 - Lendas e Narrativas}

\section{III.2.1 - Introdução}

Em 1851, Alexandre Herculano reuniu, em volume, diversos textos literários publicados entre os anos de 1838 e 1846, nas revistas O Panorama e $A$ Ilustração, intitulando a coletânea de Lendas e Narrativas. A maioria dos textos foi escrita anteriormente a Eurico, o presbitero, O Monge de Cister e O Bobo. Ofélia Paiva Monteiro, como outros autores, diz que esses “contos e novelas históricos representaram para o escritor uma preparação para os seus romances" (MONTEIRO, s.d., p.27). O próprio Herculano, na "Advertência da primeira edição" de suas Lendas, diz que o mérito de tais textos e a razão da publicação em volume é, justamente, por se encontrar aí o marco inicial da romance histórico português:

Corrigindo-os e publicando-os de novo, para se ajuntarem a composições mais extensas e menos imperfeitas que já viram a luz pública em volumes separados, ele [o próprio Herculano] quis apenas preservar do esquecimento, a que por via de regra são condenados, mais cedo ou mais tarde, os escritos inseridos nas colunas das publicações periódicas, as primeiras tentativas do romance histórico que se fizeram na língua portuguesa. (HERCULANO, s.d., p.VI)

E, de fato, à exceção de $O$ Pároco da Aldeia e do texto autobiográfico De Jersey a Grandville, encontramos nessas narrativas a prevalência da ambientação medieval, assim como, recortes de importantes fatos e lendas da história nacional.

Entre 1838 e 1839, Herculano publicou, na imprensa periódica, "O Castelo de Faria”, “O Bispo Negro”, e “A Abóbada”, posteriormente, de 1841 a 1842, o autor lançou, também aí, "Arras por Foro de Espanha". "A Dama Pé-de-Cabra” saiu no 
Panorama em 1843, e, finalmente, foi publicado “O Alcaide de Santarém”, entre 1845 e 1846 (CARDOSO, 2003, p.168). Mas, esses contos representam uma seleção feita inicialmente, ao que tudo indica, pelo próprio Herculano, ficando outras narrativas do mesmo período e de anos anteriores, fora dessa primeira publicação em volume. A maioria dos contos, inclusive, constava nas páginas de $O$ Panorama sem assinatura "dado o anonimato inicial da colaboração [de Herculano] dada à revista." (CARDOSO, 2003, p.168).

Margarida Cardoso levanta duas hipóteses para a exclusão de algumas narrativas em tal seleção realizada por Herculano: "ou porque o Escritor os julgasse esteticamente fracos, ou porque quisesse deixar cair no esquecimento textos "reinvestidos" em obras de maior vulto (é o caso de "Destruição de Áuria”, que parece representar um avatar incipiente de Eurico)" (CARDOSO, 2003, p.168).

Os contos apresentados nas Lendas e Narrativas são considerados por diversos críticos como um trabalho, sobretudo, de pesquisa e recolha de lendas tradicionais, apresentando uma menor elaboração ficcional do que os romances ou novelas. Margarida Cardoso, por exemplo, faz o seguinte comentário sobre a questão:

[...]são textos breves, em que a articulação da "tradição" ou da "verdade" com a ficção - difícil escolha da novela histórica - se faz com menos ousadia do que nos romances; limitam-se, com efeito, a dramatizar, com maior ou menor trabalho ficcional, relatos de nosso passado colhidos em obras antigas [...] (CARDOSO, 2003, p.169)

Ofélia Paiva Monteiro tece uma reflexão bastante semelhante sobre o assunto, ela diz que "nesses textos curtos, Herculano quase se limita, por vezes, à dramatização de relatos do nosso passado colhidos em obras antigas" (MONTEIRO, s.d., p.27). Percepção que se alinha ainda com a de Maria de Fátima Marinho ao dizer: “[...] os textos de Lendas e Narrativas [...], na sua maioria, são quase a transcrição de 
capítulos das crônicas medievais." (MARINHO, 1999, p.54). O problema de qualquer tentativa de apreciação geral da obra reside no fato de ela constituir-se de forma heterogênea, a partir de contos que abarcam diversidades temáticas e estéticas, e cuja extensão varia da forma breve até textos bastante longos, comparáveis, neste quesito, a O Bobo ou Eurico.

Na edição das Obras Completas do escritor, publicada em 1970, pela Bertrand, tentou-se, inclusive, constituir outra disposição que organizasse de modo mais coerente e homogênea as Lendas e Narrativas. Assim, o texto de temática contemporânea, "O Pároco de Aldeia”, passou a fazer parte de um volume autônomo acrescido de outra novela, "O Galego", que havia sido publicada apenas nas páginas de A Ilustração. Suprimiu-se também do volume referente às Lendas e Narrativas o texto de cunho autobiográfico, "De Jersey a Grandville", que foi anexado ao volume Cenas de Um Ano da Minha Vida.

Assim, na nova edição das Lendas e Narrativas, "permaneceram as ficções 'históricas' e a novela fantástica, acrescidas de textos ficcionais de índole idêntica recuperados dos que o escritor, sem a assinatura ou só com as iniciais de seu nome, publicara n'O Panorama" (MONTEIRO, s.d., p.26), Os textos acrescidos são: "Destruição de Áuria”, “O Emprazado", "O Mestre Assassinado”, "Mestre Gil”, "Três Meses em Calecut", "O Cronista" e "Os Sete Dormentes". Lembramos que, da configuração original da obra, permaneceram ainda as seguintes narrativas: "O Alcaide de Santarém", “Arras por foro d'Espanha”, “A Abóbada”, “A Dama Pé-de-Cabra”, "O Bispo Negro" e “A Morte do Lidador".

Comentaremos a seguir, brevemente, alguns contos que contêm referências relevantes aos mouros, considerando aspectos mais relevantes inerentes ao enredo, e 
também à trajetória editorial, da publicação em periódico à apresentação em volume. Analisaremos com maior acuidade a narrativa "O Alcaide de Santarém", justamente, por se apresentar, aí, com maior ênfase, a temática da presença moura na Península Ibérica.

\section{III.2.2 - O Bispo Negro}

"O Bispo Negro" seria parte de um conto, publicado em 1839, no Panorama, denominado "O Cronista", cujo primeiro plano da ação se passa em 1535 , estabelecendo "um paralelo entre a subserviência de D. João III ao poder de Roma, traduzido pelo estabelecimento da Inquisição, e a independência antiga ante o Papado, testemunhada pela história do "bispo negro" sob o reinado do jovem Afonso Henriques." (CARDOSO, 2003, p.170). E, conforme explica Margarida Cardoso, Herculano no volume das Lendas e Narrativas isolou parte desse texto "sob o título "O Bispo Negro", introduzindo-lhe algumas modificações." (CARDOSO, 2003, p.170)

Já a narrativa de "O Bispo Negro" retrata, especificamente, o ano 1130, época do reinado de Afonso Henriques. A lenda aí elaborada aborda, de maneira geral, os seguintes fatos:

Afonso Henriques prende a mãe no castelo de Lanhoso. O bispo de Coimbra intima o príncipe, sob pena de excomunhão, a soltá-la. Não só não lhe obedece o jovem Rei, como o expulsa da diocese, nomeando para o bispado o clérigo negro de Soleima. (BARREIROS, 1989, p.83)

No final do conto é apresentada uma nota explicativa que esclarece a origem fantasiosa de tal lenda. O texto teria sido extraído das "crônicas de Acenheiro, rol de 
mentiras e disparates publicado pela nossa Academia [...]" (HERCULANO, 19--, p.76). De qualquer forma, encontram-se, no conto de Herculano, apenas, algumas breves alusões às lutas contra os mouros como, por exemplo, no seguinte excerto:

Em uma das torres do velho alcácer de Coimbra, assentado entre duas ameias, a horas em que o sol fugia do horizonte, o príncipe conversava com Lourenço Viegas, o Espadeiro, e com ele dispunha e apurava traças para guerrear a mourisma. (HERCULANO, 19--, p.58 - 59).

Podem, ainda, ser verificadas outras poucas menções, também despretensiosas, referentes às lutas com os mouros que permaneciam nas fronteiras do reino. Mas, uma referência mais importante se apresenta bem no início da narrativa, já nos primeiros parágrafos, quando se descreve a Catedral de Coimbra, cenário principal da ação narrativa:

Então aquelas ameias e torres não haviam sido tocadas das mãos de homens, desde que seus edificadores as tinham colocado sobre as alturas; e, todavia, já então ninguém sabia se esses edificadores eram da nobre raça goda, se da dos nobres conquistadores árabes. Mas, quer filha dos valentes do norte, quer dos pugnacíssimos sarracenos, ela era formosa, na sua grandeza, entre as outras sés da Espanha. Aí sucedeu o que ora ouvireis contar. (HERCULANO, 19--, p.57 - 58)

Verifica-se assim que, enquanto o foco da narrativa volta-se para um conflito específico entre Afonso Henriques e o Papa, fazem-se, em um plano secundário, algumas alusões à presença dos árabes em Portugal. Em uma delas ressaltase a herança arquitetônica deixada por eles, referindo-os, não como invasores, mas como "nobres conquistadores". Outras abordam as condições cotidianas da região, e referem-se à necessidade constante de guardar as fronteiras dos mouros invasores, chamados em alguns momentos de infiéis. Não é possível, entretanto, estabelecer pela terminologia utilizada uma diferenciação valorativa entre os povos denominados árabes 
e mouros. Como já foi atentado anteriormente, também neste conto, Herculano utiliza as diversas nomenclaturas indistintamente.

O que, de fato, poderia ser considerado como parâmetro diferenciador entre uma perspectiva negativa e outra positiva, e até mesmo elogiosa, em relação aos mouros seria apenas o momento histórico no qual estariam localizados. Quando o narrador aborda a presença remota desses povos na península há uma positivação de sua representação pela herança arquitetônica deixada, como visto na citação anterior, ou na breve menção ao palácio de Coimbra: "Em uma das salas mouriscas dos nobres paços de Coimbra havia grande sarau." (HERCULANO, 19--, p.66). Por outro lado, como já foi apontado, a realidade presente delineia, em seu plano de fundo, a ameaça constante dos mouros, que se encontram nas fronteiras do reino e contra os quais é preciso lutar, como se pode acompanhar, também, nas seguintes palavras, carregadas de ironia, que Afonso Henriques dirige ao Cardeal: “[...] creio me trazeis agora algum ouro, que de seus grandes haveres me manda o senhor papa para estas hostes que faço e com que guerreio, noite e dia, os infiéis da frontaria.” (HERCULANO, 19--, p.69)

\section{III.2.3 - A morte do Lidador}

Tanto “O Bispo Negro", ambientado em 1130, como "A morte do Lidador", em 1170, apresentam contextos subsequentes àquele retratado em $O$ Bobo, apresentando, inclusive, personagens históricos em comum, como Afonso Henriques, figura central também de "O Bispo Negro", e Gonçalo Mendes da Maia, que protagoniza "A morte do Lidador". Este conto, conforme indicado no título, retrata o 
último dia de vida do Lidador. Na data em que comemora os noventa e cinco anos de seu nascimento, ele decide realizar, juntamente com seus amigos, uma celebração, cujo objetivo é lutar contra os mouros fronteiriços. Assim, inicia-se a narrativa pela voz do próprio protagonista:

Senhores cavaleiros, hoje contam-se noventa e cinco anos que recebi o batismo, oitenta que visto armas, setenta que sou cavaleiro, e quero celebrar tal dia fazendo uma entrada por terras da frontaria dos mouros. (HERCULANO, 19--, p.81)

Sabe-se, pela narrativa, que, tempos atrás, Gonçalo Mendes da Maia fora nomeado por Afonso Henriques fronteiro da cidade de Beja. E, nesse contexto, são apresentadas algumas referências à ocupação moura na região do Alentejo, ocorrida anteriormente, e à necessidade de ainda se protegerem as fronteiras dos invasores, conforme exposto a seguir:

Nesta luta de vinte gerações andavam lidando gentes do Alentejo. O servo mouro olhava todos os dias para o horizonte, onde se enxergavam as serranias do Algarve: de lá esperava ele salvação ou, ao menos, vingança; ao menos, um dia de combate e corpos de cristãos estirados na veiga para pastos de açores bravios. [...] E este ameno dia de julho devia ser um desses dias por suspirava o servo ismaelita. (HERCULANO, 19--, p.85)

Dessa reflexão passa-se diretamente à descrição das ações de Almoleimar, um chefe mouro que se encontrava nas cercanias de Beja, e do lidador, que juntara uma comitiva de trinta cavaleiros com intento de duelar contra os infiéis das fronteiras. Assim, à medida em que o grupo liderado por Almoleimar se aproximava da fronteira em direção à Beja, Gonçalo Mendes da Maia e seus seguidores dirigiam-se do interior da cidade para um ponto comum, conforme justaposto no mesmo parágrafo: "Almoleimar descera com os seus cavaleiros às campinas de Beja. [...] Ao romper 
d'alva, os cavaleiros do Lidador saíam a mais de dois tiros de besta além das muralhas de Beja.” (HERCULANO, 19--, p.85). Compondo-se, desse modo, de forma alternada, as ações dos dois opositores, um cristão outro muçulmano, a narrativa vai constituindo uma atmosfera de expectativa em relação ao provável confronto.

O encontro entre os dois grupos é descrito a partir de uma assimetria numérica, que destaca a situação privilegiada dos mouros já no início do conflito. Comparam-se, também, as armas dos cristãos e dos muçulmanos, destacando-se aí a oposição entre a força rude dos portugueses, extraída de sua ascendência gótico-romana, e a engenhosidade mais refinada dos árabes:

Enfileirados em extensa linha, os cavaleiros árabes saíram à rédea solta de trás da escura selva que os encobria: o seu número excedia cinco vezes o dos soldados da cruz; as suas armaduras lisas e polidas contrastavam com a rudeza dos cristãos, apenas defendidos por pesadas cervilheiras de ferro e por grossas cotas de malha do mesmo metal; as lanças destes eram mais robustas, e as suas espadas mais volumosas do que as cimitarras mouriscas. A rudeza e a força da raça gótico-romana iam, ainda mais uma vez, provar-se com a destreza e com a perícia árabes. (HERCULANO, 19--, p.89)

É curioso que logo no seguinte parágrafo, retoma-se a descrição da mesma cena, mas considerando-se, agora, o quadro geral de combatentes, apresentando-se, nesse ponto, o elogio absoluto dos portugueses, sem nenhuma ressalva à valentia árabe. A desproporção entre os mouros e os portugueses torna-se, aí, ainda mais discrepante, contando-se apenas um soldado cristão para cada dez mouros, conforme o seguinte excerto: 
Quem visse aquele punhado de cristãos diante da cópia de infiéis que os esperavam, diria que não com brios de cavaleiros, mas com fervor de mártires, se ofereciam a desesperado trance. Porém não pensava assim Almoleimar, nem os seus soldados, que bem conheciam a têmpera das espadas e lanças portuguesas e a rijeza dos braços que as meneavam. De um contra dez devia ser o inimigo combate; mas se havia ali algum coração que batesse descompassado, algumas faces descoradas, não era entre os companheiros do Lidador que tal coração batia ou que tais faces descoravam. (HERCULANO, 19--, p.90)

O procedimento presente na narrativa, ao descrever de forma desproporcional a luta entre cristãos e mouros, privilegiando a valentia e coragem dos primeiros que conseguem vencer o exército muçulmano mesmo em grande desvantagem numérica, mimetiza um padrão recorrente nas lendas populares relativas ao assunto. Alexandre Parafita depreende da análise de um corpus bastante significativo de lendas com tema referente às disputas entre cristãos e mouros as seguintes constatações:

Não menos significativo é o sucesso bélico dos cristãos, em situações de correlação de forças radicalmente anômala. Na verdade, no confronto entre as duas etnias/religiões, o corpus apresenta-nos diversos exemplos de minúsculos exércitos cristãos que alcançam vitórias arrasadoras e decisivas sobre os mouros. (PARAFITA, 2006, p.69)

Mas, retomando a narrativa herculaniana, acompanha-se, a seguir, o duelo entre Gonçalo Mendes da Maia e Almoleimar. E, depois da descrição bastante detalhada do violento embate ocorrido, o Lidador acaba por vencer o mouro:

As espadas reluziram no ar; mas o golpe do Lidador era simulado, e o ferro, mudando de movimento no ar, foi bater de ponta no gorjal de Almoleimar, que cedeu à violenta estocada; e o sangue saindo às golfadas, cortou a última maldição do agareno. (HERCULANO, 19--, p.93)

Continua-se, assim, a narração do combate com formas bastante distintas de apreciação das ações dos mouros, que estavam em grande vantagem numérica, e dos 
portugueses, muitíssimo mais corajosos e valentes, como se pode ter uma idéia no seguinte trecho: "Se os mouros, porém, levavam, fugindo, vergonha e dano, a vitória não saíra barata aos portugueses. Viam perigosamente ferido o seu capitão, e tinham perdido alguns cavaleiros de conta [...]" (HERCULANO, 19--, p.95). E, nesse contexto, surge, com o seu exército, a figura de Ali-Abu-Hassan, o rei de Tanger, para apoiar os combatentes muçulmanos.

O final da narrativa conta, ainda, com descrições do esforço sobre-humano de Gonçalo Mendes da Maia, que, embora gravemente ferido e à beira da morte, consegue combater muitos soldados mouros. Também sua morte é narrada de forma grandiosa, sendo desencadeada por um golpe que ele próprio impõe a um mouro e não, exatamente, pelo ataque de seus opositores:

Depois de deixar assinadas muitas armaduras mouriscas, o Lidador vibrara pela última vez a espada e abrira o elmo e o crânio de um cavaleiro árabe. $\mathrm{O}$ violento abalo que experimentou fez-lhe rebentar em torrentes o sangue da ferida que recebera das mãos de Almoleimar e, cerrando os olhos, caiu morto ao pé do Espadeiro e de Afonso Hermigues de Bayão, que com eles se juntara. Repousou, finalmente, Gonçalo Mendes da Maia de oitenta anos de combates! (HERCULANO, 19--, p.99)

E, como vingança à morte do Lidador, Lourenço Viegas consegue, ainda, matar o rei mouro, Ali-Abu-Hassan. Com essa perda, os mouros, embora fossem agora absurdamente mais numerosos que os portugueses - sessenta cristãos entre mais de mil muçulmanos -, acabaram por fugir do campo de combate, distanciando-se, finalmente, das terras portuguesas.

Em uma justificativa, um tanto irônica, para os fatos tão espantosos e improváveis apresentados no texto, o narrador faz a seguinte colocação: 
Quem hoje ouvir recontar os bravos golpes que no mês de julho de 1170 se deram na veiga da frontaria de Beja, notá-los-á de fábulas sonhadas; porque nós homens corruptos e enfraquecidos por ócios e prazeres de vida afeminada, medimos por nosso ânimo e forças as forças e o ânimo dos bons cavaleiros portugueses do século XII; e todavia esses golpes ainda soam, através das eras, nas tradições e crônicas, tanto cristãs como agarenas. (HERCULANO, 19--, p.99)

Se a explicação não parece, de fato, ter o intento de comprovar, muito seriamente, as inverossímeis peripécias apresentadas na narrativa, ela remete, entretanto, a uma concepção, geralmente atribuída à obra de Herculano, segundo a qual o passado heróico abordado na narrativa serviria de modelo para o presente em decadência. Sobre tal relação entre passado e presente, na obra herculaniana, Ana Cristina Correia Gil, na mesma linha de diversos outros críticos, declara o seguinte:

O romance histórico e a arte em geral estão, em Herculano, ao serviço da pedagogia da nação, pondo a nu a apatia e a decadência do tempo presente por comparação com o vigor e a glória passados. (GIL, 1999, p.78)

Os mouros assim retratados, como os inimigos da nação portuguesa e da religião cristã, assumem neste conto o papel de antagonistas, cujas ações são contempladas apenas na medida em que servem como contraponto para as atitudes heróicas dos portugueses. O próprio leitmotiv da trama já é bastante curioso: um duelo, entre portugueses e mouros, promovido como forma de celebração do aniversário do heróico fronteiro da cidade de Beja. De fato, parece haver aí um apagamento dos mouros, que, se não são considerados como combatentes corajosos, tendo em vista a desproporção dos exércitos, também não são retratados por designações negativas referentes a sua religião e costumes. Esse inimigo, quase abstrato, que já havia sido expulso, inclusive, da cidade de Beja, foi retomado, das fronteiras do Alentejo, como 
elemento antagônico essencial para se constituir uma lenda sobre os feitos heróicos dos portugueses e, entre eles, especialmente, da figura histórica e lendária de seu passado medieval, Gonçalo Mendes da Maia, o Lidador.

\section{III.2.4 - O Alcaide de Santarém (950 - 961)}

"O Alcaide de Santarém” foi publicado na imprensa periódica apenas em 1845-1846. Diversamente das outras narrativas de Herculano, neste conto, a presença dos mouros não se dá em relação aos portugueses ou espanhóis, mas em um contexto isolado, no qual importa apenas a própria sociedade constituída pelos invasores durante o seu domínio na Espanha. As referências aos cristãos ocorrem somente em breves alusões relativas às igrejas e aos moçárabes presentes na região, e à possibilidade de alguma disputa bélica. A trama se passa na região de Guadamelato e Córdoba. Logo no início da narrativa apresenta-se uma explicação referente à ocupação muçulmana nessas terras:

Desde o governo de Abul-Khatar o distrito de Córdoba fora distribuído às tribos árabes do Yemen e da Síria, as mais nobres e mais numerosas entre todas as raças da África e da Ásia que tinham vindo residir na Península, por ocasião da conquista ou depois dela. (HERCULANO, 19--, p.3)

Observa-se, já nesse ponto, que, na ausência dos opositores cristãos, faz-se necessário destacar entre os próprios muçulmanos o diferencial de nobreza - "as mais nobres e mais numerosas raças [...]" - dos personagens que serão retratados. Outra curiosidade deste conto, refere-se à restrição dos termos com os quais são referidos os muçulmanos. Aqui eles são nomeados apenas como árabes ou sarracenos, nunca como 
mouros.

Acompanha-se também, desde o início da narrativa, o esforço para se recriar um contexto que expresse fatos típicos da cultura e modo de vida árabe. É o caso, por exemplo, das referências aos hábitos nômades das famílias que se mudaram para a região e "conservaram por mais tempo os hábitos erradios dos povos pastores" (HERCULANO, 19--, p.4). Comenta-se, então, que, embora essas terras fossem bastante povoadas, pareciam, na verdade, um deserto:

[...] porque nem se descortinavam por aqueles cabeços e vales vestígios alguns de cultura, nem alvejava um único edifício no meio das colinas rasgadas irregularmente pelos algares das correntes ou cobertas de selvas bravias e escuras. (HERCULANO, 19--, p.4)

Constitui-se, assim, em tom poético, o aspecto ermo e selvagem da região. Mas, em um trecho justaposto, apresenta-se uma imagem ainda mais significativa do que essa, relativa aos cemitérios árabes:

Havia, contudo, povoações fixas naqueles ermos; havia habitações humanas, porém não de vivos. Os árabes colocavam os cemitérios nos lugares mais saudosos dessas solidões, nos pendores meridionais dos outeiros, onde o sol, ao pôr-se, estirasse de soslaio os seus últimos raios pelas lágeas lisas das campas, por entre os raminhos floridos das sarças açoitadas pelo vento. Era ali que, depois de vaguear incessante de muitos anos, eles vinham deitar-se mansamente uns ao pé dos outros, para dormirem o longo sono sacudido sobre as suas pálpebras das asas do anjo Azrael. (HERCULANO, 19--, p.4)

A aparente oposição estabelecida entre a escassez populacional da região e o excesso de "habitações humanas" do cemitério desencadeia, entretanto, a confluência entre as solidões sugeridas pelas duas imagens, potencializando a atmosfera erma da paisagem descrita. Identifica-se também, aí, um apelo ao exótico, expresso pela singularidade da ambientação inóspita e, principalmente, pela representação do 
nomadismo árabe, encerrado apenas com a morte serena junto ao anjo Azrael.

E, prosseguindo o assunto, o narrador tece uma reflexão também poética, ainda que com traços caricaturais, sobre a patente oposição entre a liberdade vivida pelos árabes e a morte, por eles representada, como um cativeiro:

A raça árabe, inquieta, vagabunda e livre, como nenhuma outra família humana, gostava de espalhar na terra aqueles padrões, mais ou menos suntuosos, do cativeiro e da imobilidade da morte, talvez para avivar mais o sentimento da sua independência ilimitada durante a vida. (HERCULANO, 19--, p.4)

Após a introdução mais reflexiva e lírica iniciam-se, de fato, as intrigas e ações que compõem a trama narrativa. De forma um tanto enleada, narra-se a vingança maquiavélica do faquir e profeta Al-ghafir, também chamado de Al-muulin, que significa "o triste". Ao longo do enredo, apresentam-se diversas inserções referentes aos costumes, cultura e arquitetura árabes, assim como, ao islamismo, como se pode verificar, por exemplo, na primeira caracterização de Al-ghafir: “A imaginação exaltada do povo tinha feito dele um santo, santo como o islamismo os concebia; isto é, como um homem cujas palavras e cujo aspecto gelavam de terror." (HERCULANO, 19--, p.18). Acompanham-se, também, várias descrições relativas à caracterização do espaço de Córdoba, cidade referida como a "suntuosa rival de Bagdá" (HERCULANO, 19--, p.16), com elementos diversos, entre os quais, árvores vindas da Pérsia e da Síria, almádenas, mesquitas, igrejas moçárabes, e banhos públicos.

Mas, como dissemos, para além da ambientação cuidadosamente constituída, o enredo contempla, também, uma trama de vingança e traição, que se inicia com a possibilidade de um novo califa assumir o trono de seu pai. Al-haken, filho mais velho de Abdu-r-rahman, assumiria o trono e seria assim o califa da Andaluzia e do Moghreb. E, sobre a festa de reconhecimento de Al-haken como herdeiro do 
califado, são feitos os seguintes comentários, nos quais destaca-se a riqueza cultural da Espanha sob o poderio árabe:

[...] o júbilo de Abdu-r-rahman havia se espraiado numa dessas festas, por assim dizer fabulosas, que só sabia dar no século décimo a corte mais polida da Europa, e talvez do mundo, a do soberano sarraceno de Espanha." (HERCULANO, 19--, p.16 - 17).

Mas, em uma visita ao rei Abdu-r-rahman, Al-ghafir, conhecido como o profeta Al-mulin, trava com o soberano um diálogo ardiloso, anunciando-lhe um grande sofrimento, e postergando, entretanto, a revelação dos fatos que irão ocorrer. A medida em que o faquir vai conduzindo astuciosamente as respostas dadas pelo rei, outros assuntos são também aludidos, como, por exemplo, o contexto histórico referente aos conflitos entre cristãos e muçulmanos e a maneira como os árabes encaram a al-djihed, ou Guerra Santa:

Os cristãos passaram a um tempo as fronteiras do norte e as do oriente. Meu velho tio Al-moddhafer já depôs a espada vitoriosa, e crês necessário expor a vida de um deles aos golpes dos infiéis. Vens profetizar-me a morte ao que partir. Não é isto? Faquir, creio em ti, que és aceito ao Senhor; mas ainda creio mais na estrela dos BenuUmeyas. Se eu amasse mais um do que outro, não hesitaria na escolha; fora esse que eu mandara não à morte, mas ao triunfo. Se, porém, essas são as tuas previsões, e elas têm de realizar-se, Deus é grande! Que melhor leito de morte posso eu desejar a meus filhos do que um campo de batalha, em al-djihed contra os infiéis? (HERCULANO, 19--, p.23)

Um pouco adiante, apresentam-se, também, referências ao papel do rei ou califa na sociedade muçulmana. Quando, em determinado momento, Al-ghafir chama Abdu-r-rahman de "iman da divina religião do koran [...]" (HERCULANO, 19--, p.25) o autor, em nota, explica que o significado de iman seria pontífice e que os califas reuniam tanto o poder imperial como o pontificiado. A presença divina é não apenas 
referida nesse fato, mas também em todo o diálogo, pois o faquir, ao mesmo tempo em que anunciava ou sugeria os acontecimentos, justificava-os sempre como sendo desígnios de Deus.

Durante todo o tempo, Al-ghafir insiste no fato de que um dos filhos do rei irá morrer naquele mesmo dia, e que o próprio soberano é que deveria escolher a quem caberia tal destino. Mas, se como foi visto acima, a morte em luta contra os infiéis cristãos seria considerada um evento positivo e honroso para Abdu-r-rahman, o que anuncia posteriormente o profeta deixa o rei estarrecido: uma morte desonrada para o filho preterido pelo monarca, no próprio palácio real e pelas mãos de um algoz ou assassino.

Depois de um prolongado e tortuoso diálogo, cheio de metáforas e ambiguidades, no qual crescia a expectativa de revelação da desgraça, e o monarca encontrava-se, já, completamente prostrado pelas insinuações, o profeta, finalmente, faz o seguinte esclarecimento: “Amanhã, a estas horas, teu filho Abdallah ter-te-á já privado da coroa para a cingir na própria fronte, e o teu sucessor, Al-haken, terá perecido sob um punhal d'assassino." (HERCULANO, 19--, p.23). E, para comprovar tal acusação, obviamente refutada pelo rei, o faquir mostrou-lhe cartas trocadas entre Abdallah e líderes muçulmanos rebeldes, que viviam nas fronteiras e eram inimigos de Abdu-rrahman. Entre tais pergaminhos, o mais importante seria um dirigido a "Umeyya-ibnIshak, guerreiro célebre e antigo alcaide de Santarém, que, por graves ofensas, passara ao serviço dos cristãos de Oviedo com muitos cavaleiros ilustres da sua clientela." (HERCULANO, 19--, p.31). Assim, ficou comprovada, para o rei, a traição de seu filho, Abdallah, que se juntara aos inimigos muçulmanos e até cristãos para tentar tomar o poder. 
Nas palavras fortes pronunciadas pelo soberano árabe, sobre a traição de Abdallah, talvez seja possível apreender a expressão da caracterização fatalista, violenta e intensa, comumente atribuída aos muçulmanos:

Agora estou tranqüilo... bem tranqüilo... Abdallah, o traidor que era meu filho, não concebeu tão atroz desígnio. Alguém lh'o inspirou: alguém verteu naquele ânimo soberbo as vãs e criminosas esperanças de subir ao trono por cima do meu cadáver e do de Al-haken. Não desejo sabê-lo para o absolver; porque ele já não pode evitar o destino fatal que aguarda. Morrerá; que antes de ser pai fui califa, e Deus confiou-me no Anadaluz a espada da suprema justiça. Morrerá; mas hão de acompanhá-lo todos os que o precipitaram no abismo. (HERCULANO, 19--, p.33)

Abdu-r-rahman determina, então, a execução de seu filho e dos demais envolvidos na conspiração. A violenta punição do califa é assim descrita de forma breve, mas impressionante: “A cabeça de Abdallah caiu aos pés do algoz na própria câmara do príncipe [...]. [...] foi um dia de sangue para Córdoba e de luto para muitas das mais ilustres famílias." (HERCULANO, 19--, p.35 - 36).

Daí em diante, narra-se a influência implacável que o profeta e faquir passou a exercer sobre o rei, que se tornara absolutamente melancólico. Em um excerto, no qual se traduz a tristeza que perpassava o cotidiano do monarca, expõe-se, também, um pouco da cultura árabe através de referência ao harém, que se faz presente no palácio de Abdu-r-rahman:

Encerrado, durante os últimos tempos da vida, no palácio de Azzahrat, a maravilha de Espanha, abandonara os cuidados do governo ao seu sucessor Al-hakem. Os gracejos da escrava Nuirat-eddia, a conversação instrutiva da bela Ayecha, e as poesias de Mozna e de Sofia eram o único alívio que adoçava a existência aborrida do velho leão do islamismo. (HERCULANO, 19--, p.39)

Apenas no final da trama, quando o rei já está para morrer, revela-se o 
segredo de Al-ghafir, tornando-se, assim, também claro, o significado do título da narrativa, como veremos adiante. $\mathrm{O}$ califa, pressentindo a chegada de sua morte, dirige as seguintes palavras ao faquir, cuja presença no palácio, além de frequente, era sempre nociva para o ânimo tão fragilizado do monarca:

Conheço que se aproxima a hora fatal - dizia o califa. Nestas veias em breve se gelará o sangue; mas, santo faquir, não me será lícito confiar na misericórdia de Deus? Derramei o bem entre os muçulmanos, o mal entre os infiéis, fiz emudecer o livro de Jesus perante o de Mohamed, e deixo ao meu filho um trono firmado no amor dos súditos e na veneração e no temor dos inimigos da dinastia dos BenuUmeyyas. Fiz quanto a um homem era dado fazer pela glória do Islã. Que mais pretendes? - Porque, não tens lábios para o pobre moribundo, senão palavras de terror? - Porque, há tantos anos, me fazes beber, gole a gole, a taça da desesperação? (HERCULANO, 19-, p.42 - 43)

Nota-se aqui, de forma emblemática, um padrão recorrente na narrativa, no qual se inverte a expectativa cristã referente aos povos infiéis. Pela voz de um muçulmano a mesma caracterização comumente associada aos árabes, como aqueles que não são fiéis a Deus ou à religião, portanto, os infiéis, é agora atribuída aos cristãos.

Finalmente Al-ghafir revela a sua trama de vingança, relembrando ao rei fatos ocorridos anteriormente, quando o soberano determinou que um certo Mohammed-ibn-Ishak tivesse uma morte indigna. Mohammed seria, na verdade, irmão de Al-ghafir, e para executar sua vingança contra Abdu-r-rahman, o faquir assumiu uma identidade falsa aproximando-se e ganhando a confiança do rei com seu discurso profético e sua fama de santo. Sabe-se, então, que ele era, de fato, o Alcaide de Santarém e que, fingindo ter desaparecido, consegue armar a conspiração contra o rei, culminando com a execução de Abdallah, determinada por seu próprio pai, Abdu-rrahman.

Mas, se o motivo manifesto da narrativa para o conflito é apresentado como 
uma vingança entre dois muçulmanos, refletindo sobre o sentindo geral do conto e retomando especificamente as últimas palavras de Abdu-r-rahman, expostas acima, parece pertinente aventar-se a hipótese de uma punição apresentada na narrativa pelos atos anti-cristãos do monarca. De fato, as seguintes palavras do califa - "Derramei o bem entre os muçulmanos, o mal entre os infiéis, fiz emudecer o livro de Jesus perante o de Mohamed [...]" - parecem demasiado fortes para o contexto português cristão e romântico do século XIX. Por trás da cegueira patente de Abdu-r-rahman, que se deixou enganar por Al-ghafir, não haveria também, de forma subjacente, a insinuação de uma cegueira religiosa?

\section{III.2.5 - A Dama Pé-de-Cabra}

Considerada a única narrativa propriamente fantástica na produção de Alexandre Herculano, e uma das únicas, também, no romantismo português, "A Dama Pé-de-Cabra" foi publicada pela primeira vez na O Panorama, em 1843.

Embora se trate de uma trama relativamente simples a organização narrativa é o que de fato constitui a complexidade do texto, perfazendo-se assim imbricadas relações entre os diversos contextos aí abarcados. Conforme salienta Ofélia Paiva Monteiro, a lenda foi desenvolvida "em vários níveis narrativos, que implicam uma curiosa estruturação temporal [...]”. (MONTEIRO, s.d., p.27)

A representação dos mouros nesse conto se dá, aparentemente, como um elemento de fundo, constitutivo de parte do contexto histórico aí contemplado, mas 
veremos adiante alguns aspectos que acrescentam possibilidades significativas interessantes para se pensar sua figuração na obra herculaniana. A principal referência temporal remete à época da ocupação muçulmana na Espanha, apresentando-se, mais especificamente, o XI século.

A trama, bastante conhecida, inicia-se com a união entre D. Diogo Lopes, senhor de Biscaia, e certa dama que ele encontrara em uma penha, localizada na fronteira de suas terras. Depois que tiveram dois filhos, D. Inigo Guerra e D. Sol, confirma-se parte de um mistério que vinha sendo prenunciado: a natureza assombrosa e diabólica da mulher de D. Diogo. Certo dia, ao ver o seu cachorro ser morto pela cadela, que pertencia a sua esposa, o senhor de Biscaia quebra o juramento feito a ela, de nunca se benzer, e decorre então a seguinte cena:

Ui! - gritou sua mulher, como se a houveram queimado. O barão olhou para ela: viu-a com os olhos brilhantes, as faces negras, a boca torcida e os cabelos eriçados:

E ia-se alevantando, alevantando ao ar, com a pobre D. Sol sobraçada debaixo do braço esquerdo: o direito estendia-o por cima da mesa para seu filho, D. Inigo de Biscaia.

E aquele braço crescia, alongando-se para o mesquinho, que, de medo, não ousava bulir nem falar.

E a mão da dama era preta e luzidia, como o pelo da podenga, e as unhas tinham-se-lhe estendido bem meio palmo e recurvado em garras. (HERCULANO, 19--, p.14)

Passa-se, então, para a segunda trova, na qual se fica sabendo que D. Diogo Lopes está agora cativo dos mouros e que seu filho, já adulto, quer salvá-lo. Aconselhando-se sobre o assunto com o pajem, Brearte, D. Inigo acaba contando-lhe outra história, referente à origem de sua mãe, a Dama Pé-de-Cabra. Narra-se, assim, a lenda do Conde Argimiro, o Negro, e Astrigildo Alvo. Argimiro, que ficara dois anos em Toledo, lutando nas guerras do Rei de Wamba, ao voltar pra casa descobre o adultério da condessa, sua esposa, assassinando-a, por este motivo, junto com o seu 
amante Astrigildo.

O episódio é descrito com elementos fantásticos e representa, na verdade, a punição à quebra de uma promessa feita por Argimiro ao seu pai, de nunca matar "fera em cama e com cria" (HERCULANO, 19--, p.210). A mulher morta em estado de adultério seria, assim, a própria Dama que, centenas de anos depois, D. Diogo viria a encontrar nas penhas.

A referência ao Rei de Wamba, nessa passagem, revela um importante elemento temporal do texto, pois, considerado o último rei godo, esse personagem histórico teria vivido no VII século. Assim, entre o plano narrativo concernente a história de D. Diogo Lopes e aquele, relativo à origem da Dama Pé-de-Cabra, há uma diferença temporal de aproximadamente quatro séculos.

Prosseguindo a trama narrativa, D. Inigo Guerra, aconselhado por Brearte, decide procurar sua mãe para pedir que o auxilie a salvar D. Diogo do cativeiro mouro em Toledo. Assim, em cenas permeadas por fatos sobrenaturais a Dama e um certo ónagro, que seria a representação de Astrigildo, ajudam a resgatar o pai de D. Inigo. Ao fim da narrativa, fala-se da proximidade estabelecida entre D. Inigo Guerra e sua mãe, a Dama Pé-de-Cabra, insinuando-se, também, um pacto com Belzebu e a existência de vários outros mistérios ocorridos no castelo depois de sua morte, que não foram retratados na narrativa.

Helena Carvalhão Buescu, considerando a possibilidade de entendimento de A Dama Pé-de-Cabra "como narrativa alegórica, funcionando ao modo de uma parábola construída sobre um gesto metafórico" (BUESCU, 2005, p.88), elabora uma análise bastante interessante do conto. A autora orienta-se, entre outros parâmetros, pela relação entre predação e domesticidade, extraída da temática do caçador caçado, 
implicada na narrativa. Aproveitando as reflexões suscitadas pelo artigo de Buescu, principalmente no que se refere à questão da dimensão alegórica do conto e da temática da domesticidade aí ressaltada, encontramos também, tangencialmente a essa proposta, um aspecto relevante contido na estruturação narrativa: a alternância entre a periculosidade advinda do contexto interno, ou doméstico, e do externo, ou estrangeiro.

A figura feminina, representada pela Dama Pé-de-Cabra, na história de D. Diogo Lopes, e pela Condessa de Biscaia, do século VII, no episódio referente ao Conde Argimiro, estaria, a princípio, circunscrita ao espaço interno ou doméstico. Por outro lado, D. Diogo Lopes, D. Inigo Guerra e Argimiro, que seriam as figuras masculinas de maior destaque na narrativa, além do âmbito doméstico, transitam, também, pelo espaço externo, participando, os dois primeiros, das guerras contra os mouros, e o Conde Argimiro, quatro séculos antes, lutando contra rebeliões contrárias ao rei de Wamba, na região de Toledo.

A presença moura no conto parece, mesmo, pontuar passagens importantes da lenda referente a D. Diogo Lopes e ao seu filho, D. Inigo Guerra. D. Diogo, ao prometer à Dama que nunca mais faria o sinal da cruz, apresenta, como compensação à falta religiosa, a possibilidade de matar um grande número de mouros, como disposto a seguir: "De que servem benzeduras? Matarei mais duzentos mouros e darei uma herdade a Santiago. Ela por ela. Um presente ao apóstolo e duzentas cabeças de cães de Mafamede valem bem um grosso pecado." (HERCULANO, 19--, p.10). Depois, quando ocorre o episódio assombroso da transformação de sua mulher, D. Diogo, tentando se refazer da desgraça sofrida, decide ir a Toledo "caçar mouros":

D. Diogo Lopes viveu muito tempo triste e aborrecido, porque já não se atrevia a montear. Lembrou-se, porém, um dia de espairecer sua tristura, e, em vez de ir à caça dos cerdos, ursos e zebras, sair à caça de mouros. (HERCULANO, 19--, p.15). 
E, finalmente, ele acaba sendo aprisionado pelos mouros e é por esse motivo que seu filho, com intento de salvá-lo, procura sua mãe. Já a história de Argimiro é, de certa forma, determinada pela luta contra os estrangeiros, pois é pela necessidade de ir para Toledo lutar pelo Rei de Wamba, que ele se ausenta de sua casa e, ao retornar, descobre a traição da esposa.

Percebe-se, assim, que ação narrativa é movida pela alternância entre um perigo externo, representado pelos estrangeiros, sejam eles mouros ou apenas invasores vindos de outras regiões da Europa, e pela ameaça interna, representada nos dois casos pela mesma figura feminina. A ameaça externa relaciona-se aos fatos históricos ocorridos na península Ibérica, mas é no componente interno e doméstico que residem as questões mais assombrosas, elaboradas na narrativa com elementos fantásticos. A personagem da Dama Pé-de-Cabra constituída por Herculano, cuja lenda teria sido extraída do livro de Linhagens do Conde D. Pedro (MONTEIRO, s.d., p.27), não tem realmente nenhuma herança familiar moura, conforme é enfatizado no seguinte excerto da narrativa:

De nunca dar tréguas à mourisma, nem perdoar aos cães de Mafamede? Sou bom cristão. Guai de ti e de mim, se és dessa raça danada!

Não é isso, dom cavaleiro - interrompeu a donzela a rir. (HERCULANO, 19--, p.10)

É importante ressaltar que, se na lenda original do livro de linhagens (ver ANEXO) não há nenhuma referência a esse assunto, em algumas lendas populares, entretanto, as mouras são apresentadas com os pés de cabras, como é o caso da "Torre de Dona Chama" (RODRIGUES, s.d.), que tem como figura principal uma princesa moura com pernas de cabra (PARAFITTA, 2006, p.85), lenda retomada no romance 
contemporâneo de Ernetos Rodrigues de mesmo título. Assim, identificamos na citação acima uma opção, não arbitrária, por manter essa personagem tão misteriosa, com traços certamente demoníacos, como um fruto apenas da "alta linhagem" (HERCULANO, 19-, p.8) da família ibérica.

Os mouros, reificados como uma caça pouco mais importante que cerdos e ursos, funcionam, em um primeiro momento como forma de remissão para a culpa de D. Diogo pelo casamento com a Dama. Depois, em um movimento circular, é exatamente a intervenção da Dama Pé-de-Cabra que define o salvamento de D. Diogo do cativeiro mouro em Toledo. Assim, os perigos externos, representados pelos mouros ou outros estrangeiros, parecem, de fato, convergir para uma força maior, localizada em um âmbito interior, que seria a um tempo a origem mesmo desses perigos, mas também a possibilidade de sua solução.

\section{III.3 - Conclusão}

Pensando o conjunto dos textos literários de Alexandre Herculano percebemos que há algumas oscilações entre as diversas formas de se retratar o elemento mouro. As obras Eurico, o presbítero e $O$ Bobo apresentam, em uma primeira visada, as perspectivas mais diversificadas no que se refere ao assunto.

Embora representem um elemento pouco significativo no enredo de $O$ Bobo, as referências aí contidas, sobre os povos árabes, são bastante interessantes, principalmente se compararmos ao tratamento que lhes confere Herculano em Eurico. Nesta obra, coloca-se, em um primeiro plano, o confronto entre os valores 
heróicos dos godos, inseridos em uma perspectiva cristã e moralista, e as atitudes imorais e infames daqueles que adoravam Maomé. Se Alexandre Herculano identifica os dois povos como bárbaros, a questão religiosa parece ser, inicialmente, o elemento determinante para a condenação dos árabes e a exaltação dos visigodos. Por outro lado, percebemos em $O$ Bobo, como fato bastante inusitado, uma atitude menos comprometida com a causa cristã e, portanto, mais isenta na representação do elemento árabe no interior da cultura ibérica. Destaca-se, inclusive, nesta narrativa, a “superioridade intelectual” dos mouros em relação aos cristãos.

Tal diversificação de abordagem poderia ser, em parte, atribuída à própria especificidade do período histórico contemplado. No caso de Eurico, século VIII, é retratada, exatamente, a invasão da Península pelos mouros, por outro lado, em $O$ Bobo, a disputa com os muçulmanos já não se insere no foco principal do conflito pela nacionalidade. Considerando, inclusive, as colocações de Alexandre Herculano na História de Portugal, Ana Rita Gaspar Moreira evidencia a mudança de percepção referente aos muçulmanos, do período das invasões para o século XII, quando os mouros já estão instalados na Península Ibérica:

Depois do terror da invasão muçulmana e do ódio que inspira a reação goda das Astúrias, a tensão do conflito abranda, porém, quando, no século XII, são já muitos anos de batalha contínua e os árabes parecem definitivamente instalados na planície ibérica. (MOREIRA, 2005, p.87)

A pesquisadora traz à tona, ainda, a metáfora do encontro entre o rio e o mar utilizada pelo próprio Herculano, historiador, para descrever essa posterior relação pacífica entre os muçulmanos e os iberos.

Seguindo uma linha de raciocínio semelhante, Margarida Cardoso ressalta 
um aspecto que parece também significativo para compreensão da obra literária herculaniana: a relação entre "a índole da fábula romanesca e a época em que é colocada" (CARDOSO, 2003, p.173), ou seja, maneira como a fábula é elaborada na ficção de Herculano dependeria do contexto histórico aí contemplado. Margarida Cardoso explica, abaixo, mais detalhadamente, tal hipótese, considerando para isso dois momentos específicos retratados por Herculano, o século XIV, ou a época do reinado de D. João I, e o período das invasões árabes e da reconquista cristã:

As obras que evocam, no século XIV, os sucessos da crise que consolidou o espírito nacional e trouxe a centralização do poder régio com o apoio da burguesia e de movimentações populares ("Arras por Foro de Espanha", "A Abóbada", O Monge de Cister) são as que - apoiadas pelas crônicas de Fernão Lopes, admirativamente lidas - se recobrem de mais pitoresco na descrição dos ambientes e na recriação dos conflitos sociais. Os textos cuja matéria histórica recua até os tempos da invasão árabe e da reconquista cristã na Península ("O Alcaide de Santarém", "Destruição de Áuria", Eurico, o Presbítero) adquirem um tom épico lendário que Herculano justifica em nota (...) (CARDOSO, 2003, p.173 - 174)

Assim, pelas palavras do próprio Herculano, Margarida Cardoso encontra um lastro consistente para tal suposição. A autora destaca no prólogo de Eurico a afirmativa de Alexandre Herculano sobre a impossibilidade de se constituir o romance...

Tendo em vista, especificamente, o plano geral das obras, Eurico, o presbítero e $O$ Bobo, pode-se estabelecer também um paralelismo entre a forma como o elemento mouro é apresentado e a maneira como se estrutura todo o restante da narrativa. Em Eurico, a representação mais evidente dos mouros é um tanto tendenciosa e reproduz concepções redutoras e caricatas sobre esses povos e, de modo geral, a narrativa organiza-se, também, de forma polarizada e dicotômica. Já em $O$ Bobo, o mouro é retratado de uma maneira mais abrangente e consistente, assim como a trama 
narrativa apresenta uma maior complexidade, implicando uma profícua problematização de seus personagens.

Mas, para além da divergência mais patente, nota-se, entretanto, que essas mesmas obras apresentam-se matizadas de outras perspectivas que acrescentam, ainda, em seu interior, múltiplas possibilidades de expressão do elemento mouro. Conforme foi visto, há, inclusive, uma associação entre cristianismo e decadência em Eurico e a inclusão dos invasores mouros em um plano divino cristão. E, a trama de $O$ Bobo abarca, também, alguns complicadores no que se refere à ênfase em uma diferenciação étnica caricatural entre mouros e portugueses, identificada na forma como são retratados os muçulmanos convertidos ao cristianismo.

A narrativa que teria dado origem a Eurico, no entanto, compreende uma disposição bem mais óbvia e homogênea que o emblemático poema épico de Alexandre Herculano. De forma mais simplista, "Destruição de Áuria" apresenta, em uma organização simplesmente dicotômica, o conflito entre mouros e cristãos, centrado, basicamente, na figuração desonrosa e infame relativa aos muçulmanos em oposição à caracterização heróica dos godos. E ainda, os aspectos negativos referentes ao comportamento pernicioso dos mouros são atribuídos em grande parte ao islamismo, enfatizando-se, assim, o cunho religioso do conflito.

Importa ressaltar que esse conto não foi acolhido por Herculano na seleção feita pelo autor dos textos literários componentes de suas Lendas e Narrativas. E posteriormente, conforme já foi visto, a utilização parcial de tal trama, no enredo de Eurico, foi acrescida de outros vieses referentes à figuração do elemento mouro que comprometeram, em alguma medida, a dicotomia inicial apontada na obra.

A trama de "A morte do Lidador", referente ao ano de 1170, bem posterior 
ao século VIII, retratado em Eurico e "Destruição de Áuria", e posterior, portanto, ao principal período das invasões mouras, ressaltado por Margarida Cardoso como propício ao tom épico e heróico da obra herculaniana, compreende, entretanto, um cariz absolutamente lendário e fabuloso na representação do conflito entre portugueses e mouros. Se em Eurico os exércitos são, de modo geral, equivalentes em número de guerreiros, apresentando-se, inclusive, uma analogia entre os diversos níveis hierárquicos componentes do lado espanhol e do árabe, a narrativa de "A morte do Lidador" já contempla uma evidente discrepância entre o numeroso exército muçulmano e o pequeno e heróico grupo cristão. Tal representação remonta ao imaginário mítico-lendário referente às lutas entre portugueses e mouros, nas quais se perfazem essas mesmas condições de desigualdade fabular. A narrativa concentra-se, principalmente, na representação grandiosa de Gonçalo Mendes da Maia, figura emblemática da heroicidade e valentia cristã na luta contra os chamados infiéis.

Assim, a exemplo do que ocorre em "Destruição de Áuria”, “A morte do Lidador" alinha-se a Eurico, o presbítero no que se refere à representação do conflito entre mouros e ibéricos, implicando, por conseguinte, o confronto entre cristianismo e islamismo. Mas, comparando com a estruturação dicotômica e simplificada como são organizados o contexto cristão e o muçulmano nesses contos, tornam-se mais patentes, na narrativa de Eurico, as fissuras que comprometem aquela composição polarizada inicial. A exemplaridade do passado heróico, particularmente identificado em "A morte do Lidador", constituído pela vitória grandiosa dos portugueses sobre os mouros, encontra em Eurico quase o seu reverso, na medida em que os mouros são referidos como instrumento divino para derrotar um império godo já decadente.

Mas, é exatamente a partir desse ponto de divergência entre as narrativas, 
que se pode depreender outra perspectiva comum na representação dos mouros. De modo bastante diverso, tanto a narrativa de "A morte do Lidador" como a de Eurico, o presbítero evidenciam a função utilitária dos muçulmanos na luta contra os cristãos, culminando com a expressão reificada dos mouros.

No conto, o absoluto antagonismo dos mouros gera um apagamento de seus contornos reais e sua figuração constitui-se de forma esvaziada, identificando-os apenas como opositores dos portugueses. Em Eurico, uma dobra que afeta a orientação dicotômica do texto coloca-se, exatamente, na identificação de Tárique como um anjo divino enviado para exterminar o poderio godos. O sentido geral da narrativa parece abarcar, assim, uma significação endógena centrada no império gótico, abordando o mouro como elemento meramente utilitário. O antagonismo dos muçulmanos estaria, desse modo, inscrito em um plano maior, cujo epicentro constitui-se apenas da problemática referente à corrupção dos godos e da necessidade de extinção desse império viciado para que se viabilize uma renovação.

Assim, pode-se estabelecer uma relação entre o aspecto endógeno verificado em algumas obras herculanianas e a reificação dos mouros também aí presente. Na medida em que o foco da questão volta-se para o contexto nacional ou ibérico os elementos extrínsecos passam a funcionar como acessórios para se problematizar o assunto central. Dessa forma, em Eurico, a representação dos mouros funciona, em parte, como suporte para se colocar a questão da corrupção e decadência dos godos, atuando, ainda, como instrumento viabilizador de higienização e renovação de tal sociedade. Já em “A morte do Lidador", os muçulmanos constituem apenas um contraponto para se evidenciar a heroicidade dos portugueses, particularmente, do fabuloso Gonçalo Mendes da Maia. 
Outra narrativa, na qual se pode verificar a reificação dos muçulmanos promovida pelo ponto de vista endógeno predominante na trama, é "A Dama Pé-deCabra". A presença dos mouros tangencia o plano principal da narrativa, funcionando como um demarcador dos momentos importantes da trama. Delineia-se uma oscilação entre a longínqua periculosidade externa, representada pelos muçulmanos, e o perigo interno mais premente e constante associado à figura feminina da Dama. Mais uma vez a questão principal é endógena e diz respeito à falibilidade ou ao lado obscuro da alta linhagem ibérica. E os mouros são aí referidos como elementos adjacentes a essa trama, funcionando como instrumento de remissão para os erros ou pecados cometidos, sendo a sua derrota e morte, por exemplo, objeto de barganha religiosa. Parece válido relembrar as seguintes palavras de D. Diogo Lopes, tão representativas dessa instrumentalização à qual referimos: "De que servem benzeduras? Matarei mais duzentos mouros e darei uma herdade a Santiago. Ela por ela. Um presente ao apóstolo e duzentas cabeças de cães de Mafamede valem bem um grosso pecado." (HERCULANO, 19--, p.10).

Mas, se como dissemos, o conjunto da obra literária de Alexandre Herculano abrange figurações um tanto diversificadas do elemento mouro, em algumas delas encontram-se perspectivas avessas àquela colocada acima, em que se destaca o viés endógeno e reificante. Referimo-nos ao tratamento individualizante e humanizador, no qual o mouro ganha voz e expressa, inclusive, uma visão crítica coerente em relação aos cristãos.

Curiosamente, um dos textos em que ocorre tal representação dos mouros é exatamente Eurico que, como vimos acima, apresenta também a expressão reificada desses elementos. Ao dar voz ao chefe árabe, Tárik, a narrativa constitui uma 
argumentação bastante consistente que poderia mesmo legitimar a motivação religiosa islâmica tanto quanto, de modo geral, ocorre com o cristianismo. Outro muçulmano que ganha voz, nessa mesma obra, é Abdulaziz, que em um discurso bem próximo ao da voz narrativa apresenta uma argumentação crítica também consistente, dirigida ao comportamento vicioso e irresponsável dos godos, destacando, principalmente, sua embriaguez e falta de valores morais.

Em $O$ Bobo, conforme foi visto, a fala do jardineiro mouro do palácio, Abul-Hassan, expõe os despropósitos cristãos e as práticas cruéis cometidas em suas empreitadas africanas de "caça aos mouros". Mas, poderíamos pensar que os discursos de Abul-Hassan como também o de Abdulaziz, em Eurico, funcionam como instrumento de reflexão sobre os godos e o cristianismo, retornando, desse modo, ao foco interno ou endógeno. Ainda assim, é significativo o fato de esses personagens mouros serem colocados, em determinado momento, como sujeitos enunciadores capazes de elaborar uma perspectiva crítica plausível de seus opositores.

Já o personagem mouro, Alé, de $O$ Monge de Cister, que tem uma participação relativamente significativa na trama, expõe, em uma de suas poucas falas, o que seria um fundamento humanitário do islamismo: "A minha lei, Padre cristão, obriga-me a socorrer o desventurado: obedeci à lei.” (HERCULANO, 1959, p.485). Tal frase refere-se e é sustentada pela compaixão demonstrada por Alé ao salvar e cuidar de Beatriz. Verifica-se, assim, a defesa consistente do islamismo, fundamentada em ações humanitárias, apresentada no discurso de um personagem mouro.

O exemplo mais expressivo da figuração autônoma do mouro na obra herculaniana, na qual sua expressão constitui-se em um âmbito próprio, desvinculado de associações com o contexto cristão, ocorre em "O Alcaide de Santarém". Por ter como 
foco apenas os muçulmanos e a sociedade por eles constituída na Espanha, o conto abrange, inclusive com uma poeticidade exótica, expressões da cultura e sociedade árabe em tal contexto. Pela voz dos personagens acompanha-se, em alguns momentos, a inversão da perspectiva cristã, seja pela denominação de infiéis dada aos espanhóis, ou ainda mais pela defesa da chamada Guerra Santa. A história de vingança e intrigas, com notas de violência excessiva e maquiavelismo que, ainda que sejam encontrados, também, em outros textos de Herculano, parecem alcançar aqui um grau superlativo. E, conforme foi apresentado anteriormente, ao final da narrativa revela-se uma punição trágica que, embora seja imanente à trama, talvez possa ser extrapolada e sugerir também uma perspectiva cristã aí embutida de condenação às atitudes violentas e anticristãs dos muçulmanos.

Acompanha-se, ainda, em alguns pontos da obra literária de Herculano, a presença de personagens que compreendem a conjunção de elementos mouros e cristãos. Em $O$ Bobo, como visto, isso pode ser verificado em Martim Eicha, o cônego de Lamego, personagem de origem moura, que converteu-se ao cristianismo, e, também, no irmão de Abul-Hassan, nomeado apenas com as alcunhas depreciativas, para tal contexto, de tornadiço e árabe-cristão. Em ambos os casos o que se observa é a reafirmação constante da origem moura, e, especificamente, no comportamento de Eicha verifica-se, também, que a conversão religiosa ao cristianismo não se traduz em benefício moral para o personagem. Como visto, tal perspectiva se contrapõe à tendência encontrada na historiografia de Alexandre Herculano e de outros historiadores oitocentistas de atribuir à religião e não à etnia a configuração moral dos povos.

Em $O$ Monge de Cister, tal confluência religiosa ou étnica entre cristãos europeus e muçulmanos mouros apresenta-se de forma um pouco distinta. Conforme 
colocado anteriormente, a narrativa aborda, por um lado, a expressão da pacífica convivência entre cristãos, mouros e judeus, no XIV século, viabilizada pela própria legislação, por outro, o retrato prosaico das intrigas e preconceitos ainda resistentes na sociedade da época. E é nesse contexto um tanto contraditório, que Herculano localiza seu protagonista cristão matizado por componentes mouros. Como vimos, a caracterização moura de Vasco ocorre em diversos planos, mas o que importa aqui é ressaltar a cisão entre a heroicidade e o antagonismo que acompanham o personagem, já originalmente cindido pela remota hereditariedade goda e moura. Assim, conforme também já foi ressaltado, há uma evidente falibilidade tanto do protagonista de feições mestiças como da sociedade da época de D. João I, composta por indivíduos de diversas etnias e religiões. A culpabilidade da decadência aí apresentada, entretanto, parece atribuída, de modo mais contundente, à nobreza, classe que, aparentemente, não abrange componentes étnicos e religiosos de origem judaica ou moura. Mas, cotejando o protagonista de sangue árabe e espírito godo (HERCULANO, 1959, p.454), com os personagens convertidos de $O$ Bobo que, de modo bastante diverso, representam também a junção entre o elemento mouro e o cristão, depreende-se, no mínimo, uma coincidente falibilidade entre os três personagens.

Reafirmamos, assim, a heterogeneidade da figuração do mouro na obra literária de Alexandre Herculano. Embora, tenhamos destacado algumas linhas de força que perpassam algumas obras, não há, de fato, contornos precisos para se descrever tal representação. Acreditamos que a análise específica de cada obra oferece elementos mais complexos para se pensar a presença moura na Península Ibérica do que as poucas interseções encontradas no confronto entre elas. Mas, as perspectivas tão diversas já destacadas fazem pensar em um ponto de vista autoral um tanto múltiplo e abrangente. 
A figuração literária do mouro, que promove tanto a sua reificação como o elogio de sua herança arquitetônica chegando ao reconhecimento de princípios islâmicos, poderia sugerir uma perspectiva autoral desvinculada de preconceitos étnicos ou religiosos. Assim, a representação do mouro na obra herculaniana parece, realmente, comprometida apenas com a trama na qual se insere, sendo esta, também, mais abrangente que o fato histórico aí retratado. 


\section{CAPÍTULO IV - MOUROS E BARBÁRIES NA LITERATURA PORTUGUESA CONTEMPORÂNEA}

\section{IV.1 Os cercos de Lisboa}

Publicado em 1989, o romance, História do cerco de Lisboa, de José Saramago, é citado, muitas vezes, como paradigma para se pensar a elaboração histórica na ficção saramaguiana. De maneira geral, essa obra não é considerada um romance histórico tradicional, mas uma metaficção historiográfica, por se desenrolar, em um primeiro plano, no tempo atual, e, apenas em outro plano, interior a este, apresentar uma abordagem histórica referente à tomada de Lisboa, em 1147. O "não" inserido pelo protagonista Raimundo Silva, em uma obra também intitulada História do cerco de Lisboa, vem servindo para se refletir sobre as diversas negações à história oficial, contempladas nos romances de José Saramago. Nesse sentido, uma frase da narrativa parece, mesmo, exemplar para se pensar a estruturação desse texto, como de outros do autor: "De história sacra, por agora, temos que nos chegue." (SARAMAGO, 2004, p.22)

Mais do que a negação dos monumentos históricos, observamos, nessa obra, uma recusa ao tratamento generalizante dos fatos oficiais. $\mathrm{O}$ narrador aproveita-se ao máximo da liberdade conferida pelo lugar literário de sua enunciação, para elaborar considerações bastante argutas e inusitadas extraídas, principalmente, das subjacências 
dos fatos abordados. Um exemplo disso pode ser verificado pelo modo como o dado histórico, referente ao cerco realizado pelos portugueses, suscita formas interessantes de estruturação, no interior da trama ficcional, que mantêm uma relação de contiguidade com a idéia de cerco. Outro tipo de elaboração, tangencial ao contexto fabular aí contemplado, refere-se à maneira como o antagonismo das partes envolvidas no cerco, portugueses/cristãos e mouros/muçulmanos, é relativizado. De forma bem irônica, apresentam-se contextos, nos quais as divergências entre os aspectos religiosos e culturais entre os dois lados parecem totalmente arbitrários e inconsistentes.

E são justamente reflexões como essas, abarcadas na obra de Saramago, que nos interessam aqui: mais uma vez vemos como a abordagem do mouro na literatura portuguesa gera subsídios para se pensar, de modo bastante significativo, essa cultura, e, extensivamente, as relações humanas aí implicadas.

Como dissemos, o enredo do romance contempla, entre outras coisas, o episódio histórico da tomada de Lisboa pelos portugueses, em 1147, então ocupada pelos mouros. O protagonista Raimundo Silva, revisor de uma editora, ao fazer a correção do livro, História do cerco de Lisboa, começa a conjeturar sobre a fantasiosa hipótese de os cruzados se recusarem a ajudar D. Afonso Henriques em sua empreitada de reconquista da cidade, dominada pelos muçulmanos. Contrariando o seu histórico de revisor sempre correto e rigoroso, Raimundo Silva modifica deliberadamente o texto revisado, através da introdução da palavra "não", em uma frase referente ao assunto, concretizando, assim, a hipótese imaginada. Na narrativa histórica por ele modificada e entregue à editora para publicação, passa a constar, então, que os cruzados negaram sua ajuda aos portugueses.

Essa inesperada intervenção do revisor, além de consequências factuais 
concernentes ao desenrolar da narrativa, - como o conflito com a editora e sua apresentação à Maria Sara - parece constituir-se como o ponto crucial, de onde emerge a condição apontada acima, referente a uma nova possibilidade de estruturação discursiva que, a nosso ver, mimetizaria a concepção, mesmo, de um cerco. Como veremos adiante, diversas relações pessoais, que se configuram ao longo da narrativa, passam a ser descritas como interações entre os dois lados de um cerco. Tentaremos analisar essa questão com maior acuidade ao longo desse capítulo. Antes disso, porém, atentamos para o fato de que há uma interferência incisiva entre o ato subversor de Raimundo Silva, em relação à História do cerco de Lisboa, por ele modificada, e sua própria realidade cotidiana. Ao modificar o texto escrito pelo historiador, o protagonista passa a ter, também, a percepção comprometida, sobre os fatos a sua volta, como se pode verificar na seguinte passagem:

Raimundo Silva, que justamente se encontra nos lugares da antiga cidade moura, tem, desta coincidência histórica e topográfica, uma consciência múltipla, caleidoscópica, sem dúvida graças à decisão que formalmente tomou de haverem os cruzados resolvido não auxiliar os portugueses [...], para Raimundo Silva, e até nova ordem ou até que Deus Nosso Senhor doutra maneira o disponha, Lisboa continua a ser dos mouros [...] (SARAMAGO, 2004, p.60 - 61)

A situação descrita acima, na qual o revisor perambula pela parte moura de Lisboa, retrata, embora de forma emblemática, a confusão estabelecida entre a narrativa histórica por ele revisada e sua própria existência. Antecipa-se, aqui, a permanência histórica dos mouros, que ganhará uma feição mais abstrata ao longo do romance, como forma de alteridade, que ora se aproxima da cultura portuguesa, constituindo mesmo uma identificação, ora figura-se, em um âmbito pessoal, como pólo antagônico, representativo do estranhamento, da ameaça.

Também a seguinte passagem, na qual o revisor vê uma pequena cigana 
pedindo esmolas à porta de um restaurante, corrobora a proposição de uma confluência entre o texto historiográfico modificado por Raimundo Silva e sua percepção da realidade: "o revisor, que, indo atrás dos pensamentos que o ocupam, não viu cigana, mas moura, na hora da primeira necessidade [...] Mas o cerco não acabou, avisam os olhos da cigana." (SARAMAGO, 2004, p.73).

Assim a emergência de uma alteridade estranha, presentificada pelos mouros, e da configuração, mesmo, de um cerco, como mecanismo de separação e ameaça, advêm da intervenção feita por Raimundo Silva em um texto historiográfico, mas alcança o plano narrativo mais abrangente, referente ao romance, no qual está contido este relato histórico. Maria Lúcia Wiltishire de Oliveira aponta três possibilidades discursivas no romance de José Saramago:

Temos ali a confluência de, no mínimo, três tempos, três vozes, três enunciados. Há o discurso literário comandado pelo narrador; há os discursos dos historiadores trazidos à colagem, há um (suposto) discurso histórico-literário da personagem Raimundo. (OLIVEIRA, 2000, p.226)

E o que perpassa essas três linhas narrativas é justamente a questão da alteridade. Nos discursos históricos, representada, de forma mais imediata, pelos mouros; na voz do narrador externo, percebida, principalmente, pela distância que separa Maria Sara e Raimundo Silva; e, naquele suposto texto conduzido pelo revisorescritor, simbolizada pela interação entre Mogueime e Ouroana, e pelo antagonismo entre mouros e portugueses.

Desse último ponto, resulta o outro aspecto que tencionamos tratar nesse texto: o pensamento sobre a cultura portuguesa originado pela presença dos mouros na narrativa. Valendo-se, também, da idéia de cerco que pressupõe a delimitação entre dois lados opostos e rivais, no caso cristãos-portugueses e os mouros-muçulmanos, o 
narrador apresenta, de forma um tanto despretensiosa, a confluência entre as duas culturas aí antagonizadas.

A denominação corrente de bárbaros feita aos mouros é também utilizada nessa obra, como se pode verificar na passagem abaixo, e em muitos outros pontos do romance. Mas, como também se pode perceber no seguinte excerto, a terminologia e os próprios fatos narrados são constituídos de forma irreverente e irônica. Aqui, e ao longo de quase todo o texto, prevalece uma estruturação aparentemente coerente, fundamentada em silogismos irrefutáveis, que resulta, entretanto, em uma expressão absolutamente bizarra dos fatos. Assim, em um tom muito bem-humorado, resultante da leviandade e despretensão com os quais constitui-se o discurso, o narrador apresenta a seguinte reflexão sobre o milagre de Ourique:

[...] aquele milagre de Ourique, celebérrimo, quando Cristo apareceu ao rei português, e este lhe gritou, enquanto o exército prostrado no chão orava, Aos infiéis, Senhor, aos infiéis, e não a mim que creio o que podeis, mas Cristo não quis aparecer aos mouros, e foi pena, que em vez da crudelíssima batalha poderíamos, hoje, registar nestes anais a conversão maravilhosa dos cento e cinqüenta mil bárbaros que afinal ali perderam a vida, um desperdício de almas de bradar aos céus. (SARAMAGO, 2004, p.20)

\section{IV.1.1 - Mouros e portugueses: do antagonismo à identificação}

Dessa maneira, o registro referente ao desperdício de tantas "almas bárbaras" não corrobora nenhum estereótipo generalizante sobre os mouros, mas, contrariamente a isso, ironiza o mito histórico do milagre de Ourique, evidenciando sua expressão nacionalista fantasiosa e grandiloquente. Percebemos, na verdade, que o 
romance de Saramago, valendo-se do fato histórico que traz à tona o cerco de Lisboa, propõe diversas formas de se pensar a relação entre mouros e portugueses, desfazendose o lugar-comum do invasor bárbaro. A mais radical delas nos parece ser revelada na seguinte citação, na qual, contrariando-se inclusive os dados historiográficos, propõe-se que os portugueses devem sua origem, principalmente, aos mouros, em detrimento até mesmo dos godos:

[...] o tempo abre-se em dois ramos para não tocar nesta aldeia rupestre, está assim, a bem dizer, desde os godos, ou os romanos, ou os fenícios, depois é que vieram os mouros, os portugueses de raiz, os filhos e os netos deles, estes que somos [...] (SARAMAGO, 2004, p.74)

Também no seguinte trecho, além de se ressaltar a maior coerência apresentada no discurso de um mouro do que na fala do arcebispo de Braga, confirmase, ainda, a perspectiva, acima referida, de que os mouros constituiriam a predominância étnica em Portugal:

Confrontando as duas falas, pesou ao revisor ver como um simples mouro a quem faltavam as luzes da verdadeira fé, se bem que com patente de governador, soube, em prudência e eloqüência, librar mais alto seu voo que um arcebispo de Braga, apesar de versado em concílios, bulas e doutrinais. Mui natural é propender em nós o desejo de que ganhem em tudo os nossos, e Raimundo Silva, embora suspeitando que haja no corpo da nação a que pertence mais sangue de mourisma do que de arianos lusitanos, teria gostado de aplaudir a dialética de D. João Peculiar em vez de ter de humilhar-se intelectualmente diante de um discurso exemplar de um infiel que não deixou nome na história. (SARAMAGO, 2004, p.74)

Mas, se na ocorrência de provérbios populares como, "Abaixo do Douro todo mundo é mouro", pode-se verificar uma parcial confirmação e afinidade com as citações acima, esse último excerto apresenta uma forma um tanto peculiar de tratar o assunto. $\mathrm{O}$ que, em outro contexto, poderia ser percebido como uma maneira 
preconceituosa de se retratar o mouro ("sangue de mourisma", "infiel", "simples mouro"), nessa passagem, entretanto, revela o despautério desse tipo de colocação. Naquele mesmo tom leviano, quase irresponsável, apontado acima, o narrador articula termos relativos a uma perspectiva viciosa, pela qual os portugueses conceberiam os mouros, de forma a tornar patente a inconsistência dessas atribuições. Abdicando do charme das oblíquas formulações saramaguianas, o resultado significativo da citação acima poderia ser resumido da seguinte forma: os mouros têm o mesmo alcance intelectual que os portugueses; cada cultura tende a considerar-se mais adiantada, inclusive em termos religiosos, do que as outras; e, especialmente, para os portugueses esse julgamento valorativo torna-se absolutamente falacioso, pois, ainda que não admitam, os mouros são parte considerável de sua constituição étnica.

Outro recurso narrativo, utilizado para expressar a indistinção entre a religião muçulmana e a cristã, pode ser observado no emprego de provérbios bíblicos ou do repertório popular referentes ao cristianismo, colocando-se o termo "Alá" no lugar de "Deus", como se pode verificar a seguir: “[...]se a voz do povo é realmente a voz de Alá [...]” (SARAMAGO, 2004, p.66), “[...] mas Alá não costuma ajudar a quem a si próprio não se ajude [...]” (SARAMAGO, 2004, p.62).

Já o seguinte excerto evidencia uma proposição que nos parece ser essencial para se pensar a narrativa de História do cerco de Lisboa. Em uma determinada situação de conflito, se apresenta um diálogo entre um mouro e o almuadem que não enxergava, no qual o mouro se oferece para descrever ao cego tudo o que se passa:

Não importa, vem comigo à muralha, eu digo-te tudo, a formosas atitudes como esta costumávamos nós chamar caridade cristã, o que uma vez mais vem demonstrar quanto as palavras andam ideologicamente desorientadas. (SARAMAGO, 2004, p.177) 
A ironia, insinuada na citação acima, dirigida à pretensão cristã de tentar se apropriar de valores humanitários, que podem ser reconhecidos em várias culturas e religiões, ganha um alcance mais abrangente em sua última frase: "as palavras andam ideologicamente desorientadas". Nessa colocação poderíamos, de fato, entrever a denúncia dos diversos desvios realizados, por exemplo, nos âmbitos, histórico, cultural ou religioso, justamente, pela construção discursiva, ou pelo uso de palavras ideologicamente manipuladas.

Mas, nesse ponto, podemos inferir, também, uma motivação para a atitude aparentemente descompromissada ou, como dissemos, leviana, verificada nas elaborações do narrador da História do cerco de Lisboa. No lugar do confronto direto aos equívocos e contradições relativos à temática histórica e cultural, aí abarcadas, esse texto, apenas, reapresenta, de forma bastante inusitada, as situações viciosas já conhecidas. Mas, é justamente a formatação desses fatos, através de um sarcasmo sutil, sem julgamentos aparentes, que expõe a falibilidade de diversas concepções e fatos historicamente aceitos. Assim, evitando suportes ideológicos declarados, o narrador parece, simplesmente, conjugar, ora com aguda ironia, ora com divertimento escancarado, episódios e comentários que, nessa conformação específica, resultam em disparates.

Uma forma interessante de comunicar a isenção religiosa, seguindo a postura narrativa apontada acima, pode ser verificada no seguinte trecho:

[...] e eram cidade e rio uma glória só, duvidando-se em todo o caso se sob o olhar do Deus dos cristãos ou do Alá dos mouros, se é que não estariam juntos a gozar do espetáculo e a combinar apostas. (SARAMAGO, 2004, p.127)

Aqui, conforme comentado anteriormente, se patenteia mais uma vez a indistinção entre o cristianismo e o maometismo. Mas, abstendo-se de argumentos 
ideológicos, a narrativa apresenta apenas comentários prosaicos e dessacralizadores sobre atuação do Deus cristão e de Alá, resultando assim, de forma implícita, em um escarnecimento do confronto histórico entre as crenças religiosas monoteístas aí implicadas.

Percebe-se, então, que a identificação entre o português católico, que historicamente se percebe como elemento civilizador, e o mouro, ao qual é atribuído o caráter bárbaro, é realizada através de uma construção narrativa que, sarcasticamente, desvenda a arbitrariedade dessa polarização. Mas, se por um lado o esvaziamento de signos, que fundamentariam esse antagonismo, é obtido por uma abordagem desmitificadora e irreverente dos mesmos, por outro, algumas expressões banais, que promulgam o preconceito mútuo entre portugueses e mouros, são também contempladas com ironia. Um exemplo extremo disso pode ser apreciado nas jocosas considerações em torno do epíteto "cão", utilizado tanto por cristãos quanto por mouros para se referirem uns aos outros, de forma ofensiva, conforme apresentado no seguinte trecho: "[...] dos humanos, que tão mau uso fazem do nome de cão, a torto e a direito o atirando a cara dos inimigos, de mouros os cristãos, de cristãos os mouros, de judeus todos juntos." (SARAMAGO, 2004, p.70).

$\mathrm{E}$, dando continuidade às ponderações sobre o caráter contraditório dessa expressão ofensiva, o narrador levanta, com incontido divertimento, outra incoerência da situação, que se refere ao fato de os fidalgos portugueses adorarem seus cães e ainda assim utilizarem essa denominação como forma de insulto aos seus inimigos. Ao final dessa linha de raciocínio, entretanto, ele apresenta, com tom desencantado, uma observação mais grave: "E tudo isto se vai passando por arbitrário critério de homens [...] (SARAMAGO, 2004, p.70). 
Mas, para rematar, de fato, o assunto, a narrativa, levando a termo a irracionalidade da recíproca designação de cão entre mouros e cristãos, apresenta uma imagem igualmente absurda e fantasiosa, que consegue expressar, ao mesmo tempo, a condição trágica, cômica e arbitrária da situação:

[...] talvez se levantássemos este empedrado moderno do Largo de Santo António da Sé e cavássemos fundo nos aparecesse um alicerce do tempo, algumas escamas de ferrugem de antigas armas, um cheiro de tumba, dois confundidos esqueletos, de guerreiros, não de amantes, gritaram ao mesmo tempo, Cão, e ao mesmo tempo um ao outro se mataram. (SARAMAGO, 2004, p.71)

Buscamos, nesse tópico, comentar alguns dos tantos registros nos quais a figuração do mouro, no romance História do cerco de Lisboa, se constitui pela aproximação ou mesmo identificação com os portugueses. Observamos, na elaboração narrativa dessa obra, uma articulação muito precisa e irônica, que destitui o antagonismo entre o pólo civilizador português e seu oposto, presentificado pelo bárbaro mouro, através de representações que evidenciam o caráter arbitrário dessa polarização. Para isso são elaboradas, de forma despretensiosa, em nuances que vão do bom-humor ao sarcasmo, estruturas que denotam a confluência entre a cultura portuguesa e a moura, passando, por exemplo, pelos signos religiosos, onde deliberadamente se toma Alá pelo Deus cristão e vice-versa, e, também, pela constituição étnica dos portugueses, na qual se diz haver "mais sangue de mourisma do que de arianos lusitanos" (SARAMAGO, 2004, p.74).

E se, ao longo da narrativa, os mouros são chamados de bárbaros sendo referenciados, ainda, segundo diversas outras concepções preconceituosas, isso ocorre, conforme já foi discutido, para se evidenciar o fundo patético e precário sobre o qual está assentado esse tipo de atribuição. Mas, se o que resulta de toda essa performance 
textual é, de fato, uma identificação entre mouros e portugueses, na citação abaixo, pode-se acompanhar uma outra possibilidade de diferenciação cultural que é, realmente, endossada pela narrativa:

[...] treze mil homens que falam sabe-se lá como e que, tendo sentimentos, quem o duvida, os exprimem tão distantemente da nossa compreensão que mais perto estarão eles dos seus inimigos mouros do que de nós, que temos título e bandeira de descendentes. (SARAMAGO, 2004, p.183)

Os treze mil homens aí mencionados são os portugueses participantes do cerco à cidade de Lisboa e o trecho se refere à dificuldade do revisor-autor Raimundo Silva em reconstituir, nos personagens de sua narrativa ficcional, a personalidade, as características subjetivas e culturais, do homem português daquela época. Mas, como dissemos, o excerto ressalta um descompasso cultural, que não pode ser atribuído à diversidade entre mouros e portugueses. Contrariamente a isso, a elaboração desse fragmento sugere que seria na história, em um âmbito, mesmo, cronológico, que poderia ser encontrado o verdadeiro fator determinante das disparidades culturais. $\mathrm{O}$ grande espaçamento temporal, de quase mil anos, que separa o autor Raimundo Silva do período histórico abordado em sua narrativa, parece se configurar como principal entrave para o entendimento da atmosfera cultural a ser retratada. Mas, o que aqui se apresenta como uma proposição pouco incisiva será, em outros momentos, retomado de forma bem significativa e instigante. Abstendo-se de julgamentos ou hierarquias valorativas, a narrativa volta-se para o seu plano histórico, ano 1147, para apresentar diversas ações humanas, aparentemente espontâneas, mas sobre as quais se propõe haver a intervenção condicionante do contexto cultural da época.

Assim, como veremos no tópico IV.1.2, há um constante questionamento sobre o reflexo da condição histórica e cultural no comportamento afetivo e até sexual 
dos personagens, colocando-se em causa o caráter natural ou instintivo que costuma ser atribuído a essas ações. Ressaltamos a sugestão, anteriormente apresentada, de um deslocamento da alteridade cultural dos âmbitos religiosos ou étnicos, por exemplo, para o contexto histórico temporal. Essa proposta não implica, entretanto, a inserção do mecanismo cultural em um processo evolutivo ou progressivo, conforme discutiremos, também, mais adiante.

\section{IV.1.2 - Outros cercos}

Como já foi mencionado anteriormente, há uma contaminação da concepção de cerco, originada da história da tomada de Lisboa - que estando em poder dos mouros, foi sitiada pelos portugueses -, para outros tipos de interações pessoais, elaboradas no romance. A migração desse conceito se faz mais nítida na passagem do âmbito histórico, abarcado no romance, para o primeiro plano narrativo, definido em um contexto temporal recente, no qual figuram, entre outros, os personagens Raimundo Benvindo Silva e Maria Sara.

Percebe-se, pela voz do próprio Raimundo Silva, a apropriação dessa estrutura para a descrição de outro evento, independente da temática histórica do romance, quando é chamado à editora para explicar o "erro" cometido na revisão, e ele, então, descreve, metaforicamente, a situação, colocando-se como um cristão jogado em uma arena, cercado por um leão, que seria o diretor literário: "O leão também está sentado e olha, podemos supor que lambe os beiços e arreganha os colmilhos, enquanto avalia a consistência e o sabor das carnes do pálido cristão.” (SARAMAGO, 2004, 
p.82). A exposição do episódio segue-se com constantes referências a essa relação entre vítima, Raimundo Silva, e a fera ameaçadora que poderia atacá-lo a qualquer momento: “O leão reapareceu subitamente, rugindo, mostra a dentuça assustadora, as garras intactas e afiadas, agora a nossa única esperança, perdidos na arena, é que Tarzan surja finalmente [...]" (SARAMAGO, 2004, p.87).

$\mathrm{Na}$ verdade, essa conjuntura concretiza o que já havia, anteriormente, sido esboçado. Desde o momento em que Raimundo Silva realiza a intervenção no texto historiográfico, referente à tomada de Lisboa, permitindo, assim, como se coloca no jogo narrativo, a permanência dos mouros na cidade, que ele se percebe como vítima de um cerco. A princípio, quando o revisor acaba de adulterar o texto histórico e perambula pelas ruas do bairro mouro de Lisboa, o agente ameaçador, pelo qual ele fantasiosamente se sente perseguido e cercado é o Costa, o diretor de produção da editora. Depois, quando de fato, se descobre o delito de Raimundo Silva é que ocorre o "cerco" dos outros diretores ao revisor, conforme descrito acima. Em ambos os casos, é pela voz desse personagem que os referidos confrontos são reconstituídos a partir do modelo de um cerco.

Mas, se nesses casos Raimundo Silva se coloca sempre como o elemento cercado, é o narrador heterodiegético que, ao definir a localização da casa do revisor, questiona a condição de sitiado ou sitiante do personagem. Ele acrescenta, ainda, que essa disposição incerta é que determinaria o futuro do revisor, conforme apresentado na seguinte citação: 
A menos de cinqüenta metros, embora invisível daqui, está a sua casa, e, ao pensá-lo, apercebe-se, pela primeira vez com evidência luminosa, de que mora no preciso lugar onde antigamente se abria a Porta de Alfofa, se da parte de dentro ou da parte de fora eis o que hoje não se pode averiguar e impede que saibamos, desde já, se Raimundo Silva é um sitiado ou um sitiante, vencedor futuro ou perdedor sem remédio. (SARAMAGO, 2004, p.75)

É interessante perceber, como já foi ressaltado anteriormente, que há uma sobreposição de tempos e vozes, como se os fatos referentes ao cerco histórico à cidade de Lisboa ecoassem no plano presente da narrativa. E se pensarmos a história como um processo contínuo, haverá, certamente, em alguma medida, uma intervenção do passado no presente. Mas, além disso, o que também se coloca, ao longo do romance, é a modificação do presente pela reconstituição historiográfica do passado, detonada pela intervenção transformadora do revisor Raimundo Silva. E, realmente, a história, à qual temos acesso, por exemplo, nas historiografias, não corresponde aos fatos históricos, mas sim ao relato desses fatos; e o arranjo discursivo dos fatos implica em uma escolha não arbitrária, que passa por critérios ideológicos relativos a uma determinada época e lugar de enunciação. Assim, entendemos que a intervenção no texto historiográfico exercida por Raimundo Silva, cujo alcance chega aos próprios fatos de sua atualidade, poderia corroborar um conceito de história que reconhece, em sua configuração, escolhas narrativas, culturais e até mesmo ficcionais.

Desse modo, o jogo estabelecido entre o "agora" de Raimundo Silva e o período histórico referente à tomada de Lisboa, poderia refletir as próprias confluências históricas, que ocorrem para além da linearidade cronológica. Certamente, esses pontos de convergência só podem ocorrer quando há alguma afinidade entre os contextos envolvidos. E, como vimos, os fatos pretéritos que contaminam o presente do protagonista da História do cerco de Lisboa são a presença dos mouros em Portugal e o 
cerco promovido pelos portugueses. Como também já foi indicado, esses dois fatos, que, na verdade, fazem parte de uma mesma situação, determinam tanto o modo como Raimundo Silva passa a perceber o seu entorno, como a própria constituição da trama narrativa. Nota-se, realmente, que a presença de uma alteridade inapreensível, desencadeada pela presença do invasor mouro, e a contraposição entre duas perspectivas alienadas, seguindo a configuração de um cerco, perpassam grande parte da elaboração narrativa.

Percebemos, como um exemplo bastante ousado dessa conjugação, por pressupor um considerável deslocamento significativo, a maneira como se articula, ao longo da narrativa, a relação entre a chefe dos editores, Maria Sara, e o Revisor Raimundo Silva, com as condições de alteridade e cerco, advindas do relato histórico. A narração da aproximação amorosa entre os dois personagens vai sendo sutilmente impregnada por metáforas e alusões às condições históricas referidas. A princípio, coloca-se apenas o misto de estranhamento e interesse de Raimundo Silva pela editora, o que poderia ser um leve indício do incômodo e curiosidade gerados por uma alteridade que não pode ser imediatamente compreendida. Um exemplo disso pode ser acompanhado, abaixo, na descrição referente à reação do revisor quando atenta, realmente, para a presença de Maria Sara:

Raimundo Silva, desconcertado, olhou-a [...] se o revisor estivesse mais perto poderia ver alguns fios brancos, e a boca é cheia, carnuda, mas os lábios não são grossos, estranho caso, um sinal de inquietação toca algures o corpo de Raimundo Silva, perturbação seria a palavra justa, agora deveríamos escolher o adjetivo adequado para acompanhá-la, por exemplo, sexual, porém não o faremos [...] (SARAMAGO, 2004, p.87)

No decorrer da narrativa, vai ficando mais patente a pertinência do modelo de alteridade, em sua vertente ameaçadora, para se configurar o temor de Raimundo 
Silva em relação a esse outro, imprevisto, que é Maria Sara. No seguinte trecho, quando a telefonista anuncia que vai completar uma ligação telefônica entre o revisor e sua chefe, ressalta-se, de fato, a marca do distanciamento que aliena as pessoas e ainda a consciência do risco envolvido na ação de se quebrar a distância:

\begin{abstract}
A telefonista disse, Vou ligar, é um anúncio corrente das telefonistas, lugar-comum da profissão, e contudo são palavras que prometem conseqüências, tanto para o bem como para o mal, Vou ligar, disse ela, indiferente ao destino que utiliza os seus serviços, e não repara que está a dizer, Vou juntar, apertar, prender, atar, liar, fixar, unir, aproximar, vincular, relacionar, associar, na sua idéia somente se trata de pôr em comunicação duas pessoas, mas esse mesmo simples ato, observemo-lo nós, já transporta consigo riscos mais do que suficientes para que não o cometêssemos com leviandade. Porém, não adiantam os avisos, apesar de a experiência nos demonstrar diariamente que cada palavra é um perigoso aprendiz de feiticeiro. (SARAMAGO, 2004, p.101)
\end{abstract}

Mas, além do tema de alteridade ser frequentemente aludido, em algumas de suas nuances significativas, também a estrutura de cerco, como já dissemos, perpassa a composição narrativa, como uma maneira de traduzir a arriscada interação entre os personagens. Particularmente no início da aproximação, Raimundo Silva é colocado na posição de sitiado enquanto Maria Sara é vista como o agente sitiante, conforme exposto no seguinte excerto. Isso, talvez, possa ser explicado pela grande afinidade apresentada, ao longo do romance, entre a voz do narrador e a do protagonista. Se em alguns momentos o narrador chega a demonstrar um conhecimento mais abrangente sobre os fatos, antecipando até acontecimentos que se realizarão posteriormente, em grande parte do texto, há uma coincidência entre as percepções do personagem Raimundo Silva e do narrador. Assim, é bastante natural que a impressão de estranhamento e a designação de uma alteridade ameaçadora sejam direcionados à Maria Sara, e que, por isso, também, ela seja vista como o elemento sitiante do cerco. 
A seguir, pode ser observado um exemplo desse embate, no qual, a perturbação do revisor ante a vista do livro por ele modificado conflui com uma sensação semelhante a essa, mas ocasionada pela presença de Maria Sara. Em posição defensiva, e visivelmente incomodado por um aspecto de sutil sensualidade na aparência da revisora, e pela evidência de sua própria ousadia, presentificada pela obra adulterada, Raimundo Silva foge desse "enfrentamento", para ele fascinante e arriscado:

[...] baixou os olhos, levando neles a imagem duma blusa de decote em bico, de cor que a sua perturbação o impediu de definir. Agora não tirava os olhos da mesa, fascinado, estava ali a História do Cerco de Lisboa, [...] Não queria continuar a olhar a capa provocadora, mas tãopouco desejava enfrentar-se com a doutora Maria Sara, que nesse momento estaria a fitá-lo impiedosamente, como outra cobra-capelo, pronta a lançar o último e definitivo bote. (SARAMAGO, 2004, p.105)

Mas, se antes o revisor tivera, apenas, um rompante de coragem ao introduzir uma negativa, que simbolicamente modificara o texto historiográfico sobre a tomada de Lisboa, alterando por isso, também, a realidade presente, é Maria Sara quem o impele a dar continuidade a essa ação, e reescrever sua própria história sobre o assunto. Verifica-se, novamente, no fragmento abaixo, o paralelismo entre a história referente ao cerco de Lisboa e a situação de cerco estabelecida entre Raimundo Silva e Maria Sara:

[...] Maria Sara disse, Pensarmos nós que estamos onde foi a cidade moura, e Raimundo Silva a fingir que não percebera a intenção, Sim, estamos, e ia tentar mudar de conversa, porém ela, Às vezes ponho me a imaginar como terá sido aquilo, as pessoas, as casas, a vida, e ele calado, obstinadamente calado agora, sentindo que a detestava como se detesta um invasor [...] (SARAMAGO, 2004, p.173)

Aqui, em um ambiente contaminado pela ressonância do passado mouro de Lisboa, a editora é, explicitamente, identificada com o invasor. Mas, se pensarmos na 
estrutura de cerco estabelecido entre mouros e cristãos, no episódio histórico, perceberemos uma inversão na equação que conjuga esse fato com a interação entre Raimundo Silva e Maria Sara. No primeiro caso, o elemento estrangeiro, invasor, considerado bárbaro, associado a uma alteridade cultural e religiosa hostil, é o mouro, e quem realiza o cerco são os portugueses, representantes da cultura e religião cristã. Já na conjunção entre os personagens, Maria Sara encerra tanto os atributos dos mouros, por sua alteridade ameaçadora, como dos portugueses, devido à condição de sitiante, enquanto Raimundo Silva é retratado como sitiado. Assim, pode-se dizer que ocorre a apropriação das acepções de cerco e alteridade retiradas do episódio histórico referido, sem, entretanto, se estabelecer uma correspondência analógica entre as partes antagônicas envolvidas em cada um dos conflitos. Mas, nessa assimetria, poder-se-ia, também, identificar uma disposição que corrobora o modo como a polarização entre mouros e portugueses é desconstruída ao longo do romance. Pois, como foi apresentado no tópico IV.1.1, as motivações culturais e religiosas que subsidiam o antagonismo entre cristãos e muçulmanos, participantes do cerco, são esvaziadas por demonstrações irônicas de sua inconsistência e arbitrariedade. Assim, da mesma forma que a narrativa expõe a ausência de um lastro que justifique a oposição entre mouros e portugueses, a identificação precisa de Maria Sara e Raimundo Silva com cada uma dessas culturas seria incoerente, visto que, entre elas mesmas, não se define uma delimitação específica.

Mas, se a presença moura em Lisboa, no referido contexto histórico, estabelece uma relação de contiguidade com a tensão persistente entre Raimundo Silva e Maria Sara, a narrativa apresenta, ainda, conforme exposto abaixo, um provérbio popular referente aos mouros, que nos parece bastante significativo para se ampliar o alcance dessa associação: 
...é possível que a senhora Maria tenha dito, Há mouro na costa, expressão histórica e popular duma substancial desconfiança originada nos tempos em que os mouros, já então varridos da terra portuguesa, vinham assolar as nossas costas e vilas marinheiras, e hoje reduzidas a mera reminiscência retórica, porém de alguma utilidade, como acaba de ver-se. (SARAMAGO, 2004, p.217)

Percebe-se, a partir disso, que a figura do mouro, sempre associada ao perigo iminente, está tão entranhada no referencial luso que, mesmo se desvinculando da significação histórica, atua, ainda, no discurso popular, como uma "reminiscência retórica", representativa da desconfiança em relação ao desconhecido, qualquer que seja ele.

De fato, a expressão amplamente conhecida no contexto português, "Há mouro na costa", toma, simbolicamente, a figura do mouro, para expressar a suspeita sobre algum acontecimento. Mas, o âmbito específico, no qual, comumente, se utiliza esse provérbio, refere-se, mesmo, à suposição de uma ligação amorosa não anunciada. No excerto acima, a máxima é dita pela senhora Maria, quando ela imagina que Raimundo Silva tenha um envolvimento afetivo com alguém. Observa-se, assim, que, de algum modo, o lugar ocupado pelo mouro no imaginário português viabiliza a constituição metafórica de um dito popular referente à probabilidade de um contexto passional. A presença do mouro seria, nessa conjunção, a confirmação de uma relação amorosa.

No tópico I.1, já havíamos ressaltado o lugar significativo das relações amorosas entre mouros e portugueses na composição folclórica e lendária da cultura lusitana. Mas, o que nos chama a atenção no provérbio acima e, de maneira geral, no romance História do cerco de Lisboa como um todo, é a transição de um evento histórico, no qual a presença moura é o fato central, para uma situação pessoal, atemporal, concernente à possibilidade de uma ligação amorosa. 
No entanto, essa trajetória iniciada no âmbito histórico e que conduz, pelas tessituras narrativas, à conjunção amorosa, sofre, ainda, outro espelhamento que, pela perspectiva de Raimundo Silva e Maria Sara, retoma a história do cerco, mas, agora, em uma abordagem pessoal, afetiva, acerca de Mogueime e Ouroana. Pela influência de Maria Sara, o revisor compõe sua obra sobre a tomada de Lisboa, e, certamente, ainda por causa da editora, ele concebe esses personagens. Tal par amoroso, que é representativo de uma especificidade histórica, viabiliza a articulação entre dois contextos culturais. Como visto anteriormente, o narrador propõe que as divergências entre os padrões culturais se constituem ao longo da história, por isso, a presença de Mogueime e Ouroana, apartados em oito séculos de Raimundo Silva e Maria Sara, suscitam interessantes investigações sobre o componente cultural das relações amorosas. A seguir, na descrição sobre o primeiro contato entre os dois personagens, na obra de Raimundo Silva, pode-se acompanhar um exemplo desse tipo de reflexão:

\begin{abstract}
A mulher vira ligeiramente a cabeça para a esquerda como para escutar melhor o apelo, e estando Mogueime desse lado, um pouco para trás, teria sido impossível não se encontrarem os olhos dele com os olhos dela. Todo o desejo físico de Mogueime se apagou num ápice, apenas o coração se desatou aos saltos numa espécie de pânico, é difícil levar mais longe o exame da situação porque há que ter em conta o primitivismo dos tempos e dos sentimentos, corre-se sempre o risco do anacronismo, [...] inventar sutilezas de erotismo requintado em corpos que se contentam com ir direitos ao fim começando rapidamente pelo princípio. (SARAMAGO, 2004, p.227)
\end{abstract}

E, em um momento, apresenta-se, claramente, o desejo, como sendo o único aspecto de uma interação amorosa isento de condicionamentos culturais que se modificam ao longo do tempo: 
Pergunta-se agora Raimundo Silva que semelhanças há entre este imaginado quadro e a sua relação com Maria Sara [...] supomos que de comum haja apenas o desejo, que tanto o sentia o Mogueime daquele tempo como o está sentindo o Raimundo Silva de agora, as diferenças, que as há, são culturais, sim senhor. (SARAMAGO, 2004, p.246)

Seguindo o paralelismo estabelecido entre as duas histórias a aproximação entre Mogueime e Ouroana afeta ou é afetada pela aproximação entre Raimundo Silva e Maria Sara. A relação de causalidade é bastante ambígua, em alguns momentos, a formação do casal Ouroana e Mogueime parece viabilizar a constituição do outro par, mas aquele casal é um produto da imaginação de Raimundo Silva e, de alguma forma, também, um reflexo de suas próprias experiências e sensações.

Um pouco além desse ponto, quando, no entranhado jogo ficcional, a aproximação entre Maria Sara e Raimundo Silva se estabelece, de fato, uma questão que vinha sendo prenunciada ao longo do romance é finalmente colocada de forma inequívoca, como se pode verificar no diálogo abaixo:

Parece que estamos em guerra, Claro que estamos em guerra, e é guerra de sítio, cada um de nós cerca o outro e é cercado por ele, queremos deitar abaixo os muros do outro e continuar com os nossos, o amor será não haver mais barreiras, o amor é o fim do cerco. (SARAMAGO, 2004, p.330)

O que antes era sugerido apenas pela perspectiva de Raimundo Silva e de um narrador muito próximo a ele e, por isso, apresentado de forma parcial, revela-se agora de modo mais claro e abrangente sob a perspectiva de Maria Sara. Ou seja, o que era para o revisor a representação de uma alteridade incompreensível e ameaçadora, pela qual ele se sentia sitiado, agora, devido a proximidade amorosa, torna-se humanizado e ganhe voz própria. E é através da fala da Maria Sara que ele toma conhecimento da reciprocidade implicada no cerco estabelecido entre eles: ambos 
seriam ao mesmo tempo sitiados e sitiantes.

Mas, a última frase da narrativa desfaz o tom harmônico e conclusivo que antes se apresentara pela união entre Maria Sara e Raimundo Silva, abrindo-se uma perspectiva enigmática: "Não adormeceram logo. Sob o alpendre da varanda respirava uma sombra”. (SARAMAGO, 2004, p.348). Talvez, possa se apreender daí a sugestão de uma ameaça velada e permanente. Ou, retomando aquele episódio no qual Raimundo Silva vê uma cigana, mas enxerga uma moura, “[...] Mas o cerco não acabou, avisam os olhos da cigana." (SARAMAGO, 2004, p.73). O desfecho inusitado parece mesmo sugerir a permanência do estado de cerco, ou seja, o armistício, ou o enlace amoroso, seria uma situação provisória e precária. A sombra representaria, assim, o lado obscuro, ainda estranho e ameaçador do outro, que nunca pode ser totalmente desvendado. 


\section{IV.2 - É isto um homem?}

\section{IV.2.1 - Introdução}

O título dessa tese provém de um diálogo contido na obra de Mário de Carvalho, Um deus passeando pela brisa da tarde, no qual se discute a invasão dos mouros a uma província da Lusitânia. Um dos personagens, ao refletir sobre a origem desses invasores, faz a seguinte colocação: “Tudo a mesma gente: púnicos, mouros... Farinha do mesmo saco. O lado errado do Marenostro.” (CARVALHO, 1997, p.23).

O referido romance de Mário de Carvalho foi publicado pela primeira vez em 1994, sendo contemplado, no ano seguinte, com o Grande Prêmio da Associação Portuguesa de Escritores. Observa-se nessa obra a abordagem histórica, concernente ao II século da Era Cristã, em uma província da Lusitânia, de nome Tarcisis. O caráter histórico da narrativa, entretanto, fica comprometido desde o início do texto, quando se lê uma advertência sobre a inexistência histórica de Tarcisis e a consequente inadequação de Um deus passeando pela brisa da tarde à categoria de romance histórico. Mas, acompanhando o discurso em primeira pessoa constituído por Lúcio Valério Quíncio, protagonista do romance, depreendemos, em diversos momentos, uma correspondência factual condizente com os relatos históricos oficiais.

O contexto inicial da obra de Carvalho retrata a condição de desterrado em que se encontrava o duúnviro, Lúcio, no momento em que decide escrever um livro sobre os acontecimentos ocorridos durante sua segunda magistratura. O elemento motivador para essa iniciativa, também aí contemplado, origina-se da visita de 
Proserpino, outro magistrado de Tarcisis, à villa na qual se refugiaram Lúcio e sua esposa Mara. A presença do antigo colega desperta no anfitrião lembranças de acontecimentos dolorosos, por ele vivenciados. Mesmo que Proserpino, em atitude inesperada, não tivesse mencionado nenhum fato pretérito que pudesse causar constrangimentos, sua simples presença parece ter significado para Lúcio uma referência metonímica representativa de todo o seu passado. A emergência incômoda de recordações ainda pouco remotas para o protagonista ocasiona, dessa forma, a necessidade de sua reconstituição memorial, através da escrita, como se observa nas seguintes palavras de Lúcio: "Pode ser que, escrevendo, se me apazigue o espírito, com manifesta utilidade para mim." (CARVALHO, 1997, p.26)

Situações, relativas aos âmbitos público e privado, vivenciadas por Lúcio, confluirão ocasionando o já mencionado desterro final do personagem. Os principais problemas políticos enfrentados por ele referem-se à presença de uma nova seita religiosa em Tarcisis - o cristianismo - e à possibilidade de um ataque mouro à cidade. Paralelamente a estas questões de ordem pública, Lúcio expõe-se a um conflito pessoal ainda mais intenso: a atração inevitável sentida por Iunia Cantaber, representante fervorosa do cristianismo, religião ainda incipiente na Lusitânia, causadora de escândalo e revolta aos cidadãos de sua cidade.

Acompanha-se, então, ao longo da narrativa, o encaminhar-se do protagonista para um completo isolamento em relação ao povo de Tarcisis, assim como, aos outros magistrados e, até mesmo, ao poder supremo de Roma, representado por Marco Aurélio Antonino. Também contribuem para o insucesso de Lúcio seus valores e gostos pessoais, bastante afinados com a cultura literária grega e latina, e totalmente dissonantes em relação aos jogos e espetáculos violentos que entretinham a plebe. 
Quando, finalmente, ocorre o cerco dos mouros à Tarcisis, a imagem pública de Lúcio já está bastante desgastada, e quem se configura como o grande herói da situação, salvando inclusive a vida do duúnviro, é seu inimigo Rufo Cardílio. Com a partida dos chamados povos bárbaros, retomam-se as atividades rotineiras da cidade, reorganizando-se um evento que havia sido suspenso devido à situação de instabilidade enfrentada: o julgamento dos cristãos. As conjunturas fazem com que o protagonista seja obrigado a proceder ao julgamento dos religiosos, e a declarar a pena máxima a Iunia Cantaber, o que provavelmente resultaria em sua morte. Segue-se, ainda, o último e fatal abalo à vida pública de Lúcio: a condenação ao exílio.

É a partir dessa ambientação tão singular, e já em si mesma conflituosa, que Lúcio Valério Quíncio, exilado em uma propriedade rural, elabora sua narrativa memorial. Através de sua história, ele vai trançando uma rede de questões políticas, religiosas e éticas, seguindo sempre uma lógica opositora entre a aparente sensação coletiva de segurança e estabilidade, gerada pela crença em um Império indestrutível, e os reais conflitos e angústias individuais daqueles que, devido às suas insatisfações pessoais, desafiam o que ele chama de "esta mediocridade dourada" (CARVALHO, 1997, p.13).

Os eventos, assim dispostos, pretendem apenas reapresentar a sequência cronológica da narrativa de Um deus passeando pela brisa da tarde, realçando algumas questões factuais que se articulam, ocasionando o desafortunado destino cumprido por Lúcio Quíncio. A sutil complexidade do romance constitui-se, entretanto, nos interstícios dos fatos aí retratados.

O próprio período histórico abordado, segundo século da Era Cristã, apresenta, a partir de uma perspectiva arguta, presente à elaboração narrativa, uma 
amostragem interessante de padrões políticos, religiosos, filosóficos e sociais. A imbricação entre paganismo greco-romano, cristianismo, tragicidade e estoicismo, coloca em pauta complexas dicotomias como: indivíduo e coletividade, o homem e a ordem, nómos (lei) e physis (natureza), civilização e barbárie.

Embora em todas essas relações possamos perceber afinidades com a nossa tese, interessa-nos, mais especificamente, o último par, aparentemente antitético, mas a respeito do qual tentaremos demonstrar a existência de uma relação associativa e inclusiva. Ou seja, o que normalmente é entendido como uma bipolaridade, civilização e barbárie, parece apresentar-se, a partir da presença do elemento mouro em Um deus passeando pela brisa da tarde, como uma situação de interdependência: a barbárie como estrutura intrínseca e necessária ao processo civilizatório romano.

Acompanha-se, no enunciado do romance como um todo, a generalização no tratamento do outro, ou daqueles que não pertencem ao Império Romano: os chamados povos bárbaros. Essa redução da diversidade de alteridades a uma denominação única - bárbaros - pode ser identificada com aquela concepção, proveniente da antiguidade grega, que considerava bárbaros os povos que não falassem grego. Apreende-se, então, ao longo da narrativa que, para os habitantes da Lusitânia, a atribuição da barbárie aos invasores mouros origina-se dos parâmetros civilizacionais atribuídos à romanidade, os quais reduzem a diversidade dos povos não romanos a uma massa uniforme, considerada apenas pela sua diferença em relação ao Império.

Coloca-se, de fato, no romance de Mário de Carvalho uma contraposição entre os mouros invasores e os lusitanos romanos, na qual se expressa uma concepção bastante cristalizada daqueles povos, revelada, de modo mais contundente, através da expressão, anteriormente mencionada: "O lado errado do Marenostro." (CARVALHO, 
1997, p.23). Mas, esse tipo de generalização, feita por um dos personagens, Proserpino, e representativa, também, do pensamento geral dos cidadãos de Tarcisis, mostra-se frágil e imprecisa quando comparada a algumas reflexões, subjacentes à narrativa conduzida pelo protagonista, Lúcio Valério Quíncio, ao contemplar a descrição do ataque mouro à região da Lusitânia.

Se podemos, pois, acompanhar, ao longo do romance, uma interessante discussão relativa à identificação do mouro como bárbaro, devido à divergência entre sua (falta de) cultura e a cultura romana, da qual faz parte o narrador, há, ainda, outra questão, menos explícita, que acaba, também, sendo sugerida no enunciado da obra: a similaridade existente entre as práticas romanas e os rituais bárbaros. Em diversos momentos, a trama conduz a reflexões sobre uma "cultura bárbara" amplamente difundida e aceita no Império Romano, em suas arenas de gladiadores, no sacrifício dos condenados jogados aos cães, enfim, nos espetáculos sangrentos que entretinham o povo.

Mas, para além da barbárie associada ao invasor mouro, apresentado como uma alteridade inapreensível e, ainda, daquele contexto, vinculado às práticas violentas exercidas no interior do Império Romano, emerge, também, do discurso de Lúcio, outra expressão referente ao âmbito da barbárie. Identificamos, pois, como uma inusitada “invasão bárbara”, o sentimento passional de Lúcio por Iunia Cantaber, sendo esta expressão ainda mais devastadora, pois chega a alcançar e desestruturar, até mesmo, as defesas pessoais do protagonista, então sustentadas pela racionalidade e moderação estóicas e pelo sentido de civilidade romana.

Apresentaremos, a seguir, mais detalhadamente, cada uma das três referidas elaborações acerca da temática da barbárie, motivadas pela presença moura no discurso 
memorial de Lúcio Valério Quíncio.

\section{IV.2.2 - É isto um mouro?}

O capítulo IX da obra de Mário de Carvalho inicia-se de forma um tanto abrupta com a seguinte frase: "É isto um mouro?" (CARVALHO, 1997, p.141). A inversão do sentido natural da frase, com o deslocamento do verbo para o seu início, a utilização do pronome isto, determinando a reificação do mouro, e, ainda, o tom interrogativo da sentença remetem, sem dúvida, ao título da obra de Primo Levi, É isto um homem?. A narrativa de Levi contempla, entretanto, a experiência, em campos de concentração, vivida pelo autor, um judeu italiano, durante a Segunda Guerra mundial. Mas, há um ponto bem evidente, entre outras questões mais sutis, que discutiremos adiante, que parece indicar, de fato, a relação entre as obras. Como se pode acompanhar abaixo, a seguinte citação apresenta uma colocação bastante cruel sobre o chamado prisioneiro "muçulmano":

No Campo, porém, acontece o contrário. Aqui a luta pela sobrevivência é sem remissão, porque cada qual está só, desesperadamente, cruelmente só. Se um Null Achtzehn vacila, não encontrará quem lhe dê ajuda, e sim quem o derrube de uma vez, porque ninguém tem interesse em que um "muçulmano" a mais se arraste a cada dia até o trabalho; (LEVI, 1988, p. 89)

Em nota de rodapé, o autor explica que o termo alemão muselmann, cujo significado é muçulmano, era usado pelos veteranos do campo de concentração para 
designar os prisioneiros mais fracos. A partir daí, muitas outras vezes, o narrador utiliza esse mesmo vocábulo para se referir aos presos destituídos de qualquer proteção e ineptos para a sobrevivência no Campo. É nesse contexto que percebemos a interseção mais óbvia entre a narrativa de Primo Levi e o romance de Mário de Carvalho. Se na obra de Levi, o termo "muçulmano", totalmente desvinculado de seu significado dicionarizado, referente aos seguidores de Maomé, funciona como designação pejorativa daqueles que ocupavam os lugares mais baixos na peculiar hierarquia de Auschwitz, em Um deus passeando pela brisa da tarde, como já foi comentado, parece decorrer de uma postura arbitrária a identificação dos mouros como bárbaros. Como dissemos, no período histórico aí retratado, não existia ainda a religião muçulmana, e o cristianismo era apenas incipiente, mas, mesmo assim, sem a usual justificativa religiosa, o elemento mouro é eleito representante da alteridade bárbara, que ameaça a estabilidade da Lusitânia romana.

É claro que, diferentemente do completo deslocamento significativo do termo "muçulmano", em É isto um homem?, no romance de Mário de Carvalho, a denominação de mouros, dada aos invasores, está atrelada, de fato, à origem étnica desses povos. O que tentamos ressaltar, no entanto, é que em ambos os casos a contemplação do mouro e do muçulmano decorre de uma escolha deliberada desses elementos como representativos de uma alteridade impessoal, objetivada, reificada.

$\mathrm{Na}$ narrativa de Um deus passeando pela brisa da tarde, os invasores poderiam ser quaisquer outros estrangeiros, como os púnicos, também referenciados na obra, mas é apenas o elemento mouro, provavelmente por seu papel significativo, no posterior desenrolar histórico da cultura portuguesa, que assume esse lugar. Já o texto de Levi reflete a realidade do campo de extermínio nazista, onde um linguajar próprio é 
constituído, juntamente com um conjunto de padrões sociais específicos desse microcosmo. E, embora a narrativa não apresente explicações relativas a essa inusitada denominação, que identifica os judeus com terminologia designativa de seus inimigos históricos, essa atitude expressa, sem dúvida, uma preconceituosa ironia, pois são justamente os prisioneiros, em situação mais precária, que são designados, como "muçulmanos".

O seguinte excerto apresenta, de maneira impressionante, o esvaziamento de qualquer vestígio de humanidade nos chamados “muçulmanos":

\begin{abstract}
A sua vida é curta, mas seu número é imenso; são eles, os "muçulmanos", os submersos, são eles a força do Campo: a multidão anônima, continuamente renovada e sempre igual, dos não-homens que marcham e se esforçam em silêncio; já se apagou neles a centelha divina, já estão tão vazios, que nem podem realmente sofrer. Hesita-se em chamá-los vivos; hesita-se em chamar "morte" à sua morte, que eles já nem temem, porque estão esgotados demais para poder compreendê-la. (LEVI, 1988, p. 91)
\end{abstract}

Aqui, o narrador que vivencia e também observa atentamente a barbárie imposta no Campo de Concentração, elabora, então, o que nos parece ser a consequência mais brutal da situação: a formação de uma "multidão de não-homens", que sequer pode sofrer, pois esse sentimento implica um traço da interioridade humana que eles já não possuem. Uma diversificada gama de violência, determinante da exaustão física, emocional e psicológica, justificaria, nesse relato, a alienação e desumanização de toda essa coletividade "muçulmana".

Prosseguindo, então, a analogia, anteriormente sugerida, entre os "muçulmanos" de Auschwitz e os mouros invasores da Lusitânia, estabeleceremos um paralelo, entre a citação acima, referente à multidão desumanizada descrita por Levi, e os seguintes trechos do romance de Mário de Carvalho: 
Nada que se parecesse com uma ordem de batalha ou uma legião em marcha. Aparentavam antes uma revoada de insectos, amolecida pelo calor, perdidas as asas, dispersando-se cautelosamente na altura em que se lhes arrasa o ninho. Arrastavam-se indivíduos e grupos dispersos, uns carregando fardos, outros eriçados de armas rudimentares, outros trazendo o seu jumento, alguns a cavalo, a grande maioria a pé, pouquíssimos de carro. Não havia ali vanguarda nem retaguarda, nem vélites nem impedimenta. Era uma massa, dispersa, à toa, pela charneca fora. E mostravam-se tão escuros $\mathrm{e}$ pobres os seus trajos que pareciam nascidos da terra e comungar da mesma constituição dos matos e tojos secos que pisavam. (CARVALHO, 1997, p.221)

Este excerto é parte do relato feito por Lúcio, quando vê, pela primeira vez, os mouros aproximando-se das muralhas da cidade. Nota-se que a pobreza e desorganização dos invasores, comparativamente às legiões romanas, foi o que mais lhe chamou a atenção, comparando-os, por isso, a um agrupamento de insetos ou a uma massa disforme constituída por elementos telúricos.

De forma análoga, o informante Airhan parece visualizar os mouros de um modo tão generalizante e superficial que, em sua descrição sobre esses povos, chega a compará-los às nuvens de gafanhotos:

[...] Airhan comparava-os às nuvens de gafanhotos que em anos de praga fazem o mesmo percurso por sobre as ondas, revoada após revoada. E assim como esses animais depredam e deixam rasos de verdura os campos, assim estes invasores vinham para talar, por círculos mais e mais vastos, as fazendas e as vidas em redor. E as suas mandíbulas eram rudes armas de pedra e osso e o sinal da sua passagem a devastação dos fogos. (CARVALHO, 1997, p.55)

Nas duas citações acima, a desumanização do mouro constitui-se através dos discursos de Lúcio e Airhan, ao valerem-se de analogias feitas aos insetos para descreverem esse povo. Já o seguinte fragmento, apresenta não mais o discurso, mas a própria ação de tratar o cadáver de um mouro como uma carcaça de animal, utilizada como objeto de exposição. Conforme descrito abaixo, os chamados rústicos, que seriam 
os cidadãos que habitavam os arredores de Tarcisis, mantinham o corpo do mouro coberto e só o mostravam àqueles que pagassem:

Os rústicos arrastavam os restos do mouro para que todos soubessem a notícia e os felicitassem e remunerassem condignamente pelo feito. Tencionavam continuar a exibi-lo, por todas as povoações em redor, arrecadando como recompensa o dinheiro que a generosidade dos cidadãos quisesse despender. Como costumam fazer com as carcaças dos lobos ou dos ursos [...] (CARVALHO, 1997, p.143)

A animalização e coisificação dos mouros, presentes nas citações acima, equiparam-se, de fato, à desumanização dos "muçulmanos" denunciada na obra de Primo Levi. Há, no entanto, um ponto fundamental que constitui uma inversão entre as duas constituições narrativas. O relato memorial composto por Lúcio apresenta a visão de um cidadão romano, que tem como parâmetros apenas os referenciais desse Império, como as legiões romanas, por ele citadas. A desumanização dos mouros, nesse caso, é forjada pelo discurso parcial do narrador que só consegue percebê-los através da sua diferença em relação a um modelo muito específico de civilização. Já no caso da obra de Levi, o narrador é também um prisioneiro do Campo de Concentração e por isso a sua percepção desse outro, reificado, não se constitui por nenhum tipo de distanciamento cultural, mas justamente pela assustadora e terrível proximidade entre eles. E esse triz que separa o humano do que já não pode mais ser considerado um homem é que motiva grande parte das reflexões apresentadas no texto.

A possibilidade de se encontrar uma marca de humanidade, de dignidade ou de civilização é perseguida obsessivamente ao longo da obra. Mas, como se pode acompanhar nas seguintes citações, ocorre uma oscilação entre o ponto de vista inicial, onde ainda persiste um impulso de resistência à barbárie e à desumanização, resultantes da absoluta hostilidade do Campo, e a perspectiva final, na qual se revela a 
inexorabilidade do esvaziamento humano ante uma experiência tão brutal:

[...] justamente porque o Campo é uma grande engrenagem para nos transformar em animais, não devemos nos transformar em animais; até num lugar como este, pode-se sobreviver, para relatar a verdade, para dar nosso depoimento; e, para viver, é essencial esforçar-nos por salvar ao menos a estrutura, a forma da civilização. (LEVI, 1988, p. 39)

A seguinte passagem refere-se a um momento posterior, em que os alemães já haviam abandonado o Campo e os prisioneiros, aos poucos, se davam conta da iminente liberdade. Como dissemos, nesse contexto final da narrativa, apresenta-se a confissão da experiência de completa animalização, vivenciada no Campo de Extermínio, desfazendo-se, assim, aquele tênue limite que separava a civilização da barbárie:

Jazíamos num mundo de mortos e de fantasmas. O último vestígio de civilização desaparecera ao redor e dentro de nós. A obra de embrutecimento empreendida pelos alemães triunfantes tinha sido levada ao seu término pelos alemães derrotados. É um homem quem mata, é um homem quem comete ou suporta injustiças; não é um homem que, perdida já toda reserva, compartilha a cama com um cadáver. Quem esperou que seu vizinho acabasse de morrer para tirarlhe um pedaço de pão, está mais longe (embora sem culpa) do modelo do homem pensante do que o pigmeu mais primitivo ou o sádico mais atroz. Uma parte de nossa existência está na alma de quem se aproxima de nós; por isso, não é humana a experiência de quem viveu dias nos quais o homem foi apenas uma coisa ante os olhos de outro homem. (LEVI, 1988, p. 173)

Nesta impressionante elaboração, relativa ao reconhecimento da condição primitiva, bárbara e animalesca a que chegaram os prisioneiros, constitui-se uma conclusão ainda mais surpreendente, que pode ser melhor apreendida na junção dos seguintes fragmentos: "É um homem quem mata, é um homem quem comete ou suporta injustiças" e "[...] não é humana a experiência de quem viveu dias nos quais o homem 
foi apenas uma coisa ante os olhos de outro homem." (LEVI, 1988, p. 173). Ou seja, a completa obra de barbarização humana, não se consuma nos atos de extrema violência sofridos ou praticados, mas na reificação do homem pelo homem. A incapacidade de reconhecimento da dimensão humana do outro é o que confere ao homem a verdadeira condição bárbara.

Esse pronunciamento - ainda mais legítimo por se tratar da perspectiva de um judeu, que sofreu as diversas formas de violência praticadas nos campos nazistas e que consegue perceber a desumanização naquilo que transcende os atos de brutalidade física, localizando-a na incapacidade de reconhecimento da alteridade - assemelha-se com uma concepção de barbárie processada por Francis Wolff. Para superar a falaciosa definição maniqueísta de civilização e barbárie e a improdutiva relativização desses termos, Wolf elabora a seguinte proposição:

Chamaremos de bárbara toda cultura que não disponha, em seu próprio cerne, de estruturas que lhe permitam admitir, assimilar ou reconhecer outra cultura - ou seja, a simples possibilidade de outra forma de humanidade. (WOLFF, 2004, p,41)

A construção abstrata e teórica de Wolf confirma, de algum modo, a percepção visceral de Primo Levi, revelada ao final de sua obra. O relato de Levi, entretanto, abarca o homem em sua individualidade, enquanto a dimensão retratada por Francis Wolf refere-se à cultura como um todo.

Assim, das elaborações de Primo Levi e Wolf, aqui expostas, concluímos que a barbárie poderia se configurar pela incapacidade de reconhecimento e aceitação da alteridade. Mas, a apreciação de Lúcio e de seus concidadãos, concernente aos mouros, revela, exatamente, a impossibilidade de uma mínima compreensão de sua humanidade. E, se por um lado, a expectativa de uma elaboração, relativa à interação 
entre alteridades culturais, ou a própria terminologia aí empregada, parece totalmente anacrônica para o contexto histórico contemplado no romance de Mário de Carvalho, por outro, a forma como a narrativa de Levi é aludida parece provocar, de forma bem consciente, esse tipo de reflexão. E, realmente, os fatos referentes à presença dos mouros em Tarcisis são ínfimos, o que ganha destaque no texto é, justamente, a percepção dos cidadãos em relação aos invasores.

Ocorre que, embora a abordagem temporal de Um deus passeando pela brisa da tarde apresente uma rigorosa reconstituição histórica, fiel aos ideários da época, permite, entretanto, que uma precisa articulação dos fatos históricos resulte em estruturas, bastante originais, capazes de alcançar diretamente o período de enunciação do romance: final do século XX. Dessa forma, sem quebrar as expectativas internas de verossimilhança, o texto de Mário de Carvalho consegue comunicar-se com a nossa atualidade propondo, de forma sutil, reflexões bastante perspicazes sobre assuntos complexos, como a questão da alteridade.

É interessante pensar que o referido romance de Mário de Carvalho, publicado em 1994, e cujo tempo ficcional corresponde ao II século da Era Cristã, eleja, como parte de sua temática, a presença dos mouros na região da Lusitânia. A peculiaridade da questão assenta-se sobre o fato de que nesse período, evidentemente, não existia, ainda, a religião muçulmana e, portanto, o conflito entre lusitanos e mouros não tinha o peso da motivação religiosa. E se, conforme apresentamos acima, há uma equalização desdenhosa dos estrangeiros, considerados como bárbaros, são apenas os mouros, aqueles que, de fato, são retratados na obra. Ou seja, se "o lado errado do Marenostro" é sempre o outro, o mouro poderia ser um representante dessa alteridade no imaginário português. Assim, poderíamos entrever, nessa obra de Mário de 
Carvalho, a sugestão de uma prevalência moura na cultura portuguesa que, para além dos fatos históricos e religiosos, alcançaria uma dimensão simbólica propícia para se designar o outro - bárbaro, invasor, exótico, diferente.

\section{IV.2.3 - A barbárie intrínseca à civilização romana}

Conforme colocado anteriormente, a presença do elemento mouro em $\mathrm{Um}$ deus passeando pela brisa da tarde possibilita outras reflexões, também profícuas, sobre a questão da barbárie. Neste tópico, trataremos do assunto, partindo da seguinte situação: ao mesmo tempo em que a narrativa apresenta o cerco dos bárbaros mouros a uma província da Lusitânia sob o domínio romano, no II século da Era Cristã, o narrador sugere a presença da barbárie no âmago, mesmo, desta sociedade.

Decorre daí uma relativização do conceito de bárbaro como aquele que vem de fora: a barbárie, associada ao gosto pela violência, é reconhecida nas práticas cotidianas dos cidadãos romanos. Atentamos para a inusitada configuração estabelecida na obra de Mário de Carvalho, que torna patente a disposição de representações bárbaras no âmago de um Império que, ironicamente, se vangloriava por seu alto grau de civilidade.

Mas, Lúcio, ao insinuar, em sua narrativa, a presença da barbárie localizada no interior da civilização romana, não o faz seguindo o viés da alteridade, como foi discutido no tópico anterior, mas considerando, especificamente, as práticas violentas 
exibidas de forma espetacular para um público completamente embevecido. A seguir apresentamos um fragmento do texto memorial de Lúcio Quíncio, no qual se pode acompanhar a descrição das práticas selvagens ocorridas nas arenas de gladiadores:

O gladiador musculado que entrava de braços levantados, entre clamores, saía daí a minutos arrastado pelos pés, depois de o crânio lhe ter sido rebentado com um malho pelos oficiais da arena, travestidos de Caronte. Dentro em breve, nesta ou noutra hora, o mesmo aconteceria ao que o tinha derrubado. "Dá-lhe", "degola", berravam os lorários saltitando em volta dos combatentes de chicote em riste. Hiante, a populaça acompanhava em coro: "Derruba", “fere!". (CARVALHO, 1997, p.178 - 179)

O discurso de Lúcio, longe de reproduzir o tom de exortação manifestado pelos outros cidadãos romanos que assistiam ao evento, parece conter um vislumbre de assombro e indignação ante a violência dos acontecimentos por ele presenciados e narrados. De fato, se observarmos uma colocação anterior do protagonista, referente ao mesmo evento, percebemos uma atitude crítica bem sutil, revelada em uma interessante formulação, que sobrepõe o sentido de barbárie, simbolizado pelo sangue derramado nestes eventos violentos, à civilidade romana, presentificada pelos perfumes:

Não sei se era impressão minha: parecia-me que, ao fim de algum tempo, o cheiro húmido, salgado, do sangue sobrelevava o odor dos perfumes preciosos que impregnavam a bancada em que nos sentávamos. (CARVALHO, 1997, p.177)

E, finalmente, no diálogo entre Lúcio e o imperador Marco Aurélio Antonino, o protagonista confessa a sua repugnância e incompreensão frente à carnificina praticada nas arenas. Mas, o imperador, admitindo que isso possa ser, de fato, considerado uma prática sacrificial humana, ressalta que, ainda assim, justifica-se como algo necessário para acalmar a ira do povo. O seguinte excerto apresenta o 
pronunciamento de Marco Aurélio dirigido a Lúcio, no qual fica evidente a defesa de uma "espetacularização da barbárie" para que se possa controlar a violência inerente à própria condição humana:

Olha que é falso que nós, Romanos, tenhamos acabado com os sacrifícios humanos. Apenas alteramos os procedimentos. O que proibimos aos povos submetidos são as suas formalidades peculiares de matar. E consideramo-los romanizados e felizes quando adotam os nossos ritos, que são estes. [...] Sabes? A sede de sangue é tão grande que, não podendo saciá-la nos anfiteatros, iriam saciá-la nas ruas. Se eu proibisse os espetáculos, voltaríamos talvez às guerras civis e às proscrições. Surgiriam outros césares. Devo correr esse risco? (CARVALHO, 1997, p.186)

Assim, as camadas populares de Tarcisis ou de Roma, a quem Lúcio se refere, com desprezo, como turba ou populacha, são sustentadas pela prática do "panis et circenses", , com ênfase à necessidade dos espetáculos violentos. Resulta, dessa conjuntura, uma forma de alienação popular astuciosamente aproveitada e promovida pelos governantes romanos. O tribuno Marco Agneio Scauro, representante do poder romano em Tarcisis, compartilha da visão da espetacularização da violência até mesmo nos procedimentos jurídicos, como o julgamento de Arsenna, um salteador capturado em Tarcisis, e dos seguidores fanáticos da nova religião, os cristãos. Em uma discussão com o duúnviro, na qual este recusa-se a aceitar a correspondência entre um julgamento e um espetáculo, Marco Scauro rebate:

\footnotetext{
${ }^{7} \mathrm{O}$ fato novo que caracterizou então a vida da plebe que vivia na cidade de Roma no tempo do Império foi a sua neutralização política (aquietação das insatisfações sociais, reivindicações e revoltas) dos pobres, por meio de subsídios alimentares e de diversões públicas. Os ricos, por sua vez, estavam privados das lutas políticas que haviam ocupado boa parte de seu tempo na época da República. No século II d.C, o estado fornecia trigo gratuitamente, todos os dias, a quase duzentas mil pessoas. Essa política ficou conhecida, como já vimos, como a do "pão e circo", em expressão cunhada pelo satirista latino Juvenal (50-130 d.C.) e servia basicamente para manter a população pobre da cidade sob controle, submissa. (FUNARI, 2001,p.114)
} 
Não achas? Não vai o povo assistir? Não se fazem apostas? Não há claques e entusiasmos? Não se comenta no fórum? Não é o assunto dominante de todas as especulações? Não pode preceder um segundo acto, que é o dos suplícios e execuções? Não exulta a plebe, de modo a ficar contente e grata? (CARVALHO, 1997, p.274)

A coerência dos argumentos de Scauro reflete, de fato, a estrutura alienante que predominava em todas as instâncias do Império. Verificamos, então, que as relações entre barbárie e civilização, nesse contexto, alcançam uma configuração bastante complexa. A barbárie, associada ao sentido de violência, é compreendida como uma necessidade inerente à condição humana. Mas, para impedir que atos de selvageria comprometam as estruturas civilizacionais romanas, são promovidos espetáculos brutais, nos quais sacrifícios humanos são praticados, em um contexto esportivo de lutas e jogos. Dessa forma, a ferocidade dos cidadãos fica circunscrita aos circos e arenas de gladiadores.

Mas, além do espaço específico, onde se promove uma barbárie controlada, várias manifestações que pareçam comprometer os estatutos civilizacionais romanos como o cristianismo, os mouros ou os bandidos - são juridicamente avaliadas, com todo o rigor das leis, para, então, serem eliminadas em sacrifícios festivos, também previstos nesses julgamentos. E, ordenando esse esquema de controle de criminalidade, através da prática circunscrita da violência, estão os governantes romanos, que, em posição bastante distanciada dos cidadãos comuns, não se comprazem desses espetáculos populares.

Assim, é o povo, de fato, que, alienado de sua capacidade de pensar, fazer escolhas, se revoltar, sendo, de certa forma, desumanizado, reproduz em sua relação com o outro, não-romano - o gladiador, o cristão, o mouro - uma prática de reificação. É do interior dessa massa homogênea, cuja civilidade é extraída de práticas bárbaras, 
que se constitui a perspectiva desumanizada do outro e a incapacidade de reconhecimento e aceitação da alteridade.

E, nesse contexto, as tão conhecidas palavras de Walter Benjamin tornam-se absolutamente precisas: "Nunca houve um monumento da cultura que não fosse também um monumento da barbárie." (BENJAMIN, 1985, p.225). Nessa obra da literatura portuguesa contemporânea, pode-se confirmar a máxima elaborada pelo filósofo alemão, que destitui a convencional dicotomia "civilização e barbárie" e reconhece a presença da barbárie como estrutura intrínseca ao processo civilizatório. A aparente oposição entre a civilização romana e os invasores bárbaros é redimensionada, em Um deus passeando pela brisa da tarde, por uma estruturação narrativa, que evidencia, através da presença dos mouros, as práticas violentas e intolerantes necessárias para se obter o precário efeito de civilidade.

\section{IV.2.4 - Iunia Cantaber: a ameaça interna}

Já no início da narrativa, quando Lúcio encontra-se exilado e reflete sobre os problemas enfrentados, que teriam determinado sua condição de desterrado, ele faz a seguinte colocação: "Ainda hoje olho com desconfiança quem venha do lado do Oceano. Mas será das praias que acorrem todos os perigos?” (CARVALHO, 1997, p.18). O perigo advindo do oceano são os mouros, mas uma condição fundamental para que Lúcio Valério perca sua posição de duúnviro e seja exilado de Tarcisis é o sentimento passional sentido por Iunia Cantaber, pois é isso o que compromete todas as 
decisões públicas tomadas por ele. Assim, esse outro perigo insinuado na reflexão do protagonista-narrador seria, certamente, uma alusão à Iunia. Desde o princípio do romance define-se, dessa forma, um paralelismo entre a configuração ameaçadora dos mouros e aquela representada por Iunia Cantaber.

Tal perspectiva é reforçada também, em determinado ponto da narrativa, no qual a própria Iunia explicita sua identificação com os mouros. Isso ocorre no capítulo IX do romance, quando Lúcio surpreende Iunia Cantaber na intenção de enterrar um mouro, que seria apenas jogado em um lixo, e ela justifica sua atitude dizendo: "Este homem era meu irmão" (CARVALHO, 1997, p.147). A colocação de Iunia refere-se ao sentido cristão de irmandade entre os homens, mas funciona, ainda, como mais um indício da contiguidade entre o ataque dos mouros à Tarcisis e o sentimento avassalador que Iunia provoca em Lúcio Quíncio.

A angústia de Lúcio em relação à Iunia Cantaber é, de fato, bastante semelhante àquela experimentada quando ocorre a invasão dos mouros, e assenta-se, em ambos os casos, na incompreensão referente aos fatos inusitados e incontroláveis. Conforme apresentado no seguinte excerto, Lúcio Quíncio desenvolve um questionamento tão obsessivo quanto ineficaz acerca das motivações dos mouros para agirem de forma, para ele, totalmente incoerente. Observa-se, ainda, em seu discurso, a crença um tanto pretensiosa de que o entendimento racional de tal situação poderia leválo ao seu controle e solução. Mas, utilizando os parâmetros civilizacionais romanos para refletir sobre a ação dos chamados bárbaros, Lúcio só pode perceber a desordem e incoerência da invasão moura: 
Mas que deu àquela gente bisonha, mesquinha e bruta, para deixar, ululante, os seus desertos, [...] e vir desabar sobre a Lusitânia em correrias de sangue, talando fazendas, casas e gentes? Que ímpeto foi aquele que algum deus obscuro e ressaibado lhes comunicou e que não perdoava madeira nem pedra, culpado nem inocente, livre nem escravo, e que trazia o único escopo de destruir e volver em deserto as cidades e os agros talentosamente erguidos por gerações que falam latim, cultuam os deuses e praticam o direito? Um exército conquistador pilha por turnos, poupa os vencidos, reconstrói as cidades, cobra o tributo, restabelece a ordem. [...] Mas, quando passa uma horda, deixa na terra a marca da pura irracionalidade, o restabelecimento do caos original [...] Por quê? Em nome de quê? Se tal eu soubesse, seria o mais sábio dos homens e poderia aconselhá-los com proveito. $\mathrm{O}$ por quê daquela ânsia dementada de destruir deve ser, de todos o mistério mais bem guardado. Não quis a divindade revelar-mo, apenas que lhe sofresse as conseqüências. (CARVALHO, 1997, p. 16 - 17)

E, a persistente situação de incômodo causada pelo sentimento inexplicável nutrido por Iunia causa, no protagonista, sensações semelhantes a essas. A impossibilidade comunicação com esse outro estranho, incompreensível, impenetrável, representado por Iunia Cantaber, revela-se, repetidamente, no discurso angustiado de Lúcio Quíncio, como se pode verificar nas seguintes colocações: "Mas Iunia era um templo sem portas. Eu não conseguia descobrir nenhum acesso.” (CARVALHO, 1997, p.163). Ou, um pouco adiante, em um trecho no qual se coloca o esvaziamento da própria humanidade de Iunia:

Impunha-se-me como que um obsidiante desafio de conseguir chegar a Iunia, à verdadeira Iunia, à humanidade de Iunia, por detrás daquele enleio espesso de frases e atitudes. [...] Ambos estávamos iludidos sobre a vulnerabilidade do outro. Ela, porque não era pela sua piedade insólita que me tocava. Eu, porque sondava atrás das defesas de Iunia, onde, se calhar, não existia mais nada [...] (CARVALHO, 1997, p.166)

A incomunicabilidade entre Lúcio e Iunia parece mesmo estabelecer um distanciamento tão absoluto entre eles, quanto aquele apresentado pelo protagonista em relação aos mouros, como se pode depreender do seguinte fragmento: 
E à alma de Iunia, seria possível aceder? Obter um sinal qualquer mesmo mínimo que significasse: olho-te, vejo-te, reconheço-te, compreendo-te? Eu não exigia mais que um momento em que as nossas palavras, em vez de se entrechocarem e enovelarem em linhas dispersas, eriçadas de asperezas, conseguissem convergir [...] (CARVALHO, 1997, p.170)

A aproximação entre o imperador-filósofo Marco Aurélio Antonino e Lúcio Quíncio, reveladora de uma perspectiva estóica, também presente no discurso do personagem-narrador, parece ser desconstituída à medida em que ele se deixa dominar pela intensa e inexplicável atração exercida por Iunia Cantaber. Os preceitos estoicistas ${ }^{8}$ de controle sobre as paixões e de retidão cívica e moral tornam-se incongruentes em relação às suas atitudes, pautadas, então, pelo desejo de se aproximar de Iunia e no intento de protegê-la da ira popular. O mundo civilizado, estóico e comedido de Lúcio é então invadido por um sentimento estranho, passional e excessivo.

Parece haver uma sobreposição de pontos de vista presentes ao texto de Lúcio, os quais refletem, às vezes de forma indissociável, o momento de rememoração dos fatos e o tempo pretérito em que eles foram vivenciados. Se algumas questões relativas a sua atuação política e ao convívio com os outros magistrados puderam ser revistas de forma mais comedida e lógica, ao recordar os sentimentos experimentados por Iunia, entretanto, nota-se que a perspectiva do narrador permanece inalterada, imune a qualquer reflexão ordenadora. Além de não conseguir nomear, claramente, as sensações arrebatadoras que lhe causara Iunia Cantaber, Lúcio apresenta, em sua elaboração memorial, uma atitude, ainda, perplexa e desconcertada.

\footnotetext{
${ }^{8}$ Lúcio, sendo contemporâneo de Marco Aurélio, pertenceria, cronologicamente, ao terceiro período do estoicismo romano, chamado estoicismo imperial ou novo estoicismo, representado, também, por Sêneca e Epicteto, entre outros. O item cinco, do livro V dos Pensamentos de Marco Aurélio, proporciona, de forma simplificada, uma noção geral dos aconselhamentos morais e regras de conduta representativos deste período da filosofia estóica: Faz-te a elas então, pois que dependem absolutamente de ti: sinceridade, gravidade, poder de agüentar, continência, aceitação do destino, moderação dos desejos, benevolência, liberdade, simplicidade, seriedade nos propósitos, grandeza de alma. (MARCO AURÉLIO, 1971, p.51)
} 
Embora menos óbvio que os dois primeiros exemplos de barbárie, concernentes ao estrangeiro invasor e à violência romana, apontados anteriormente, a forma como Lúcio é afetado por Iunia e, ainda, a sua incompreensão frente a esse sentimento fazem com que o narrador a conceba como um elemento estranho, representativo de grande ameaça aos valores que lhe pareciam mais consistentes.

A contiguidade entre a maneira como o narrador autodiegético descreve sua interação com Iunia Cantaber e a barbárie em um contexto lato, advindo principalmente do sentido de alteridade estranha e ameaçadora, parece ter sido viabilizada, exatamente, pelas referências ao invasor mouro, contidas no discurso memorial de Lúcio. O modo como são pensados os mouros ou, mais precisamente, a dificuldade de apreensão desses povos, identificados como bárbaros, parece ter contaminado a estruturação narrativa e a percepção geral de Lúcio sobre toda a realidade a sua volta. Assim, de forma inconsciente, o narrador aparenta mimetizar, em suas preleções sobre Iunia Cantaber, as mesmas estruturas utilizadas para elaborar a relação de adversidade e alteridade referente aos mouros. 


\section{IV.3 - Conclusão}

Concluímos assim que, a temática histórica concernente ao mouro desencadeia a discussão de temas bastante semelhantes nas narrativas de História do cerco de Lisboa e Um deus passeando pela brisa da tarde. A percepção dos portugueses, no romance de José Saramago, ou dos lusitanos romanos, na obra de Mário de Carvalho, que identifica os mouros como bárbaros, revela, na verdade, deficiências de apreensão da alteridade cultural. Assim, a representação do mouro, identificado como bárbaro, deflagra, ainda, reflexões sobre a barbárie, principalmente nos sentidos de violência e intolerância, inerente à própria cultura.

Acompanhamos, também, nos dois romances, que a figuração do mouro, associada à alteridade e diversidade, enforma outro discurso, referente às relações pessoais, considerando-se para isso os sentidos de estranhamento e temor implicados nos dois contextos. A configuração apresentada em História do cerco de Lisboa, na qual, circunstâncias históricas acerca da presença dos mouros em Portugal são utilizadas como estrutura para se pensar o relacionamento amoroso entre Maria Sara e Raimundo Silva, assemelha-se àquela encontrada na obra de Mário de Carvalho. Também aí, a presença do mouro, percebido como elemento estranho e ameaçador da ordem, parece funcionar como um subsídio para Lúcio Quíncio estruturar o inusitado sentimento passional provocado pela presença de Iunia Cantaber.

No romance de José Saramago, entretanto, o modelo de cerco, utilizado para retratar a interação entre o revisor e sua chefe, funciona como uma estrutura que permite o intercâmbio entre o elemento sitiado e o sitiante. Assim, em configurações de acesso 
diversas, nas quais interagem Raimundo Silva e Maria Sara, viabiliza-se o encontro amoroso entre os personagens.

Já em Um deus passeando pela brisa da tarde, a condição passional estabelecida entre Lúcio e Iunia expressa a desigualdade e assimetria implicadas, também, na situação de invasão referente aos mouros. De fato, entre Iunia Cantaber e Lúcio Valério Quíncio se estabelece uma ação invasiva, aniquiladora, de sentido único, que impossibilita qualquer forma de interação. Como foi visto, a total inacessibilidade e incomunicabilidade entre os personagens prevalece até o final da narrativa, quando Lúcio reafirma a absoluta estranheza e incompreensão ainda motivados pela presença de Iunia em seu passado. 


\section{CONCLUSÃO}

Se a história oficial retratou, de modo geral, os grandes monumentos da civilização, a literatura parece representar, com frequiência, um espaço privilegiado para se refletir sobre tudo aquilo que foi recalcado e rejeitado por essa perspectiva limitadora. Conforme foi visto, paralelamente ao universo histórico, ficcional e simbólico, relativo à figuração do mouro, em algumas obras aqui destacadas, observamos, também, reflexões bastante profícuas em torno de uma caracterização bárbara dos próprios portugueses ou, em um sentido mais amplo, daquilo que é considerado civilizado.

O chamado bárbaro mouro desencadeia, assim, considerações referentes à barbárie prevalente no interior da cultura ou da civilização. Nesse sentido, a endogenia apontada na obra de Alexandre Herculano pode ser verificada, também, de certo modo, nos romances contemporâneos analisados. Nesses casos, como na literatura herculaniana, a figuração do mouro parece deslocar-se para a função de parâmetro significativo e revelador de novas perspectivas referentes ao contexto interno.

Tal tipo de formulação encontra respaldo em considerações elaboradas pelo próprio Alexandre Herculano, em sua História de Portugal. Além da discussão quase técnica sobre o fazer histórico e os diversos falseamentos ocorridos nos textos historiográficos referentes à ocupação árabe, Herculano ressalta, ainda, a importância de se pensar o invasor para se refletir sobre a própria imanência cultural: 
As relações amigáveis, que tão freqüentemente se estabelecem entre os chefes cristãos e muçulmanos, as usanças, os costumes e ainda as instituições que têm passado de uma sociedade para outra mostramnos que, apesar da oposição das crenças, da emulação do domínio, dos rios de sangue vertido, as duas raças se modificaram ao contato uma da outra, e que no estudo da posterior história de qualquer delas é necessário não esquecer a ação da sociedade rival para avaliar e entender devidamente as perspectivas condições de existência. (HERCULANO, s.d., p.18)

É notável a similaridade entre a perspectiva de Alexandre Herculano, apresentada no excerto acima, extraído de sua obra historiográfica, e a seguinte reflexão, bem mais recente, tecida em um contexto no qual os estudos culturais já se colocavam de forma sistemática:

Como foi observado por Melville J. Herskovits, antropólogo americano, foi preciso esperar os estudos sobre os fenômenos da "aculturação" para compreender melhor os mecanismos da cultura: "Quando as tradições estão em conflito, os reajustes no interior de uma cultura mostram a maneira como os elementos da cultura se ligam uns aos outros e como funciona o todo" (1937, p.263) (CUCHE, 2002, p.110)

Como vimos, a introdução de um "elemento bárbaro", o mouro, em vários textos literários aqui apresentados, desencadeou, de fato, uma nova possibilidade de reflexão sobre o que, a princípio, seria considerado o todo civilizado.

Uma terceira afirmação dessa perspectiva, que ressalta a importância de se pensar o elemento externo, bárbaro, para se entender melhor a cultura de origem, tida como civilizada, pode ser identificada em Friedrich Nietzsche, nesse caso, porém, do ponto de vista filosófico. De fato, para se pensar a civilização, entendida como um padrão moralista e decadente, Nietzsche, em sua obra de juventude, $O$ Nascimento da tragédia, e também na Genealogia da moral, traz à tona o componente bárbaro, ou, para definir a arte plástica, comedida e apolínea, o filólogo abarca a embriaguez e a desmedida dionisíacas. Assim, é através da intervenção do elemento estrangeiro que o 
filósofo alemão propõe sua reflexão crítica sobre a ordem, a civilização, a moral.

Retomando, então, o âmbito português, no qual foram elaboradas as obras literárias aqui abarcadas, verificamos a existência de um contexto bastante interessante para se pensar as questões apresentadas acima. O imaginário lusitano, configurado desde as suas raízes romanas, vem se confrontando com a problemática da alteridade, emergente de toda uma história de invasões, conquistas e descobertas, e que ainda, na atualidade, tenta definir o seu lugar em relação ao restante da Europa. Eduardo Lourenço diz que foi, exatamente, no início do século XIX, - época em que Herculano produziu boa parte de sua obra, portanto, - que Portugal, ao sair da Revolução Liberal, percebe seu alheamento em relação à Europa, voltando-se, então, para o seu passado em busca de paradigmas para o futuro:

É então que se dá conta até que ponto a sua situação é singular. E dessa singularidade faz parte o estranhíssimo fenômeno, mais do que paradoxal, de ter sido durante séculos uma nação que viveu e se viveu simbolicamente como uma ilha, sendo ao mesmo tempo um povo que desde os séculos XV e XVI se instalara no papel de descobridor e colonizador, em terras de África, do Oriente e do Brasil. (LOURENÇO, 1999, p.95)

Ou seja, ao mesmo tempo em que Portugal se voltava para fora, na construção de um império ultramarino, ele também precisava se ocupar com o islamismo sempre presente e ameaçador, e essas duas preocupações em relação "ao outro", que deveria ser dominado, acabaram por aliená-lo do processo civilizatório europeu. Lourenço ressalta o isolamento de Portugal até mesmo em relação a sua vizinha ibérica, a Espanha, pois enquanto esta, durante seu domínio político sobre Portugal no XVII século, teria assimilado a cultura lusitana, "Portugal, consciente ou inconscientemente, reflui para si mesmo, torna-se de ilha imperial gloriosa em ilha perdida na qual espera a ressurreição do seu passado [...]” (LOURENÇO, 1999, p.97). 
O sociólogo Boaventura de Sousa Santos, na análise que faz sobre Portugal, comenta que este país "é considerado [...] exótico, idiossincrático. Desconhecimento e exotismo são, pois, temas recorrentes quando se trata de propor uma apreciação global do país e do seu povo.” (SANTOS, 1994, p.49). De fato, uma questão incomodamente persistente ao longo da história lusitana refere-se ao seu descompasso civilizacional em relação à "Europa além-Pirineus" (LOURENÇO, 2001, p.42). Nesse contexto, considerando-se que o termo bárbaro não só se opõe a civilizado como, ainda, se aproxima dos termos exótico, primitivo e selvagem, poder-se-ia reconhecer na própria cultura portuguesa traços de uma constituição amplamente identificada como bárbara.

Referindo-se à época da experiência colonial portuguesa, Boaventura Santos atenta, também, para o fato de Portugal ocupar um lugar ambíguo em relação ao restante da Europa e às suas colônias. Segundo o autor, ao mesmo tempo em que é percebido como país estranho aos padrões culturais europeus, Portugal depara-se, também, com os hábitos exóticos dos povos colonizados, divergentes de seus próprios modelos civilizacionais, como se pode acompanhar abaixo:

Portugal foi o único país colonizador a ser considerado por outros países colonizadores como um país nativo ou selvagem. Ao mesmo tempo que os nossos [de Portugal] viajantes diplomatas e militares descreviam os curiosos hábitos e modos de vida dos povos selvagens com quem tomavam contacto no processo de construção do império, viajantes diplomatas e militares da Inglaterra ou da França descreviam, ora com curiosidade, ora com desdém, os hábitos e modos de vida dos portugueses, para eles tão estranhos ao ponto de parecerem pouco menos que selvagens. (SANTOS, 1994, p.59)

Distinguimos, de fato, em Portugal, um enquadramento privilegiado para se pensar a figuração do mouro, e os sentidos de alteridade e barbárie aí implicados, devido a sua condição peculiar de país que se percebe como civilizado em oposição aos "bárbaros invasores e colonizados", ao mesmo tempo em que é considerado exótico e 
selvagem aos olhos de outros países europeus. E, conforme sugerido anteriormente, a representação do mouro nas obras literárias analisadas corresponde, de fato, às peculiaridades concernentes ao contexto histórico português. Ou seja, a presença desse elemento estrangeiro e, por isso, também, bárbaro, na trama narrativa, evidencia principalmente reflexões de caráter endógeno.

Percebe-se, ainda, que em um mesmo autor, Alexandre Herculano, cuja obra volta-se predominantemente para o período medieval, no qual se deu a ocupação moura em Portugal, é possível acompanhar diferentes figurações desses povos. Essa fluidez identificada na concepção literária dos mouros parece, mesmo, justificar-se pela ausência de um repertório factual sobre sua ocupação em Portugal e uma superabundância de elaborações fantasiosas referentes a esses povos.

Em António José Saraiva podemos encontrar uma afirmação que além de corroborar essa hipótese, propõe, ainda, uma justificativa para a ausência de dados mais consistentes sobre o assunto: "No fundo estamos mal informados sobre o papel dos mouros na formação da sociedade, porque sendo a "Reconquista" uma guerra santa, a memória dos vencidos foi violentamente abolida e todos os sinais dela demolidos." (SARAIVA, 1991). Saraiva apresenta, também, um questionamento sobre o alcance do âmbito de atuação simbólico, referente à permanência da cultura árabe no interior da lusitana: "Mas em que medida ficou a presença deles, embora invisível e subterrânea, como a das mouras encantadas?" (SARAIVA, 1991).

Conforme foi visto, em muitos casos, a retratação dos caracteres mouros assume, realmente, uma dimensão lendária, que se distancia dos fatos históricos. E, justamente, esse distanciamento em relação ao contexto factual parece ter viabilizado a dimensão mítica permanente, já apontada por Alexandre Parafita, adquirida por esses 
elementos no imaginário ibérico.

No conjunto da obra literária de Alexandre Herculano, poderíamos depreender uma vertente associada ao componente lendário, encontrada nas Lendas e Narrativas, e outra, na qual se distingue um maior comprometimento com os fatos historiográficos, verificada em Eurico, o presbitero, O Bobo e O Monge de Cister (com exceção de uma personagem isolada, com pequena participação na trama: Zilá que, conforme comentamos, evocaria as lendas das mouras encantadas). Assim, é, principalmente, nas Lendas herculanianas, que se identifica, em alguma medida, o imaginário popular relativo aos mouros, particularmente, no que se refere aos feitos heróicos e fantasiosos das lutas entre cristãos e muçulmanos.

Já nos romances contemporâneos abordados, embora não ocorra uma figuração diretamente correspondente àquela mitologia dos mouros, apresentada por Alexandre Parafita, parece delinearem-se expressões contemporâneas desse imaginário. O inusitado trânsito entre o contexto da conquista bélica territorial para o âmbito amoroso, motivador de diversas lendas relativas ao encantamento passional, principalmente, entre mouras e cristãos, encontra ressonância nas obras de Mário de Carvalho e José Saramago. Em ambos os autores verificamos que a presença do mouro na narrativa, viabiliza, ainda que subliminarmente, reflexões relativas à alteridade, que desencadeiam, em última instância, o discurso amoroso. Há, certamente, afinidades e espelhamentos entre o imaginário referente ao mouro, constituído como alteridade inapreensível, e as relações de estranhamento e incomunicabilidade estabelecidas entre os pares amorosos de História do cerco de Lisboa e Um deus passeando pela brisa da tarde.

Tal perspectiva parece afinar-se com as diversas proposições referentes à 
permeabilidade entre história e ficção, predominantes na literatura histórica contemporânea, na medida em que ambas se sustentam em representações narrativas do passado. É de Linda Hutcheon a seguinte afirmação:

O que a escrita pós-moderna da história e da literatura nos ensinou é que a ficção e a história são discursos, que ambas constituem sistemas de significação pelos quais damos sentido ao passado (aplicações da imaginação modeladora e organizadora)". (HUTCHEON, 1991, 122).

Tanto a escolha dos fatos como, também, a forma discursiva, pela qual eles são organizados para se elaborar a obra literária ou a historiográfica, estarão, de algum modo, relacionados ao padrão de pensamento vigente. Paul Veyne, na citação abaixo, problematiza a relação entre a história e os fatos históricos:

[...] os fatos não existem"; isto é, não existem em estado isolado, exceto por abstração; concretamente, existem apenas sob o conceito que os informa. $\mathrm{Ou}$, se preferirem, a História existe apenas em relação às questões que nós lhe formulamos. Materialmente, a História é escrita com fatos; formalmente, com uma problemática e conceitos. (VEYNE, 1990, p.6)

E, seguindo uma linha de raciocínio semelhante, Linda Hutcheon elabora a seguinte constatação sobre a presença do passado na ficção, considerada pós-moderna: "A ficção pós-moderna sugere que reescrever ou reapresentar o passado na ficção e na história é - em ambos os casos - revelá-lo ao presente, impedi-lo de ser conclusivo e teleológico". (HUTCHEON, 1991, p.147).

Assim, não apenas a história e a literatura confluem no âmbito narrativo, mas, ainda, a "ficção histórica pós-moderna", particularmente, promoveria a revisão, atualização ou reapresentação do passado. Desse modo, parece-nos, de fato, coerente que as obras contemporâneas, valendo-se de tais condições menos segmentadas e rígidas de concepção da história e da literatura, possam encontrar, nas nuances 
históricas de um passado lendário e mítico, elementos significativos para sua constituição narrativa.

Se em algumas das narrativas componentes das Lendas de Alexandre Herculano, ou mesmo naquela breve referência à obra de Almeida Garrett, "Dona Branca”, acompanhamos um diálogo direto com as tradições populares referentes aos mouros, nos romances contemporâneos, entretanto, reminiscências de tal imaginário, atuam de forma mais simbólica na trama narrativa. Como dissemos, as obras de Herculano apresentam-se cindidas entre a perspectiva histórica e a folclórica, prevalecendo, de fato, na maioria das narrativas, a figuração do mouro vinculada aos aspectos historiográficos. Já os romances de José Saramago e Mário de Carvalho partindo da perspectiva histórica, referente à presença moura em Portugal ou na Lusitânia, alcançam representações mais abstratas, vinculadas ao sentido de alteridade, que expressam, por fim, relações amorosas ou passionais. Maria Alzira Seixo ressalta, abaixo, uma perspectiva semelhante, mas abordando a história, de modo geral, na História do cerco de Lisboa:

É certo que este é, nos romances de Saramago, aquele onde o discurso da História mais lugar ocupa, tendo, no entanto, uma ocupação diegética reduzidíssima, quase inexistente, tornada símbolo ou pretexto indicial de formulação da intriga. Isto é: o que efetivamente acontece, no universo ficcional, é o namoro de Raimundo e Maria Sara [...] (SEIXO, 1999, p.75)

Poderíamos identificar, então, nas configurações dos dois romances contemporâneos referidos, a confluência dos aspectos historiográficos referentes aos mouros com o universo lendário e mítico, relativo a esses povos. A redução do componente histórico parece viabilizar a expressão desse outro contexto concernente ao imaginário amoroso entre cristãos e mouros, prevalente no âmbito lendário. Mas, outro 
elemento essencial para o estabelecimento de tal trânsito, que vai do âmbito histórico para o mítico amoroso, constitui-se da complexidade dos aspectos discursivos nos romances de Saramago e Carvalho. De fato, a grande significância discursiva, tão ressaltada nas metaficções historiográficas, pode ser também aqui verificada, na medida em que os próprios fatos narrados são absorvidos e transformados em estruturas narrativas. Assim, a estrutura de cerco, extraída da presença moura em História do cerco de Lisboa, desloca-se para o âmbito discursivo, viabilizando uma narrativa que contempla o contexto amoroso, através da tensão estabelecida entre sitiado e sitiante. Também em Um deus passeando pela brisa da tarde, a apropriação do sentido de alteridade apreendido da presença dos invasores mouros em Tarcisis, contamina e enforma a narrativa memorial de Lúcio, que constitui um discurso de estranhamento e incompreensão frente aos fatos abordados. E, como foi visto, o sentido de alteridade mais ameaçador e invasivo, pode ser identificado no discurso amoroso referente à Iunia Cantaber. 


\section{REFERÊNCIAS}

AFONSO, Graça; MATOS, Álvaro Costa. Alexandre Herculano: um pensamento "poliédrico". Colóquio Comemorativo dos 120 anos de sua morte (1877 - 1997). Coleção: Actas \& Colóquios da Hemeroteca, $\mathrm{n}^{\circ}$ 3. Bibliotecas Municipais de Lisboa: Lisboa, 2005.

ALBUQUERQUE, M. Fátima. A obra novelístiva de Alexandre Herculano. In: Actas do COLÓQUIO ALEXANDRE HERCULANO LIBERALISMO E ROMANTISMO. Escola Superior de Educação de Santarém: Santarém,1999.

ALENCAR, José de. O Guarani. Apresentação e notas Eduardo Vieira Martins. São Paulo: Ateliê Editorial, 2000.

ALVES, Adalberto. Portugal: Ecos de um Passado Árabe. Lisboa: Instituto Camões, 1999.

AURÉLIO, Marco. Pensamentos. Versão de João Maia. Lisboa: Editorial Verbo, 1971.

BARREIROS, António José. História da Literatura Portuguesa. Braga: Editora Pax, 1989.

BEIRANTE, Cândido; CUSTÓDIO, Jorge. Alexandre Herculano. Secretaria do Estado da Cultura. Lisboa, 1977.

BENJAMIN, Walter. Sobre o conceito de História. Tradução de Sérgio Paulo Rouanet. In: Obras escolhidas. Magia e técnica, arte e política. São Paulo: Editora Brasiliense, 1985. p.222 - 232.

BIGNOTTO, Newton. Tolerância e diferença. In: NOVAES, Adauto (Org.). Civilização e Bárbarie. São Paulo: Companhia das Letras, 2004. p. 61- 79.

BOXER, C.R. Relações Raciais no Império Colonial Português: 1415 - 1825. Rio de Janeiro: Tempo brasileiro, 1967.

BRAGA, Teófilo. História da Literatura Portuguesa: O Romantismo, v.V. Lisboa: Publicações Europa-América, 1977.

BRAGA, Teófilo. O povo português nos seus costumes, crenças e tradições. Lisboa: Dom Quixote, 1995.

BUESCU, Helena Carvalhão. 2005. A obra literária de Alexandre Herculano. In: AFONSO, Graça; MATOS, Álvaro Costa. Alexandre Herculano: um pensamento "poliédrico". Colóquio Comemorativo dos 120 anos de sua morte (1877 - 1997). Coleção : Actas \& Colóquios da Hemeroteca, $n^{\circ} 3$. Bibliotecas Municipais de Lisboa: Lisboa, 2005. p.151 - 162. 
BIBLOS Enciclopédia VERBO das Literaturas de Língua Portuguesa (vol. 3). Lisboa: Verbo, s.d. p.25 - 29.

CAMÕES, Luís de. Os Lusíadas. São Paulo: Luso-Brasil, s.d.

CARDOSO, Margarida. Alexandre Herculano. In: MACHADO, Álvaro Manuel et al. História da Literatura Portuguesa. Lisboa: Publicações Alfa, 2003. p.141 - 185.

CASTRO, Francisco Lyon (Ed.). História da Literatura Portuguesa. Lisboa: Publicações Alfa, 2003.

CARVALHO, Mário de. Um deus passeando pela brisa da tarde. Lisboa: Editorial Caminho, 1997.

CHAUI, Marilena. Fundamentalismo religioso: a questão do poder teológico-político. In: NOVAES, Adauto (Org.). Civilização e Bárbarie. São Paulo: Companhia das Letras, 2004.

CIDADE, Hernâni. Alexandre Herculano. In: SIMÕES, João Gaspar. Perspectiva da Literatura Portuguesa do século XIX. Lisboa: Edições Ática, 1947. p. 87-117.

COLÓQUIO ALEXANDRE HERCULANO: LIBERALISMO E ROMANTISMO. Escola Superior de Educação de Santarém. 1999, Santarém.

CUCHE, Denys. A noção de cultura nas ciências sociais. Edusc: Bauru, 2002.

DICIONÁRIO do Romantismo Literário Português. Coordenação de Helena Carvalhão Buescu. Lisboa: Caminho, 1997.

DICIONÁRIO de Literatura Portuguesa. Organização e direção Álvaro Manuel de Machado. Lisboa: Editorial Presença, 1996.

DINIS, Júlio. Os fidalgos da casa mourisca. In: Obras de Júlio Dinis, vol. I. Porto: Lello \& Irmaos, 19--, p.897 - 1229.

DOMINGUES, José Garcia. Presença árabe no Algarve. In: Islão e Arabismo em terras lusitanas. Publicações da Universidade de Évora: Évora, 1986.

FARINHA, António Dias. A civilização árabe na obra de Herculano. Separata de Alexandre Herculano a luz do nosso tempo. Academia Portuguesa de História: Lisboa, 1977.

FERREIRA, Alberto. Perspectiva do Romantismo Português(1834 - 1865). Lisboa: Edições 70, 1971.

FRANÇA, José-Augusto. O Romantismo em Portugal: estudos de fatos socioculturais. Lisboa: Livros Horizonte, 1993. 
FRANCHETTI, Paulo. Prefácio. In: HERCULANO, Alexandre. $O$ Bobo. São Paulo: Editora Ática, 1997.

FREYRE, Gilberto. Casa-grande \& senzala. São Paulo: Editora Record, 2000.

GARRETT, Almeida. O Arco de Sant'Ana. Lisboa: Editorial Verbo, s.d.

GARRETT, Almeida. Dona Branca. In: Obras de Almeida Garrett (vol.II). Porto: Lello \& Irmãos, 1963.

GIL, Ana Cristina Correia. O romance histórico na obra de Herculano: estratégias narrativas ao serviço de um programa pedagógico. In: COLÓQUIO ALEXANDRE HERCULANO: LIBERALISMO E ROMANTISMO. Escola Superior de Educação de Santarém. 1999, Santarém. p.77 - 85.

HERCULANO, Alexandre. Destruição de Áuria. In: MONTEIRO, Ofélia Paiva. Um conto desconhecido de Herculano: "Destruição de Áuria". Faculdade de Letras da Universidade de Coimbra: Coimbra, 1973

HERCULANO, Alexandre. Eurico, o presbittero. São Paulo: Editora Ática, 1996.

HERCULANO, Alexandre. Eurico, o presbitero. In: Obras Completas de Alexandre Herculano. Introdução e revisão de Vitorino Nemésio. Amadora: Livraria Bertrand, 1979. p. VII - LV.

HERCULANO, Alexandre. História de Portugal: desde o começo da monarchia até o fim do reinado de Affonso III. Vol II, Lisboa: Livraria Bertrand, s.d. p. 7 - 132.

HERCULANO, Alexandre. Lendas e Narrativas. Amadora: Bertrand, 19--.

HERCULANO, Alexandre. Lendas e Narrativas. In: Obras Completas de Alexandre Herculano. Introdução e revisão de Vitorino Nemésio. Amadora: Livraria Bertrand, 1979.

HERCULANO, Alexandre. Lendas e Narrativas. In: Obras Completas de Alexandre Herculano. Introdução e revisão de Vitorino Nemésio. Amadora: Livraria Bertrand, 1974. p. VII - XXI.

HERCULANO, Alexandre. O Bobo. In: Obras Completas de Alexandre Herculano. Introdução e revisão de Vitorino Nemésio. Amadora: Livraria Bertrand, 1972. p. VII XXII.

HERCULANO, Alexandre. O Bobo. São Paulo: Editora Ática, 1997.

HERCULANO, Alexandre. O Monge de Cister. In: Obras (vol. I.). São Paulo: Edição Saraiva, 1959. 
HERCULANO, Alexandre. O Monge de Cister. Obras Completas de Alexandre Herculano. Introdução e revisão de Vitorino Nemésio. Amadora: Livraria Bertrand, 1977. p. VII - XXIII.

HERCULANO, Alexandre. Obras (vol. I.). São Paulo: Edição Saraiva, 1959.

HERCULANO, Alexandre. Obras Completas de Alexandre Herculano (tomo II). Introdução e revisão de Vitorino Nemésio. : Amadora: Livraria Bertrand, 1977. p. VII XXIII.

HERCULANO, Alexandre. Obras Completas de Alexandre Herculano. Introdução e revisão de Vitorino Nemésio. Amadora: Livraria Bertrand, 1979.

HUTCHEON, Linda. Poética do pós-modernismo: história, teoria, ficção. Rio de Janeiro: Imago, 1991.

LALANDE, André. Vocabulário Técnico e Crítico da Filosofia. São Paulo: Martins Fontes, 1999.

LEVI, Primo. É isto um homem? Rio de Janeiro: Rocco, 1988.

LOPES, David. Portugal contra os mouros. Lisboa: Noções de tudo, 193-.

LOURENÇO, Eduardo. Mitologia da saudade: seguido de Portugal como destino. São Paulo: Companhia das Letras, 1999.

LOURENÇO, Eduardo. A nau de Ícaro. São Paulo: Companhia das Letras, 2001.

MACHADO, Álvaro Manuel et al. História da Literatura Portuguesa. Lisboa: Publicações Alfa, 2003.

MARINHO, Maria de Fátima. O Romance Histórico em Portugal. Porto: Campos das Letras, 1999.

MARQUES, Gentil. Lendas de Portugal: lendas de mouras e mouros. Vol.3. Lisboa: Âncora Editora, 1999.

MARTINS, Oliveira. As raças humanas e a civilização primitiva. Vol. I. Lisboa: Guimarães Editores, 1955.

MARTINS, Oliveira. História de Portugal. : Lisboa: Guimarães Editores, 1972.

MONTEIRO, Ofélia Paiva. Romantismo e Romantismos. In: CASTRO, Francisco Lyon (Ed.). História da Literatura Portuguesa. Lisboa: Publicações Alfa, 2003. p. 9 - 43.

MONTEIRO, Ofélia Paiva. Um conto desconhecido de Herculano: "Destruição de Áuria”. Faculdade de Letras da Universidade de Coimbra: Coimbra, 1973. 
MONTEIRO, Ofélia. In: BIBLOS Enciclopédia VERBO das Literaturas de Língua Portuguesa (vol. 3). Lisboa: Verbo, s.d. p.25 - 29.

MOREIRA, Ana Rita Gaspar. Árabes e Nação na periferia da Europa: de Alexandre Herculano a David Lopes. 20005. Tese (Mestrado em Ciências Sociais) - Instituto de Ciências Sociais da Universidade de Lisboa, Lisboa, 2005.

MOURA, Carlos Alberto Ribeiro de. Nietzsche: civilização e cultura. São Paulo: Martins Fontes, 2005.

NEMÉSIO, Vitorino. Introdução. In: HERCULANO, Alexandre. Eurico, o presbítero. Obras Completas de Alexandre Herculano. Introdução e revisão de Vitorino Nemésio. : Amadora: Livraria Bertrand, 1979. p. VII - LV.

NEMÉSIO, Vitorino. Introdução. In: HERCULANO, Alexandre. O Bobo. Obras Completas de Alexandre Herculano. Introdução e revisão de Vitorino Nemésio. Amadora: Livraria Bertrand, 1972. p. VII - XXII.

NEMÉSIO, Vitorino. Introdução. In: HERCULANO, Alexandre. O Monge de Cister. Obras Completas de Alexandre Herculano. Introdução e revisão de Vitorino Nemésio. Amadora: Livraria Bertrand, 1977. p. VII - XXIII.

NEMÉSIO, Vitorino. Prefácio. In: HERCULANO, Alexandre. Lendas e Narrativas. Obras Completas de Alexandre Herculano. Introdução e revisão de Vitorino Nemésio. Amadora: Livraria Bertrand, 1974. p. VII - XXI.

NIETZSCHE, Friedrich Wilhelm. O nascimento da tragédia ou helenismo $e$ pessimismo. Tradução, notas e posfácio de Jacó Guinsburg. São Paulo: Companhia das Letras, 2000.

NIETZSCHE, Friedrich Wilhelm. Genealogia da moral: uma polêmica. Tradução, notas e posfácio de Paulo César de Souza. São Paulo: Companhia das Letras, 2005.

NOVAES, Adauto (Org.). Civilização e Bárbarie. São Paulo: Companhia das Letras, 2004.

OLIVEIRA, Paulo Motta. Alexandre Herculano: malhas da história, armadilhas da ficção. In: BOËCHAT, Maria Cecília Bruzzi; OLIVEIRA, Paulo Motta; OLIVEIRA, Silvana Maria Pessôa (Org.). Romance Histórico: recorrências e transformações. FALE/UFMG: Belo Horizonte, 2000. p.129-149.

OLIVEIRA, Maria Lúcia Wiltshire. Costuras, soldagens, remendos: o projeto pósmodernista na História do cerco de Lisboa, de José Saramago. In: OLIVEIRA, Paulo Motta. Alexandre Herculano: malhas da história, armadilhas da ficção. In: BOËCHAT, Maria Cecília Bruzzi; OLIVEIRA, Paulo Motta; OLIVEIRA, Silvana Maria Pessôa 
(Org.). Romance Histórico: recorrências e transformações. FALE/UFMG: Belo Horizonte, 2000.

PARAFITA, Alexandre. A Mitologia dos Mouros. Canelas: Gailivro, 2006.

PEDROSO, Z. Consiglieri. As Grandes Épocas da História Universal. Porto: Livraria Civilização, 1883.

PEREIRA, Capelo B. In: DICIONÁRIO do Romantismo Literário Português. Coordenação de Helena Carvalhão Buescu. Lisboa: Caminho, 1997. p. 221 - 230.

RODRIGUES, Ernesto. Torre de Dona Chama. Lisboa: Editorial Notícias, s.d.

SARAIVA, António José. A cultura em Portugal. Teoria e História. volI. Introdução geral à Cultura Portuguesa. Lisboa: Gradiva, 1996.

SARAIVA, António José. A cultura em Portugal. Teoria e História. volII. Primeira Época: a formação. Lisboa: Gradiva, 1991.

SANTOS, Boaventura de Sousa. Pela mão de Alice. Porto: Edições Afrontamento, 1994.

SARAMAGO, José. História do cerco de Lisboa. São Paulo: Companhia das Letras: 2004.

SEIXO, Maria Alzira. Lugares da ficção em José Saramago. Lisboa: Imprensa Nacional - Casa da Moeda, 1999.

SILVA, Maria Cardeira da. O sentido dos árabes no nosso sentido. Dos estudos sobre árabes e sobre muçulmanos em Portugal. In: Análise Social, vol. XXXIX, n.173, 2005. p.781- 806 .

SIMÕES, João Gaspar. História do Romance Português. Vol.II. Lisboa: Estúdios Cor:, 1969.

SIMÕES, João Gaspar (Org). Perspectiva da Literatura Portuguesa do século XIX. volI, Lisboa: Edições Ática, 1947.

SOBREIRA, Luís Alexandre Rodrigues. Uma imagem do campo literário português no período romântico: contributo para a história da literatura produzida em Portugal entre 1840 e 1860. Dissertação. (Mestrado em Literatura Portuguesa). Faculdade de Letras da Universidade de Lisboa. Lisboa, 1998.

VEYNE, Paul (Org.). História da vida privada: Do Império Romano ao Ano Mil. São Paulo: Companhia das Letras, 1990. p.6 - 100.

WOLFF, Francis. Quem é bárbaro? In: NOVAES, Adauto (Org.). Civilização e Bárbarie. São Paulo: Companhia das Letras, 2004. p.19 - 43. 


\section{APÊNDICE - Síntese de lendas}

Síntese de algumas lendas extraídas da obra de Gentil Marques: Lendas de Portugal: lendas de mouras e mouros (1999)

1 - Lenda da serra do Nó - (região do Minho) Um rei mouro jovem e rico, Abakir, se apaixona e acaba por conquistar uma pastora moura. Mas a chegada dos cristãos em suas terras ocasiona a retirada de toda a população moura, com exceção de Abakir e sua esposa que, em atitude heróica, decidem permanecer no castelo. E quando os inimigos se aproximam, de fato, o rei mouro valendo-se da leitura do Alcorão e do uso de magia faz com que o castelo com seus dois habitantes desapareçam. Diz-se, então, ocorrer, a partir daí, a aparição, em noites de luar, da princesa moura da serra do nó, que leva a perdição todos aqueles que a seguirem.

2 - Lenda da flor dos montes - passa-se na região do Minho - conta a história de Maria Clara, chamada por todos de "flor dos montes" e que sofria por ser muito pobre e não ser bem aceita pela família de seu noivo. Então, faz um acordo com uma moura encantada, que lhe apareceu no alto de um penedo, para tornar-se rica. Mas ela acaba quebrando o juramento feito a moura de não contar a ninguém sobre o pacto e antes mesmo de levar um fermento que havia prometido à moura em troca das riquezas Maria Clara revela sua existência. Além de não receber o tesouro a moça quase perde o amor de seu noivo que, entretanto, acaba por perdoá-la e a lenda tem um final feliz.

3 - Lenda dos sete ais - região de Sintra - conta a história de D. Mendo de Paiva, um dos principais cavaleiros de D. Afonso Henriques que, depois da tomada do castelo de 
Sintra, se apaixona e casa-se com uma princesa moura, Anasir, que habitava o lugar. Mas um dia o noivo mouro da moça aparece para vingar-se da traição sofrida. Cumprindo uma profecia feita por uma bruxa, quando Anasir nasceu, esta morre, assassinada pelo antigo noivo, a sétima vez que pronuncia o grito "ai”. Ressalta-se aí as qualidades heróicas de D. Mendo de Paiva e o grande amor existente entre ele e a princesa moura Anasir e, por outro lado, as atitudes covardes e indignas de Aben-Abed, o noivo mouro que após abandonar Anasir acaba voltando para matá-la devido ao seu ciúme. Ao fim, como vingança, D. Menedo Paiva torna-se um dos mais terríveis caçadores de mouros de sua época.

4 - Lenda do castelo de Alcoutim - (distrito de Faro) também nessa lenda, uma bela moura Zuleima, apaixona-se por um cavaleiro cristão, D. Rui Gomes, depois que seu namorado mouro fugiu do confronto com os cristãos. D. Rui e Zuleima viveram, então, algum tempo juntos e felizes até que um dia o namorado mouro de Zuleima, Ali Hassam, volta e sorrateiramente assassina D. Rui e rapta a moura. Logo após esses evento, os cavaleiros cristãos perseguem e matam Ali Hassam e também, sem o saber, Zuleima. Fecha-se a lenda contando das aparições da moura, perto do castelo de Alcoutim, chorando pelo cavaleiro cristão, D. Rui Gomes.

5 - Lenda da torre de Moncorvo - tem como fundo o ano de 1062 e a tentativa de expulsão dos mouros por D. Fernando I, rei de Leão. Apresenta a história de D. Mem Corvo, um fidalgo muito corajoso, que lutava contra os mouros e que acolhe e se apaixona pela moura Zaida, que estava sendo perseguida por outro cristão. Ela muda de nome a pedido de D. Mem Corvo e passa a ter um nome cristão: Joana. Mas, quando 
descobre que esse era o nome da antiga namorada de infância de seu amado, Zaida se entristece e acaba por adoecer e morrer devido ao ciúmes que sentia. Muito entristecido com a morte da moura cristianizada, D. Mem Corvo que anteriormente mandara construir uma torre nas terras vizinhas para livrar-se do mal causado pelo cultivo de linho, que fizera com que Zaida adoecesse, decide, então, mudar-se pra lá quando a construção ficou pronta. Constitui-se uma população nos arredores da torre, transformando-se logo em uma vila que ao longo do tempo passou a se chamar Torre de Moncorvo.

6 - Lenda da moura de Albufeira - (região do Algarve) - narra a história da moura Alina, filha do Alcaide, que, embora estivesse prometida ao mouro Aben Farah, um prisioneiro de honra, é conquistada pelo rei D. Afonso III. O rei liberta o pai e o antigo namorado de Alina e tem com ela um filho. Mas, uma vez, ao retornar de uma de suas lutas contra os mouros ou contra Castela, o rei encontra Alina muito aflita e pálida. Ela então revelou ao marido que um animal estranho, parecendo um misto de carneiro e cachorro, andava rondando os seus aposentos. A moura explica ainda que suspeita que o animal seria Aben Farah que estaria encantado e teria o intuito de vingar-se de ambos. D. Afonso, então, promete à moura que ela e seu filho passariam a segui-lo sempre em suas viagens e que seu valido D. João iria guardá-los impedindo que qualquer mal hes atingisse. Assim, termina a lenda da moura encontrada no castelo de Albuferia.

7 - Lenda do cântico do mouro - essa lenda refere-se a um mouro muito belo e dissoluto, alcaide-mor do castelo de Alcobaça, que teria ficado encantado no interior de seu palácio e de Jacinta, uma menina muito corajosa, que vivia com seu pai e avó. Um 
dia o pai de Jacinta passa mal e, apesar dos temores da avó, ela decide ir buscar ajuda em Alcobaça, sendo necessário para isso passar pelo castelo do mouro encantado já de noite. A avó então lhe dá uma medalha de São Bernardo para protegê-la do cântico sedutor do mouro. Jacinta ao passar pelo castelo sentiu-se, de fato, muito atraída quando ouviu o maravilhoso canto do mouro, mas proferindo a oração a São Bernardo ouviu uma voz dizendo-lhe que havia sido salva pela fé. Ela conseguiu, então, resistir e continuar o seu caminho.

8 - Lenda do bolo branco - (Silves - cidade do Algarve) a lenda narra os fatos ocorridos com Diogo, um trabalhador muito corajoso, ao encontrar-se com a princesa moura encantada, que guardava o tesouro de seu pai, no castelo de Silves. Ele faz um acordo com a moura de levar para ela um bolo bem grande dividido em quatro partes em troca de todo o tesouro do rei. Mas, o pacto previa também que ninguém poderia saber de nada, e a mulher de Diogo inconformada com a atitude estranha do marido de confeitar tal bolo altas horas da noite decide parti-lo para ver se havia algo escondido no seu interior. Ao fazer isso ela percebe, horrorizada, que escorria sangue de dentro do bolo. Quando Diogo leva o bolo para a princesa, percebe que o cavalo em que ela estava montada tinha uma das patas amputadas e sangrando. Ao cortar o pedaço do bolo sua mulher cortara, na verdade, a perna do animal no qual a moura pretendia fugir. A princesa moura, então, muito aborrecida com o ocorrido diz que Diogo não cumprira o pacto e que não ganharia o tesouro, mas deu-lhe um cinto para entregar a sua esposa. Diogo descobriu que o cinto era na verdade uma lâmina e que se tivesse entregado a sua mulher ela teria sido cortada ao meio. A moura continuou assim encantada e presa ao castelo de Silves. 
9 - Lenda da moura do Pontão - a lenda conta o ocorrido entre António, Belmira e Aninhas na noite da São João. Belmira quando criança ficou aleijada ao correr com medo da moura do Pontão. Ela gostava de António, mas sabia que ele era apaixonado por Aninhas. A moça, entretanto, sob a influência da mãe ficava dividida entre António e Vicente, que era um moço mais rico. Penalizada com a situação de António, Belmira decide procurar a moura, pois dizia-se que, na noite de São João, a moura do pontão colocava em uma manta passas que se transformavam em ouro, caso alguém conseguisse pegá-las sem acordá-la. Mas Belmira é encontrada morta e todos pensam que foi por ambição ou vaidade que ela tentou conseguir o tesouro da moura, apenas António se entristece, pois entende que foi para ajudá-lo que ela enfrentou tal perigo e morreu.

10 - Lenda do cristão cativo - (ano de 1267 - reino de D. Afonso III) - um homem de Penamacor, que lutava contra os mouros, vai, juntamente com sua filha, até a Capela de Sobreira pedir proteção à imagem de S. Domingos de Gusmão. Mas, ele acabou tornando-se um cativo dos mouros e foi levado para o norte da África. O mouro, seu carcereiro, passa a persegui-lo e, após várias agressões, finalmente, o encerra em uma arca para que ele não tivesse nenhuma possibilidade de fugir. Sua filha, então, desesperada com a falta de notícias do pai, reza a S. Domingos de Gusmão pedindo que a leve para o céu, mas que salve a vida de seu pai. O pedido é atendido e a arca, na qual o cristão estava preso é transportada, juntamente com o mouro, que estava deitado sobre ela, por uma mão invisível até Penamacor. Chegando aí o cristão perdoa o mouro e torna-se seu amigo, esclarecendo que fora essa a promessa feita a S. Domingos caso ele 
salvasse sua vida. Quando descobre que perdeu a filha ele fica muito entristecido e o mouro então passa a ser o seu grande amigo, e ambos tornam-se eremitas, vivendo o resto de suas vidas próximo à ermida de $\mathrm{S}$. Domingos de Gusmão e quando morreram foram enterrados lado a lado. 


\section{ANEXO 1}

\section{A DAMA PE-DE-CABRA}

Este dom Diego Lopez era muy boo monteyro, e estando huum dia em sa armada e atemdemdo quamdo verria o porco ouuyo cantar muyta alta voz huuma molher em çima de huuma pena: e el foy pera la e vioa seer muy fermosa e muy bem vistida, e namorousse logo della muy fortemente e preguntoulhe quem era: e ella lhe disse que era huuma molher de muito alto linhagem, e ell the disse que pois era molher d'alto linhagem que casaria com ella se ella quisesse, ca elle era senhor naquella terra toda: e ella lhe disse que o faria se lhe prometesse que numca sse santificasse, e elle lho outorgou, e ella foisse logo com elle. E esta dona era muy fermosa e muy bem feita em todo seu corpo saluamdo que auia huum pee forcado como pee de cabra. E viuerom gram tempo e ouueram dous filhos, e huum ouue nome Enheguez Guerra, e a outra foy molher e ouue nome dona. E quando comiam de suum dom Diego Lopez e sa molher assemtaua ell apar de ssy o filho, e ella assemtaua apar de ssy a filha da outra parte. E huum dia foy elle a seu monte e matou huum porco muy gramde e trouxeo pera sa casa, e poseo ante ssy hu sia comemdo com ssa molher e seus filhos: e lamçarom huum osso da mesa e veerom a pellejar huum alaão e huuma podemga sobrelle em tall maneyra que a podenga trauou ao alaão em a garganta e matouo. E dom Diego Lopes quamdo esto uyo teueo por millagre e synousse e disse «samta Maria vall, quem vio numca tall cousa!» E ssa molher quamdo o vyo assy sinar lamçou maão na filha e no filho, e dom Diego Lopez trauou do filho e nom lho quis leixar filhar: e ella rrecudio com a filha por huuma freesta do paaço e foysse pera as montanhas em guisa que a nom virom mais nem a filha.

Depois a cabo de tempo foy este dom Diego Lopez a fazer mall aos mouros, e premderomno e leuaromno pera Tolledo preso. E a seu filho Enheguez Guerra pesaua muito de ssa prisom, e veo fallar com os da terra per que maneyra o poderiam auer fora da prisom. E elles disserom que nom sabiam maneyra por que o podessem aver, saluamdo sse fosse aas montanhas e achasse sa madre, e que ella lhe daria como o tirasse. E ell foy alaa soo em çima de seu cauallo, e achoua em çima de huuma pena: e ella lhe disse «filho Enheguez Guerra, vem a mym ca bem sey eu ao que ueens:» e ell foy pera ella e ella lhe disse «veens a preguntar como tiraras teu padre da prisom.» Emtom chamou huum cauallo que amdaua solto pello momte que avia nome Pardallo e chamouo per seu nome: e ella meteo huum freo ao cauallo que tiinha, e disselhe que nom fezesse força pollo dessellar nem pollo desemfrear nem por lhe dar de comer nem de beuer nem de ferrar: e disselhe que este cauallo lhe duraria em toda sa vida, e que nunca emtraria em lide que nom vemçesse delle. E disselhe que caualgasse em elle e que o poria em Tolledo ante a porta hu jazia seu padre logo em esse dia, e que ante a porta hu o caualo o posesse que alli deçesse e que acharia seu padre estar em huum curral, e que o filhasse pella maão e fezesse que queria fallar com elle, que o fosse tirando comtra a porta hu estaua ho cauallo, e que desque alli fosse que cauallgasse em o cauallo e que posesse seu padre ante ssy e que ante 
noite seria em sa terra com seu padre: e assy foy. E depois a cabo de tempo morreo dom Diego Lopez e ficou a terra a seu filho dom Enheguez Guerra. 